Göttingen Series in Social and Cultural Anthropology

Ramzi Ben Amara

\title{
The Izala Movement in Nigeria
}

Genesis, Fragmentation and Revival

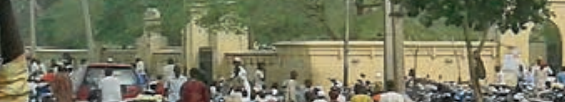

स. 3

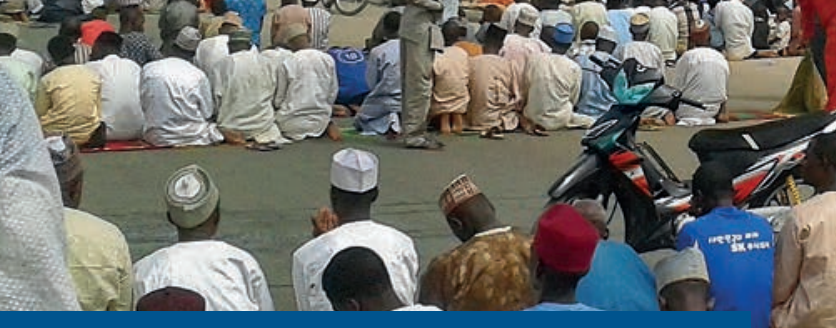

ats

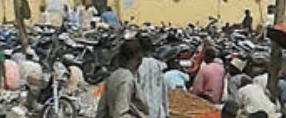

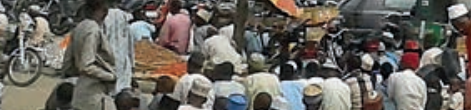

G Göttingen University Press 

Ramzi Ben Amara

The Izala Movement in Nigeria

This work is licensed under a Creative Commons Attribution-ShareAlike 4.0

International License.

(c) $\underset{\mathrm{BY}}{\mathrm{B}} \mathrm{SA}$ 
Published in 2020 by Göttingen University Press

as volume 18 in "Göttingen Series in Social and Cultural Anthropology"

This series is a continuation of "Göttinger Beiträge zur Ethnologie". 
Ramzi Ben Amara

The Izala Movement in Nigeria

Genesis, Fragmentation and Revival

Volume 18

Göttingen Series in Social and

Cultural Anthropology

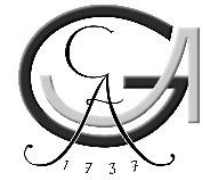

Göttingen University Press 2020 
Bibliographische Information der Deutschen Nationalbibliothek

Die Deutsche Nationalbibliothek verzeichnet diese Publikation in der Deutschen Nationalbibliographie; detaillierte bibliographische Daten sind im Internet über $<$ http://dnb.dnb.de> abrufbar.

"Göttingen Series in Social and Cultural Anthropology" Editors

Prof. Dr. Elfriede Hermann

Prof. Dr. Andrea Lauser

Prof. Dr. Roman Loimeier

Prof. Dr. Nikolaus Schareika

Institute of Social and Cultural Anthropology

Georg-August-Universität Göttingen

Theaterplatz 15

D-37073 Göttingen

This work is protected by German Intellectual Property Right Law.

It is also available as an Open Access version through the publisher's homepage and the Göttingen University Catalogue (GUK) (http://www.sub.uni-goettingen.de).

The license terms of the online version apply.

Setting and layout: Steffen Herrmann

Coverpicture: Friday prayer at the Kano central mosque,

Andrea Brigaglia, 2016

(C) 2020 Universitätsverlag Göttingen

http://univerlag.uni-goettingen.de

ISBN: 978-3-86395-460-4

DOI: https://doi.org/10.17875/gup2020-1329

eISSN: 2512-6881 
To my late father Hmida 



\section{Contents}

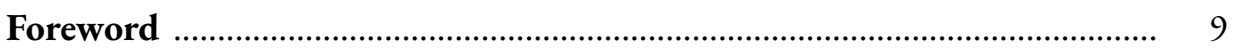

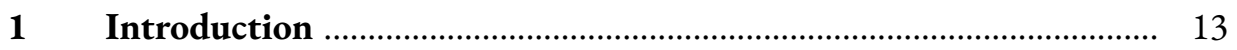

$1.1 \quad$ The scope of research ....................................................................... 16

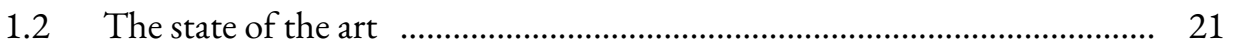

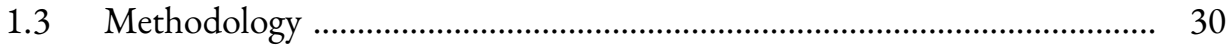

$1.4 \quad$ The theoretical framework ....................................................................... 33

2 Nigeria's religious landscape …………………................................. 45

2.1 Christianity in Nigeria ............................................................................ 45

2.2 The history of Islam in Nigeria ................................................................. 47

2.2.1 The Sufi brotherhoods ................................................................. 49

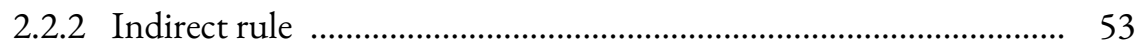

2.2.3 English law or Islamic law ............................................................ 57

2.2.4 Islam in Nigeria during the postcolonial era .................................. 60

2.2.5 The conflict between the Sufi brotherhoods ................................... 64

2.2.6 Sheikh Abubakar Gumi and his struggle against Sufism ............... 67

3 Reform Islam versus Sufism ............................................................ 75

3.1 What is reform in "Nigerian" Islam? ......................................................... 77

3.2 The Shīi ì movement in Nigeria ................................................................ 83

3.3 The Jamāçat Tajdīd al-Islām (JTI) in Nigeria ............................................ 84

3.4 From Maitatsine to Boko Haram ……………………………………... 86

3.5 Salafiyya oriented groups ..................................................................... 89 
$4 \quad$ The Izala movement between success and failure .............................. 91

4.1 Sheikh Ismaila Idris and the Izala question .............................................. 91

4.2 JIBWIS: The formation of the Izala movement in 1978 ................................ 95

4.2.1 One constitution and two factions .................................................. 99

4.2.2 The structure of the organization .................................................... 106

4.2.3 The current leadership of the Izala movement ................................ 111

4.3 The Izala movement and innovation ……………................................... 117

4.3.1 Definition(s) of bid'a ........................................................................ 117

4.3.2 The Izala discourse on bid'a .......................................................... 127

4.4 The Izala movement and Wahhābism ......................................................... 134

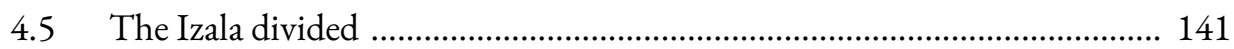

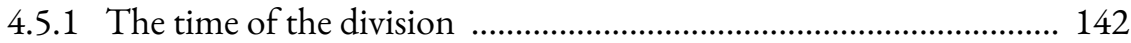

4.5.2 Reasons for the division ................................................................... 146

4.5.3 The Izala "war of words" between Kaduna and Jos ........................ 156

4.5.4 Attempts at reconciliation ................................................................. 164

5 The shari $^{-} a$ debate of 1999 ............................................................... 169

5.1 Who implemented sharía? ................................................................... 171

5.2 Proponents and opponents of the shari ${ }^{-} a$-project .................................... 178

5.2.1 Proponents of shari'a ...................................................................... 179

5.2.2 Opponents of the re-implementation of Islamic law ....................... 181

5.2.3 The Federal Government, the federal states, the 'ulamä' and grassroots' positions on shari'a re-implementation .................................. 185

5.3 Izala's contribution to the re-implementation of Islamic law .................... 190

5.4 The Izala movement, Sufis and sharía law: A chance for reconciliation? 195

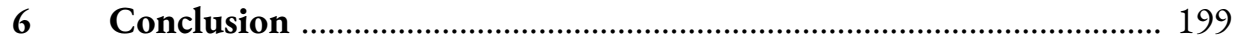

$7 \quad$ Bibliography ……………………………………………………….... 209 


\section{Foreword}

The present text has originally been my doctoral dissertation, which I submitted to my examination committee at the University of Bayreuth in 2011. For publication, this text has been considerably revised and updated. I want to express my gratitude to all people who assisted me in my project at different stages and apologize to all those I did not mention here by name. First, I am very thankful to Professor Ulrich Berner who encouraged me during my undergraduate, graduate and during the process of writing my PhD-Thesis. In the field of Religious Studies, I learned a lot from Professor Berner and I am really lucky and happy for having studied and worked under his supervision. Without the assistance and unlimited patience of my supervisor, Dr. Franz Kogelmann, this dissertation would not have been accomplished. I thank him for his kind support, critical readings and for sharing his knowledge about shari' $a$ and Islam in Africa. Professor Roman Loimeier's lectures at Bayreuth University about Islam in Africa turned my attention to Nigeria and the Izala movement. I am grateful to him for providing me with contacts and networks during my field research. I thank him for the discussions and valuable information he provided me on the Izala movement at different stages of my $\mathrm{PhD}$-project. I also am grateful to him for facilitating the publication of this project. Through Professor Kurt Beck, I learned how to deal with Islam from an anthropological perspective. I enjoyed his seminars, lectures and discussions. I am thankful to him for his kind assistance in all directions. Dr. Philip Ostien assisted me 
in Nigeria in many directions and there are no words to thank him enough for his kind support and assistance. Na Gode! I am equally thankful to Professor Umar Danfulani (Jos) who supported me a lot: He did not only host me in his department, but linked me to many Nigerian scholars of religions. I learned a lot from Professor Azonzeh Ukah and appreciated his comments, corrections and critical readings, and would like to thank him for his kind assistance. I thank Professor Christoph Bochinger and Professor Gabriele Cappai for their support and for discussing my work in their excellent methodology course: Professor Sani Umar, Professor Abdukader Tayob, Professor Rüdiger Seesemann shared their knowledge with me and provided me with ideas and theoretical orientation. I am thankful to all of them for taking the time to discuss my project with them. Many thanks go also to Cathlene Dollar for her corrections, critical reading and recommendations. I thank all my interviewees in Nigeria for giving me time, sharing their ideas, and being patient with the numerous questions, I raised.

In Nigeria, I want to thank, for their kind assistance, Professor M. Yahya, Professor Musa Gaiya, Dr. Gwamna, Dr. Yilpet, Dr. Sani Modibbo, Sheikh Dr. Abdurrahman Lawal Adam, Mallam Kabiru, Barrister Ahmad Garba, Mallam Sani Abdurrazaq, Dr. Dawood Abubakar, Rahina Muhammad, Dr. Chikas Danfulani (all in Jos), Yusuf Abdullahi Yusuf (Jos and Katsina), Professor Afe Adogame (Princeton), Dr. Selome Kopunu (Lagos), Dr. Remi Brito (Lagos), Dr. Umar Adam (Kaduna), Babangida (Katsina), Mallam Salisu Bala (Zaria), Sheikh Abubakar Mujahid (Zaria), Mallam Amino Kano (Kaduna/Kano), Dr. Maren Milligan (USA), Mallam Khidr (Kano), Mallam Uthman (Kano), Saleh Ibrahim (Jos), Professor Dr. Aljunnar (Sokoto), Dr. Kamal Babakr (Sokoto), Dr. Salisu Bala (Kaduna), Mallam Musa (Arewa House, Kaduna), Dr. Gwadebe (Arewa House, Kaduna), Dr. Haruna Wakili (Mambayya House, Kano), Professor Muhammad Munkaila (Maiduguri) and, last but not least, Dr. Balarabe Zulyadaiyni (Maiduguri).

My family in Tunisia and my friends (Aissa, Amr, Kamel, Abdou, Ronny, Oliver, Marcus, Eva, Silke, Tobi, Ahmad, Valerie, Salma and many others) equally helped me a lot during the last years and I am very grateful to all of them. Dr. Meron Zeleke and Dr. Halkano Abdi corrected parts of this dissertation and provided me with critical remarks and corrections. Many thanks to both of them! I want to thank Fadi Saleh and Steffen Herrmann for their efforts in correcting and editing my text. Without their contribution this book would never be published.

The present study and research project was financed by different institutions at different steps of the project. I am grateful to the Tunisian "Ministère de l'Enseignement Supérieur", The Volkswagen Foundation, The International Office (University of Bayreuth), The International Club (University of Bayreuth), and to BIGSAS in Bayreuth for the financial support throughout my doctoral thesis. I am thankful to all members and staff of the Zentralbibliothek at the University of Bayreuth, the "Permanent Site Library" at the University of Jos, the "Mambayaa House Library" in Kano, the "Arewa House Library" in Kaduna, as well as the "Library of the Department of Islamic Studies” at Usman Dan Fodio University, Sokoto. 
Finally I am very grateful to Professor Roman Loimeier for supporting and accepting the publication of my dissertation in Göttingen University Press.

\section{Technical Note}

Non-English words are italicised; the transliteration of Arabic words follows the usage of these terms in the International Journal of Middle East Studies. Non-English words (either Arabic or Hausa) are put in parentheses following their first appearance, e.g. ribā (in Arabic: interest). All dates are cited according to the "Common Era" (C.E.) calendar, numerically equivalent to the Christian A.D. calendar. Please also note that Internet sources as well daily or weekly journals quoted in the footnotes will not be quoted again in the bibliography. 



\section{Introduction}

Nigeria is the most populous nation in Africa. According to UN population estimates, more than 200 Million inhabitants are living in this West African country. ${ }^{1}$ Nigeria is ethnically, linguistically, and religiously highly heterogeneous. More than 500 languages $^{2}$ are spoken in the country. Hausa in the north, Ibo in the southeast and Yoruba in the southwest are considered to be both the most important languages and dominant ethnic groups. Nigeria borders Cameroon and Chad in the east, the Republic of Niger to the north, the Republic of Benin in the west and the Gulf of Guinea to the south. In the media, Nigeria has become known for oil, ethnic and religious crises. In the Niger Delta area, where many international oil companies operate, explosions related to leaking pipelines as well as kidnappings of Nigerians, foreign residents and workers of oil companies happen intermittently. ${ }^{3}$ The situation in this area of Nigeria is a result of unequal distribution of oil income. Nigeria has been a member of the Oil Petroleum Exporting Countries (OPEC) since 1971 and yet it has been considered at

1 https://population.un.org/wpp/Download/Files/1_Indicators\%20(Standard)/EXCEL_FILES/1_ Population/WPP2019_POP_F01_1_TOTAL_POPULATION_BOTH_SEXES.xlsx (23/04/2020). 2 http://www.ethnologue.com/show_country.asp?name=NG (4/10/2010) speaks of 527 "individual languages" in Nigeria among which 512 are "living languages" and 11 have "no known speakers."

${ }^{3}$ During the $1^{\text {st }}$ October independence celebrations in 2010, a car bomb explosion in Abuja killed eight people and injured three. Rebels from the Niger Delta area seemed to be behind this action; see https:// www.aljazeera.com/news/africa/2010/01/201012314018187505.html (2/10/2010) for more details. 
the same time by the World Bank as being among the poorest countries in the world. The World Bank report of 1996 summarizes the situation of the country in the following: "Nigeria presents a paradox. The country is rich, but the people are poor." Indeed, this paradox is confirmed by many Nigerians who see themselves as being excluded from the wealth of their own federation. ${ }^{5}$

Muslims and Christians are the two major religious groups in the country. Adherents of African Traditional Religions (ATR) are a minority. There are no reliable statistics at hand regarding religious affiliation, though. Most Muslims live in the northern part of the country, whereas the majority of Christians live in the south. However, there are no clear-cut religious borders in Nigeria. Adherents of Islam, Christianity and African Traditional Religions can be found everywhere in the country and they frequently coexist side by side. Equally, ethnic conflicts in Nigeria are often misunderstood by outside observers and are interpreted as purely religious conflicts. In fact, it is not easy to separate ethnicity from politics, religion, and economy in Nigeria. All these aspects are tied together in a complex way. Events documented by the media as "religious" conflicts between Muslims and Christians in many cases go deeper than this simplistic and often superficial explanation. The events in Jos in 2001, 2004, 2009 , and $2010^{6}$ were interpreted thus as a religious struggle between Muslims and Christians. ${ }^{7}$

Nigeria gained its independence from Britain in October 1960. Nigeria's First Republic lasted from 1960 to 1966, the Second Republic from 1979 to 1983, the Third Republic started in 1993, when democratic elections were organized and subsequently annulled by the military. Today, Nigeria is a federation of 36 states with Abuja as the Federal Capital Territory (FCT). In 1999, the Fourth Republic was proclaimed after a democratic election. This election was the fourth attempt to create a civilian government in Nigeria after three failed attempts and a long experience with military dictatorship: the Nigerian army effectively ruled Nigeria from 1966 to 1979 and from 1984 to 1999.

Nigeria has also been a member of the British Commonwealth since 1960. In 1986, the then president of Nigeria, Ibrahim B. Babangida, registered his country also with the Organization of Islamic Conference (OIC). This shows that Nigerian politics is oriented more towards economic benefits rather than religious loyalties. The postcolonial era in Nigeria is characterised by political, social and religious instability. Since its independence from Britain in 1960, the country has passed through a tumultuous political experience. The civil war between 1967 and 1970 revealed that the country was far from being stable. This fact was confirmed by almost thirty years of military

\footnotetext{
${ }^{4}$ See World Bank 1996.

5 Informal communications with Nigerians during my field research 2006/2007 and 2008.

${ }^{6}$ For a background on the Jos conflict, see Higazi (2007) as well as Ostien (2009).

${ }^{7}$ For the Kaduna 2000 riots and the Muslim-Christian controversy related to sharí' $a$ see Danfulani (2005).
} 


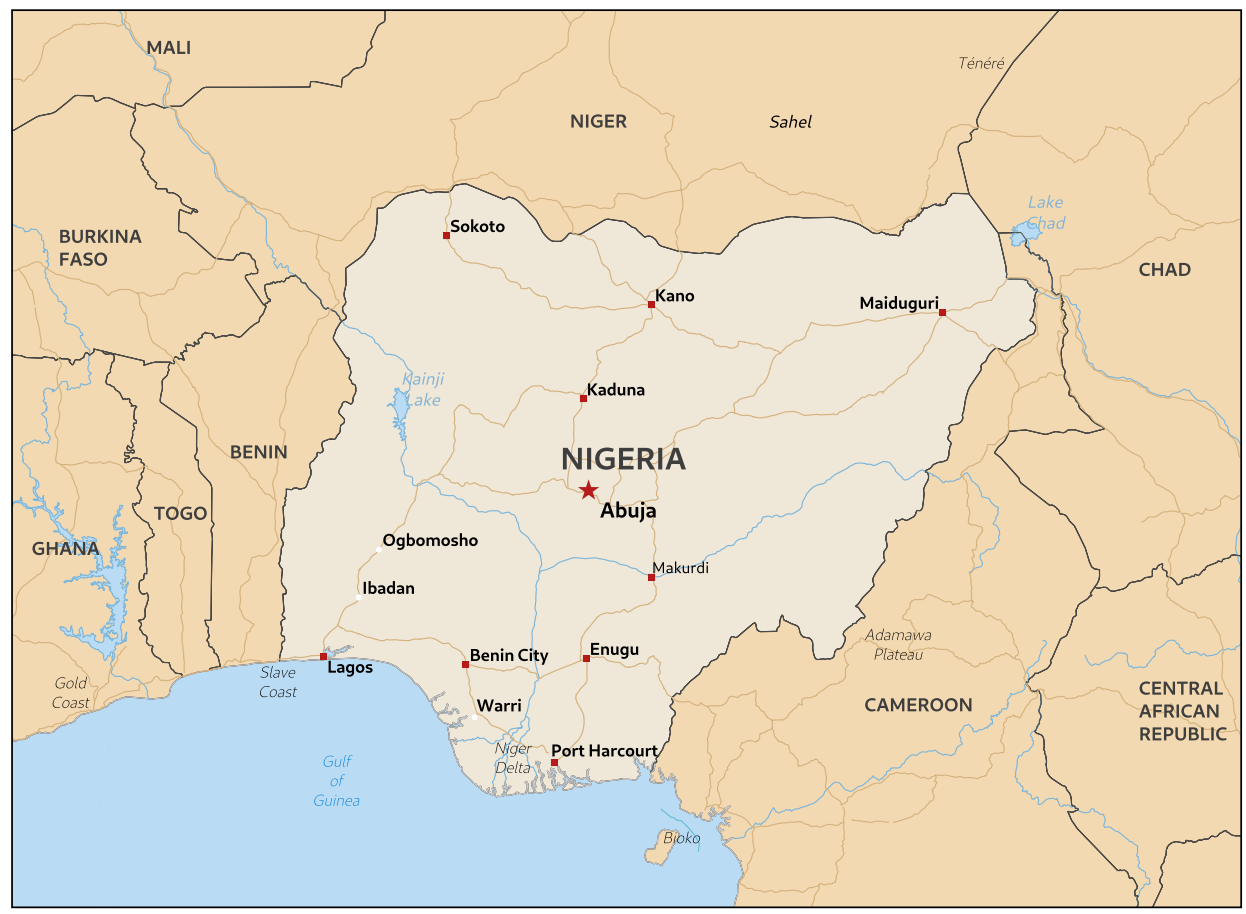

Map 1: Map of Nigeria (made with Natural Earth - naturalearthdata.com).

dictatorship and four attempts at democratic rule in the last sixty years of independent Nigeria.

Nigeria's first constitutional debate of 1979 was the first significant event in the country when religious division became more visible. This had to do with a controversy related to the constituent assembly and the resulting $\operatorname{shari}^{-} a$ debate. The discussions amongst Muslims and Christians to include Sharia Courts of Appeal in the Nigerian constitution led to political turmoil. The same problem was raised again 1999 when Zamfara State's Governor Ahmad Sani Yariman Bakura declared full reimplementation of $\operatorname{shari}^{-} a$ law in his state. After him, eleven other northern states introduced Islamic criminal law. During that time, many observers began to doubt the new democratization process in the country. Debates were not only held in the media and amongst politicians, but also in academia. Scholars and researchers from different countries and disciplines ${ }^{8}$ developed a keen interest in the $\operatorname{shari}^{-} a$ issue. It became clear

8 A few conferences that have dealt with the recent debate, namely, "The Sharīa Debate and the Shaping of Muslim and Christian Identities in northern Nigeria, at the University of Bayreuth, Germany, 11-12 July 2003, and "Comparative Perspectives on Sharī'a in Nigeria" at the University of Jos, Nigeria, 15-17 January 2004, both founded by the VW-Foundation and leading to a publication, namely, Ostien, Nasir and Kogelmann (eds. 2005). Also a multidisciplinary research project titled "Sharīa Debates 
Ramzi Ben Amara: The Izala movement in Nigeria

that this phenomenon had been discussed in a broader African context, especially in multi-religious societies where religion and identity are adjunctive.

\subsection{The scope of research}

In 2005, ${ }^{9}$ I undertook a pilot study in Nigeria where I built a network of contacts in Jos and in a few other states in the north. ${ }^{10}$ At that time, I was developing ideas regarding my PhD project. Shari' $a$-re-implementation was a current topic at that time. Informal discussions with scholars at the University of Jos, with both Muslims and Christians, regarding the possibility of such a project as well as accessibility to Muslim communities in the north, informed my research project to a major extent. Previous studies of the Izala movement in Nigeria highlighted that this movement was one of the most successful reform movements in the West African country. According to my knowledge, since the studies of Umar, Loimeier and Kane in the 1990s, no other academic work had been published on the recent development of the movement in Nigeria. During my stay in Jos, where the Izala movement has its headquarters, some informal contacts helped me to establish networks with members of the movement.

The Izala organization was founded in Jos and many of its leaders live in that city. My connection with the Department of Religious Studies of the University of Jos facilitated contacts with scholars of religion. Informal discussions (with experts of religion, students, and members of different religious groups like Sufis and Izala) allowed me to collect information about the field and the religious situation in general. It was also an occasion to collect names and positions of future interview subjects. It became clear that Jos was the ideal place to conduct research on the Izala movement. I was able to complement this first overview study regarding Jos and the Izala movement with a visit to other towns that are different from Jos and the Middle Belt region of Nigeria. I used the opportunity to conduct research in Lagos and to have informal discussions with Muslim scholars at Lagos State University (LASU) from the Department of Arabic and Islamic Studies. These discussions focussed rather on Islamic law and the reimplementation of $\operatorname{shari}^{-} a$ than on the development of the Izala movement.

and Their Perception by Christians and Muslims in Selected African Countries" was funded between 2006 and 2009 by the same foundation and hosted by different universities in Germany, Kenya, Nigeria, Tanzania and Sudan. This research project was a forum for scholars from different disciplines to deal with the shari $a$ issue in different countries and contexts; see all details under http://www.sharia-inafrica.net.

9 I accomplished my Magisterarbeit (MA-thesis) entitled "Die Entwicklung der Šarīa-Frage in Nigeria Ende der 1990er Jahre" in Religious Studies at the University of Bayreuth. The study deals with the historical development of the Sharî́a question in Nigeria before, during and after the colonial time with a focus on Islamic law and recent debate in northern Nigeria.

${ }_{10}$ Through the VW-Project on shari'a, a strong partnership was built between the Department of Religious Studies (Lehrstuhl für Religionswissenschaft) of the University of Bayreuth, Germany and the Department of Religious Studies of Jos University, Nigeria. 
After this short visit to Nigeria, I drafted a proposal of the study. My plan was to look at the Izala movement's recent developments and to add two major aspects: the division of the movement into two main factions (Jos and Kaduna) and the re-implementation of shari'a law that influenced (or is influenced by) the Izala movement in one way or another. The shari ${ }^{-} a$-factor in relationship to the Izala movement has not been studied before. The contribution of the movement to the so-called shari' a project as well as its perception were not considered in academia. Back in Bayreuth, I joined the Volkswagen Foundation (VW) project "Sharīa Debates and Their Perception by Christians and Muslims in Selected African Countries" (2006-2009). This project was an opportunity to train methodological skills and research tools (see methods below). Debates with colleagues and senior researchers from different disciplines (Religious Studies, Anthropology, Islamic Studies, Political Sciences, Sociology, Theology, etc.) and critical discussions of my research proposal challenged my project at different stages.

I conducted first fieldwork in Nigeria between December 2006 and March 2007. During this time, I lived in Jos while regularly making short trips to Kano, Kaduna, and Zaria. The strategy during this field research was to collect preliminary data and make contact with leaders of the Izala movement as well as prominent Sufi scholars without ignoring those who regard themselves as independent from both. The spectrum of interviewees included both insiders and outsiders of the Izala movement in order to develop a clear and objective view on Izala movement and shari' $a$. The interviews on the Izala movement supplemented with literature research at different institutions in Jos, Kano, and Kaduna. At the University of Jos, I consulted and collected BA- and MA-Dissertations in Arabic, Islamic and Religious Studies. Relevant material from the library of Mambayya House in Kano and Arewa House in Kaduna were copied and documented. These institutions provided me not only with written material and names of important personalities related to the Izala movement and the re-implementation of $s_{a}{ }^{-}{ }^{-} a$, but they were also starting points for extending my network of contacts and potential interview partners.

The objective of this procedure of research was to interview representatives of the two basic factions of the Izala movement: Jos and Kaduna, but also to speak with ex-members of the movement and outsiders. At the same time, I was able to interview representatives of the two dominant Sufi brotherhoods of the Qaadiriyya and the Tijāniyya. The major goal for the first stage of fieldwork was to identify figures of the movement, to create an overview of developments of the organization, to analyse its relationships to Sufis past and present, and, finally, to identify the Izala movement contribution to the shari'a project of 1999. The focus during this initial fieldwork was the 'ulama', the experts and the religious leaders with the aim of extending these interviews to grassroots level during future field research. The 'ulamă' as well as many religious scholars are the ones who witnessed the establishment of the Izala movement towards the end of the 1970s. They played a major role in the history of the movement. When it comes to doctrinal differences between the Izala movement and groups 
outside of the movement, the leaders of the movement were the primary source of ideas and religious doctrines.

In 2008, I enlarged the spectrum of the study to include other parts of northern Nigeria and added more case studies derived from different contexts. I conducted my field research between February and April 2008. During this period of the research, I visited eleven out of twelve northern states. The only exception was Niger State. This procedure was again a result of my contacts in the field and the availability of interview partners and by no means an exclusion of specific actors. I was also able to interview the leaders of the Izala movement in Jos and Kaduna in different areas and I also covered towns like Maiduguri, Sokoto, Zamfara, Gombe and Katsina. ${ }^{11}$

Thematically, I explored three basic topics: the establishment of the Izala movement as an organization, its presence in different regions of the north and its division into two major groups as well as the attempts of reconciliation constitute the first part of the interviews. Issues of leadership, money, and structure were also part of these discussions. The second topic is the relationship between the Izala movement and Sufi brotherhoods past and present. In order to analyse this relationship between the 1970s and the beginning of the 1990s, I used the studies published by Loimeier (1997a), Sani Umar (1983 and 1988) and Kane (2003). Through interviews with Sufi and Izala movement representatives and ordinary members, I analyzed this relationship from the perspective of today's leaders of the movement. Important here is the discourse of both groups - Sufis and Izala - as well the change in their relationship. The third and last topic of the interviews was the re-implementation of $\operatorname{shari}^{-} a$ law in northern Nigeria and its impact on the Izala movement and the Sufis.

On several occasions, Izala movement leaders claimed that the movement was the initiator of $\operatorname{shari}^{-} a$ in the north. Expectations regarding the shari' $a$ project were high. The re-implementation of $\operatorname{shari}^{-} a$ started at the political top (by a single governor, namely the Zamfara state governor) and was accomplished by the masses: shari'a reimplementation in other states was enforced at the grassroots level. The re-implementation of $\operatorname{shari}^{-} a$ itself was regarded by northern Muslims as a "success." All Muslim groups in northern Nigeria, with the exception of the "Shī'ites" (a movement known among Nigerian Muslims as "Yan Shia", although the movement calls itself "Islamic Movement in Nigeria") under the leadership of Ibraheem Zakzaky, ${ }^{12}$ accepted shari' $a$ and supported for its re-implementation. Through this pressure to implement Islamic law, a new situation developed: a situation in which all Muslim groups needed unity. According to Ousmane Kane, "any outbreak of major conflict between Christians and Muslims caused Muslim factions to unite and forget, at least temporarily, their doctrinal divisions to fight the common enemy" (Kane 2003: 211). The shari' $a$ issue was a

\footnotetext{
${ }^{11}$ I am thankful to Dr. Philip Ostien for assisting with travelling in northern Nigeria. He was conducting research on Sharîa Courts in the twelwe Sharía States. Joining him in 2008 allowed me to move in many places and conduct interviews with several Izala movement members and non-Izala movement people in different states of the north.

${ }^{12}$ For his biography and the question of Shī ism see Suleiman (2005).
} 
major contention between Muslims and Christians. The Izala movement as well as the Sufis had no option but to come together.

There are some claims within the Izala movement that the movement was the initiator of shari'a and that Ahmad Sani Yariman Bakura, the governor of Zamfara state, was a member of the Izala movement. There is no definitive answer as to how he became a member and how he was influenced by the Izala movement. Sufis also claim that they were behind the re-implementation of $\operatorname{shari}^{-} a$ in northern Nigeria. If we take the re-implementation itself, then it can be considered as the realization of a "dream" of many Muslims to re-establish what has been removed during colonial times. The implementation of $\operatorname{shari}^{-} a$ was a matter of identity related to the situation in the legal field that existed during the time of the Sokoto caliphate and that was related to the fact that the British colonial administration prohibited $\operatorname{shari}^{-} a$. Northern Nigerians are emotionally still highly attached to the Sokoto Caliphate and its history. For them, the Izala movement and $\operatorname{shari}^{-}$a go side by side. The Izala movement's doctrine feeds into the $\operatorname{shari}^{-} a$ project and $\operatorname{shari}^{-} a$ can be regarded as a realization of the Izala movement doctrine, namely, the Islamization of the society (not to be confused with an Islamic State project) - as some scholars describe it. ${ }^{13}$

During the field research, I was able to interview ordinary members and ex-members of the Izala movement in order to gain a grassroot perspective on the movement. Although many members (especially young people) could not tell much about the history of the Izala movement from their own biography, they provided insights about the Izala movement from a different perspective. The environment in which they grew up was an additional source of information on the Izala movement. These interviews were supplemented by visits to Izala movement institutions in Jos and other towns, mainly mosques and schools of the Izala movement. In Gombe, I had a unique opportunity to visit an Izala hospital.

After providing a critical review of the literature on the Izala movement in Nigeria and its development in and outside the country, I will clarify the methodology used throughout the text and will introduce the theoretical framework. The second chapter serves as a historical background for the next chapters. I will first present the history of Christianity and Islam in Nigeria with an emphasis on the Sokoto Caliphate. I will then also provide an outline of other Islamic groups in the country. The Sufi brotherhoods, for instance, played an especially important role in the spreading of Islam in the country. In the colonial period, the British introduced "indirect rule" in Nigeria. This mode of government as well as the development of Islam during the British colonial and post-colonial periods will be analysed accordingly. Equally, I will discuss the strug-

\footnotetext{
${ }^{13}$ Informal discussion with Professor Musa Gaiya from the University of Jos (18 December 2006). This scholar of religion sees the Izala movement project in no way as an attempt to Islamize the state. According to him, the efforts of the Izala movement have to be seen rather as an effort at "Islamization" of the society by insisting on several societal aspects such as Islamic education, dressing code, education of women, ban of alcohol, etc.
} 
gle between Sufis and reform-oriented Islamic groups in the 1970s, focussing on the struggle between Sheikh Gumi and the Sufi brotherhoods.

The Izala movement has started a reform project in Nigeria, but it is not the only Islamic group with such a plan. In chapter three, I will discuss the notion of "reform" in the Nigerian context. The examples of the Shī'i movement, the Jamāat Tajdīd alIslām (JTI), Maitatsine, Boko Haram and different Salafiyya groups are manifestations of the same phenomenon. Some of these groups were established at the same time at which the Izala movement was founded, others, such as Boko Haram, are contemporary movements.

Chapter four deals with the establishment of the Izala movement. It gives an overview of the life and contribution of Sheikh Idris, the founder of the movement. It serves to clarify issues related to the Izala movement, like the discussion on innovation (Arabic: bid'a) and the relationship between the Izala movement and Wahhābism. In this chapter, the development of the Izala movement from the beginning of the $1990 \mathrm{~s}$ is outlined. In particular, the division of the movement into two major groups is analysed. The division of the Izala movement, which was mostly unclear to non-Muslims in northern Nigeria, was a big event within the movement. The doctrinal differences and attempts of reconciliation as well as the amendment of the Izala movement constitution are important parts of the movement's history. Doctrinal controversies and internal debates are in many cases hidden from outsiders. This chapter is an attempt to clarify some aspects of internal differences within the Izala movement. I will ananlyze the discourse(s) within the movement and the rationale of leaders regarding the division on the basis of interviews and writings from within the Izala movement.

One cannot deal with the Izala movement without discussing its relationship with the Sufis. In chapter five, this relationship is elucidated. In the context of the re-implementation of Islamic law, the Izala movement-Sufi struggle took another turn, in fact. The controversy surrounding the re-implementation of shari' $a$ in northern Nigeria was huge, yet shari'a implementation was perceived differently by different parties. Some speak of a project of Islamization of Nigeria and see in shari' $a$ a danger to the democratization process for the federation during the Fourth Republic. For many Muslims, shari ${ }^{-} a$ was already integrated in the constitution, however. Freedom of religion was thus guaranteed in Nigeria's constitution and what happened was an adaptation of an Islamic law that already existed in northern Nigeria for hundreds of years. In this fifth chapter, the discussion moves beyond the Muslim community of Nigeria, because the shari ${ }^{-} a$ controversy in the country was a national dilemma. This chapter also discusses intra-Muslim discourses on $\operatorname{shari~}^{-} a$, especially the Izala-Sufi debate(s). In addition, the discourse between Muslims and Christians is illustrated. The concluding chapter serves as a summary of the results and findings carried out in this study.

The objective of this dissertation is to go beyond the studies of Loimeier, Sani Umar and Kane, and to some extent also the contributions of Andrea Brigaglia (see the bibliography). Apart from dealing with the current Izala movement in Nigeria and its leadership and structure and updating the work of previous scholars, a central ob- 
jective will be to examine the Izala-Sufi relationship today within the shari'a project. Sharía re-implementation in Nigeria brought all Muslim groups together, irrespective of their doctrinal differences. Apart from the Shî ${ }^{-}$ites under their leader Ibraheem Zakzaky, all Muslim groups and individuals welcomed the re-implementation of the shari ${ }^{-} a$. How different Islamic groups dealt with their differences within the context of the shari ${ }^{-} a$ debate will be a central question in this study. The study particularly attempts to answer the following questions: How did Islamic groups (Izala movement or Sufis) legitimize their initiation of the shari ${ }^{-} a$ project with the umma (Muslim community) in northern Nigeria? What kind of discussion related to shari ${ }^{-c} a$ took place? What was the role of other Muslim groups within this project?

\subsection{The state of the art}

In academia, the works of Sani Umar, Loimeier and Kane are the best known regarding the Izala movement in Nigeria. ${ }^{14}$ In addition, there are also studies dealing with the situation in the Republic of Niger (such as Masquelier's (2009) study on Muslim women in Dogondoutchi town; Grégoire's (1993) on Maradi town; and Alidou's (2005) on Muslim Women). Literature on the Izala movement in other contexts like Ghana, Chad, and Cameroon is limited, in contrast. These other contexts could be a subject of investigation in the future. The material collected in Nigeria at different universities shows that much research on the Izala movement can be seen as case studies that deal with local developments of the movement in a particular place or town. Some of these studies discuss only one aspect related to the Izala movement such as education or mosques. The founder of the Izala movement and the current leaders of the movement were also often the subject of studies. The studies listed below are in no way complete, however, they are only samples of academic research related to the Izala movement done by Nigerian and other scholars.

The Izala movement attracted the attention of quite some scholars from both Western and Islamic countries. Sani Umar, a Nigerian Muslim from the north, did intensive work on the Izala movement and looked at the relationship between Sufism and anti-Sufism. As a native speaker of Hausa from Jos, he had access to the movement and conducted his field research during a very important period of the organization's development. He submitted his BA dissertation at Jos University in 1983 and his MA at Kano University. Muhammad Sani Umar is considered to be the first scholar who dealt with the Izala movement academically (see Umar 1983 and 1988). Umar traces the changes of Islamic identity from Sufism to anti-Sufism in the postcolonial period (see Umar 1993: 154-178). He takes note of a "popularization” of Sufism in Nigeria during the 1940s and relates the growth of anti-Sufism in the 1950s to anti-colonial tendencies in Kano, Sokoto and Katsina. The revival of Islam started according to

${ }_{14}$ Alexander Thurston's recent publications (2016 and 2018) could not be considered any more for the present text (see bibliography, though, for the respective titles). 
Umar with Sa'ad Zungur (1915-1958) and Abubakar Gumi (1922-1992). This trend continued during the 1970s with the popularization of Sheikh Gumi's views by the media. Through the establishment of the Izala movement in 1978 as an organized entity, the struggle between the movement and Sufi brotherhoods became more visible. The author concludes that anti-Sufism is a form of "protest" and "reorientation" within the Islamic religious field in Nigeria.

The studies of Loimeier and Kane are two different analyses of Islamic reform in Nigeria. The former is a Western scholar of Islam, the latter a Senegalese political scientist coming from a Sufi background. Both researchers conducted fieldwork at the end of the 1980s and took the city of Kano as a starting point for their studies. Loimeier looks at the development of the Sufi brotherhoods in Nigeria (the Qaddiriyya and Tijāniyya) and their struggle for power and for followers. The doctrinal differences between both Sufi brotherhoods especially during the 1950s and 1960s are well documented. The advent of Sheikh Gumi as a pioneer of reform in Nigeria led to a shift of the religious landscape in the north due to the fact that Gumi's attacks led to the unification of the Sufi brotherhoods. The dispute between both Gumi and the Sufi brotherhoods exceeded an intellectual dispute. In the early 1970s, Gumi and several Sufi leaders exchanged attacks via their writings. Loimeier's work can be considered as a fundamental background-study of the Nigerian religious and political landscape after independence. Sheikh Gumi played a central role during this period. Loimeier also analyzed Gumi and his reform program in other publications ${ }^{15}$ as well as in a general overview of Islamic reform in Nigeria in comparison to other African contexts (see Loimeier 2005: 29-48).

It was no surprise that an organization that shared Sheikh Gumi's stance vis-à-vis the Sufi-brotherhoods was established. This idea of establishing an organization was realized by Ismaila Idris through the establishment of the Izala movement. According to Kane, the Izala movement calls people to Islam as based on its peculiar understanding of the Qur'àn and the sunna. The Izala movement thus invited followers to the old tradition of the al-salaf al-sălih (pious predecessors; the first generations after the death of the Prophet), but at the same time, the Izala movement established modern schools. The movement recruited 'ulamä' as well as young people at an early stage of its establishment. It then developed into an officially registered organization in Nigeria. The Izala movement adapted itself to the needs of people and concentrated on several aspects of social life to propagate its doctrine. Islamic education played an important role in the Izala movement. Through Kane's study, it is possible to identify several main figures of the movement and its development in Kano state. Although Kane's book was published in 2003, it was based on the materials he collected for his $\mathrm{PhD}$ dissertation at Bordeaux University (1993). This valuable study on the Izala movement started with the rise of the movement and ended with its "domestication" - to use Kane's concept. In other publications (see Kane 1994: 490-512) Kane analyzes the main figures and the social environment in which the Izala movement developed and

15 See Loimeier (1997b, 1997c and 2003). 
relates it to economic and political changes in and outside of Nigeria (Sheikh Gumi's influence, the Saudi factor, etc). Kane (1999: 324-340) sees in the Izala movement as a project of "modernization" of Islam and links it with several other reform movements in West Africa; for instance, in Mali or Senegal. Studying abroad and establishing Islamic schools mainly sponsored by Islamic countries such as Libya or Saudi Arabia led to questioning the old tradition of Sufism and the legitimacy of its doctrine.

These three studies on the Izala movement are considered to date to be a basic source of information on the movement and its development. The three mentioned scholars conducted field research on Izala movement during the 1980s. Sheikh Gumi played a central role in the three works. Apart from the PhD-dissertation of Andrea Brigaglia (2004), which focusses more on the 'ulam $\vec{a}$ ' of northern Nigeria and deals with Izala movement only partially, there has been no work on the movement during the past few years. In PhD-dissertations written by Nigerian scholars, the Izala movement is presented as one among many other Muslim groups or in the context of Sufi and anti-Sufi opposition.

Sheikh Abubakar Gumi with the help of Ismail Tsiga (Gumi and Tsiga 1992) published his own autobiography in 1992. Surprisingly, the prominent Islamic scholar did not say much about the Izala movement. Apart from mentioning his agreement with the movement and its ideas, as well as supporting its ideology, Sheikh Gumi stated that he never belonged to the Izala movement in a formal way. He indicates how his student and Izala movement founder, Sheikh Ismaila Idris, used his book to criticise Sufism. When discussing the movement, he qualifies members of the Izala movement as enthusiastic young people who joined the movement and contributed to its spread. The book deals more with important events in the life of Sheikh Gumi, such as his education, teaching, politics, and visits abroad. The preaching and his confrontation with Sufi leaders are also mentioned in this book.

The book by Tanimu Aliyu (Ignantaccen Taribin Jama'atu Izala til Bid'ah wa'Ikamatis Sunnah, n.d.) written in the Hausa language about the Izala movement is considered by many Izala movement members in Jos to be a main source of information when it comes to the history of the movement and the biography of Sheikh Idris. It also documents the major events of the movement throughout its history. Not only does it document the important events and meetings, but it also lists the main figures who joined or assisted Sheikh Idris. In addition to that, Tanimu Aliyu reflects on the formation of some Izala movement institutions. Part of the publication is concerned with problems within the Izala movement, as well as opposition to the leader; yet, it still illustrates the success of the group while following the path of the Sheikh.

The PhD-thesis of Abdulfattah O. A. Olayiwola (1997) ${ }^{16}$ is a study on Islam and Muslims in Nigeria. Apart from dealing with the history of Islam in the West African country, the study focuses on the rivalries between Sufis and anti-Sufis (i.e. the Izala movement). The author places both tendencies at the same period. Olayiwola sums

16 Olayiwola also gives a good analysis of the doctrinal difference between the two groups (1997: 109-160). 
up the Izala movement's criticism of Sufism in three main points: Sufism in general, the Qādiriyya Sufi brotherhood, and the Tijāniyya Sufi brotherhood. The movement underwent a period of formation and propagation of its ideas which led to the consolidation by its founder, Sheikh Ismaila Idris. This period can be considered as a time of success for the movement. Finally, Olayiwola concludes that the Izala movement reached a stage of "disintegration". He adds that internal problems such as the division of the Izala movement, the style of leadership, and the approach to Islamic da'wa all contributed to the movement's disintegration.

In Nigerian universities, especially in the departments of Islamic and Arabic Studies, there are several dissertations dealing with Islam, Muslims, and Islamic organizations. In a number of $\mathrm{BA}$ and $\mathrm{MA}$ dissertations, it is not difficult to ascertain the affiliation and to see whether the author is sympathizing with either the Izala movement or a Sufi brotherhood. These B.A. and M.A. projects are valuable to provide the reader with insight into the movement at the local level. They are also a source of information about names and key figures of the Izala movement.

The MA dissertation of Isyaku Yandaki (1990) is a valuable document regarding the development of the Izala movement from a historical point of view. After dealing with movements of revivalism in Hausaland that led to the establishment of the Izala movement, the historian gives his point of view on the development of the movement. He identifies three basic periods in the history of the Izala movement: formative (1978-1982), consolidation (1983-1988) and the Izala movement as a social and political reality (1988-1990). Yandaki operates with the notion of "tajdìd" (revivalism) and considers the rise of the Izala movement within this framework. In his analysis, he discusses the Izala movement in relationship to Salafism and Wahhābism before he looks at the movement's relationship to the state, especially to the Muslim community in northern Nigeria. This study is based on elaborate field research and interviews with Izala movement leaders.

Abdurrahman Lawal Adam was an Izala movement member before he left the movement in the mid-1980s. Today he acts as a murshid (advisor) in Jos, in the JNI (Jamāât Naṣr al-Islām, Arabic: "Society for the Victory of Islam", an organization established in 1962 and largely considered an umbrella organization of all Muslim organizations in Nigeria). His M.A. dissertation (1992) was written in Arabic in the Department of Arabic and Islamic Studies at Jos University. It gives insight into Islamic organizations in the city of Jos like the JNI, Sufi groups and the Izala movement. The study clarifies understandings of concepts such as shirk (Arabic: polytheism) and bid'a among others, within these groups. The study is comparative, and explains concepts and doctrines of Sufis and Izala movement from different perspectives before it ends with suggestions for solving these problems in the concluding chapter.

The MA dissertation (2000) of Muhammad Nuhu Gurama delves deeply into the Izala movement division and the reasons for the split in the movement, as well the attempts at reconciliation and the failure to bring the two major Izala movement groups together. This work goes beyond analysing the Izala movement-Sufi relationship and 
discusses leadership struggles in an Islamic organization. The author appears to be a sympathiser of Sheikh Idris as well as the Kaduna faction of the Izala movement, although he tries to present issues from different angles. He highlights the split between "Ismailism" and "Maiganduism" (concepts named after Sheikh Idris and Alhaji Mai Gandu). The author always relies on history to make comparisons between what happened within the Izala movement, on the one hand, and during the time of the Prophet, on the other. He goes even further when he suggests an "ideal" structure for the organization: the 'ulam $\vec{a}$ will be at the top, and all other departments will be under the Council of 'ulama $\vec{a}$. His solutions for bringing the Izala movement factions together are summarized in three major points: mutual toleration, avoiding fanaticism, and learning lessons from the history of Islam.

Ismaila Idris was the founder of the Izala movement. His biography is interesting not only for Izala movement members, but also for outsiders of the movement as well as scholars. The BA-dissertation of Muhammed Sadis Muhammed (2001) highlights his biography. His dissertation is not only a documentation of Sheikh Idris' life in different places (Bauchi, Kano, Jos, etc.), but also a good source of information on the fatāwa (in Arabic: legal opinions) issued by the Izala movement founder on different topics such as jinn (in Arabic: spirit), abl al-kitāb (in Arabic: people of the book; Christians and Jews), polytheism, etc. Sheikh Idris is the main source of legal opinion for the Izala movement faction in Jos. Muhammed Sadis Muhammed's study also clarifies the stance of the Sheikh on a number of theological issues, such as his opposition to freeing individuals from jinn possession and his attack on the celebration of the Prophet's birthday as an innovation. The Sheikh thus opposed eating animals slaughtered by Sufis and Christians and did provide an argument for this through a number of fatāwa (legal opinions).

Jamila Adam Abdallah focuses on the Izala movement contribution to Islamic and Arabic studies in Jos. Part of her work in Arabic (2005) is about the rise of the Izala movement and its founder, but she also focuses on different types of schools belonging to the Izala movement. Her study is a comparative study on the contributions of schools to Islam and Arabic in Jos. She gives a short history of each school, its number of students, and their curriculum and contributions. In addition to that, few actual Izala movement Jos leaders were interviewed, which is common among many studies that shed light on the movement.

Muhammed Safiyyu Abdulkadir's M.A. dissertation (2006) on Bauchi state is a case study of another Nigerian federal state that highlights a specific topic related to Izala movement. The author gives an overview of the establishment of the Izala movement in Bauchi indicating that the movement was initiated in 1979 by people who attended the general meeting in Jos in 1978. The initiative started by establishing a mosque belonging to the Izala movement and performing the juma (Friday) prayer in it. The first Imām in this mosque was Umar Getato. Many Muslims interpreted the establishment of an Izala Friday mosque as a provocation and a danger to the unity of the umma. Although the Imām was arrested several times, the court allowed him to 
perform juma prayer in the mosque starting in 1980. As in many other states, the Izala movement in Bauchi was affected the split of the movement in 1987. The reasons für this division are summarized by the author in eight points, including money, leadership, issues related to figh (in Arabic: jurisprudence) such as marriage, definition of ahl al-kitäb or attachment to the Mālikī School of law. Izala movement preaching in Bauchi is the main subject of this study. Preaching is central and kbutba (the Arabic term for "Friday sermon") are under the supervision of the Council of 'ulamä' of the movement. The first part is an introduction related to a definition of the concept of $k h u t b a$ and focusing on its meaning in a religious context. According to the author, preaching by Izala members in Bauchi goes beyond a religious context and extends to social and political aspects of the community. These three aspects sum up the content of Izala movement preaching. In addition to that, Abdulkadir adds what he calls "khutba tashji iyya" (supportive preaching) through which the Izala movement invites its followers to continue following the path of the movement. This kind of preaching is directed at other people in order to inform them of the organization's ideas. The preaching activities of the Izala movement are set within the framework of the Mālikī School of Law as understood by the founder, Sheikh Idris. Abdulkadir stresses the weaknesses of Izala movement preaching in Bauchi criticising the competence of Imams in terms of language and experience. He comes to the conclusion that this situation will not change since the organization restricts itself to the teachings of Sheikh Idris.

The work of Idris Abdullahi Alhassan (2003) discusses one of the important institutions of the Izala movement faction in Jos. Namely, the Higher Islamic School, Sarkin Mangu, where the headquarters of the organization are situated. Like many projects, the study starts by giving an overview of the city of Jos and Islamic education in the city before the author presents the history of the Izala movement and its main figures, both past and present. This institution was founded in 1985 in Sarkin Mangu, Jos. In 1985, it obtained approval from the Ministry of Education in Plateau State as well from Ahmadu Bello University, Zaria in 1989. The curriculum of the School was divided into two phases: preparatory (three years) and secondary (three years) in order to achieve a Secondary Level Certificate. In addition to highlighting the structure of the school and its institutional framework, the author concentrates on the contribution of three important figures in the improvement of education in this institution. Five major subjects are taught in this school, namely Islamic Education (Qur'ān, tafsir, hadith, etc.); education (methodology, psychology); as well as Arabic, English, and Hausa. In addition, there are three other subjects; the History of Islam, General Knowledge, and Household Training. The author accentuates the objectives of the schools: mastering the Arabic language and Islamic education, and preparing students for university. The author quotes a number of statistics and tables in his study that illustrate the contributions of former school students in spreading Islamic education. The author sees a number of issues as obstacles, such as the lack of books, finances, and low levels of Arabic and English competency. 
Bawa D. Muhammad Anka (2002) presents a case study from Zamfara State where the Izala movement was established on 25 May 1978. Similar to other contexts, the Izala movement attracted young people more than any other population. This resulted in social conflicts within families and between the Izala movement and other Islamic groups. The Izala in Zamfara State are generally more peaceful than those in other states of the north. Also, the division of the movement into two groups happened in Zamfara State and, as a result, two main factions emerged. This division, Izala's changing of methodology, political participation, and shari'a re-implementation are seen by Muhammad Anka as reasons for rapprochement between the Izala movement and Sufi brotherhoods in Zamfara State. In addition, the author highlights the impact of the Izala movement on education (Islamic knowledge, establishing schools, etc.) and on social life (the changing of existing practices) in Zamfara State. This piece of research is different from other studies on the Izala movement since it quotes examples of cooperation between the movement and Sufi-Brotherhoods. The author sees the re-implementation of Islamic law behind this rapprochement.

The studies mentioned above are samples of works written on the Izala movement. The spectrum is wider, though, and depends on the context and department in which the project was fulfilled. Personal observations of BA and MA projects in the department of Islamic Studies, at Usman Dan Fodio University, Sokoto, show that most projects were closely related to Sufism and to the histoy of the Sokoto Caliphate. Only a few projects deal with the Izala movement. This fact can be explained by the fact that Sokoto has been a centre of Sufism since the $19^{\text {th }}$ century. The development of the Izala movement seems to be similar in many northern states of Nigeria. The relationship to Sufis and also the division of the organization into two major groups can be compared in different contexts. The headquarters in Jos and later in Kaduna played a role in guiding the doctrinal lines of the movement.

The Izala movement is a transnational movement. It spread not only to most $\mathrm{Ni}$ gerian states, but also from Nigeria to neighbouring countries like Chad, Cameroon, and the Republic of Niger. The case study of Masquelier (Masquelier 1996: 222-244) on the town of Dogondoutchi, in the Republic of Niger, is a documentation of the development of the Izala movement outside of Nigeria. From an anthropological perspective, she documents the social conflicts that emerged after the establishment of the Izala movement. The new "mode of life" introduced by the Izala movement created social conflicts in the town. The Izala movement emerged during a time of economic weakness and it especially attracted young people. According to the author, it offers a discourse of "morality" in a time of dissatisfaction. The Izala are categorized by Masquelier as reformist and conservative in comparison to mainstream Islam or to traditional Muslim clerics. The Izala's advent created several problems in families and between Muslim groups. The respective discourses analyzed by the author reflected the type of on-going discussions and debates among reform-oriented Muslims (Izala) and țariqa (Sufis) on the meaning of Islam. Their antagonism is manifested in attacks on one group by the other and by the destruction of each group's social image. For 
instance, name-calling often occurs between the groups, using terms such as "donkey, dogs," which illustrates "the animalized other" - as shown by the author.

In another publication (Masquelier 1999:219-250), the struggle for mosque space was a starting point in the history of the Izala movement in the Republic of Niger. After that point in time, the movement changed its strategy to insist on the issue of "knowledge" and the necessity of education, especially the education of women. The movement questioned the existing religious authorities (malamai; Hausa: established Islamic scholars) in order to establish its own system of values and norms, such as the way of dressing, the type of education, amongst others. Masquelier conducted a more in-depth study on the same town in her book Women and Islamic revival (2009). This publication focuses on one charismatic scholar of the town who represents a Sufi answer to reform Islam, and particularly to the Izala movement. This well-respected Islamic scholar, Malam Awal, came to Dogondoutchi with a program to "purify" the town from the Izala movement and establish his own vision of "being a Muslim". In his programme of reform, women play an essential role to the extent that they gain social prestige. If the Izala movement put restrictions on marriage (i.e. quick marriage, reduction of costs, etc.), the new order gives women space for "self-determination" (bride wealth, material needs, fashion etc.). Masquelier highlights that "women's strategic efforts to defend their interests and agendas (...) centered on the redefinition of Islamic orthodoxy" (2009: 277).

The study of Emmanuel Grégoire (1993: 196-115) examines the relationship between trade and Islam in the town of Maradi in the Republic of Niger. To be merchant and using the title Alhaji (pilgrim) is a prestigious social position in that town. This prestige developed recently by joining the Izala movement as a kind of identity marker. Being an Izala in this context is a kind of rebellion against the existing Sufi authorities of Qādiriyya and Tijāniyya as well as against social rules. Maradi's merchants wanted to establish new societal regulations. Instead of establishing mosques they built schools. The new religious affiliation dictated new forms of social behaviour towards others and towards the old, established tradition. Grégoire makes an interesting remark when he compares the Izala ideology regarding the Sufi brotherhoods with the relationship between Protestantism and Catholicism in a Christian context (1993: 114).

Abdoulaye Sounaye's (2009) study deals with the Izala movement in the Republic of Niger, particularly in an urban centre (Niamey). The movement reached the country during the mid-1980s and developed into a socio-religious authority. The Izala movement often uses different strategies to propagate its doctrine. Through the wa'zin kasa (in Hausa: national preaching), the markaz (in Hausa and Arabic: centre of social interaction), and the mosque, the movement's discourse changed from being "marginal and périphérique" to a "plutôt accepté" discourse - as Sounaye points out. The wazin kasa is an occasion for international preaching, wherein preachers from outside the Republic of Niger come to preach. During these few days topics related to the situation of the umma are discussed. This event is also an occasion to collect money for the movement and mobilize people of different ages to join and assist the Izala 
movement. This practice can be compared to the maulid celebration of Sufis but with different objectives and organization. The markaz is the place of "sociability" and appears as a place of continuous education. With a library and a weekly sermon every Thursday, this place attracts merchants, young people and other categories of people. The markaz is a place for building social networks and it can be compared as such with the zawwiya in the Sufi context. The third place is in the mosque. It is a place of building the "communauté Izala" and for "mediation" among its members. Sounaye sees the mosque as a place for building the sense of "collectivity" in the Izala movement. The author indicates three institutions that are used by the Izala movement as "tools" to propagate its doctrine. This strategy aims to bring religious, economic, and social aspects together. It allows the Izala movement to dominate the "religious field" in which it operates. Finally, the author raises an important question related to the institutionalization and normalization of the Izala movement. To what extent is it possible to talk about the dynamism of its reform project in the future?

Robert B. Charlick, a political scientist, thinks that the Izala movement (as the defender of Islamic morals) is an "Islamist movement" that confronted the Nigerian state several times on different occasions since the 1990s (see Charlick 2004: 97-107). The author explains that the movement has been looking for an "autonomous identity" which opposes the existing traditional Hausa social rules. He adds that the Izala movement attracted youth, merchants, and "urban unemployed", and it offers a particular system of values. Charlick concludes that the Izala movement is "used in part to permit a form of capitalist economic modernization (...) without an acceptance of the western beliefs...”

Olivier Meunier, an anthropologist and sociologist who has published extensively on Islam in the Republic of Niger, describes a process of unification of Sufi brotherhoods against Izala movement in the town Maradi that seems to be similar to what Loimeier described in northern Nigeria (see Meunier 1998a). Meunier documents that the founder of the Izala movement in the Republic of Niger, Malam Chaibou, studied in Katsina (Nigeria) and was a student of Sheikh Abubakar Gumi in Kaduna, Nigeria before he returned to Maradi and founded the movement in early 1980s. His preaching was recorded and transmitted by radio. Meunier sees in the Izala movement a "Wahhābī" movement that crossed the Nigerian border to the town of Maradi. He relates the development of the Izala movement to external influences, especially Saudi Arabia. The rise of the movement took place during a time of economic crisis (1980). The Izala movement attracted many unsatisfied people and established itself as a movement against Sufism and the syncretistic practices of Marabouts. In his book on Islam in Niger, Meunier differentiates between three major groups in Maradi: traditionalists (Sufis), rationalists (those who call themselves Mālikīs without any affiliation to Sufism or to reform Islam), and reformists (Izala movement) (see Meunier 1998b). 


\subsection{Methodology}

The study of religion offers different approaches for dealing with the phenomenon of religion. The historical-philological and the empirical-sociological methods are well-established, scholarly methods that are often applied. Many other academic approaches are also accepted, i.e. the anthropological, philosophical, psychological and even feminist approaches. ${ }^{17}$ In this study, I am not defining the concept of "religion" either in substantial or in a functional way as is the case in many publications in religious studies. I am going in fact beyond the problem of definition of the concept of "religion" and the debate behind it, yet, I am aware of the importance of this debate for my project. Also, I will discuss notions of the "religious" through my discussion of the development of the theological debate between the Izala and the Sufis.

The history of the Izala movement in Nigeria and its relationship to Sufis are thus in the centre of analysis of the present study. Due to the lack of literature concerning recent developments, current leaders, and especially on-going discourses within the movement, my intention was to fill this gap in academia and to consider how the central figures of the Izala movement reconstruct the history of the movement. Izala's history from the perspective of its current members, ex-members and non-Izala Muslims seems to be consistent with what has been already written on the history of the movement. The empirical approach discusses actors from different religious backgrounds and affiliations (within Islam) and analyzes the actual discourse(s) and the doctrinal orientation of the movement.

My field research in Nigeria took place between December 2006 and March 2007 and again from February to April 2008. The aim of the first experience in the field was to build networks and connections to the Izala movement in Nigeria and to explore the "religious field" of the city of Jos. This endeavour was facilitated by the department of Religious Studies at the University of Jos. ${ }^{18}$ The first period of research was restricted to identifying central religious figures and leaders in Jos and to exploring the relationship between the movement and Sufism. It did not take much time to identify Izala leaders linked to the founder, Sheikh Ismaila Idris or others who are within the Jos faction, or linked to the second group, namely the Kaduna group which split from the Jos faction. The Izala movement was established in fact in Jos and its headquarters are still in Jos. Today, followers of Sheikh Ismaila Idris have their national office at Sarkin Mangu, Jos. The Kaduna faction and its leaders are based in the same town as

\footnotetext{
${ }^{17}$ Literature on methods and approaches in the study of religion is diverse. For an overview on different perspectives dealing with this topic see e.g. Connolly (1999) as well as Whaling (ed. 1995).

${ }^{18}$ I am thankful to the Head of the Department of Religious Studies, Professor U. Danfulani who hosted me and introduced me to his colleagues but also for his assistance in all directions; I am also thankful to all staff of the department. Through Mallam Dawood Abubakar I had my first contacts with Sufi Sheikhs and Izala members in Jos. I really appreciate his valuable support and patience.
} 
well as in Kaduna. Leaders of the Izala movement can also be found in other northern states, though.

Being affiliated with Izala movement as a movement or as a religious organization doesn't require any initiation, ritual, official forms, or membership fees. The organization requires the acceptance of its doctrine and rejection of Sufism as basic elements of association. The same is true if a member decides to leave the movement. There are no requirements or restrictions. Affiliation or membership of ordinary people among Muslims in more than one Islamic group or organization is socially accepted and widely practised in Nigeria. I have often heard statements like, "when I was affiliated with the Tijāniyya," or "when I left the Qādiriyya," or "I am a member of the Izala movement Jos faction." In most cases, this kind of membership or affiliation has to do with the social environment of the person being interviewed. If a person grew up in a Sufi community, then it was plausible that he or she became a Sufi and the same thing is true if most family members are Izala adherents.

\section{Interviews and discussions}

During the first field research trip in 2006 and 2007, I conducted thirty-five interviews and five informal discussions with experts of Islam and other religions in northern Nigeria. At the very early stage of my research, I restricted myself to interviews with experts. I spoke to leaders from the Izala movement affiliated with the Jos or the Kaduna branches (sixteen interviews). I also interviewed seven Sufi leaders (two from Qàdiriyya and five from the Tijāniyya). In addition, twelve subjects were interviewed from different groups and religious orientations in order to understand their points of view on the Izala movement, Sufis and $\operatorname{shari}^{-} a$. Part of this group provided outsider perspectives as former Izala members or religious leaders who are related neither to Izala nor to Sufis. The most important thing during this fieldwork was to identify the actual leaders of the Izala movement and to interview them about the history of the movement as well their relationship to other Islamic groups, past and present. Their views are complemented by the views of Sufis as well as by ex-members of the Izala movement, but also by leaders from different doctrinal orientations (Salafi, neutral, shari ${ }^{-} a$ expert, etc.). All subjects were male. Concerning the five informal discussions, they were conducted at the University of Jos with scholars (Muslims and Christians) from the departments of Islamic, religious, and historical studies. ${ }^{19}$

During the second stay in the field, thirty-eight interviews were conducted (thirty-two with male subjects and six conducted by a female research assistant with six women in Jos). During this period of time, the viewpoints of ordinary Izala members in Jos were added to further interviews with Islamic scholars. Biographical interviews with members of the Jos faction of Izala (eight in Jos, one in Dutse) were conducted in addition to expert interviews in different local contexts of northern Nigeria (Gombe,

19 Discussions with Dr. Gwamna (Religious Studies), Dr. Yilpet (Theology), Professor Dahiru Yahya (Islamic Studies), Professor Sati Fwatshak (History). 
Gashua, Maiduguri, Dutse, Kano, Katsina, Kebbi, and Gusau). Interviews were conducted in either English or Arabic. Only in two cases were interviews conducted in Hausa with a simultaneous translation. Arabic interviews were transcribed and translated into English. During the first field research a voice recorder was used during the interviews. In many cases, my interview partners were sceptical about recording the interview and I decided to take notes only. During the analysis of the interviews, statements on the history of the Izala movement, reasons for the split of the movement, its relationship to Sufism or shari ${ }^{-} a$-related issues were repeated several times by different interviewees. For this reason, not all interviews are integrated into the present text. My selection of interviewees was related to the importance of the information and the position of the interview subject in relation to the Izala movement or other relevant groups.

\section{Observation(s)}

During my stays in Nigeria, I visited several mosques and institutions belonging to both the Izala movement and Sufi brotherhoods. These visits were not related to interviews or any academic work, but rather to build networks as well to develop a personal view about the religious field in northern Nigeria. Performing prayers was always an opportunity to meet people and to think about the views and differences reflected during the interviews by the different interview subjects. In some cases I interviewed Sheikhs in the mosque and during the interviews believers came to perform their salat (in Arabic: prayer) or practice their congregational obligation (Arabic: wazifa), for example. Besides mosques, I visited classes of the School for Higher Islamic Studies in Jos and a primary school in Kano (both belong to the Jos faction of Izala movement). In Gombe, I also visited the Izala headquarters linked to the Jos faction and had a unique opportunity to visit a hospital belonging to the organization.

\section{Material collected}

Besides the interviews, additional materials and sources of information were collected. I used the encounter with Nigerian academics to access the libraries of religious studies, history, and Islamic studies departments. These libraries were a treasure of unpublished material on Islam in northern Nigeria. They provided information on the Izala movement, Sufis, and other Islamic groups in the local context. Some BA-, MA-, and $\mathrm{PhD}$-dissertations relevant to my topic and found in Jos, Sokoto, and Kano were also consulted and collected. I also collected publications from the Izala branch in Jos, most particularly, pamphlets, books, booklets, and publications of leaders, such as published transcripts of Friday-sermons. The Izala faction in Jos has a shop in which all material related to the movement (sermons, seminars, meetings) are VHS-recorded and sold to their members as well as to the public. CDs and audio-cassettes of Izala- 
leaders (and others) circulate in the market. I have collected samples of this material as well material from libraries and bookshops in Jos and other towns in the north.

\subsection{The theoretical framework}

The rapid growth of the Izala movement in northern Nigeria was outstanding and has attracted the attention of scholars from different academic disciplines. ${ }^{20}$ The explanations for this development vary. An analysis of the whole situation in Nigeria in the 1970 s proposes that political, economic, and social disorder and uncertainty lead to the rise of new religious movements like the Izala movement. Such a development does not occur only in the Muslim context. ${ }^{21}$ The role of charismatic figures like Sheikh Gumi or Sheikh Idris and their call to reform Islam in Nigeria also played a crucial role in transforming the Izala movement into a mass-movement. On the one hand, nobody can claim that the Izala movement is the most influential Islamic organization today since we lack reliable statistical figures. On the other hand, we cannot deny that the Izala movement developed into a significant actor on the Islamic landscape alongside the influential and diverse communities of Nigerian Sufi brotherhoods. Both Qādiriyya and Tijāniyya are historically the two major actors in "Nigerian" Islam. Even today, places like Maiduguri, Kano, and Sokoto are Sufi centres par excellence. However, we are not in the position to offer a final overview of the different groups and orientations of Nigerian Muslims.

In my project, I do not try to develop a theory of religious organizations although I am dealing with a religious group from a sociological perspective. I am also not discussing whether the Izala movement is a religious "organization" and/or a religious "movement". ${ }^{22}$ I believe that the Izala movement fulfils the requirements of both: it started as a movement of a single charismatic person and developed into a modern organization. Thus, I use both terms interchangeably. Furthermore, I look at Izala movement's recent development(s) and aspects that have not been studied in academia or within a new religious field of $\operatorname{shari}^{-} a$ re-implementation.

Central for my analysis are the theories of Pierre Bourdieu, Harvey Whitehouse and Rodney Stark. Why these three approaches? There is something the three authors have in common: they are not defining religion or restricting their theories to a particular group or religious tradition. Their theories can be applied to various religions. In addition, none of these three theorists use data derived from an Islamic context. All three seem to offer a model for a better understanding of religious groups in general. I

\footnotetext{
${ }^{20}$ See my literature review above.

${ }^{21}$ New religious movements regularly appear and disappear in Christian and other religious contexts; for a good summary on religious movements in Africa in both Christian and Muslim contexts see Hackett (2011).

${ }^{22}$ I am thankful to Professor Achim von Open who directed my attention to this point during the BIGSAS Advanced Work in Progress Colloquium, Iwalewa Haus, University of Bayreuth, Germany, $3^{\text {rd }}$ December 2010.
} 
will implicitly use these theories to analyse and interpret the development of the Izala movement in the conclusion. I think that Bourdieu's terminology for instance offers an excellent tool not only for describing the Izala movement, but also the change(s) that occurred within it. ${ }^{23}$ Furthermore, the theoretical frameworks of Whitehouse and Stark generate new insights into the dynamics of the Izala movement as a religious phenomenon. In the following paragraphs, these theories are introduced.

Bourdieu applied to the Izala movement ${ }^{24}$

Steven Engler emphasizes that the French sociologist Pierre Bourdieu has recently been (re)discovered by scholars of religion and he expects a further growth of this tendency. According to his observations, a number of scholars, especially in the field of sociology of religion, are attracted by Bourdieu's theory and his terminology (Engler 2003: 445-446). This surprisingly late interest in Bourdieu's concepts by scholars of religion might be explained by the fact that he undertook research on religion only to a limited extent as David Swartz observes (Swartz 1996: 71). Bourdieu only published a study on French Catholic Bishops in 1982 and two articles on the sociology of religion in 1987 and 1991. Some key concepts of Bourdieu's theory are capital, habitus, field, and symbolic power. They are compatible with more than one academic discipline and applicable to culture, but can also be used in the context of economy, religion, or philosophy. Bourdieu's notion of capital is manifold (see Bourdieu 1986: 241-258). The most important are: economic capital, which can be converted into money and is institutionalized in property rights; cultural capital which is under certain circumstances related to economic capital, and its institutionalization is manifested in educational qualifications; and finally, social capital, which is based on social obligations and institutionalized in titles of nobility.

For my project the concepts of cultural and social capital appear important and appropriate. Thus, I want to explain both concepts in more detail. Concerning the cultural capital, Bourdieu differentiates between embodied, objectified, and institutionalized forms. By embodied he means the notion of culture or cultivation. This capital can be converted into habitus and "cannot be transmitted instantaneously" like money or property. It is acquired and depends on time, society, and social class. It is unequally distributed and needs power in order to be imposed and transmitted (Bourdieu 1986: 244-245). The objectified state of cultural capital is related to the first type (embodied)

${ }^{23}$ Ousmane Kane (2003) uses Bourdieu's theory in dealing with the Izala movement. It is interesting to show the changes in the religious and political "field" of Izala movement he has described. Big events in the history of the movement like the division and later on the shari ${ }^{-} a$ re-implementation are new elements in the history of Izala movement.

${ }^{24}$ Some aspects of my theoretical framework were presented at BIGSAS-Colloquium "Advanced Works in Progress", 4-5 February 2010, Iwalewa Haus, University of Bayreuth, Germany as well during the Workshop "Continuity and Change in the Religious Field: Perspectives from Africa, 12-16 July, 2010, Chair of the Study of Religion 1/BIGSAS of the same institution. I am thankful to all participants of both events for their comments and recommendations. 
and is "objectified in material objects and media, such as writings, paintings, monuments, instruments, etc." It is transmitted materially but also symbolically (Bourdieu 1986: 246-247). The last state of cultural capital, the institutionalized, is rather related to academic qualifications that give their holder a kind of "certificate of cultural competence". These qualifications are unequally distributed among people in a particular society and establish a system of values (Bourdieu 1986: 247-248).

If the cultural capital is more or less linked with the individual, the social capital is related to groups of people. Bourdieu also calls it "collectively-owned capital". Its volume depends on the networks of an individual and on his or her capital. It is based on the principle of "solidarity" and "durable obligations." A kind of "symbolic constitution" emerges from these and "recognition" (in the group) takes place. Production of social capital requires - according to Bourdieu - "an unceasing of sociability" and "a series of exchanges" in which recognition is "affirmed and reaffirmed." A group regulates its own rules internally and appoints a representative as a leader who enjoys symbolic power. ${ }^{25}$

The described forms of capital and people's habitus are to be found in every field of society (politics, religion, education, art, etc.). These various fields are not isolated from each other, and are based on symbolic power. In all fields, a struggle for this symbolic power takes place. These dynamics and the interactions between the fields constitute the habitus of a particular society. Bourdieu defines the way habitus works as "the source of a series of moves which are objectively organized as strategies without being a product of a genuine strategic intention - which would presuppose at least that they are perceived as one strategy among other possible strategies" (Bourdieu 1977: 73). Actors also produce and reproduce "objective meaning." Important for Bourdieu is the "orchestration" of the different meanings to produce a "common-sense world" on the basis of common practices. These actors come across as "similar" or "identical" experiences. The common babitus of these actors is then perceived as "immediately intelligible and foreseeable" and "hence taken for granted" (Bourdieu 1977: 79-80).

The production of habitus requires "mobilizers" (prophets, leaders) who master common codes and who can undertake "corrections" and "adjustments" (Bourdieu 1977: 81). The reproduction of babitus can take place as a result of an "inculturation" and "appropriation" through which "objective structures like language or economy can reproduce themselves". In the course of the development of a common babitus, a new form of capital emerges: the so-called symbolic capital. This type is characterised by Bourdieu as "the most valuable form of accumulation" and has to do with acknowledgment and prestige (Bourdieu 1977: 85). This capital is better called "symbolic violence" and is necessary because it is the "only way in which relations of domination can be set up, maintained, or restored". This "invisible" form - as qualified by Bourdieu - is "neither officially declared nor institutionally guaranteed". This power cannot be acquired by a distribution of economic capital. It is based on what Bourdieu calls "virtue" (Bourdieu 1977: 191-194),

${ }^{25}$ For more details on the concept of "cultural capital" see Bourdieu (1986: 248-253). 
The different types of capital as well as the construction and regeneration of babitus and the symbolic violence require an abstract setting. Bourdieu suggests the notion of field, characterised by its dynamics and based on particular rules, mechanisms and structures. The concept of field is located in many places in society. It can be a field of art, of economy, of politics or religion. Magnus Echtler, an anthropologist and scholar of religious studies from Bayreuth, offers a good description of what the notion of field means in Bourdieu's terminology. The metaphor of game summarizes the whole situation. In every game there are players playing and developing their skills to master the rules. The example given by Bourdieu is that of roulette. Playing the game means accepting its rules and regulations. This metaphor reflects a more important game, namely, the social game. This type of game is a long-term game that based on implicit regulations in a particular field and that depends on the players and their positions. This social game differs from roulette as formulated by Echtler: "But unlike roulette, where the result of the game is determined by chance, social games are always rigged: the actors who accumulate the highest amount in the right combination of capitalia will usually succeed" (Echtler 2008: 28). According to Bourdieu, a game requires a strategy that he defines as "(...) the product of a practical sense, of a particular social game" (Lamaison 1986: 112). Players differ in their capacity to play by using effective strategies and by adapting to new and/or different conditions in particular. As Bourdieu formulates it: "The good player, who is, as it were, the embodiment of the game, is continually doing what needs to be done, what the game demands and requires. This presupposes a constant invention, an improvisation that is absolutely necessary in order for one to adapt to situations that are infinitely varied. This cannot be achieved by mechanical obedience to explicit, codified rules (when they exist)" (Lamaison 1986: 112-113).

According to Echtler, Bourdieu develops his notion of habitus or his theory of practice respectively as an answer to "objective and subjective theories." According to his theory, the babitus is based on the experience of people in a way that it can be produced and reproduced (Echtler 2008: 25). The concepts of field, capital, and practice are interrelated. Echtler formulates it accurately: "All practices are strategic in the sense that interested actors compete with each other, make use of the capitalia at their disposal in order to enlarge their capital or improve their position within the field of practice" (Echtler 2008: 30). Habitus is dynamic and is based on actors' "unlimited capacities" to generate it (Echtler 2008: 31).

Since the re-implementation of shari $a$ in northern Nigeria in 1999, the relationship between Sufi-Brotherhoods and Islamic reform movements like Izala movement has been affected in a very profound way. It changed from violent confrontations to peaceful co-existence. These two groups reduced their long, on-going struggle over doctrinal questions. To elucidate this phenomenon and to put it into a theoretical framework I will use Pierre Bourdieu's notions of field, capital, habitus and symbolic power. Kane (1993 and 2003) uses Bourdieu's theory to describe the religious field in Nigeria and particularly the field in which the Izala movement was established. $\mathrm{He}$ 
agrees with Bourdieu's understanding of the notion of capital that symbolic capital in a particular field is more important than economic capital and identifies "accumulation" and "conservation" of capital as key concepts of that theory (Kane 2003: 20-23). For the "religious field" of northern Nigeria, Kane proposes the following five categories of capital: (1) non-formally certified cultural capital (exoteric knowledge and esoteric science-Sufism), (2) formally certified cultural capital or exoteric knowledge like a university certificate or mastery of Qur'ān, (3) economic capital (material wealth), (4) symbolic capital (fighters for the cause of Islam), and (5) social capital (supporters, clients, disciples, etc.) (Kane 2003: 21-22).

The applicability of Bourdieu's theory by Kane in the context of the Izala movement is summarized in the following: "An assumption of Bourdieu's field theory is that, in each field, one finds a struggle between the "newcomers" and the "established dominant actors." The strategy of each category of players (or their game) is determined by the quantity and the types of capital they possess (e.g., money, followers, prestige, knowledge, etc.). In all fields, established dominant actors controlling diverse sorts and substantial volumes of capital will tend to be very conservative in order to preserve the structure of the field - understood as 'the state of power relations among the agents and institutions engaged in the struggle [...] to defend the monopoly and keep out competition"” (Kane 2003: 227).

The category of "newcomers" is very important when it comes to the emergence of the Izala movement. This group is represented by the youth, women, and a new generation of entrepreneurs who supported the Izala movement from the beginning. Through the biographies of some actors of the Izala movement, Kane shows how capital was obtained and how it was converted within the Izala movement religious field into other forms, for instance: economic capital to a social or symbolic one. This change offers the movement an opportunity to set up its own ideology against the traditional religious institution. ${ }^{26}$

An important question arises here: what is the relevance of using the same approach with the same movement again? The answer is that since Ousmane Kane's research, the religious field has been entirely re-defined. The Izala movement has new leaders, the movement is divided into two major factions, and their discourse is different from the 1980s and 1990s. Even more important is the whole new setting, in particular, when we think of the re-implementation of shari' $a$ by the northern states. These new challenges affected the Izala movement politically, economically and religiously.

The Izala movement of today is faced with many challenges. The new religious and more precisely the Islamic religious field is different from the past. The Izala movement of today is divided between the Jos and Kaduna factions and both are contending for acknowledgement among their adherents. The Izala movement is also part of the Muslim community as a whole at a national level as the shari'a issue shows. The reli-

${ }^{26}$ For a brief summary on the application of Bourdieu's theory of field on the Izala movement see Kane (2003: 228-233). 
gious field in which the Izala movement is acting nowadays is different from how Kane described it. The setting he illustrated and in which the Izala movement evolved, has changed. During the time of Sheikh Idris, the establishment of a strong mass-movement with many followers was at the top of his agenda. The category of "newcomers" (youth, women, etc.) as well as of those who possessed an economic capital (merchants, for example) played an important role in the start-up phase of the Izala movement. Islamic preachers (Arabic: $d u^{\prime} \bar{a} t$, sing. $d \bar{a}^{\prime} i$ ) who joined the Izala movement-founder came with their cultural capital and assisted in the process of recruitment. The founder enjoyed loyalty and respect and the Izala movement was mainly focused on fighting Sufis and Sufism and attracting new adherents and followers.

Today the Izala movement is affected by internal strife and friction. The religious field is re-defined. The Jos-faction's leader, Sheikh Sani Yahya Jingir, a former student of the Izala founder and current leader of the Izala faction in Jos, is attached to the tradition of Sheikh Idris and defines all aspects of "being-an-Izala" in relation to the tradition originally established by Ismaila Idris. In Kaduna group, the two distinguished Sheikhs are Sheikh Yusuf Sambo and Sheikh Rabiu Daura. ${ }^{27}$ The Izala religious field in Kaduna is different from what the founder of the movement established. Defining Izala-identity internally and acting as a dynamic movement within the Muslim community of Nigeria are the new challenges that the Izala movement is facing today. These challenges are elaborated in the next chapters. ${ }^{28}$

The "modes of religiosity" theory

The "modes of religiosity theory" 29 of Harvey Whitehouse can also be a model for explaining the Izala development. This type of cognitive approach is new in religious studies and has again not been applied to an Islamic context. In his theory, Whitehouse is interested in religious experience and in explaining cognitive mechanisms in the transmission of religion or any religious ritual. This theory recognises remembering and motivation as crucial elements for any particular religion or ritual that wants to survive. Religious beliefs and rituals should be repeated and easily accessible to people. They must be meaningful for believers in order to be transferred from one generation to the next (Whitehouse 2004: 64).

Based on literature in psychology, Whitehouse analyses the notion of memory and divides it into two types: an implicit and an explicit one. By "implicit memory" he means "those things that we know without being aware of." For the explicit memory - which is more important for us - he distinguishes a short-term from a long-term memory (Whitehouse 2004: 65). The long-term memory is sub-divided into semantic

\footnotetext{
${ }^{27}$ Both Sheikhs Yusuf Sambo and Rabiu Daura are the leaders of the Kaduna faction of Izala movement that split from the founder Sheikh Idris.

${ }^{28}$ See chapter "Reform Islam vs. Sufism."

29 This approach is elaborated by the author in several of his publications, see for instance, Whitehouse (2004).
} 
and episodic. The semantic type reflects "knowledge about the world" and the individual is unable to remember the point in time of its adoption. The episodic type deals with particular events in life (death, war, etc.). According to Whitehouse, these types of memory are activated differently in what he calls "doctrinal" and "imagistic" modes of religiosity (Whitehouse 2004: 65). These two modes occur separately or together in a single religious tradition. For the doctrinal modes, frequent repetition of religious rituals, a long-term-episodic memory, religious leaders, hierarchy, and orthodoxy are important for a doctrine to survive. The imagistic mode of religiosity is characterised by its low frequency (initiation, for example) and its high emotional arousal: It does not need orthodoxy; it is hard to spread; and it appeals to episodic memory. ${ }^{30}$

In the case of the Izala movement, the doctrinal mode appears more applicable. Why is that so? We might get the impression that the Izala movement tends towards the doctrinal mode of religiosity while Sufism is the imagistic one. Since the establishment of the Izala movement in Nigeria a conflict emerged between the movement and the Sufis. Applying Whitehouse's theory, the conflict was a matter of doctrine, or a matter of doctrinal mode of religiosity to be more precise. The Qādiriyya and Tijāniyya Sufi brotherhoods have a long tradition in northern Nigeria and are well-established religious movements. They offer two different methods for drawing closer to God and their differences are doctrinal in nature. Through the intermediaries of sheikhs/saints, both of them construct a silsila, or a chain of knowledge going back to the Prophet and from him to God. In addition, they have their own practices generally established by the founder. In most cases, the founder of the order is associated with miracles. Adherents of the Tijāniyya for example claim that the founding Sheikh Ahmad al-Tijānī saw the Prophet in daylight. Qādiris also associate miraculous events with 'Abd al-Qādir al-Jīlānī. Tijāniyya and Qādiriyya followers last but not least believe in baraka, or benediction of the saint and both seek for tarbiyat al-nafs, or guiding of the soul. Tijānīs cannot affiliate with another Sufi order. When they are initiated by a muqaddam (in Arabic: introducer, initiator) they are asked to recite the daily litany and participate in special Tijānī congregational prayers. The hadra (in Arabic: communal gathering for dhikr, remembrance's prayer, and its associated liturgical rituals) on Friday is central to the doctrine of the Tijānī. Qàdiriyya also have their special prayers. They celebrate mawlid, the birthday of the Prophet. They commemorate their sheikhs, visit tombs, organize naming ceremonies for new-born babies, and participate in walima (in Arabic: gatherings for things like death, marriage or birth).

The Izala movement has questioned the relevance of Sufism and expressed doubt about its theological sources. For the Izala movement, Islam is only based on the Qur'ann, the sunna of the Prophet, and the tradition of al-salaf al-salitib - the pious predecessors. The movement does not believe in sainthood, miracles, or any existing intermediary between God and human beings. The Izala movement preaches tawhid (the oneness of God) and sees the message of the Prophet as the last revealed one. The

30 The two modes are explained in detail in Whitehouse (2004: 65-85). See also Whitehouse (2002: 293-315). 
movement was mainly established to fight bid'a and to "purify" Islam from all aspects of shirk and kufr (Arabic: non-belief).

The elements described by Whitehouse can be identified in these different religious groups. The presence of charismatic religious leaders is assured. The doctrines are preserved through repetition, and rituals are memorised by adherents and followers. The imagistic and doctrinal modes of religiosity are related to each other and a deeper analysis of this theory may give us an opportunity to better comprehend what is happening between Muslim groups in northern Nigeria. Historically, a doctrinal struggle among Sufi brotherhoods took place in the $19^{\text {th }}$ and $20^{\text {th }}$ centuries. To what extent this theory is applicable to Sufis groups as well to the Izala movement will be shown in the coming chapters.

\section{Religious market theory \& religious movements}

The history of the Izala movement has been characterized by a perpetual struggle against Sufis and Sufism. Through this conflict the Izala movement emerges as a conservative organization looking for its own identity among many other Islamic groups in northern Nigeria. When it was established, the Izala movement "changed" its course and concentrated more on education and da $w a$-activities than on attacking Sufism. The following chapters summarize the achievement(s) of the Izala movement over the course of its more than thirty years of history. This period of time is characterized by success and failure at different levels: internally and externally. The limits of these accomplishments are shown by the Izala movement itself. A crucial question is wether we can speak of success or failure of a religious movement that has been divided into two major factions? Furthermore, wether or not, and how the movement achieved its goals? In order to understand the limits of the success or failure of the Izala movement, the religious market theory is applied since it offers a model of understanding of growth and decline applicable to any religious movement.

In the religious context, the religious market theory and the notion of a religious economy was developed by the sociologists of religion Rodney Stark and William S. Bainbridge in the mid-1980s. This approach to explain the phenomenon of religion with a terminology usually used in economics is discussed extensively and controversially. The so-called "religious economy" is a religious activity that can be found in any society - according to Stark and Finke (2000). In a "religious market" there are "potential adherents, a set of one or more organizations seeking to attract or maintain adherents and the religious culture offered by the organization." (Stark and Finke 2000: 203). Religious organizations are compared to "firms" competing for members. These firms are differently organised and have various regulations and logics. Lay people are seen as consumers following their demands and having the choice between several offers. Religious leaders are the "religious producers" who produce religious goods for the needs of their clientele. They make efforts to satisfy the needs of their followers, advertise their products, and compete with others in order to protect their adherents and 
gain newcomers. The religious market needs to be pluralistic and all "religious firms" have the opportunity for marketing their ideas. This plurality depends on the number of "firms" existing in a particular religious market. This market generally consists of "niches", which are "market segment[s] of potential adherents sharing particular religious preferences (needs, tastes, and expectations)" (Stark and Finke 2000: 284).

Stark conducted his field research in the U.S.-American society and most of his studies are generally located within a Christian context. He published extensively on the notions of "God" and "monotheism", just to mention some. His theory could be applied universally to any religious movement. He defines religious movements as "social enterprises whose primary purpose is to create, maintain and supply religion to some set of individuals" (Stark 1996: 134). According to Stark, if a religious movement wants to achieve a certain level of success, certain requirements must be fulfilled. He summarizes these requirements in the following points:

a) New religious movements are likely to succeed to the extent that they retain cultural continuity with the conventional faith(s) of the societies in which they seek converts.

b) New religious movements are likely to succeed to the extent that their doctrines are non-empirical.

c) New religious movements are likely to succeed to the extent that they maintain medium levels of tension with their surrounding environment - they are strict, but not too strict.

d) New religious movements are likely to succeed to the extent that they have legitimate leaders with adequate authority to be effective. Adequate authority requires clear doctrinal justifications for an effective and legitimate leadership; authority is regarded as more legitimate and gains in effectiveness to the degree that members perceive themselves as participants in the system of authority.

e) Religious movements will grow to the extent that they can generate a highly motivated, volunteer, religious labour force, including many willing to proselytize.

f) Religious movements must maintain a level of fertility sufficient to at least offset member mortality.

g) New religious movements will prosper to the extent that they compete against weak, local conventional religious organisations within a relatively unregulated religious economy.

h) New religious movements will succeed to the extent that they sustain strong internal attachments, while remaining an open social network, able to maintain and form ties to outsiders. 
i) Religious movements will continue to grow only to the extent that they maintain sufficient tension with their environment i.e. they have to remain sufficiently strict.

j) Religious movements must sufficiently socialize to young people so as to minimize both defection and the appeal of reduced strictness (Stark 1996: 136-144).

Stark regards religious movements as things that appear and disappear depending on the conditions of any given society. They evolve either from an old religious tradition or can be initiated through a person who invents them. These movements share one feature: all of them bear the risk of failure. As Stark aptly puts it:

This year, hundreds of new religious movements will appear on earth. Some will be formed by disgruntled members who withdrew from older religious bodies. Others will be born because someone created or discovered new religious culture and convinced others of its authenticity. However, whatever their origins, virtually every new group will have one thing in common: eventual failure (Stark 1996: 133).

The approach of Stark goes further and applies the so-called "rational choice theory" to religion. This theory is well-known in economics and to some extent in sociology and a few other disciplines. From an economic point of view, individuals try to maximize benefits on the one hand, and to minimize their expenses, on the other. Economists observe that market mechanisms depend on daily decisions made by "consumers and producers (who) rationally calculate profit and loss" (see Spickard 1998: 99-115). In the context of religion, the theory of rational choice combines market behavior with individual religious action (Spickard 1998: 99). As mentioned above, religious institutions are considered "firms" offering different products and competing against each other for a monopoly within the market. Consumers (or adherents) have the choice to define their needs and calculate their benefits.

When it comes to Islam, the religious market theory seems to draw the attention of scholars. The sociologist of religion, Massimo Introvigne, applied it to Islam in Turkey and few other Muslim societies (see Introvigne 2005: 1-23). He focuses on the concept of "niches" - developed by Stark - and its relationship to "strictness". Religion is often perceived to be stricter when its symbolic costs are higher and when its members are expected to believe and behave in more traditional and conservative ways than society at large" (Introvigne 2005: 3). Introvigne developed a model where he classified Islamic groups into five categories: ultrastrict (Al-Qāंida for e.g.), strict (like Brotherhoods, Wahhābism), moderate-conservative (Naqshbandiyya Sufi brotherhood), liberal (Ba'ath Party) and ultraliberal (Islamo-Marxism). Following this categorization, Introvigne designed a "Model of the Turkish Religious Market" and proved that Stark's theory can be validated empirically in an Islamic context. Introvigne's in- 
sight generates the question of the applicability of the religious market theory vis-a-vis the Izala movement in northern Nigeria. Does it help to understand the enormous growth of the Izala movement during its first two decades of existence? Does it also explain a potential failure of the movement?

If we apply the religious market theory to the north Nigerian context, we see that the "religious market" in which the Izala movement operates is "pluralistic." In addition to Muslims and Christians, adherents of African Traditional Religions are also part of the general religious landscape of Nigeria, and there are sub-categories in each of these communities. Among Muslims, the two major Sufi brotherhoods (Qādiriyya and Tijāniyya) had a quasi-monopoly because of their well-established tradition in northern Nigeria. Sufi brotherhoods made big efforts to win new affiliated members in their turuq (Arabic: brotherhoods). The theological and, to some extent, political debates came to an end with the appearance of the Izala movement at end of the 1970s (see Loimeier 1997a). 



\section{Nigeria's religious landscape}

This chapter serves as a historical background to the current development in the country. It gives an overview of the spread of both Christianity and Islam in Nigeria. The focus here is on Islam: the chapter highlights the establishment of the Qaadiriyya and Tijāniyya Sufi brotherhoods, it gives an insight into the Britisch colonial policy of "indirect rule," and it finally document the rise of anti-Sufism during the post-colonial period.

\subsection{Christianity in Nigeria}

Unlike Islam, Christianity found its way to Africa's most populous country through missionaries. The first "sporadic" activities of Christian missionaries in the southern part of Nigeria took place in 1515 . In the early sixteenth century, a few Christian missionaries like Gregorio Lourenço and Afonso Anes were in Nigeria but without much success (Isichei 1983: 318). The following attempts to Christianize Nigeria suffered from the same setback. The historian Toyin Falola explains this fact in three basic elements: slavery and trade of slaves at that time, lack of missionaries who were able to undertake proselytization, and lack of finances. The activities of missionaries were intensified at the end of the nineteenth century in the south of the country. Christian 
Ramzi Ben Amara: The Izala movement in Nigeria

organizations (esp. Protestant and Catholic ones) from Europe and North America were interested in a "great missionary expansion". Some introduced Christianity as an alternative to slave trading and found a way to enter the West African country (Falola 1999: 40).

To some extent, this mission can be interpreted as an answer to the presence of Islam that has a long tradition in the country. The Christian missionaries opted to spread Christianity amongst Africans themselves. This strategy is known as "native agency." It reduces costs, protects non-Africans from diseases, and especially mobilizes Africans to propagate Christianity in their local regions (Falola 1999: 41). When Slavery was abolished, many former slaves from Sierra Leone, Cuba, and Brazil returned to Nigeria after 1830. They were considered by Europeans to be potential missionaries who could expand Christianity. Furthermore, they were essential elements needed in the education and health sectors. In 1840, a British expedition, The Niger Mission, came to the Niger River area. This organization had a religious background, but tried through trade activities to come in contact with local leaders. This strategy can be considered to be one of the most successful activities of the Church Missionary Society (C.M.S.) and led to the conversion of many people in Nigeria. ${ }^{31}$ The C.M.S. was successful especially among the Yoruba in the south (Lagos, Abeokuta, Ibadan und Ilesa), and in the Delta Region. In that area, Methodist and Catholic Churches were established. Catholicism spread among the Yoruba and the Ibo. The success of Christian missionaries in southern Nigeria can be explained by the fact that Yoruba-leaders expected that "the missionaries would help them win their wars and procure arms and missionaries" (Falola 1999: 42). Concerning the Delta Region there were more economic interests behind the success of the missions. Local traders were interested in contact with Europeans. This explains why leaders in those areas allowed the establishment of Christian schools in their territories.

The spread of Christianity in southern Nigeria was also linked to the fact that people associated reform with Christianity. For the local leaders of that time, Christian missions offered solutions to their problems. Missionaries were involved in local politics and played the role of intermediaries; for instance, missionaries were responsible for putting an end to the Yoruba confrontations. This kind of role brought missionaries more respect and confidence from local rulers, but also amongst common people. In addition, missionary schools played a crucial role in converting people: "in many places, the church and the school went together" (Falola 1999: 42-43). When Christianity in Nigeria gained a foothold, African religions were increasingly characterized as symbols of "paganism". Traditional deities, priests, and temples were rejected. Tra-

\footnotetext{
${ }^{31}$ Falola points out the success of this mission through the activities of Samuel Ajayi Crowther, a former slave known as the "hero of the Niger Mission." This man is the first African Bishop of the C.M.S. See Falola (1999: 41).
} 
ditional values were not respected and were largely replaced by new Christian norms and values (Falola 1999: 44). ${ }^{32}$

Christianity in Nigeria passed through the southern region before it spread to other parts of the country. By the end of the $19^{\text {th }}$ and $20^{\text {th }}$ centuries and through the activities of the Sudan Interior Mission (SIM) and Sudan United Mission (SUM), several Christian missions were initiated in the Middle belt region and spread from there to the north. This enterprise was interrupted by the coming of the British who restricted missionary activities in the north. "Nigerian Christianity" - as Klaus Hock calls it - became more fastened ("befestigt") through the independence. From that time, Christian missions intensified in the north. Klaus Hock calls it the "strategic counter-invasion" ("strategische Gegeneroberung") of Islam. In addition to the SIM, the SUM intensified their missions. Conversely, the Catholic Church, the Methodist, the Church of Brethren Mission (CBM), the Qua Ibo Mission, and the United Missionary Mission (UMS) undertook the same project (Hock 1996: 46). Klaus Hock observes that the Christian Churches in northern Nigeria had no split like what happened in the south of the country with the establishment of African Independent Churches (1996: 48). ${ }^{33}$ The structure of the missions, especially their concentration on education, led to their success among the African population of Nigeria. Christian missions started in the south of the country and succeeded in recruiting African missionaries familiar with their local communities. At a later stage, European missionaries themselves intensified their activities in all directions. Concerning northern Nigeria, missionary activity was restrained by the policy of "Indirect Rule" of the British before entering into the post-colonial period.

\subsection{The history of Islam in Nigeria ${ }^{34}$}

The territory of the Federal Republic of Nigeria and its political borders are products of the colonial era. Nigeria as a state did not exist before the coming of the British. The first contact between the population of what is today known as Nigeria and Islam happened during the eighth and ninth centuries through tradeing caravans coming from North Africa. ${ }^{35}$ The German scholar of religion and theologian Klaus Hock describes this period as "superficial Islamization" ("oberflächliche Islamisierung"). This first contact took place especially in the north-western part of the territory. Concerning

\footnotetext{
32 Isichei (1983: 326) confirms that both the Catholic and Protestant Mission condemned aspects of traditional religions.

${ }^{33}$ The absence of such a split does not mean that African Independent Churches are not to be found in northern Nigeria. Churches like Celestial Church of Christ and Aladura are well-established, especially in big towns of the north, see Hock (1996: 49).

34 This chapter is based on my unpublished MA dissertation (Ben Amara 2005).

35 The majority of these traders were Ibadites belonging to Kharijite-Islam. This group of people was marginalized in both West Africa and North Africa. Instead of this Islamic denomination, Sunni Islam became dominant. For more details, see Hock (1996: 14).
} 
the north-eastern area located near Lake Chad known as Kanem-Bornu, Islam came during the eleventh century with traders from Egypt and Fezzan (Libya). Mostly, Islam attracted elite members of the society and this remained the case for a long time. After a period of weakness during the sixteenth and seventeenth centuries, Islam became a "religion of the masses" in that area (Hock 1996: 15). ${ }^{36}$ In the Hausa states, the Algerian Islamic scholar and reformer 'Abd al-Karìm al-Maghili played a crucial role in the process of Islamizing the region. Islam was spread by this scholar at the end of the fifteenth century and was adopted by Hausa kings from the beginning of the sixteenth century. Al-Maghilli's influenced the masses as well the Hausa kings who adopted his ideas and suggestions for reform. ${ }^{37}$

The history of Islam in Nigeria remains incomplete if the Sokoto Caliphate of the $19^{\text {th }}$ century and the jih $\bar{a} d$ movement of Usman dan Fodio are not mentioned. The Sokoto Caliphate was one of the important kingdoms in West Africa. It spread beyond the current borders of Nigeria. Usman dan Fodio was from the ethnic group known as the Fulani. He was born in Gobir in 1754 . He received a traditional Islamic education, and at the age of twenty, he was already a student, a teacher, and a preacher. ${ }^{38}$ Dan Fodio moved from place to place throughout Hausaland and attracted many followers along the way. He criticised prevalent practices in that area and considered them to be un-Islamic innovations (bidac). This attitude was also supported by his adherents. The well-known jihäd of Usman dan Fodio started 1804 and was interpreted differently. Some scholars interpret it as "holy war" as well as Islamization of north Nigeria and neighbouring areas. The historian Jamil Abun-Nasr considers it as a "militant answer" vis-à-vis the leadership of that time. According to Abun-Nasr, the jibād started when the King of Gobir's soldiers attacked the community of 'Abd al-Salām, a former student of dan Fodio, and captured some of his people (Abun-Nasr 1993a: 3).

The struggle against 'Abd al-Salām's community and the liberation of prisoners from among his community were interpreted by the Hausa king as an offensive against his authority. As a result, he ordered dan Fodio to leave that area. The answer was an "Islamic revolution" - as Abun-Nasr describes it. Usman dan Fodio called his allied people from among the Hausa, Tuareg and Fulani and mobilized them for war.

\footnotetext{
${ }^{36}$ Hock mentions the establishment of the Kingdom of Kanem-Bornu in the fourteenth century in the Lake Chad area as a "stabilizing factor" of the region at that time. This stability explains the spread of Islam to the masses. Hock compares the Islamization of Kanem-Bornu with a model of Islamization in West Africa suggested by Forstner (1987). This Islamization model differentiates between a period of "Islam as religion of minority" (ninth-twelfth centuries), "Islam as religion of the elites" (twelfthsixteenth centuries), "Islam on the way of being the religion of the majority" (seventeenth-eighteenth centuries), and finally the period of "jihād-movement" (eighteenth-nineteenth centuries). According to Hock, Forstner's model is applicable to Kanem-Bornu but only to its third level.

37 For detailed information on the life and influence of al-Maghīin in Nigeria see Batran (1973) as well as Hunwick (1974). For the expansion of Islam in Hausaland see Meunier (1997). According to Hock the Islamization of Hausa land took place later than Kanem Bornu. Islam came to Kano through traders from Mali during the fourteenth and fifteenth centuries (Hock 1996: 16).

${ }^{38}$ For the life of Usman dan Fodio see El-Masri (1963).
} 
This is how the jibäd started and spread in different directions. As a result, the Sokoto Caliphate was established and became the dominant authority in that region especially at the beginning of the $19^{\text {th }}$ century. ${ }^{39}$ After the death of Usman dan Fodio in 1817, Muhammed Bello, his son, took over as Caliph until 1837 (Abun-Nasr 1993a: 3-4). The Sokoto Caliphate developed into one of the strongest empires in West Africa. The jibād resulted in victory over the Hausa-states, but also to the Islamization of new areas. Klaus Hock mentions that the borders of the Caliphate in the year 1840 extended from north Cameroon in the east, Illo in the west, as far as Adrar in the north, and Yorubaland in the south (Hock 1996: 18).

As a summary of the spread of Islam in Nigeria one can say that the first contact happened through trade caravans from North Africa. After that, Islam had begun in the region as the "religion of rulers" before it became the "religion of the masses". AlMaghilli's influence during the fifteenth century and the establishment of the Sokoto Caliphate in the nineteenth century can be seen as basic elements in the spread of Islam in northern Nigeria as well as in West Africa generally. The Sokoto Caliphate started as a reform movement led by Usman dan Fodio and lasted for about one hundred years. It affected not only northern Nigeria, but the whole region. By the end of the nineteenth century, the Caliphate entered a period of weakness, which eventually lead to its decline. The coming of the British put an end to the hegemony of the Sokoto Caliphate. In 1900, northern Nigeria was declared a British protectorate. The policy of "Indirect Rule" and a project of reforming Islamic law were both part of the British strategy to control the north until 1960, when Nigeria gained its independence.

\subsubsection{The Sufi brotherhoods}

The landscape of Muslim groups and orientations in Nigeria is complex. In this chapter, only a few of them are introduced. The Qãdiriyya is one of the oldest Islamic Sufi brotherhoods in West Africa, and it played (as did the Tijāniyya) a crucial role in spreading Islam in that area. It is known that Usman dan Fodio was a follower of the Qãdiriyya. The Tijāniyya came later to Nigeria and established itself as an anti-pole to the well-established Qādiriyya. Especially in the pre-independence period, affiliation to one of these orders had clear political implications - as shown by Loimeier (1997a).

\section{The Qādiriyya}

Studying the Qādiriyya (or any other Sufi order), its founder or sheikhs, writings, doctrines, or its development in a particular context deserves more than one book. The brotherhood is still powerful in matters of followers and influence on the northern Nigerian religious landscape, and even in the politics of the country. According to

39 For a detailed description of the establishment, spread and structure of the Sokoto-Caliphate see Last (1967). 
Abun-Nasr, ${ }^{40}$ the origins of the Qādiriyya date back to the thirteenth century. This țarìqa is named after 'Abd al-Qādir al-Jīlānī (1077-1166). 'Abd al-Qādir al-Jīlānī established himself in Bagdad as a preacher and a scholar of Sufism. He was influenced by Hanbali teachers and by the Hanbali School of law, but at the same time by Sufi Sheikhs. The madrasa (in Arabic: school), in which 'Abd al-Qādir al-Jīlānī acted as Sheikh continued to exist as an Islamic centre for teaching even after his death. He was even buried there. Abun-Nasr speaks of three basic writings of the Sheikh: the first one entitled Futüh al-Ghayb (in Arabic: The Revelation of the Unseen), is where his views on Islam and Sufism are reflected; the second book al-fat bl al-rabbanni (in Arabic: The Sublime Revelation) is a collection of some his preaching from the year 1151 when he called his followers to "trust God" and obey his "commands"; and the third one, al-ghunya li-talibi țariq al-haqq (in Arabic: Sufficient Provision for Seekers of the Path of Truth), largely deals with jurisprudence, explanation of the names of God, and mysticism. Abun-Nasr summarizes the important points in 'Abd al-Qādir al-Jìlānî's writings in the following topics: fighting against the self, the idea of wilaya (in Arabic: sainthood) and its difference from prophet-hood, and the Sufi Sheikh as a guide for his followers (Abun-Nasr 2007: 86-91).

The silsila (in Arabic: chain) of 'Abd al-Qādir al-Jìlānī can be traced back to both maternal and paternal sites through Hassan and Hussein, then to the Prophet's daughter Fatima, and finally to the Prophet himself. This affiliation gives 'Abd al-Qādir alJìlāni the position of being a qutb (in Arabic: pole, axis). Believing in the Sheikh as ghawth (in Arabic: savior) and reciting his poem (al-ghawthiyya) eleven times daily is considered to be beneficial for any Qãdiriyya adherent. Those who trust the Qādiriyya founder do not have to fear "divine punishment." The "spiritual" connection of the Sheikh is added to his karämāt (in Arabic: miraculous acts), which confirm his position as qutb al-awliya (in Arabic: pole of all saints). Legends attributed to 'Abd alQādir al-Jìlānī such as fasting when he was a small child are narrated by Qādiriyya hagiographers.

The Qàdiriyya doctrine spread throughout many countries in the Arab world and beyond during the fifteenth century. In the same period, it reached both East and West Africa. The Sufi order built a network of branches in many places associated with different Sheikhs. The Sufi order does not have any "centralized spiritual leadership" or fixed guidelines - as Abun-Nasr describes it. It's dhikr (in Arabic: remembrance) is part of its practices but is not fixed according to specific rules. In addition, there are prayers for praising God attributed to 'Abd al-Qādir al-Jīlānī. Their selection and frequency are left to the Qādiriyya-Sheikh. ${ }^{41}$

\footnotetext{
40 See Abun-Nasr (2007).

${ }^{41}$ Abun-Nasr (2007: 92-96). The author provides a good summary of Qādirī doctrines and practices. The son of the Qādiriyya founder, Abdurrazaq, seems to play an important role in compiling his father's ideas and writings. The karāmāt (Arabic, Singl. karäma), legends of the Sheikh are described by other Qādiriyya writers.
} 
In the case of Nigeria, the Qãdiriyya came to Borno, in the north east of the country, through the Sahara trade during the twelfth and thirteenth centuries (Qadri 1981: 52). The order contributed to the expansion of Islam in that area, as was the case in West Africa as a whole. Usman dan Fodio was affiliated with the Qādiriyya or "was not devoid of mystical experience,” as Qadri emphasizes (1981: 53). The Qādiriyya affiliation may have helped the Jihadists around Usman dan Fodio in their war. Dan Fodio himself introduced many followers to the tariqa. Thematically, dan Fodio wrote on Sufism and Sufi topics. After his death, many miracles were attributed to dan Fodio himself. Also, Abdullahi, dan Fodio's brother, as well Muhammad Bello, his son, were members of the Qādiriyya. "The leaders of the Sokoto jibād were not only Sufis but shuyūkh (pl. of sheikh) of Qādiriyya who encouraged their followers to lead a pious life and endeavour to seek communion with God" (Qadri 1981: 63). ${ }^{42}$

\section{The Tijäniyya ${ }^{43}$}

The Tijāniyya Sufi brotherhood is named after Sheikh Ahmad al-Tijānī(1737-1815), a Sufi scholar from Ain Madhi in Algeria. The founder of the order traced his silsila of ancestors through Hassan, who was the son of the Prophet's cousin Ali, to the Prophet. Sheikh Ahmad al-Tijānī studied in, among others, Fez, Morocco, and was affiliated with different Sufi orders. He was even affiliated with the Qàdiriyya. He lived for a while in Tunis, moved to Cairo and then to Mecca. He spent the last stage of his life from 1785 until his death in Fez. In 1800, he initiated the building of his zāwiya (in Arabic: Sufi lodge) in Hawmat al-Blida (Abun-Nasr 1965: 15-22). Apart from North Africa, the presence of the Tijāni țariqa in West Africa nowadays, and particularly in Senegal and in northern Nigeria, cannot be ignored.

Sheikh Tijānī did not leave a book or manuscript in which his doctrine or world views are documented. This gap was filled by his companions 'Alī Harāzim who wrote jawābir al-máān i [...] (in Arabic: Gems of Indications and Attainment of Aspirations in the Overflowings of Sīdī Abil 'Abbās Tijānī), Ibn al-Mushrī who authored kitāb al-jāmi' li-l''ülum [...] (in Arabic: The Absolute in What Has Separated from the Sciences) and finally Muhammad al-Ṭayyib al-Sufyānī who wrote kitāb al-ifäda al-aḅmadiyya (in Arabic: Profit to the Seeker of Eternal Felicity) (Abun-Nasr 1965: 24).

The Tijāniyya founder considered himself the "pole of the poles" and the "seal of the Muhammadan saints." He was influenced by Ibn al-'Arabī, a very important Andalusian Sufi scholar and philosopher of the twelfth and thirteenth centuries. $\mathrm{He}$ enjoyed a luxurious life and this explains the Tijāni stance on wealth and asceticism.

${ }^{42}$ For more details on the Qādiriyya in Nigeria see Qadri (1981: 53-63).

${ }^{43}$ There are numerous publications on the Tijāniyyya Sufi order, see e.g. Triaud and Robinson (eds. 2000) and Tal (1991). For the Tijānīyya Niassiyya branch as well for the life of Ibrahim Niasse see the work of Seesemann (2004). As a general overview, I rely on the standard publication of Abun-Nasr (1965), for the Nigerian case see the PhD thesis of Qadri (1981). 
The Sheikh claims direct communication with the Prophet and to have received the teachings of the order from him. This connection confirms the authenticity of the order and the origin of the teaching of the Tijāniyya. Followers of this brotherhood are not allowed to join other Sufi orders or visit tombs of other, non-Tijānī saints (AbunNasr 1965: 28-49). Being affiliated with the Tijāniyya also means the recitation of the wird (in Arabic: litanies of the order), practising the so-called wazifa (in Arabic: office) at a particular time, and participating in the badra (Abun-Nasr 1965: 50-51). ${ }^{44}$

The Tijāniyya was initiated in West Africa through Mauritania by Sheikh Muhammed al-Hāfiz (1759-1830). From there it spread to Senegal through al-Hājjj 'Umar Tall (1794-1864). He was not only the Caliph of Ahmad al-Tijānī, but also an Islamic scholar and political leader. He visited Nigeria in 1826 on his way to Mecca and married a daughter of Muhammad Bello's, the son of Usman dan Fodio. From 1831 al-Haajj 'Umar Tall stayed in Sokoto for six years. During that time, the Tijāniyya expanded throughout what is now Nigeria and beyond. The Tijāniyya became an influential Sufi order in West Africa, especially after the jibād-movement of al-Hājj 'Umar against the French colonial expansion in the mid-1850s (Qadri 1981: 39-51).

In Nigeria, the advent of the Tijāniyya is related to al-Hājj 'Umar's visit to the country, although some views confirmed the presence of this Sufi order in Kano and Borno as early as the time of Ahmad al-Tijānī, the founder. Al-Hājj 'Umar Tall contributed to the spread of the brotherhood as he initiated many people to it (Qadri 1981: 64-66). During his stay in Sokoto, he seems to have initiated Muhammad Bello to the Tijāniyya. However, this claim is still controversial. ${ }^{45}$ Furthermore, the initiation of many people to the Tijāniyya in different parts of the north (especially in Zaria, Kano, Borno, and Sokoto) contributed to its spread. This resulted in a struggle for hegemony between it and the well-established Qādiriyya, particularly in the late nineteenth century and even during the colonial era. ${ }^{46}$

\footnotetext{
${ }^{44}$ A Tijānī-wird is practiced twice every day and it consists of repeating "astaghfiru Allah" (asking Allah for forgiveness) one hundred times, pronouncing the so called șalāt al fätiḥ one hundred times, and reciting the bailala (there is no God, but Allah); The so called salät al fätił is controversial and its recitation is equivalent to 6000 times of a Qur'ān-recitation. When it comes to wazifa which is practiced at least one time daily in congregation, it consists of repeating the formula "astaghfiru Allah al-'Azim lā Ilāha illa huwa al-hay al-Qayyūm” thirty times, performing șalāt al-fātị̣ fifty times, repeating the hailala one hundred times, and finally the so-called jawharat al-kamāl (a Tijānī formula) twelwe times. 45 The debate whether Muhammad Bello was a Tijānī or not was debated by many scholars in and outside Nigeria. One cannot deny the influence of al-Hāijj 'Umar Tall on Dan Fodio's son. Muhammad Bello was also inspired by the Tijānīyya in some of his writings. See Qadri (1981: 66-72).

${ }^{46}$ See more details on the Tijāninyya-Qādiriyya struggle as well on the attitude of the British to the Tijānīyya in Qadri (1981: 81-106).
} 


\subsubsection{Indirect rule ${ }^{47}$}

The colonial occupation of Nigeria started in the south during the second half of the $19^{\text {th }}$ century. Lagos and its hinterland became a British protectorate in 1867 . The expansion to the north occurred during the first years of the twentieth century after a period of weakness of the Sokoto Caliphate at the end of the nineteenth century. According to Klaus Hock, Muslims reacted to the British in three different ways: some Muslims reacted with a kind of hijra (emigration) according to the example of the Prophet who migrated from Mecca to Medina; some 'ulamä' in Sokoto seemingly accepted the presence of the British but in fact practiced an "inner-emigration"; and the third group of Muslims preferred military confrontation (Hock 1996: 22).

The British administration was aware of the fact that invading such a vast territory like modern-day Nigeria would be very difficult. The obstacles seemed insurmountable, especially in light of the absence of an appropriate number of British officers, adequate finances, and necessary military capacities. ${ }^{48}$ Thus, they divided the country into northern and southern regions. They designed their approach of "indirect rule." This policy was especially formulated for the northern region. The British learned from the history of Islam in northern Nigeria that intervention in Islamic affairs is risky. Because of that they guaranteed Muslims that they could keep their old structures of authority. The first British Governor in Nigeria, Lord Frederick Lugard, promised Muslim rulers that they could keep their system of education and their Islamic courts. Furthermore, he prohibited Christian missionary activities in the north without prior agreement of northern rulers (Hock 1996: 23).

The British implemented "indirect rule" in Nigeria as their way of colonial domination. For Michael Crowder the way Britain ruled in Nigeria became exemplary for other British colonies (see Crowder 1964: 197-205). The policy stipulates that British officers serve as advisors for native rulers and allowed them to interfere in local decisions. Local governments based on "single executive authority" or a "council of elders" were supported by the British to continue acting as such. Lord Lugard acted until 1906 as first High Commissioner of the Protectorate of northern Nigeria, between 1912 and 1914 as the Governor of the two Nigerian protectorates, and finally from 1914 to 1919 as the Governor of the amalgamated Colony of Nigeria, which relied in northern Nigeria on the emirs' authority to govern this vast region. As part of his plan he suggested changing the system of taxation as well as modernizing the administration in general (Crowder 1964: 198). ${ }^{49}$

\footnotetext{
47 This policy of Indirect Rule practiced in British colonies was developed by Lord Lugard, former Governor in Nigeria and high-ranking colonial officer in other British colonies. The theoretical dimensions as well the applicability of this approach are explained in detail in Lugard (1965).

${ }^{48}$ Isichei mentions that the British administration lacked officers, soldiers and especially monetary resources to be able to control the Nigerian territory. Their strategies consisted then of using African soldiers to fulfill this task (Isichei 1983: 380).

49 Crowder mentions that Sir Donald Cameron, who served in Tanzania as governor was inspired by Lugard's policy in Nigeria. When he came to Nigeria (Sir Cameron), where he took the same position
} 
These reforms changed the status of the emirs within the political power structure. They were originally allies of the Sultan of Sokoto. After the establishment of indirect rule, they came under the supervision of the British administration and had to collect taxes in its name. They retained up to seventy percent of money collected from taxes to finance their own native administration. "Indirect rule" was applied in the north and suceeded because of the pre-existing political structure of authority. In other parts of Nigeria, like the east, it was hardly applicable. British political officers stayed for a long time in their position and worked as advisories to the local chieftaincy. They also adapted to the needs of their administration; for example, those who learned languages were often promoted..$^{50}$

This "indirect rule" policy was a necessity for the British administration because only a few officers (thirty-one, to be exact) were sent from London to the protectorate in Nigeria. ${ }^{51}$ The British took advantage of the ethnic factor in the north and at the same time recognized the attachment of the population to the emirs. From a historical perspective, Obaro Ikime speaks of two reasons that led to the establishment of "indirect rule." On the one hand, Lord Lugard legitimated the British occupation over the Fulani and Hausa emirs by comparing it to the Fulani occupation over the Hausa during the jibād of Usman Dan Fodio. On the other hand, those emirs who died or fled their territories were replaced by new ones appointed by the British. Their appointment took into consideration their acceptance within the local communities as well as their intention to cooperate with British officers who represented the British High Commissioner and the Governor, respectively. As exchange for their loyalty, which manifested itself in collecting taxes, building roads and establishing "good governance," the British promised not to intervene in religious affairs (Ikime 1970: 6-7).

In 1914, the amalgamation of Nigeria was declared, and indirect rule was extended to the south of the country. This situation was not an easy task. The southern parts of the colony lacked clear structures of "traditional rulers" which was not the case in the north. ${ }^{52}$ The reason for the centralization of the protectorates was economic in nature. It happened under the governorship of Lugard. The well-established direct taxation system that worked well in the north failed in the southern part of the country. Falola and Heaton explain the British economic interest in three main points: first of all, expanding Nigerian commerce; second, introducing an economy based on UK currency;

\footnotetext{
between 1931 and 1935 he was surprised by the level of independence of the northern Emirates that developed a kind of "Indian-style native states".

${ }^{50}$ Crowder distinguishes between the French and the British in dealing with their former colonies. The French choose a policy of "assimilation" and the British that of "indirect rule" (Crowder 1964: 203-205).

${ }^{51}$ See Ikime (1970: 8): The author speaks of forty-two officers approved by the British government in London, but only thirty-one were appointed in Nigeria. In fact, many of them were not able to work because of diseases. Because of that the cooperation with the northern emirs was more than a necessity.

52 See more details in Falola and Heaton (2008: 112-116).
} 
and third, to force Nigerians to work in this direction. ${ }^{53}$ Both authors conclude the efficiency of indirect rule in the following:

In the period before the 1930 the British colonial regime developed and implemented its program for imperial dominance in Nigeria. Indirect rule became the cheapest, easiest, and most ideologically attractive way to justify the colonial presence. Indirect rule theoretically preserved indigenous political institutions, but the nature of these institutions was significantly altered by the colonial presence (Falola and Heaton 2008: 134).

The transformation of the Nigerian economy and society soon became visible. Indirect rule contributed to that change. Britain benefited from Nigeria and exploited its mineral and human resources. Additionally, the colony became a market for British industrial products. Nigeria on the other hand benefited from imported European goods, and the construction of railways and roads. Prior to the 1930s a Nigerian national identity was not yet constructed: "Prior to the 1930s Nigerians by large did not see themselves as 'Nigerians' at all” (Falola and Heaton 2008: 137). This explains the rise of national movements after that period of time. Better educational facilities in Nigeria and Nigerian intellectuals educated in Europe contributed to the formation of a sort of national consciousness which was deeply rooted in the region (Falola and Heaton 2008: 137-139). ${ }^{54}$ The formation of associations and the intensification of political activism were basic elements for politically oriented organizations. These institutions were the result of personal initiatives of Nigerian activists. That is why Nigerians used to be very regionally and ethnically oriented. The National Council of Nigeria and Cameroon (NCNC) was founded in 1944 in the south-east of the country. In 1943, the Northern People's Congress (NPC) was established in the north. The Action Group (AG) was set up in the southwest region. ${ }^{55}$

We return to our focus on Islam and British policy during the colonial period - the title of Jonathan Reynolds' publication on "indirect rule" in Nigeria summarizes the British policy on Islam in Nigeria up to the 1930s, where Reynolds refers to the British differentiation between "good and bad Muslims" (Reynolds 2001: 601-618). The author points out that the British kept the structure of governance established by Usman dan Fodio in the Sokoto Caliphate intact. Centralization of power and affiliation to the Qaddiriyya were basic elements of the system. The British explicitly declared respect for the Islamic faith and allowed Muslims to continue practicing their religion without disturbance. The experiences in India and Egypt compelled the British admin-

\footnotetext{
53 Falola and Heaton (2008: 119); see also ibid. (116-118) for the amalgamation of Nigeria.

${ }^{54}$ Falola and Heaton mention the increase of primary and secondary schools in Nigeria between 1912 and 1937. In addition to that development, the number of students and Western educated Nigerians increased as well.

55 See Falola and Heaton (2008: 140-154) for more details on political activism and initiation of ethnicand regional-based organizations/parties.
} 
istration to change its strategy and to avoid confrontation with Islam. The colonial administration made efforts to keep its "image" towards Islam and Muslims neutral as Reynolds confirms it (Reynolds 2001: 601). This policy was perceived even by the different Muslim groups in the north as tolerant, and they readily accepted imposed categorizations of "good" and "bad" Muslims according to their affiliation, resistance to the British, and readiness to cooperate (Reynolds 2001: 602-603).

The Qādiriyya Sufi brotherhood, the largest Sufi order in the north, was positively perceived by the colonial authority. The British characterized it as a "peaceful sect," "state-friendly," a "non-fanatical branch of Islam," and "the tarika (Sufi order, RbA) of the region" (Reynolds 2001: 605). Its previously established structures were maintained and integrated in the "indirect rule" guidelines. No doubt that this understanding was good for both the Qādiriyya and the British; the Qādiriyya kept its hegemony over the northern region and the British relied on a strong partner. A good example of the success of this partnership was the appearance of a Mahdist movement in the northwest in 1906. This movement revolted against British presence and rallied people to revolt against Christians and not to cooperate with them. Collaboration between the Sokoto army and the British forces succeeded in putting an end to this upheaval. This served in enhancing the Qàdiriyya image. Furthermore, the order was for the British more or less isolated from external influences since they did not want the whole northern region to be exposed to "Islamic thought" from outside (Reynolds 2001: 606-608).

The Qādiriyya order was seen to represent the "good Muslims" by the British. Other Sufi groups like the Tijāniyya, the Sanūsiyya, and Mahdist oriented Muslims were considered by the British to be among the "bad" ones. Reynolds indicates that the British neither made clear differentiations between Muslim groups nor between their doctrinal differences. Realistically, British colonialists tended to avoid any possible resistance, especially from those groups with ties to other parts of Africa where resistance agaist French colonialism occurred. When Nigerian Muslims passed through other Muslim communities on their pilgrimage to Mecca, they were at risk of exposure to ideas of resistance (Reynolds 2001: 609-611). The Tijāniyya was largely suspected by the British because of its relation to other centres in Africa like Senegal, Algeria, and Morocco. Its exclusiveness means that Tijānīs cannot join another order and cannot pray behind another tariqga-imām. This was a source of suspicion for the British (Reynolds 2001: 613 and 616). Reynolds revisits the strategy behind the British indirect rule and its relationship to the Qādiriyya and Tijāniyya as well to other groups as follows:

... British rulers of northern Nigeria were instead evaluating orders such as the Qadiriyya and Tijaniyya according to a complex set of assumptions about Islam. Chief among these was the association of Islamic education and piety with "fanaticism," but other important issues included the structural relationship of 
each group to the system of Indirect Rule and their spiritual linkages beyond the region of northern Nigeria. (Reynolds 2001: 618)

In addition to this policy of understanding the religious landscape of northern $\mathrm{Ni}$ geria, the British planned on reforming Islamic law and reducing its validity. All judgements which were not compliant with the British law tradition were to be revised and corrected.

\subsubsection{English law or Islamic law}

The juridical aspects of "indirect rule" were implemented in three different proclamations: the first one was the Native Courts Proclamation of 1900 and consisted of the institutionalization of native courts at four different levels (A, B, C, and D). The first level A, headed by the Grand Qadi and the emirs, was able to impose the death penalty (with approval by the High Commissioner). At a later stage, judgements defined by the British as "inhuman" were revealed and abolished. The second proclamation known as the Native Revenue Proclamation of 1906 consisted of implementing a direct taxation, assisting the emirs in fixing the level of taxes and simultaneously giving them the opportunity to keep a considerable part of the revenue to manage their territories. The last proclamation of 1907, called the Native Authority Proclamation, legally recognized local chiefs even outside of the emirs' juridiction. It fixed the duties of district heads, as well as their salaries within the emirates or native authorities. ${ }^{56}$

Islamic law was categorized under "native customary law". The existing Alkalai (Hausa: judges) as well as the Sharia Courts kept their jurisdiction. In addition, English law was implemented. The so-called "residents" controlled the application of Islamic law. Through this measure, Sharia Courts were placed under a British tradition of law. The Emirs protested against such measures insisting that Islamic law should not be revised by the British. The establishment of the Supreme Court signalled the end of all speculations and hopes of Muslims. British law became superior to Islamic law. ${ }^{57}$

The juridical landscape in northern Nigeria in the 1950s and 1960s was characterised by the presence of two different law traditions: British common law and Islamic law based on the Māliki School of law. The classification of the cases according to the four grades (A, B, C, and D) mentioned above allowed for the handling of court cases according to their importance and the competence of the judges (Alkalai). In the late 1950s the so-called Moslem Court of Appeal and Sharia Court of Appeal were instituted to deal with Islamic matters. The general structure was initiated by the British within their indirect rule policy. The British gave the impression that they were not

\footnotetext{
56 See Ikime (1970: 8-12) and Reynolds (1999: 60-61).

57 See Sodiq (1992: 85-108). The author narrates an example of a Christian woman banned from inheritance she supposed to receive from her Muslim father by an Islamic Qadi. The woman appealed the case to the Supreme Court that gave her the right of inheritance. The judgement of the Islamic Court was then invalidated (Sodiq 1992: 97-98).
} 
intervening in Islamic law affairs. In fact, they were interested in increasing the legitimacy and the significance of traditional rulers in the north. The supreme authorities of the judicial system were British Magistrates assigned to deal with cases involving British citizens and appeals from Alkali Courts grade A. ${ }^{58}$

The British attempted to restrict Islamic law to personal, family, and inheritance matters. Criminal law with corporal punishments such as stoning or amputations was not applied. Interestingly, the recognition of Islamic law was strategic. The British recognized Islamic jurisprudence but put it under strict supervision. The important changes of Islamic law in northern Nigeria under the British occupation are summarized by Oba in three stages: "accommodation phase," "domination and control phase," and "the living under the shadow phase." 59 Islamic law was classified as customary law in Nigeria, as was the case in all British colonies. According to Oba, this classification was advantageous for the colonial authority because it "retards the growth" of Islamic law and "allows the British to impose their values and customs" over Muslims, and gives common law judges an opportunity to "adjudicate on Islamic law matters" (2002: 827). Furthermore, this classification restricts Islamic law and avoids any possible conflict with other laws, especially on a religious basis. Being a Muslim was not the only criteria for handling cases of legal conflicts amongst Muslim parties. The identification with Islamic law is decisive to its applicability (Oba 2002: 828). This classification allowed the judges trained in customary law to deal with cases of Islamic law and at the same time allowed Muslims to escape Islamic law (Oba 2002: 829).

According to Abun-Nasr, Islamic law was classified under native law and custom of Muslims until the year 1956, when a Muslim Court of Appeal was established. This means that Islamic law was a matter of Native Courts (proclamation of 1900) whose jurisdiction was limited by a "repugnancy clause" defined by the British authority and allowing them to repeal any judgement (Abun-Nasr 1993b: 204). ${ }^{60}$ The emirs were given the authority to impose punishments like the death penalty after 1906. These kinds of verdicts could only be enforced by the governor of Nigeria. The death verdict could be replaced by imprisonment. The strategy of the British consisted of reducing the Emirs' judgements to ta'zir (in Arabic: discretionary penalty of judge) and avoiding the budūd-punishments (in Arabic: one of the four categories of Islamic penal law, mostly associated with corporal punishment) (Abun-Nasr 1993b: 206) ${ }^{61}$. These expectations were confronted by an internal judicial struggle between the Emirs and Islamic judges. ${ }^{62}$ Chief Alkali Courts and Judicial Councils (under the supervision

\footnotetext{
${ }^{58}$ See Reynolds 1999: 60-63. The author indicates that most cases of appeals from Alkali Courts to British Magistrate were "cases of political nature."

59 See Oba (2002: 825). The author took this classification from Yadudu (1988: 4-5).

${ }^{60}$ The repugnancy clause consists of stopping any judgement of the Native Courts when it does not conform to "natural justice, equity, and good conscience".

${ }^{61}$ For more details on the Islamic criminal law see my M.A.-Dissertation (Ben Amara 2005), in particular, chapter 5 "Die Šarīa-Rechtsprechung".

${ }^{62}$ Abun-Nasr (1993b: 207) mentions a judicial struggle that lasted until 1906 between the Emirs and the Chief Alkali. The Idea of Lugard was to restrict the jurisdiction of the Emirs Court to siyasa
} 
of the Emirs) existed side by side in the north and was categorized under grade $\mathrm{A}$ of Jurisdiction until the judiciary reform of 1933. Abun-Nasr counted 19 Chief Alkali Courts and 22 Judicial Councils that existed at the time. The goal of the British to make homicide cases a duty of Alkalai failed and the colonial authority attempted to change its strategy of improving Alkali Courts over the Emirs' authority (Abun-Nasr 1993b: 207).

The fact that the Alkalai cooperated in many cases with the Emirs more than with the British when it came to homicide decisions confirms that the old judicial structure continued to exist. The new tactics of the colonial authority consisted of translating standard books of Islamic law used by Nigerian Islamic jurists. This approach should have given British officers some knowledge of Islamic law and at the same time the ability to monitor judgements made by Islamic courts. In 1933, the so-called Native Courts Ordinance was established. An English court existed on top of this institution. It was the last court of appeal (High Court, in Kaduna) to which cases from Alkalai Courts and Judicial Councils were directed (Abun-Nasr 1993b: 208-209).

Abun-Nasr observes that the clash between Islamic and English law took place especially when the colonial authorities tried to change the penalty designated for homicide. According to the Māliki School of Law followed in northern Nigeria, the intention in homicide cases is decisive in defining the penalty. If the crime took place with the intention to kill, the penalty is death. If it is not the case, then diya (in Arabic: blood money) could be paid to the victim's family. The British preferred not to apply capital punishment whose applicability was a marker of Islamic law and the identity of the Emirs. The colonial administration avoided declaring the Emirs' decision as invalid and put it in the hands of the governor. The governor was in the position to change the penalty according to the "right of pardon" ("Begnadigungsrecht" - to use AbunNasr's term) or even annul it if they deviated from English law (Abun-Nasr 1993b: 209-210).

The applicability of Islamic law including Islamic criminal law through the Emirs is part of the Muslim identity. The British insisted that, by including Islamic law in customary law, it can be applied to the entire country. Muslims were never happy with such a policy and they called for the establishment of the independent Islamic Courts of Appeal and for the application of Islamic law in all its aspects (Abun-Nasr 1993b: 212). The situation changed before the independence of Nigeria through the partition of the country into three major regions and the drafting of the constitution of 1954. This constitution aimed to establish a Muslim Court of Appeal in the north. At the same time, a Penal Code which was inspired by British India and Sudan was set up, as well a Criminal Procedure Code. Even though this Penal Code retained some aspects of Islamic Criminal Law (such as lashes for adultery or drinking alcohol), it put an end to Islamic law as a whole (Abun-Nasr 1993b: 213). This fundamental change of Islamic law was the result of political compromise and served the interests of northern

(political decisions) and to allow Alkali-Courts to decide over homicide cases. This vision was not easily manageable. 
politicians as well as the British colonial administration. Islamic law was then limited to personal law and the Sharia Court of Appeal replaced the Muslim Court of Appeal. ${ }^{63}$ With the independence of Nigeria in 1960 the debate on Islamic law in the federation took a new direction. How Nigerians deal with Islam and Islamic law and what kinds of debate(s) took place will be discussed in the next chapter. Certainly, Islamic law, which was reduced to personal law by the British, will be a subject of debate not only in the north, but in the entire country.

\subsubsection{Islam in Nigeria during the postcolonial era}

Nigeria's independence and the formation of the modern state in 1960 was a challenge for Muslims, Christians, and adherents of African Traditional Religions. The preparation for independence started several years earlier with the constitution of $1946(R i$ chards Constitution), the constitution of 1952 (McPherson Constitution), and finally the constitution of 1954. Nigeria was divided into three major regions before 1960: north, east, and west. Additionaly, Lagos was declared a federal territory. There were High Courts in these regions and Federal Supreme Courts on the federal level. For the local context, the Native Courts of Appeal as well as the Moslem Court of Appeal existed under supervision of the High Courts. Through this structure, the British colonial administration succeeded in limiting Islamic criminal law and situating it under the British law tradition (Hock 1996: 191). The new Penal Code (mentioned above), which was inspired by the Sudanese judicial system, was ratified in September 1960. Islamic law became more meaningful, especially in civil matters. The so-called Moslem Courts of Appeals were replaced by Sharia Courts of Appeals (Reynolds 1999: 95-96).

Hock describes the new judicial system in Nigeria in the early years of independence as follows: the top of the system consisted of the Supreme Court of Nigeria, followed by the Federal Court of Appeal and Federal High Court. At the level of the provinces there were State Courts represented in all states by the State High Court or by the State Sharia Court of Appeal and in some states by the State Customary Court of Appeal. The last category of the judicial system is represented by the Area Courts and the Customary Courts at the local level. Judicial cases were handled according to this hierarchy from the local to the federal level. The Federal High Court was the place where ultimate judgements were taken. In case of conflict between two different law traditions (for example, a struggle between a Muslim and a Christian), an agreement over one court (Islamic or not) was made (Hock 1996: 192-193).

\footnotetext{
${ }^{63}$ According to Abun-Nasr, Ahmadu Bello who was the Chairman of the ruling party of the north Region (the Northern People's Congress; NPC) was ready to compromise on Islamic Criminal Law. He sent a delegation to Libya, Pakistan and Sudan in 1957 under the premise of comparing their law systems influenced by the British law tradition. In 1958, a committee of law experts was initiated by the government of the north and asked to prepare a report as well as a recommendation for northern Nigeria. After a long debate and political pressure, the Emirs accepted the reform in September 1959. For more details see Abun-Nasr (1993b: 213-216).
} 
According to Ostien and Dekker, the implementation of the Penal Code of 1960 was to the advantage of Muslims in northern Nigeria. Although the new Penal and Criminal Procedure Codes replaced the Native and Customary Criminal Law and became standardized for all Nigerian citizens, and although Sharia Court jurisdiction was reduced to personal matters, the Emirs Courts lost much of their juridical weight to the Provincial Courts. At the same time, the Alkalis' Courts were asked to rely on the Penal Code (translated into Hausa) instead of using Arabic law books. Muslims nevertheless maintained higher legal prestige in the federation (Ostien and Dekker 2010: 564-566). This prestige was achieved through the establishment of the Sharia Court of Appeal whose judgements (usually restricted to Islamic family and personal law) were final and could not be revised by other courts. In addition, the Native Courts Appellate Division was instituted with the duty of listening to cases of Native Courts directed to the High Court. The Native Courts Appellate Division consisted of three judges: two from the High Court and one from the Sharia Court of Appeal. Another advantage for Muslim judges was that they could handle cases according to Islamic law as long the conflicting parties agreed on it and confirmed it in written form (Ostien and Dekker 2010: 567).

The judicial system introduced in Nigeria after independence worked well and judges were in a position to handle Islamic, English, or customary law. Problems started in 1967 when Nigeria was divided into twelve states instead of the existing four regions. Through this partition six new High Courts, six Sharia Courts of Appeal, and later a Court for every state was established. Ostien raises the problem in the following statement: "How to harmonize the work of all these new state courts, while preserving the essential elements of the settlement of 1960?" (Ostien and Dekker 2010: 569). For the High Courts the situation was unproblematic since they could appeal to the Federal Supreme Court. For the Sharia Courts of Appeal, the situation was more complex because judgements from these courts were divergent and could not be directed to any other court. The establishment of a final, Upper or Federal Sharia Court of Appeal was suggested as a solution to the issue. This kind of court's role was to solve cases from the different Sharia Courts and to solve all judicial questions between them (Ostien and Dekker 2010: 569-570). ${ }^{64}$

Throughout the 1970s, the need for establishing a Federal Sharia Court of Appeal became more apparent. Particularly in relation to debates over the new constitution of 1979 and the transition to the Second Republic ${ }^{65}$, shari $^{-} a$ turned out to be an issue in the country. The preparation for the new constitution started in 1976. Two years later, the Constituent Assembly turned down the proposed establishment of a Fed-

${ }^{64}$ For more details, see Ostien (2006: 221-255).

65 The First Republic in Nigeria lasted from 1960 to 1966. In 1966, the Civil War over the secession of Biafra started. A military government took over from 1970. General Murtala Muhammad, the head of State at the time, announced in 1975 a transition to a civilian government. He formed a Constitution Drafting Committee (CDC) with the aim of sketching the new constitution of the federation; see Ostien and Dekker (2010: 570). 
eral Sharia Court of Appeal and suggested that the related section 180(1) c from the planned constitutional draft be removed. As a protest against this decision, Muslim deputies left the assembly. ${ }^{66}$ The then head of the state, General Obasanjo, appealed to all factions to engage in dialogue. The Constituent Assembly proceeded with its task on August29, 1978, and the new constitution was presented on September 1, 1979 without the Federal Sharia Court of Appeal clauses. Apart from that, states could create State Sharia Courts of Appeal in case they elected to establish such courts. ${ }^{67}$

The debate on Islamic law did not stop in the postcolonial period. For many Muslims this law is part of their identity and cannot be replaced by any other law. If Muslims were ready to compromise that Islamic law be reduced to personal and family matters by the British and that Islamic Criminal Law be integrated in the Penal Code of the whole country, they were not ready to compromise when it came to the Sharia Court of Appeal.

The democratization process in Nigeria in the 1980s was interrupted by the military, and the Second Republic came to an end in 1983 when General Buhari became head of State. Two years later general Babangida took over after a successful coup d'état. Babangida announced a transition to a civilian government by end of the 1980 s and a new discussion about the constitution of the federation in the Third Republic of Nigeria arose again. The head of the state set up a political board in 1986 with a consultative function pertaining to the judicial situation of the country. Muslim leaders of the ten northern states requested that Islamic law be extended beyond personal matters. Replacing the expression "personal law" with "Islamic law" in Decree 26 in 1986 of the constitution of 1979 made this expectation feasible. Also, the creation of Sharia Courts of Appeals was allowed (Hock 1996: 196).

The constitution of 1979 was again revised in 1988 and several committees were asked to come up with suggestions. According to Hock, Committee 16 was concerned with the $\operatorname{shari}^{-} a$-issue. From the beginning, views were divided between Muslims asking for obligatory Sharia Courts of Appeal in all states and Christians suggesting removal of all shari'a sections from the constitution. On November 28, 1988, the representative of the military government stated that the absence of any compromise, all negotiations over $\operatorname{shari}^{-} a$ were halted. A few days later an official declaration was announced, keeping the 1979 constitutional formulation (Hock 1996: 197-198).

Hock describes the shari'a discussions in the 1980s as the "second round" of the debates on Islamic law. Several factors hindered the establishment of a law system combining British secular law with traditional Islamic law. Muslims never forgot the devaluation of their law by the British and used any opportunity to revive it. Christians considered $\operatorname{shari~}^{-} a$ a danger and tried every means to have it removed from the constitution. The Military government failed to solve the shari'a-controversy. At the

\footnotetext{
${ }_{66}$ According to Abun-Nasr (1993b: 221), 88 among 93 Muslim deputies left the Assembly. Hock (1996: 194) indicates that all 93 Muslim members protested by boycotting the meeting.

${ }^{67}$ In Section 240 (1) of the 1979-constitution it was indicated that establishing State Sharī' $a$ Courts of Appeal is allowed "for any state that requires it" (see Ostien and Dekker 2010: 572).
} 
same time Nigeria was passing through a political, economic, and social vacuum during the 1980s. The division between Christians and Muslims took on another dimension with the absence of a compromising policy of Babangida's administration. Hock articulates the controversy surrounding Nigeria's membership in the Organisation of Islamic Conference (OIC) in 1986 and the crisis related to it. Hock wonders if such a membership can be explained as a "grand design" or a "misleading step" of the government of Babangida. Certainly, such an event motivated Muslims and Christians to put greater stress place on religion in Nigerian politics. ${ }^{68}$

The 1980s were not different from the crisis of 1979 when it came to the shari ${ }^{-} a-$ issue. Questions related to Islamic law in the constitution were still not answered. The establishment of Sharia Federal Courts failed several times since Muslims and Christians did not find a way to compromise. The democratic election of 1993 with the elected President Abiola gave Nigerians hope that the third transition to civilian government (the Third Republic) could solve the country's problems, including judicial controversy. These hopes disappeared very soon when a new coup d'état occured in the same year and the military took over again until 1999. The era of General Sani Abacha was one of the most unstable periods in Nigerian postcolonial history. The turmoil in all sectors deeply affected the Nigerian experience with democracy. According to the historian Toyin Falola, "... General Abacha ... abolished all the elected national and state assemblies, dismissed all the state executives, dissolved all the local government councils, and banned all political parties" (1999: 195).

General Abdulsalami Abubakar became head of state after Abacha died unexpectedly in 1998. As part of his accession, he promised a speedy transition to democracy. Within a few months new presidential elections were organized and Olesegun Obasanjo was elected President of Nigeria. From 1999, the Fourth Republic was proclaimed and a new controversy over the constitution and Islamic law arose once again.

The civil war, the military regime, the transition to democracy, the constitutional and judicial debates, and the political discussions about Islamic law in Nigeria during the postcolonial era overshadowed other debates within the different religious communities. The ongoing political discussions in the federation seemed to be a confrontation between the two major religious communities: Muslims and Christians. In the following section, the intra-Islamic debates among Muslims in Nigeria, especially the struggle between the Sufi-brotherhoods and subsequently against Sheikh Gumi are evaluated. These debate(s) can be understood as the historical background of the Izala movement formation.

\footnotetext{
68 The OIC is an Islamic organization that was established 1969 in Fez, Morocco. General Babangida registered Nigeria 1986 in that organization apparently for economic reasons. This act raised a big controversy between Muslims and Christians in the federation. The form of the state (secular, Islamic) was especially contested; for an overview on the debate see Hock (1996: 212-235).
} 
Ramzi Ben Amara: The Izala movement in Nigeria

\subsubsection{The conflict between the Sufi brotherhoods}

The Qādiriyya Sufi brotherhood is the oldest and most dominant Sufi order in northern Nigeria. The Sokoto Caliphate played a decisive role in spreading the Qādiriyya. Most leaders of the jibād movement of Usman dan Fodio were members of the Qàdiriyya (Loimeier 1993: 129). The Tijāniyya came to Nigeria in the nineteenth century and soon became a counter-pole tariqa. If the leaders of Sokoto were members of the Qādiriyya, then the Tijāniyya spread among traders and religious scholars. According to Loimeier, the controversy between both brotherhoods dates back to 1845 when a debate arose about the affiliation of Usman dan Fodio's son, Muhammad Bello, to the Tijāniyya. That was the starting point when affiliation to one of these turuq (pl. of tariqa) became religiously and politically meaningful. Being "Qadiri” means the conservation of Dan Fodio's tradition and changing to Tijāniyya means a rebellion against Sokoto rulers and the old tradition. In addition, Kano emerged as a new centre of the Tijāniyya that became increasingly independent from Sokoto, the Qādiriyya centre. At the beginning of the twentieth century, the two brotherhoods started looking for more adherents and prestige in northern Nigeria and building networks with Sufi centres outside of the country, particularly via Kano, where trade and religious contact was intensive (Loimeier 1993: 130-131). The more Kano became economically prosperous and religious affiliation became an important part of social life, the more the growth of the Tijāniyya became visible. The contact with Morocco and Senegal was intensified. Even the Emirs of Kano were affiliated with the Tijāniyya and strove for legitimacy through their membership to the tariqa. ${ }^{69}$

The Tijāniyya changed from being a tariqa of traders and scholars to a mass-movement in Kano and in other parts of northern Nigeria. This can be attributed to the success of Sheikh Ibrahim Niasse ${ }^{70}$ as the Tijāniyya leader of West Africa as well as the affiliation of the Emirs of Kano with this tariqa. The Qàdiriyya reacted to such a development through the actions of Sheikh Nasiru Kabara (1925-1996) who tried to reform his own brotherhood. Apart from building networks with the hometown of the Qādiriyya, Bagdad, Sheikh Kabara initiated a reform project of his tariqa in Nigeria. Among others, he introduced the celebration of the birthday of 'Abd al-Qādir al-Jīlānī in Kano as well as the bandiri-celebrations (Hausa: drum) in the mosques. He also became the Qādiriyya Caliph in West Africa (Loimeier 1993: 134).

The Sufi dispute over hegemony and followers within Muslim Nigeria took on a political dimension during the 1950 s. For political parties, Sufi brotherhoods represented a source of networks and potential voters. The brotherhoods themselves

\footnotetext{
69 Loimeier indicates that the Emir of Kano between 1903 and 1919 'Abbas was a member of the Tijānīyya. Emir Abdullahi Bayero (r. 1926-1954) was initiated into the Tijānīyya by the Senegalese Sheikh Ibrahim Niasse (1900-1975) during a pilgrimage to Mecca in 1937. Also, Muhammad Sanusi, Emir of Kano between 1954 and 1963, took advantage of the contact with the Tijāniyya in order to become more independent from Sokoto; see more details in Loimeier (1993: 131-133).

70 For more details on Sheikh Niasse's life and influence, see Seesemann (2011).
} 
became involved in politics and increased their political influence and the numbers of their followers. Having religious, economic, and political influence was part of the "rules of the game." Nevertheless, the more the political weight of religious leaders increased, the more ambivalent and risky this influence turned out to be (Loimeier 1993: 135). ${ }^{71}$

The politicization of religion in northern Nigeria can be seen through the debate on the identification of many Tijāni youth with the political party, northern Elements Progressive Union (NEPU), and the reaction to that by Ahmadu Bello northern People's Congress (NPC) as well as by other religious leaders. In addition, a religious debate over the correct way to perform prayers (with qabd or with sadl) emerged. ${ }^{72}$ The Tijāniyya leader Sheikh Ibrahim Niasse tended to pray with qabd, while Sheikh Nasiru Kabara preferred $s a d l$. This became a political issue among adherents and a reason to divide mosques as well for blaming kufr (non-belief) on each other during the 1950s and 1960s. The discourse consisted of finding proof for each point of view in the tradition of the Prophet. This controversy was used by Sardauna Ahmadu Bello in his political program. The political leader tended to condemn qabd and distanced himself from both Ibrahim Niasse and the NEPU. This pragmatic choice reflects Bello's interest in avoiding any obstacles blocking his political agenda of "one north." The qabdsadl-controversy came to an end in the mid-1960s. In the following years it became a minor issue particularly with the appearance of Sheikh Gumi as an opponent to Sufis and Sufism. ${ }^{73}$

Reynolds understands the link between the Qādiriyya and NPC as well as between the Tijāniyya and NEPU as a "cooperation ... [that] was constantly being renegotiated as necessitated by changing political conditions" (Reynolds 1999: 179). Historically, the spread of the Tijāniyya in Kano and Zamfara State was a continuation of a long resistance against the center of Qaddiriyya, Sokoto. The Qādiriyya was linked to the authority of the emirs and was positively perceived by the British. In times of violent clashes, sanctions were imposed on the Tijāniyya (Reynolds 1999: 183). ${ }^{74}$ The measures against the Tijāniyya varied from banning the order from building mosques to stopping some of its practices (wazi $i f a^{75}, q a b d$ ) in the public sphere (Reynolds 1999: 184-185).

\footnotetext{
${ }^{71}$ Loimeier speaks of the "political instrumentalization" of religious debates among religious scholars from the 1950s.

${ }_{72}$ Qabd means praying with arms crossed in front of the navel and $s a d l$ means having them alongside the body.

${ }^{73}$ Ahmadu Bello set up the Kaduna Council of Malamai in 1963 in order to solve the issue of qabdsadl. The report recommended that Imāms should practice sadl since it is the common practice of the Maliki School of Law, see Loimeier (1993: 136-138).

${ }^{74}$ Reynolds (1999: 183) also gives an example of the clashes between the Qādiriyya and Tijānīyyafollowers in the 1940s. In Sokoto, the riots in 1949 resulted in many mosques of the Tijāniyya "levelled on the order of the Sultan of Sokoto."

75 The wazịfa is especially practiced by Tijāniyya adherents in Nigeria. It consists of a daily remembering of Allāh through reciting "lā ilāha illa Allāh" (there is not God but Allah) 100 times, 100 times șalāt
} 
The Sufi-orders' involvement in politics does not mean that all Qādiriyya followers are members of the NPC and that all Tijāniyya are members of the NEPU. Reynolds gives examples of Tijāniyya members who were in leading positions of the NPC. There were also leaders of NEPU who were not affiliated with any brotherhood. Ordinary members of political parties are from both the Qādiriyya and Tijāniyya (Reynolds 1999: 187-188). The rivalry between the two parties and two Sufi orders was a feature of the 1950s and 1960s. The situation was complex and boundaries between religion and politics were in many cases blurred. At the beginning of the 1960s the NPC set up a new brotherhood called Usmaniyya as an attempt at reunification of all Sufi Brotherhoods under the umbrella of Dan Fodio's tradition. These efforts failed to attract the attention of Sufi leaders and came to an end with the Sardauna's death. ${ }^{76}$

The rivalry between the Qādiriyya and Tijāniyya was largely due to their struggle for space in northern Nigeria. Both Sufi brotherhoods attempted to attract more followers. Over time, both developed two different indications of identity. The Qàdiriyya was (and is) related to the Sokoto caliphate. This gave it the opportunity to be in the centre of events. The Qàdiriyya was the Sufi order associated with the state. It was then the order of the political elite within the NPC. The Tijāniyya was a symbol of both rebellion against established structures and opposition. The link between Tijāniyya and the NEPU is intelligible. The ideology of the party and its founder (Aminu Kano) was based on criticism of the elites in the north, the authority of the emirs, and the colonial administration. No wonder that NEPU was perceived as a symbol of opposition in the north as was the case with the Tijāniyya. John Paden makes an interesting observation when he compares NEPU to a Sufi brotherhood: "... a network similar to the zāwiya [Sufi corner or place] structure of the reformed brotherhoods was developed. Members of NEPU referred to each other during this period as 'brothers' ('Yan Uwa)" (see Paden 1973: 273-305).

Yasir A. Qadri confirms that the relationship between the Qādiriyya and the Tijāniyya during the period of 1956 and the mid-1960s was violent (Qadri 1981: 373). ${ }^{77}$ Both brotherhoods were concerned with propagating their ideology and attracting more members. Both claimed superiority over the other țariqa. They tended to "convert" new members to the order and at the same time warn adherents about the consequences of leaving their tariqa-path. These ideas were propagated in the form of writings by leaders who expressed their reciprocal criticism. From the Qãdiriyya side, Sheikh Nasiru Kabara in one of his publications criticized the Tijāniyya order and

al-fātiḥ (a special Tijānī prayer), and 100 times of istighfär (seeking forgiveness from Allah).

76 Reynolds (1999: 185-206) summarizes the complexity of affiliation to a Sufi order and at the same time being member of political party (NEPU or NPC) during the 1950s and 1960s. The affiliation to the Qàdiriyya or Tijānīyya was used to achieve political goals. The efforts of the Sardauna to unify the north under one party (NPC) and one Sufi order (Usmaniyya) on the eve of the independence failed.

${ }^{77}$ Qadri narrates violent events between the Tijānīyya and Qādiriyya in Sokoto in the year 1956 (Qadri 1981: 378-380). In the same area, riots between the two groups took place in 1965 leaving eleven victims. These events reflected the high tension between the Qadiris and Tijānīs especially in Sokoto province (Qadri 1981: 280-282). 
warned his followers not to become members of it. The Tijāniyya answer came from Sheikh Abubakar Atik who offended Sheikh Kabara and even doubted Kabara's status as a Sufi (Qadri 1981: 376-377). ${ }^{78}$

In conclusion, the two dominant Sufi brotherhoods in northern Nigeria struggled for authority and power within the religious field. This contestation was based on winning new adherents, strengthening networks to other religious centers in and outside of Nigeria, and opposing each other's ideologies. The Qãdiriyya and Tijāniyya both presented themselves as the most appealing țariqa to Nigerian Muslims. They criticized each other's path, questioned each other's rituals, and doubted the legitimacy of each other's sources. Both orders claimed supremacy and the authenticity of their origin. The Tijāniyya succees in attracting many followers was considered dangerous by the Qãdiriyya. Loimeier formulates it rightfully when he describes the growth of the Tijāniyya in the following: "The Tijāniyya was about to literally remove the ground from under the feet of the Qadiriyya” (Loimeier 1997a: 72). After the formation of political parties from the 1940s the tariqa-controversy took a political dimension. For politicians, taríga including its leaders and followers presented a potential medium through which to reach the masses. For Sufi Brotherhoods, dealing with political parties and being involved in politics was a way to broaden their influence and protect their interest. ${ }^{79}$ With the appearance of Sheikh Gumi as an active member in the religious politics of northern Nigeria, the Sufis had to change their strategy towards fighting a "common enemy" who started attacking Sufism in all its aspects.

\subsubsection{Sheikh Abubakar Gumi and his struggle against Sufism ${ }^{80}$}

The intra-tariqa controversy ended in the mid-1960s. This period of time was characterized by several events in Nigeria. Apart from gaining independence and the introduction of the penal code, the death of the Sardauna and the subsequent civil war in 1966, Nigerian Muslims witnessed the establishment of Jamāat Naṣr al-Islām (in Arabic: Society for Victory of Islam, JNI) in 1962, which was an institution to unify all Muslims irrespective of their social background and religious convictions.

Sheikh Gumi (1922-1992) was not only a religious authority in northern Nigeria during the 1960s, but also a political figure. The Sheikh served as a religious adviser of the Sardauna and accompanied him on several trips to Arabic and Muslim countries. The idea behind setting up the JNI was to unify all Muslims in Nigeria despite their different religious orientations. Sheikh Gumi was at the head of the JNI and received

\footnotetext{
${ }^{78}$ Sheikh Kabara wrote a text titled "al-Nafahāā" in which he attacked the Tijānīyya heavily. Sheikh Atik replied in two books entitled risāla fi tậdhir al-ișābah al-ạ̣madiyya al-tijānīyya (1958) and alsarim al-mashrafi al-maslül ala al-munkir al-ghabi (1959). In both he criticized Sheikh Kabara and at the same time defends the Tijāniyya; see also Paden (1973: 143-144).

${ }^{79}$ For more details on the Qādiriyya-Tijāniyyya conflict as well their involvement in politics see Loimeier (1997a: 71-82).

${ }^{80}$ For details on biography and writings of Sheikh Gumi as well his reform-program and the relationship to Sufi orders see chapter "Reform Islam versus Sufism".
} 
financial assistance for the institution from Saudi Arabia and Kuwait. Sheikh Gumi was fluent in Arabic and knowledgeable in Islamic law and tafsir (in Arabic: exegesis of the Qur'ān). In addition to that, he was privileged to be very close to the Sardauna. This position gave him the opportunity to build networks of contacts in Nigeria and the Islamic world. Sheikh Gumi became the Grand Qadi of the north in 1962, a prestigious post that afforded him influence in Arewa (the north).

The political and religious influence of Sheikh Gumi made him a "supervisor" of Islam and Muslims in Nigeria. From his position, he even criticized the well-established brotherhoods as well as the traditional authority of the emirs or the Sultan. The Sheikh confessed: "I knew I was not in their [the emirs] good books.... I often criticized their deviation from Dan Fodio (sic) path" (Gumi and Tsiga 1992: 108). Sheikh Gumi criticized the position of Sufism in Islam and the way sainthood was propagated and practiced. He even doubted what had been said about Sheikh 'Abd al-Qādir alJìlānī (Qādiriyya) and Aḥmad al-Tijānī (Tijāniyya): "Both Sheikh Abdul Qadir and Sheikh Ahmad al-Tijjānī were innocent of most what was written about them, including many practices which they were said to have advocated or sanctioned" (Gumi and Tsiga 1992: 147). Sheikh Gumi criticized the supernatural power attributed to SufiSheikhs. He opposed considering them as intermediaries who are able to communicate with God. He refused the claim that Sufi sheikhs received special prayers through the Prophet. He denounced the expectation of favors through sacrifices and the use of drums and in mosques. For Sheikh Gumi, Sufis have neither access to the hidden nor are they privileged among other Muslims (Gumi and Tsiga 1992: 138-142).

After the death of Ahmadu Bello in 1966, Sufis reacted to the attacks of Sheikh Gumi and wanted him to leave the JNI: "at times, even the meetings of the Jamāat Nașr al-Islam (JNI) became more an avenue to isolate me and charge me with sowing crisis in the society" - as Sheikh Gumi formulated it (Gumi and Tsiga 1992: 149). Because of his opposition to them he lost the legitimacy and political backing that was present during the lifetime of the Sardauna. In addition, the JNI failed to be an organization for all Muslims of Nigeria in the absence of a compromise between the leaders from the different Muslim groups. During the late 1960s and the beginning of the 1970s, Sheikh Gumi concentrated on his tafsir-sessions as well as his writings (Loimeier 1993: 140-141).

\section{Sheikh A. Gumi: his early life until $1972^{81}$}

One cannot study the postcolonial history of Islam in Nigeria without dealing with Sheikh Abubakar Gumi. ${ }^{82} \mathrm{He}$ was one of the most influential Islamic scholars from the 1960s until his death in 1992. He was present in religious circles, served as Grand

\footnotetext{
81 The choice of 1972 is related to the publication of Gumi's book in which he attacked Sufism. The biography of Gumi himself in this chapter goes beyond 1972.

${ }^{82}$ For the life of Sheikh Gumi I rely on his Autobiography A. Gumi with I. A. Tsiga (1992) and Loimeier (1997a).
} 
Qadi of the northern Region (1962-1967), worked as a pilgrim's officer in Saudi Arabia, and was a member of the Constituent Assembly of the Räbitat al-älam al-islāmi (Muslim World League). ${ }^{83}$ He was also close to Sardauna Ahmadu Bello (1909-1966), Premier of the northern Region, and acted as his religious adviser (for Bello see Paden 1986).

Sheikh Abubakar Mahmud Gumi was born in 1922, in Gumi, in the modern-day Sokoto State. He was educated by his father, Mallam Mahmud na-Gumi. He attended the Central Middle School (1936-1942) in Sokoto and moved to Kano to study Islamic law at the prestigious Sharia Law School. He traveled to Sudan where he studied Arabic and graduated in 1951. Upon his return to Nigeria Sheikh Gumi was appointed as a teacher in Maru, in what is now Zamfara State, before he moved to the School of Arabic Studies in Kano, the same institution he attended several years ago. Gumi was appointed as deputy Grand Qadi of the north in 1960 and three years later, he served as Grand Qadi of the northern Region. In 1976, he was appointed as Pilgrims Board Chairman $^{84}$. General Murtala Muhammad (1938-1976), president of Nigeria (1975-1976), appointed Gumi as Grand Mufti but the coup d'état of 1976 and his assassination hindered this measure (Shehu 2001: 1).

In his autobiography, Sheikh Gumi mentioned that he was a peaceful person who avoided any kind of conflict. He was "blessed with an excellent memory" and he liked mathematics, geography, and history, and had trouble with the English language. At an early age, he started identifying himself with religion: "Identifying me with the religion quite early in life, was, indeed, a moral and social check" (Gumi and Tsiga 1992: 20). He studied the classical work of Islamic law like Mukhtassar, al-Risala - to mention some (Gumi and Tsiga 1992: 23). ${ }^{85}$ At school, Gumi met prominent personalities who later became famous figures of the country. Among others, Gumi was taught by Mallam Junaidu, the later Wazir of Sokoto. Also, the Sardauna, Ahmadu Bello was teaching in the same school in Sokoto. Shehu U. Shagari, who headed Nigeria as President between 1979 and 1983, was a classmate of Gumi in Sokoto and later in Kaduna College (see Gumi and Tsiga 1992: 22-34). During his time in Sokoto, Sheikh Gumi was close to Aminu Kano, one of the prominent activists and oppositionists to the British colony. Both of them, along with Shehu Shagari, were known in Sokoto as trouble- makers: “... the three of us, Malam Aminu, Shagari, and I were marked down as being dangerous to the peace in Sokoto province" (Gumi and Tsiga 1992: 48).

\footnotetext{
${ }^{83}$ For an overview on the Muslim World League see Schulze (1990). In Schulze's book, Sheikh Gumi is mentioned with other prominent Islamic personalities as member of the Constituent Assembly of the IWL in 1964 (Schulze 1990: 227). He is also mentioned as a member of the majlis al-ala al-alami li-lmasajid, MAAM (World High Council of Mosques) in 1975 (Schulze 1990: 285). It is also mentioned that Gumi was a delegate in the Egyptian Organisation majma al-bubüth al-islamiyya (Academy for Islamic Studies) from 1972 (Schulze 1990: 237).

${ }^{84}$ For details on pilgrimage politics in northern Nigeria see Loimeier (1988: 201-14).

85 The Mukbtassar al-Risāla is considered a standard book of Islamic law in Nigeria. It was written by Sīdī Khalīl (d. 1365) on the basis of the al-Risāla, a work by Ibn Abī Zayd al-Qayrawānī (d. 996); on an overview on Maliki law and its application in Nigeria see Ghazali (n.d.).
} 
Ramzi Ben Amara: The Izala movement in Nigeria

After primary school, which Sheikh Gumi finished in three years instead of four, he attended a Middle School in Sokoto, and then he attended a Qadi School in Sokoto between 1942 and $1943 .{ }^{86}$ Later, Sheikh Gumi went to Kano where he joined the School of Arabic Studies ${ }^{87}$ and graduated with the highest distinction in four years (Gumi and Tsiga 1992: 34). After his graduation, he served as Secretary of the Chief Alkali between 1947 and 1948. Being uncomfortable with his job, Sheikh Gumi left Sokoto again to teach in the newly established Teacher Training College in Maru, Katsina. The Sheikh remained at that institution for 18 months. He was unsatisfied, especially regarding the ignorance about religion and basic knowledge of Islam:

I observed quite early that both students and workers in the school were in many respects ignorant about their religion. They had no significant knowledge about the proper Islamic regulations even as they affected their daily life. They did not observe Islamic Etiquette in much of their conduct. Many could not say their prayers well. In fact, some could hardly perform the ablution. (Gumi and Tsiga 1992: 47-48)

In town, Sheikh Gumi observed that people performed tayammun (in Arabic: connotation of ablution with sand if water is not available) and not wudu $\bar{u}^{c}$ (in Arabic: ablution) and even the Imam of the Central Mosque did so. As a result, Gumi started praying with students on the school grounds and warned them about going to the mosque in town (Gumi and Tsiga 1992: 48). At the same time, the Sultan of Sokoto gave a speech during the Muslim 'ĩd celebration ${ }^{88}$ thanking Allāh, the Prophet, Usman Dan Fodio, and the King of Britain. Gumi sent the Sultan a letter warning him about thanking the King of Britain. Disappointed, the Sultan wanted to punish him. Gumi was charged with illegal praying on the school grounds, stopping students from going to Friday prayers, and for pretending to be a mahdi (Gumi and Tsiga 1992: 49-51). ${ }^{89}$

The next step in Gumi's life was his move to Kano where he began to teach in the same School of Arabic Studies that he attended as a student. During this period, Gumi applied for a scholarship to study in Egypt, but the government decided to send him with seven others to the Institute of Education in Khartoum, Sudan. ${ }^{90}$ Sheikh Gumi left Sudan in 1956. In 1957, he became the Pilgrims Welfare Officer in Jeddah, Saudi Arabia. In Mecca, he was confronted by established Sheikhs who guided pilgrims for

\footnotetext{
${ }^{86}$ See Abul-Mumin Sani (1994).

${ }^{87}$ Sani Umar points out that "... the School (School of Arabic Studies, Kano) came to be regarded as the breeding ground of Anti-Sufism in Nigeria" (1988: 169).

${ }_{88} i d$ is the most important religious feast of Muslims. The are two different 'id celebrations: the first one is the first day after the fasting month of Ramadan and the second one occurs during the hajj period and during which all Muslims sacrifice (a sheep/a cow in memory of the Prophet Ibrāhīm's sacrifice story in the Qur'ān).

${ }^{89}$ Being a mabdi seems to have a negative connotation in northern Nigeria during Gumi's time.

${ }^{90}$ Paden (1986: 301) mentions that six students (including A. Gumi) traveled to Sudan for Bakht alRuda School in Khartoum, Sudan.
} 
money, and he tried to change their attitude towards pilgrims (Gumi and Tsiga 1992: 69). According to Loimeier, the fact that Sheikh Gumi was close to "religious scholars of the neo-Wahhābiyya in Saudi Arabia" (Loimeier 1997a: 182) and a leading member of the rābitat al-älam al-islāmi founded in 1962 meant that he was largely identified by Sufis and others in Nigeria as representative of Wahhābiyya in the country.

Back in his country, Sheikh Gumi served as Deputy Grand Kadi for two years (1960-1962) and was promoted to Grand Kadi, when Sheikh Awad, of Sudanese descent and holder of that position, went back to Sudan. Gumi described his years in the Sharia Court of Appeal as "memorable" and he appreciated the work of that body to establish justice in northern Nigeria (Gumi and Tsiga 1992: 96-97). Of course, such a position allowed the Sheikh to come closer to politicians. He became the "principal adviser" of the Sardauna Ahmadu Bello. Both travelled together to several countries in Africa and the Middle East and went on 'umra to Mecca every year during Ramadan (Gumi and Tsiga 1992: 102-104). This opportunity of travelling in the Islamic world and observing Nigerian Muslims especially during their visits to the Holy Land provoked Sheikh Gumi to establish an organisation to educate Nigerians about their Islamic faith. That was the idea behind the JNI (Jamäat Nașr al-Isläm: Society for the Victory of Islam) established in 1962 with financial assistance from Saudi Arabia and Kuwait. ${ }^{11}$

Although Sheikh Gumi held the position of Grand Kadi, he was passionate - as he confessed - about teaching and preaching. The opening of the Sultan Bello Mosque in Kaduna in 1963 gave him a good opportunity to fullfil this passion. His tafsir sessions were attended - apart from ordinary people - by prominent politicians (the Sardauna amongst others). Sheikh Gumi used this opportunity to transmit his message(s): "I was happy with the mosque especially because it allowed me to talk directly to those in authority.... It has always been to my conviction that the best way to effect change in the society is to educate those who have power, about the virtue of justice and the fear of God" (Gumi and Tsiga 1992: 130).

In Kaduna, the Nigerian Broadcasting Corporation started recording the tafsir sessions of the Sheikh in 1967 and transmitting them over the radio. ${ }^{92}$ This happened without special organization or any financial support to the Sheikh. In addition, Gumi started writing in the daily Hausa newspaper Gaskiya ta fi Kwabo in 1970. This access to the media allowed him to propagate his ideas about many religious issues and particularly about Sufism. Gumi dealt with many issues in Islam, from sacrifice to communication with spirits and from attributing a divine nature to Sufi Sheikhs to criticism of drums and songs in mosques (Gumi and Tsiga 1992: 138). Andrea Brigaglia speaks of three phases when it comes to Gumi's tafsirr: the first one was between 1962 and 1966, when Gumi was preaching in Ahmadu Bello Mosque in Kaduna and his audience was "made up of the administrative bourgeoisie of this political centre"

${ }^{91}$ Sheikh Gumi wrote to the Saudi government asking for assistance to set up the JNI. The Saudis donated $£ 100000$; also the government of Kuwait contributed $£$ 300000, see Gumi and Tsiga (1992: 107).

92 See Brigaglia (2007: 173-210). 
Ramzi Ben Amara: The Izala movement in Nigeria

(Brigaglia 2005: 429). During this first period, Gumi "attributed specious elements to Sufism.” The second phase suggested by Brigaglia was between 1967 and 1976, when Gumi's preachings were broadcast for the first time by Radio in Kaduna. Here Gumi avoided open conflict with Sufism and "moderated the anti-Sufi tones of his comments" (Brigaglia 2005: 429). The last phase, which began in 1977, was characterized by "explicit tones" that go as far as takfï (in Arabic: charge of kufr, non-belief). ${ }^{93}$

Sheikh Gumi was a distinguished Islamic scholar. His closeness to the Sardauna Ahmadu Bello opened several doors for him. Gumi travelled to many Islamic countries; He established a network of contacts in and outside of Nigeria, and found access to the media to propagate his ideas and ideology. His criticism towards Sufis and Sufism reached an apogee when the Sheikh published his book al-aqida al-sabìha bi muwāfaqat al-sharī'a, regarded by Loimeier as Gumi's major religious work - apart from his Qur'ān translation into Hausa (Loimeier 1997a: 186).

Sheikh A. Gumi: From al-aqiida al-ṣahịha (1972) to the establishment of the Izala movement (1978)

Abubakar Gumi wrote al-aqìda al-șahīḥa bi-muwäfiqat al-sharīa (The Right Belief Is Based on the shari'a) (1972) in Arabic and gave it first to a Mallam Galadanci, who at that time was a member of the academic staff at the University of Kano, to be revised, and then to a Syrian publisher in Saudi Arabia for publication. Gumi opposed certain doctrines of Sufism in his book, criticized their "access to the hidden" (Arabic: al-bātin), "their communication with the Prophet", and "receiving special prayers from him". Gumi drew upon the writings of Usman Dan Fodio that there is "nothing after the sunna of the Prophet" (Gumi and Tsiga 1992: 142-144). Gumi denounced the idea that a Sufi sheikh can intervene for their disciples during the Last Day (the Day of Resurrection). He criticized the presence of drums in mosques (Sani 1994: 31). He insisted on the idea of the oneness of God (Arabic: tawhid) and confirmed that Muhammad is the seal among all Prophets. Gumi opposed the Sufi idea that the Prophet still exists mystically and continues to transmit instructions (to particular persons, Sheikhs, etc.). Gumi analyzed the issue of sainthood and insisted that "religious obligations" (Arabic: wajibāt) are as important as faith (Arabic: ìmān). $\mathrm{He}$ then discussed the concept of bid'a. He considered bid'a to be all practices that contradict the Qur'ann and the teachings of the Prophet Muhammad. Sheikh Gumi criticized the Tijāniyya Sufi Brotherhood and its practice. Tijānīs believe that șalāt al-fätih (one of their important prayers) was revealed to the founder of the order by the Prophet himself and reciting it is equivalent to six thousand recitations of the Qur'an. Gumi criticized practicing witchcraft and looking for blessings for a particular purpose. $\mathrm{He}$ attacked practicing dhikr and categorized it as bid'a. He also attacked hierarchies in Sufi orders and how leaders are considered as aqtāb (in Arabic: poles) who can receive

\footnotetext{
93 This takfir was especially directed against the Tijānīyya. See Brigaglia (2005: 430).
} 
revelations or communicate with the Prophet. ${ }^{94}$ Gumi's book was not written for the public as he himself confessed: "The book had not been written for general reading, and I was aware that in formulating its major arguments a lot had been taken for granted" (Gumi and Tsiga 1992: 145).

His book was taken up by one of his students, Ismaila Idris, who used it to preach in Kaduna to the public in absence of its author who was by then in Saudi Arabia. This provoked a big controversy and a campaign against Gumi in the media. Sufi brotherhoods defended their doctrines in the media, especially through the writings of their leaders at that time. Both Sani Kafanga and Nasiru Kabara, leaders of the Tijāniyya and the Qàdiriyya, wrote replies to Gumi's books. They used a polemic language to defend Sufism. They blamed Gumi of being a Wabhābi who misunderstood the language of Sufis and their interpretation of the text. The Sufi leaders traced Sufism in the tradition of the Prophet. They claimed to follow orthodoxy and by no means to deviate from it. According to them, Sufism is a part of the sunna..$^{95}$

The situation escalated and reached the grassroots level. Sheikh Gumi was isolated in the JNI (where many Sufi leaders were present), and common people (among Sufis) became agitated against him. The reactions went as far as several attempts to kill him in Kano and Jeddah - as mentioned in his autobiography. The relationship between Gumi and the Sufi Brotherhoods took on another dimension when a new organization called Jamā'at Izālat al-Bid'a wa-Iqāmat al-Sunnah, abbreviated as JIBWIS or simply, Izala movement, was established in Jos 1978. The founder of the organization was the same Ismaila Idris who used Gumi's book to preach in Ahmadu Bello Mosque in Kaduna.

\footnotetext{
${ }^{94}$ Loimeier provides a detailed analysis of al-aqida al-sahīha and the major argument and criticism of Gumi towards Sufi brotherhoods. See Loimeier (1997a: 186-196).

${ }^{5}$ For an overview of the Sufi answers, see also Loimeier (1997a: 197-206).
} 



\section{Reform Islam versus Sufism}

The success of Sheikh Gumi in building a counter-pole to Sufi brotherhoods was limited by the death of the Sardauna. It was necessary for the Sheikh to find other strategies to "survive" politically and religiously. Among others, he heavily criticized General Gowon (1966-1975), head of the military-administration, and accused him of corruption and mismanagement. This reflected the feelings of many unsatisfied young northerners and Sheikh Gumi sympathizers. ${ }^{96}$ Furthermore, broadcasting Sheikh Gumi's tafsir on the radio contributed a lot to his reputation and the transmission of his ideas in northern Nigeria. Sani Umar observes two aspects of the "popularization of anti-Sufism" at that period. On the one hand, the radio presence of Sheikh Gumi as well his publications in the newspaper Gaskiya Ta Fi Kwabo were published in Hausa. On the other hand, Gumi's criticism was shifted from verbal attacks in public discussion to written articles and books (Umar 1993: 163). ${ }^{97}$

\footnotetext{
${ }^{6}$ According to Loimeier (1993: 141) young people under the Muslim Students Society (MSS) were especially attracted by Sheikh Gumi's criticism of General Gowon. They were also unhappy with the military regime of a Christian leader.

${ }^{97}$ In his autobiography, Sheikh Gumi himself confessed that he never visited a radio station or prepared a particular tafsir for the radio. He added that he never earned money for answering questions or for being interviewed by a radio program, see Gumi and Tsiga (1992: 133).
} 
Gumi's ideas and ideology attracted many in northern Nigeria. This can be understood within the context of Nigeria as a whole. The mid-1970s were characterized by another coup d'état which resulted in the appointment of General Murtala Muhammad as head of the state. He was killed only a few months later, and General Obasanjo took over as military president. According to Loimeier, Sheikh Gumi lost his political ambition through these events, especially once the head of the state was a Christian and not a Muslim. ${ }^{98}$

Nigeria reached a certain level of economic stability in the 1970s. This was due to the oil boom at the time. This wealth allowed the country to reconstruct parts of what was destroyed during the civil war. The economic prosperity influenced Nigeria's position internationally. Nigeria attracted not only big international oil-companies but it became another chance for the country to be integrated in the world community. Nigeria joined OPEC in 1971. The country also started playing an important role in Africa while simultaneously ameliorating its relationship with Europe, China, and the Soviet Union. Internally, the economy was based on oil revenues; the currency was stabilized and money reserves were ensured. However, this wealth also had a dark side. Falola formulates it rightfully: "Oil has been a blessing and a curse for Nigeria" (Falola 1999: 138). ${ }^{99}$ Especially during the Gowon-era, several sectors of the economy were neglected. The oil industry did not solve all the problems of the country like unemployment, bureaucracy, bad infrastructure, and mismanagement. The short militaryregime of Murtala Muhammad was promising to fight corruption and to introduce reforms. The civil service sector was particularly affected by these reforms that general Obasanjo continued. Other reforms of government structures were undertaken, particularly at the local level. Internationally, Nigeria succeeded in internationalizing problems of the African continent like the conflicts in Angola and South Africa. Dissatisfaction and government opposition started in 1978, when oil-revenues decreased and the living standards of Nigerians went down (Falola 1999: 151-164). ${ }^{100}$

For the Muslim community in Nigeria, the period between the 1970s and 1980s was characterized by the penetration of a "new trend" - as it is called by Anwar namely, Wahhābism. Anwar explains the rise of these kinds of ideas through both internal and external forces. Internally, the assassination of the Sardauna and the division between Sheikh Gumi and the Sufis destabilized the fragile unity of Muslims. Externally, the socio-economic and political instability as well the connection of Nige-

\footnotetext{
${ }_{98}$ Loimeier (1993: 142) mentions that General Murtala Muhammad appointed Sheikh Gumi as Grand Mufti of Nigeria. This was never realized.

99 Falola (1999: 137-164) describes the economic and socio-political situation in Nigeria during the 1970s and compares the era of General Gowon, General Murtala Muhammad, and of General Obasanjo.

${ }^{100}$ High military expenses and the neglect of other sectors like education, inflation and high taxes as well bad living standards led to protests against the military regime. Falola gives the examples of demonstrations by high school and university students in 1978 (Falola 1999: 158-159).
} 
rian Muslims with the Muslim community as a whole led to the penetration of reform ideas as a proposed solution to the country's problems. ${ }^{101}$

The transition to democracy, the new constitutional draft that started in 1976, and the Muslim call for a Federal Sharia Court of Appeal were important events in that period. The rivalry between Sheikh Gumi and Sufi groups led to his isolation from political participation in the name of the Muslim community. Being a single preacher and ambitious politician against the strong Qādiriyya and Tijāniyya, Sheikh Gumi faced disequilibrium of capacities and power. The formation of a group or organization sharing Gumi's ideology was only a question of time. If Gumi himself was indirect in his criticism of brotherhoods and Sufism, then his student Sheikh Ismaila Idris (1937-2000) was more outspoken and direct in denouncing Sufism. The basis for an anti-Sufi organization was arranged. Unsatisfied young people in a politically, economically and socially unstable state like Nigeria appreciated Gumi's ideas and identified themselves with his writings and statements. The enemies are not only the Qādiriyya and Tijāniyya who deviated from the "right" path of Islam, but also the Nigerian state that failed to find solutions to people's problems.

\subsection{What is reform in "Nigerian" Islam? ${ }^{102}$}

As a way of enhancing the discussion on the issue of reform, this chapter deals with the following questions: Can we speak about reform in African Islam? ${ }^{\text {103 }}$ What does reform mean to Islam? What are the concepts used by African Muslims when they refer to reform? Who can be considered as reformers and who cannot? Are Sufis also reformers or do they oppose reform? Can we consider reformers and Sufis as two opposite poles? Do we need this concept at all? What does "reform movement" mean?104

During my fieldwork in Nigeria and my interviews with Izala followers, Sufis, and other scholars, the terms tajdid (in Arabic: renewal) and mujaddid (in Arabic: renewer) seemed to be widespread among Nigerian Muslims. Interestingly, both Izala and Sufis refer to the same source of tajdid: the Sokoto caliphate and its main figure Sheikh Usman Dan Fodio (1754-1817). ${ }^{105} \mathrm{He}$ is considered to be the first mujaddid of Islam in Nigeria. When I asked about the importance of these concepts and why Muslims need their religion to be renewed, my interviewees drew my attention to one badith of the Prophet mentioned by Abū Dawood (d. 888), one of the most important hadìthcollectors in the Islamic tradition: "At the beginning of every century God will send

\footnotetext{
101 See more details in Anwar (1989: 191-215).

102 Here I mean Islam in Nigeria in all its forms: Sufi-Islam; Reform Islam; and all other Islamic traditions in the West African country.

103 The term "African Islam" is contentious. For an example of the discussions surrounding this issue see Rosander and Westerlund (1997).

${ }^{104}$ For a general discussion of this term see Loimeier (2016).

${ }^{105}$ On the History of Islam and the Sokoto Caliphate as well for the life and influence of Usman Dan Fodio see the introductory chapter on the History of Islam in Nigeria.
} 
Ramzi Ben Amara: The Izala movement in Nigeria

to this community someone who will renew/revive/restore religion." ${ }^{106}$ In theological terms, there has been an on-going discussion concerning the meaning of tajdid. The majority of scholars of Islam link the term tajdid to "explanation," "correction," "revival," and several other meanings.

In Nigeria, many Izala followers consider Sheikh Abubakar Gumi (1922-1992) to be the most important figure of tajdid in the post-colonial era. The fact that he came in the 20th century confirms their understanding that a reformer appears every hundred years. This is interesting because the fourteenth Islamic century commenced in 1882 and ended in 1979. Many theologians accepted the mentioned hadith, but its authenticity is still debated. The literature on reform (tajdid) is linked to diverse definitions and interpretations. In the following, a few approaches will be illustrated.

The historian Mukhtar Umar Bunza tries to look at the impact of the "North African Tajdeed Tradition" 107 on northern Nigeria. According to him, "Tajdeed refers to a periodic renewal of faith. It is thus considered to be rebirth, puritanism, fundamentalism, re-assertion, awakening, reformism, resurgence, renewal, reassurance, revitalization, militancy, activism, integrism, millenianism, messianism, return to Islam, the march of Islam, etc.” (Bunza 2005: 325). ${ }^{108}$ The first experience with reform in northern Nigeria came - according to Mukhtar Bunza - with the Algerian Islamic scholar al-Maghîli $(\mathrm{d} .1505)^{109}$ who came with a religious mission and "advocated the socio-economic transformation and political restructuring of the state to conform to shari 'a" (Bunza 2005: 327). Bunza also considers the distinguished Egyptian scholar al-Suyūṭi (1445-1505), who visited West Africa and then corresponded with Hausa kings, to be one of the contributors to "reform" in that area. He also regards the local 'ulama' during the sixteenth century as a precursors of the reform project in northern Nigeria due to the fact that these scholars brought several writings and books of the Mālikiyya in North Africa (Bunza 2005: 328). ${ }^{110}$ The period between the sixteenth and eighteenth centuries is called by Bunza" period of "emerging scholars," and it re-

\footnotetext{
106 The Book: Sunan Abi Dawood is considered as one of the most important sources of badith collections. In the science of hadith ('ilm al-hadith), many discussions took place on the authenticity of any statement by the Prophet. Without going deeper into those discussions, we have to mention that there are categories developed to classify any hadith. The most known are sabī (in Arabic: authentic), da'if (in Arabic: weak); others use the terms hasan (in Arabic: good) and munkar (in Arabic: rejected), but many other connotations and categorizations exist. More important for one hadith is if it is mutawätir (in Arabic: narrated by several known narrators) or not; considering the quotation from Abū Dawood's collections, a discussion concerning the authenticity of the hadith (mentioned above) if it is authentic or not? There is no clear answer to that question although the majority of Islamic scholars consider it as such.

107 See Bunza (2005: 325-338).

108 Bunza contends that tajdīd started in Nigeria from the fifteenth century, although the relationship between North Africa and Hausaland goes back to the seventh century, the period when Islam reached the north of the African continent.

${ }^{109}$ For the life and influence of al-Maghīlī in Hausaland see Batrān (1973) and H. I. Gwarzo (1972).

110 Al-mudawwana al-kubra, al-risāla al-Qayrawāniyya and mukbtașsar khalīl are some examples mentioned books of Mālikiyya by Bunza.
} 
sulted in the establishment of the Sokoto Caliphate as part of Usman Dan Fodio's reform program during the nineteenth century (Bunza 2005: 330). Bunza mainbtains further that revivalism in the Hausaland seems to have its roots in North Africa's experience with Islamism during the colonial and postcolonial period of the twentieth century. He considers scholars like Hasan al-Bannā’ (1906-1949), Sayyid Quṭb (1906-1966), Muhammed 'Abdūh (1849-1905), al-Afghānī (1838-1897) as "sources of materials and inspiration" for the Nigerian revivalism movement (Bunza 2005: 331). To give examples of reform in post-colonial Nigeria, Bunza mentions Sheikh Abubakar Gumi and the major Islamic organizations that he deeply affected: Jamāat Naşr al-Islām (JNI) and the Izala movement. Also, Zakzaky's "Brothers" movement are seen by him as having been influenced by writers from North Africa such as Sayyid Quṭb and Hasan al-Bannāa (Bunza 2005: 331-333). Bunza goes further in recognizing that the call for shari $a$ in northern Nigeria should also to be understood in the context of tajdìd inspired by Māliki jurisprudence and North African scholars of Islam (Bunza 2005: 333). Thus, Bunza's historical account highlights the distinctive role of the North African scholars in reform in Nigeria.

According to Loimeier (2007), "reform" is linked to several connotations in Islam such as tajdid (in Arabic: renewal); isläh (in Arabic: restitution, restoration); ihy $\bar{a}$ (in Arabic: revival); and saḅwa (in Arabic: awakening). ${ }^{111}$ For Sub-Saharan-Africa, Loimeier identifies the concept tajdid as a key concept for reform during the nineteenth and twentieth centuries. He summarizes his understanding of the concept of reform as "change with a program." Its meaning is especially related - according to Loimeier - to criticism of immoral life or government. Loimeier regards a change during the twentieth century at the level of terminology from using tajdì $d$ to ișlāb which is more related to "programmatic reorientation of Muslim reformers" as well as to "new types of Islamic reform movements in Sub-Saharan Africa." 112 Generally, "reform" is to be found in both academic and non-academic literature and is related to societal, politi$\mathrm{cal}$, and religious movements. The concept is translated as "progress" and "modernization" or as "renewal" of a society on the basis of "fundamental" dogma (Loimeier 2007: 3). Loimeier suggests the following definition of reform: "Reform has many meanings. It has modernizing as well conservative, liberal, progressive, egalitarian, elitist, activist, or revolutionary connotations" (Loimeier 2007: 3). He adds that any reform movement "conduct a specific dialogue with history and the canon of its own religious tradition...." (Loimeier 2007: 4). Loimeier speaks of "markers" that characterize religious reform movements. He lists eleven markers: having particular religious reference (particular person or event), using specific texts and particular interpreta-

\footnotetext{
111 See Loimeier (2007: 2). Loimeier also mentions other concepts that are found in the literature like nabda (renaissance), taraqqī or taqaddum (progress) (Loimeier 2007: 4).

${ }^{112}$ My English translation of Loimeier's German Terminology „programmatische Neuausrichtung muslimischer Reformer“ and „neuer Typus islamischer Reformbewegungen im subsaharanischen Afrika“ (Loimeier 2007: 2).
} 
tion, choosing particular types of organization, and particular position to the state - just to mention some. ${ }^{113}$

Ousmane Kane refers to "reform movements" as "those Islamic movements that attempt to reform social and religious practices" (2003: 7) and differentiates between them and "Islamist movements" that "attempt to capture political power and establish the rule of God" (Kane 2003: 7). Kane's approach links a reform program to social change. This aspect is missing in several studies on Islam in and outside of the African continent. ${ }^{114}$ Furthermore, Kane understands reform - of Izala (the movement he is dealing with) - as a modernity project (Kane 2003: 1-7). ${ }^{115}$

According to Peter Clarke, a sociologist and historian of religion, "Islamic reform in Nigeria is not a new phenomenon" (Clarke 1988: 519). It becomes more visible in the context of the "nation-state" where Muslims as well as Christians were, and still are asked to answer the demands of one nation. From their site, Nigerians (Christians and Muslims) questioned the "character and orientation" of that state (Clarke 1988: 519). Clarke locates Islamic reform in Nigeria in the $19^{\text {th }}$ century. The Sokoto jibād of Usman dan Fodio has not only "religious, political, social, and economic" effects on Muslims and non-Muslims, but it also led to "fear and opposition to Islam which persist to this day" (Clarke 1988: 519). In contemporary Nigeria, Clarke identifies two types of reform: moderate and radical. Clarke makes his differentiation on the basis of the sources used by reformers. He considers those who only rely on the Qur'ān and the sunna of the Prophet as "fundamentalists," while moderates are those relying on other sources (in addition to the two). When it comes to shari' $a$, both (moderate and conservative types of reform) have similar attitudes. Both of them desire to islamize Nigeria although the "fundamentalist" invests more energy in that direction (Clarke 1988: 521-522). Furthermore, Clarke understands "reform" in its social and economic circumstances. By giving the example of Maitatsine riots in Kano in the beginning of the 1980s and the Kafancan disturbances of 1987, Clarke tries to find a link between fundamentalism and Islamic reform. He suggests the following definition:

Fundamentalism is essentially about the reform of Islam for the purpose of creating a more just society along Islamic lines. It is not only a moral response to what it sees as the corrupting influence of western libertarianism and exploitation, and godless socialism, but also a failure of western, secular ... political, economic, and educational systems to provide solutions to the country's problems. (Clarke 1988: 527)

\footnotetext{
113 See these eleven "markers" explained by Loimeier (2007: 4-5).

${ }_{114}$ Ousmane Kane listed several case studies dealing with reform Islam in Algeria, Indonesia, Morocco, Egypt, Oman, Ivory Coast, French Sudan, and Guinea. In these examples, the author misses a "direct causality between social change and the rise of a new Islamic attitudes or beliefs" - as he said. See pp.8-14.

${ }^{115}$ See also Kane's discussion on his understanding of "modernity" in relationship to reform Islam (Izala movement) (Kane 2003: 1-7).
} 
Clarke concludes by making a distinction between what he called "intellectual and moral" reform of the Sokoto Caliphate and between the "purifying" reform that fights innovation and tends to Islamize Nigeria (Clarke 1988: 538).

The expert on Nigerian Islam, Andrea Brigaglia (2004), observes the transformation of the concept of Islamic "reform" in Nigeria. He stresses that the Muslim identity of the elites during the Sokoto Caliphate was related to Sufism and was adopted by the masses. Interestingly, "reform" as a concept is also present in Sufi milieu. Brigaglia gives the example of the "doctrinal reorientation" of the Tijāniyya headed by Sheikh Ibrahim Niasse (d. 1975) ${ }^{116}$ and of the Qãdiriyya led by Sheikh Nasiru Kabara (d. 1996) ${ }^{117}$ in Kano. He also quotes the concepts used by John Paden who speaks of "traditional" and "reformed” brotherhoods (Qādiriyya, Tijāniyya), respectively (Brigaglia 2004: 108-109). The appearance of a "counter-reform" project of Sheikh Gumi (d. 1992) and the Izala movement inspired by him drew attention to a new discussion about reform. The internal discussion among Sufis on reformism seems to have taken a new dimension. This tendency is a result of the anti-colonial resistance of many West African Muslims against colonial masters, but also is due to Islamic education and rapprochement to the Arabic and Islamic world. ${ }^{118}$ Sheikh Gumi is the pioneer of religious reformism in post-colonial Nigeria (from 1969), but it seems that "reform" or "reformism" appear to have been used even during the colonial time. ${ }^{119}$

Sani Umar ${ }^{120}$ uses the concept of "Islamic modernism" to qualify the Izala movement and its Salafi/Wahhābī program. This form of Islam seems to be the counter-pole of the so-called "popular Islam" represented by the Sufis. The argument of Sani Umar is that Izala movement adopted a modern "organizational format" and its leaders and members have such an educational background (Umar 2001: 134). ${ }^{121}$ Dealing with the development of the Izala movement, Sani Umar speaks of the division of Izala movement beginning in 1984 and how doctrinal differences led to different orientations within the movement. On the one hand, a faction of the Izala movement follows the teachings of Sheikh Idris (the founder), which is considered the "hard-liner" faction (fundamentalist); while the other one (those who are largely Medina-educated members) is more moderate or "soft-line" (as Umar calls it). In fact, Sani Umar regards the terms "fundamentalist" and "modernist" as not reflecting "stable realities". He shows

\footnotetext{
116 For more details, see Seesemann (2004) and Brigaglia (2001).

117 See, among others, Loimeier (1997a: 52-70), on the life of Sheikh N. Kabara and the development of the Qādiriyya-Nāṣiriyya.

118 Brigaglia (2004) quotes the study of Lansiné Kaba (1974) on Wahhābism in Mali and how Islamic education in Egypt (Al-Azhar) and Sudan (Omdurman) played a role in the "reformist" movement established in Mali, see Brigaglia (2004: 115-117).

119 In the context of Nationalism and resistance against the British Colony, Sa'du Zungur and Amino Kano criticized the established traditional authority of the 'ulamā' in the north in that they considered it as an obstacle to any "reform" or political progress. See Brigaglia (2004: 116-118).

120 See Sani Umar (2001: 127-150).

${ }^{121}$ Sheikh Gumi and Sheikh Idris attended modern schools like the Kano School of Arabic. Concerning the Sufi-context Sani Umar speaks of a transformation to "virtual civic associations."
} 
the flexibility of both concepts by giving the example of how the " "ulamä"s traditionalism shifts to modernism" and "Izala's shifts from modernism to fundamentalism.". 122

The Africanist and Historian, John Hunwick ${ }^{123}$ observes a "connection" between reform and revival in an Islamic context. Revivalism in Africa started in the $19^{\text {th }}$ century with Usman Dan Fodio in Nigeria and Muhammad Ahmad in the Sudan. Both movements took place to "regenerate" religion (tajdid) and the two leaders appeared to be the $m a b d i^{124}$ (in Arabic: rightly guided restorer of religion) of their time (Kramer 2009: 29-30). Although Nigeria and Sudan have two different experiences with Islam and colonialization, Hunwick links the idea of Islamic revival and Mahdism to social, political, and economical changes in both countries. In Nigeria, Usman Dan Fodio is seen as a mabdi who brought change especially to Muslims. His "movement" became a source of inspiration during the post-colonial era when Muslims called for implementation for shari' $a$ as a solution to the problems of the West African country. In Sudan, the situation is comparable. The rise of change is due to social and political problems of the country. The appearance of the Sudanese mabdī Muhammed Ahmad at the end of $19^{\text {th }}$ century was an answer to colonialism. Islam became an identity marker for Muslims. This revival attempt reflects their wish. Similar developments can also be found in the 1989 implementation of Islamic law - shari' $a$ - as a result of years of social and political instability in Sudan. ${ }^{125}$

The concept of reform narrated above is multifaceted and complex. Sometimes this concept is presented in relationship to new Islamic movements with Salafi// Wahhābī tendencies opposing Sufis and Sufism. ${ }^{126}$ In other contexts, reform is to be found among Sufis - as Brigaglia points out. ${ }^{127}$ In some cases, reform is related to other phenomena (like fundamentalism) and discussed in relationship to it and to the Nigerian nation-state - as Clarke did. ${ }^{128}$ This demonstrates that the concept of reform is fluid and depends on the circumstances in which it is used. I would agree with Kane and Loimeier who relate reform to a "program with change." Analyzing the context of reform instead of defining it appears to be more fruitful. Tariq Ramadan, the popular scholar of Islam, articulates it rightly: "We are in a kind of terminological haze in which the meaning of words is so variable that one no longer knows exactly what the discourse about "reform" refers to." ${ }^{129}$ This sentence summarizes the dilemma of de-

\footnotetext{
122 For Sani Umar's analyses of the two Izala movement factions see Sani Umar (2001: 135-138). Concerning the different types of shifts, see Umar (2001: 138).

123 See Hunwick (2005: 25-42).

124 On the concept of the mabdi, see, among others, Kramer (2009: 448-450). Kramer refers to standard work on the term mabdi and refers to Ibn Khaldun's Muqaddimah, chapter 3 where the term is discussed in sunni as well as shic i Islam.

${ }^{125}$ For more details on revival in Nigeria and Sudan, see Kramer (2009: 32-40).

126 See Loimeier (1997a), Kane (2003) as well as Sani Umar (1983 and 1988).

127 See Brigaglia (2004).

128 See Clarke (1988).

129 See Tariq Ramadan ([2007] 2016); even in the European context, debates on reform are still going on. Ramadan mentions different concepts meaning reform. Among others: Ihy $y \vec{a}$ '(in Arabic: revival),
} 
fining “reform.” In the African context, including Nigeria, we witness similar developments. In times of uncertainty, turmoil, and political instability, the door of "reform" and the need for change are more debated than in times of prosperity. The example given by Hunwick in Nigeria and Sudan shows it very well (see Hunwick 2005).

One cannot study Islamic reform in Nigeria without speaking of the Izala movement. This movement stands for the recent experiences of Nigerian Muslims with a structured organization that took up the course of purifying Islam from innovation and establishing the sunna of the Prophet. Before dealing with "reform" as seen by Izala movement itself, a few other examples of Muslim groups are introduced. Shī'ites, JTI, Maitatsine, Boko Haram or Salafiyya-oriented groups all share one goal: reforming Islam in Nigeria. These groups, their doctrines, and their objectives are introduced in the following section.

\subsection{The Shî́ī movement in Nigeria ${ }^{130}$}

The Shī ${ }^{`} i$ movement was established and led by Sheikh Ibrahim Zakzaky. The genesis of the movement was influenced by the Iranian revolution of 1979 . With time, this influence developed into a full Shī' î orientation. The movement calls itself "The Islamic Movement" and is known in Nigeria as Yan Shi'a (Shî'i people). The group is based in Kano, and it became more visible among Nigerian Muslims as the only group publicly opposing the shari'a re-implementation and declaring this point of view openly.

The Shī'i doctrine originates in Nigeria's social, economic, and political challenges during the colonial era and especially throughout the post-independence period (Sulaiman 1993: 5-9). Inspired by the success of the revolution in Iran and due to Nigeria's turmoil in many directions, Sheikh Ibraheem Zakzaky started introducing Shī' ì ideas to the West African country. Sheikh Zakzaky was born in Zaria in 1950 and studied at Ahmadu Bello University in the same city. He was among the most active members of the Muslim Students Society (MSS) before he left it. He was amongst the students who demonstrated against the state. He visited Iran in the 1980s and came back to recruit new members for his "Islamic movement". He sees in Islam a solution to the country's problems and propagated these ideas through lectures and public gatherings in northern Nigeria. He opposed the nation-state with all its symbols and defined it as a tăgh $\bar{u} t$ (in Arabic: symbol of idolatry, evil). In many cases, demonstrations by Zakzaky's followers turned into violent contestations against the police. Zakzaky himself was imprisoned several times because of his ideas and opposition to the federal state (Sulaiman 1993: 8-10). There were debates in Nigeria during the 1980s and 1990s concerning the "Islamic movement" and whether it was a real Shī'i group or not. The debates were related to the ideology and practices of its members. There

tajdìd (in Arabic: renewal), ișlāb (in Arabic: reform). According to him, tajdìd and ișlāh are more related and complementary. See also his book Radical Reform: Islamic Ethics and Liberation (2009).

${ }^{130}$ For an overview see Sulaiman (1993: 5-16). 
Ramzi Ben Amara: The Izala movement in Nigeria

was no doubt that it started as a political movement inspired by Iran and the revolution of 1979. Nowadays, the movement seems to be fully involved in Shî $\overline{1}^{-} \bar{c}$ doctrine. ${ }^{131}$ Zakzaky's position on the re-implementation and his views in this direction will be elaborated within the context of the shari $a$ debates. ${ }^{132}$

\subsection{The Jamā̄at Tajdīd al-Islām (JTI) in Nigeria}

The Jamācat Tajdīd al-Islām (in Arabic: Society for Renewal of Islam) or simply abbreviated as JTI is an Islamic group that emerged in northern Nigeria during the mid1990s. This group and its main figure Abubakar Mujāhid split from Ibraheem Zakzaky and his Shī ì-project. Sheikh Mujahid himself teaches at Ahmadu Bello University of Zaria. The group seems to have its leading personalities in Zaria, Kaduna, and Kano. I had the chance to visit one of their mosques during my stay in Nigeria. I also interviewed Sheikh Mujāhid himself on the sharīa-issue in Nigeria. As he explained, the group played a crucial role in framing the sharía project. Sheikh Mujāhid was close to Zakzaky and deeply influenced by his ideas. He travelled to Iran after the revolution of 1979. The fact that Zakzaky "converted" to the Shī' ì doctrine resulted in a split from Zakzaky, as well as from some former followers. Ahmad Bello, ${ }^{133}$ a Nigerian scholar from Ahmadu Bello University in Zaria, mentions that a lecture given by Zakzaky on 7 January 1994, led to the split of a group of nine people including Sheikh Mujahid. In this lecture, Zakzaky openly declared the adoption of the Shī î̀ doctrine (Bello 2008: 7-12). Consequently, the JTI declared its own da'wa based on the Qur'ān and within Sunni Islam. It derives its doctrine from Hasan al-Bannä (1906-1948), the founder of the Muslim Brotherhood in Egypt. The slogan of the organization is "Allah is our target, the Prophet is our example, the Qur'ān is our canon, jihäd is our way, and dying for the cause of God is our noble wish" (Bello 2008: 13).

The idea of founding this organization took shape in January 1995. The Muslim Brotherhood of Egypt was used extensively as a model. At the head of the JTI, there is the Majlis al-Shūra al-āmm (in Arabic: General Consultation Board) followed by a Director General. At the third level there is a general secretary, a treasurer, leaders of committees (culture, economy, education, media, first aid, and students work), and a person responsible for the different regions. Under this last category, there are state leaders, then a consultations board at the state level, then group leaders, then halqaresponsibles (in Arabic: circle), and finally family representatives (Bello 2008: 17). Sheikh Mujahid is the Director General and Ustaz Amin is his Deputy. The goals of the JTI can be summarized in six points:

\footnotetext{
131 The Shî̀ î influence is visible on the homepage of the movement https://www.islamicmovement.org especially through celebrations related to Shī̄i Islam. This has been confirmed by a personal visit to AzZakzaky's house in Zaria in January 2007.

132 See the chapter "Sharīa Debate of 1999".

133 See Bello (2008).
} 
a) having an individual Muslim obeying God.

b) creating a Muslim house on the basis of Islamic education.

c) the development of an Islamic society.

d) development of an Islamic State on the basis of the Qur'ān and sunna.

e) making the Islamic revival a reality.

f) the re-establishment of the Islamic Caliphate (Bello 2008: 18).

The JTI stands for an Arabic and Islamic identity and opposes Western cultural colonialism, especially in the field of education. To achieve its goals the JTI has developed Arabic and Islamic educational programs in Bauchi State. It actively supports 'ulamä' who feed into their doctrine, establishes schools dealing with Islamic thought and Arabic language, and preaches in villages (see Bello 2008: 21-29).

In his $\mathrm{PhD}$ dissertation on Islamic civil societies in Nigeria, (Bayero University, Kano), Tahir Haliru Gwarzo (2006) dedicates a chapter to the JTI. He mentions how the movement split from Zakzaky in 1994 and established an independent organization. The author describes the leaders of JTI as "ulam $\bar{a}$ " of solid religious knowledge, devoting their time to teaching, preaching, and advocating the association's ideology" (Gwarzo 2006: 192). Members of the JTI are recruited via public preaching and the activities of the association. Schools and mosques are both good places to recruit newcomers. JTI attracts youth and students. Women's education is also part of the association's concerns (Gwarzo 2006: 193). Being associated with JTI requires registration with an usra (in Arabic: family or cell). Gwarzo categorizes members of JTI into religious leaders, first aid groups/hisba (in Arabic: an Islamic institution for controlling values and enforcing conformity of behaviour according to shari ${ }^{-} a$ ), and ordinary members (Gwarzo 2006: 197). In the matter of resources, the association relies on small donations, wealthy members, school fees, and selling newspapers and business ventures (Gwarzo 2006: 199). The association occupies religious, social, and political fields in northern Nigeria. Its activities vary from seminars and preaching sessions, to public lectures on both national and international issues. Its da'wa activities tend to invite all Muslims without excluding any specific group. The association apparently played a crucial role in mobilizing people for the implementation of Islamic law at the end of the 1990s. Furthermore, it seems that they contributed to the formation of bisba-groups in Zamfara State and to the spread of shari ${ }^{-} a$ in northern Nigerian states (for more details see Gwarzo 2006: 203-279). 


\subsection{From Maitatsine to Boko Haram}

The heterogeneity within the Islamic community in Nigeria is a fact. Scholars face difficulties in giving an exact number of Muslims (and Christians as well) in the country. This is also the case for Islamic groups. For many people, Sufism in Nigeria is only represented by the Tijāniyya and Qādiriyya, but the spectrum of Sufi groups is wider than these two orders (Shādhiliyya and many other Sufi groups are rarely mentioned). Nevertheless, anti-Sufism was basically represented by Sheikh Gumi, and after his death, it was represented by the Izala movement. Among Nigerian Muslims, there are other groups and individuals rejecting Sufism but which are not visible in the society. There are many other groups and orientations mostly within Sunni Islam. The only Shī'i oriented group is that of Zakzaky.

During the postcolonial era and because of the riots in Kano during the early 1980 s, the Maitatsine movement emerged. In this period of time, the struggle between followers of Abubakar Gumi and the representatives of Sufi-brotherhoods reached the highest level of contestation. Maitatsine was a group of Muslims led by Muhammadu Marwa, a religious scholar and preacher-originally from Cameron who settled in northern Nigeria. Maitatsine means in Hausa "may God damn you", and was directed at Marwa's opponents. The movement's leader was related to a revolt in Kano during the 1980s and was killed during one of the riots. The group goes back to the beginning of the 1970s when the number of its followers increased massively. Maitatsine recognizes the Qur'ān as the sole source of Islam. He claimed himself to be a prophet. Apart from his rejection of some Muslim practices, he also opposed Western materialism and all of its aspects. Any kind of dress related to the West was rejected, and even travelling by car or bus was not appreciated by him and his followers. Members of the group were not only Nigerians, but came also from neighboring countries like the Republic of Niger. The Maitatsine was involved in several riots against the police in northern Nigeria between 1980 and 1985. In 1980 in Kano, when the police attempted to arrest Muhammadu Marwa, they were resisted by his followers. The unrest that occurred for a few days resulted in over four thousand victims. The leader himself was fatally injured. The turbulence extended to other parts of the north like Maiduguri, Kano, and continued in Kaduna in 1982, Gongola state (today Adamawa and Taraba states) in 1984, and Gombe in 1985. Many people lost their lives and Nigerian authorities failed even to identify the reasons behind the events. Maitatsine followers were mobile and hardly distinguishable from ordinary people. The majority of the group are poor. This may explain their rejection by the society and their susceptibility to recruitment. ${ }^{134}$ The rise of Maitatsine cannot be studied out of its socio-political

\footnotetext{
134 See Isichei (1987: 194-208). For a historical overview on Maitatsine as well its social, political and especially economical dimension see Lubeck (1985: 369-389). When the Maitatsine riots started the Sufi-Izala movement controversy was going on and Izala movement was accused by the Sufi brotherhoods of being behind the violence. Izala movement then changed its tactics of physical confrontation
} 
and economic context. The same period of time witnessed the rise of other Islamic groups and movements such as Boko Haram. ${ }^{135}$

News on Boko Haram riots in northern Nigeria attracted worldwide attention in the summer of 2009. The brutality and the high number of victims brought the Maitatsine riots of the $1980 \mathrm{~s}$ back to into focus. Mass media reported extensively on the events and were divided in their condemnations of the anti-Western orientation of the movement, on the one hand; while criticizing the Nigerian state's way of dealing with it, on the other. Most German newspapers (like Die Zeit, FAZ, Süddeutsche Zeitung, etc) and magazines (like Der Spiegel, Focus) as well as TV-programs reported extensively on the events at the end of July 2009 and those in December 2010. Also, the BBC and Aljazeera English (to mention other examples) spoke of the riots in $\mathrm{Ni}$ geria. ${ }^{136}$ In the first riots, the media estimated the number of victims to be over 700 . In 2010, several conflicts between Boko Haram and the police especially in Maiduguri were registered and mostly accompanied by deadly shootings. Boko Haram became well known because of its tendency towards Western education and its militant answer to the Nigerian state. There was also an interpretation assuming a connection between that group and the Taliban of Afghanistan. In academia the movement seems to attract the attention of scholars from different disciplines, mostly recently Thurston (2018).

Boko Haram was in fact an Islamic group led by Muhammad Yusuf, a Nigerian Muslim who was arrested and killed during the riots of 2009 in Maiduguri, the capital of Borno state. ${ }^{137}$ The name "Boko Haram" translates in Hausa as "Western education is a sin". The movement is often labeled as a "sect". It is also referred to as the "Taliban of Nigeria" and in many cases people have speculated about its relationship to the Al-Qaeda network. ${ }^{138}$ The group has existed under different names; it had another leader from the mid-1990s (if not earlier) and became visible in Yobe state as a result of its confrontations with the police (Onuoha 2010: 55). ${ }^{139}$ In 2004, some students in

\footnotetext{
from 1981. See more details in Loimeier (1992: 59-80). For the teaching and origin of Maitatsine see also Hiskett (1980: 209-223).

${ }^{135}$ For the rise of Islamic organizations in northern Nigeria from the 1970 s see a description of "the emergence of new Ideas and militant organizations, 1970-1980" by Anwar (1989: 180-269). Among others the rise of Izala movement and Jundullahi (a Sufi oriented and anti-Izala movement organization in Kano) are mentioned as well as the social, political and economic circumstances of Nigeria.

${ }^{136}$ For a comparative study of Aljazeera English and the BBC see Gerhard (2010).

${ }^{137}$ Not much has been written in academia on Boko Haram, but the group is gradually subject of intensive study by researchers from different backgrounds, see e.g. Adesoji (2010: 95-108), Brigaglia (2012a, 2012b) or Loimeier (2012) and recently Thurston (2018).

${ }_{138}$ Muhammad Yusuf (1970-2009) was from Yobe State. He was married to four wives and father of twelve children. He was educated in Chad and Niger Republic. He attended Qur'ānic school and broke with education at the secondary level. He rejected Darwinism, the Nigerian State; and Western civilization. His group sees establishing Sharīa in the whole country is a duty to be fulfilled. See Onuoha (2010: 56-57).

139 Onuoha narrates that the group was known as "Ahlulsunna wa'l-jama'a wa'l-hijra" and its leader was Abubakar Lawan. After that period, it had different names like "Taliban," Yusufiyya, and Boko Haram.
} 
Borno and Yobe withdrew from the university and joined Boko Haram. The Nigerian federal government became aware of the group in 2007 (Onuoha 2010: 55-56).

The group's ideology consists of denying Western culture and way of life, and establishing Islamic values and norms on the basis of the sharía. It opposes the secular state and attempts to resists it. The leader himself made use of Western technology like "exotic cars, the latest communication equipment and the best medical services" (Adesoji 2010: 100). The members of the groups come from different social backgrounds, and vary, from former students and university lecturers to jobless and lawless people. The majority come from an underprivileged background. Many factors have led them to join the movement of Muhammad Yusuf. Among others, lack of opportunities, poverty, educational deficiency, unemployment and corruption (Adesoji 2010: 100). Harbom and Wallensteen see the riots related to Boko Haram as the first “... intra-state governmental power since $1966 .{ }^{140}$ An armed struggle that had already started in 2005 broke out again in 2009 Jonathan Hill relates the rise of Boko Haram to the re-implementation of shari'a in northern Nigeria. According to him, the group emerged in 2002 as an answer to the re-implementation project and quickly recruited adherents among young people, women, and students (See Hill 2010: 1-65).

There are speculations as to where to place Boko Haram within the Islamic spectrum. In the absence of evidence about a link to foreign Islamic movements and organizations, it is difficult to place it within a particular Islamic ideology or group. Nevertheless, it is compared to the Taliban and its model. Apart from that, it is situated within the spectrum of groups with Islamic-Jihadist and fundamentalist orientations. ${ }^{141}$ There is no proof about monetary support from outside to Muhammad Yusuf. Some wealthy sympathizers from northern Nigeria seem to have supported him financially. One can only speculate about the reasons for this assistance. ${ }^{142}$

It was called "Taliban" through the events of December 2003, when the group stormed police stations and other buildings, occupied them and hoisted the Taliban's flag. In 2004, the group founded a base called "Afghanistan" in Yobe state. The new leader was Muhammad Yusuf.

${ }^{140}$ See Harbom and Wallensteen (2010: 501f.).

141 Adesoji mentions that the "modus operandi" of Boko Haram is "fashioned after the Taliban" model. The author also listed the Salafist Group for Preaching and Combat (GSPC) of Algeria, Tablighi of Pakistan, Wahabiyya of Saudi Arabia, and al-Q⿱āi ida as possible links to Boko Haram. These all are speculations of the press in and outside of Nigeria and need further investigation. See Adesoji (2010: 101).

${ }_{142}$ Adesoji speaks of Alhaji Buji Foi, the former commissioner of Borno State, as a supporter of Muhammed Yusuf. There are speculations about other religious leaders and businessmen who believed in Yusuf's cause and may have assisted him financially. The failure of the "Sharīa project" and the desire to make change could be an explanation of that. See Adesoji (2010: 101-102). 


\subsection{Salafiyya ${ }^{143}$ oriented groups}

The Salafiyya is oriented after al-salaf al-săliḥ (in Arabic: pious predecessors; first three generations after the death of the Prophet). There are Salafiyya-oriented groups in the country like the Izala movement, but many Salafiyya scholars act as individuals. The late Sheikh Ja'far clarified in an interview that the Salafiyya as an organized group does not exist in Nigeria. ${ }^{144}$ Salafī ideas are considered to be among the fastest growing Islamic orientations, especially in West Africa (Bala and Umar 2001: 141). Furthermore, these ideas are preferred by several Muslims in this region of the continent: "There is a current fervour among Muslim communities for the $\operatorname{shari}^{-} a$, and the return to the Salaf's vision ranks high in popularity with many Muslim masses in different parts of West Africa” (Bala and Umar 2001: 144). The emergence of Salafiyya ideas in Nigeria can be understood within the context of the struggle against "colonization" and "decolonization" and the rise of Islamic activism after the success of the Iranian Revolution. Salafī ideas were appreciated by educated as well as non-educated Muslims. Mosques, education (especially women's education), and media such as cassettes/VHS-cassettes contributed to the propagation of the Salafiyya (Bala and Umar 2001: 145-147). Its central strategy is to remind Muslims of the onesness of God (Arabic: tawhid) and reject all practices related to shirk. Salafists question the relevance of Sufism and its basis in Islam (Bala and Umar 2001: 148-149).

Sani Umar elucidates that the emergence of Salafiyya in Nigeria took place during the 1960s. According to him, this movement is a response to Sufism. This response became more structured under the Izala organization. Furthermore, the Izala movement is perceived by Umar as a Salafiyya-/Wahhābiyya-oriented organization with a modernist agenda (Umar 2001: 132-134). For Loimeier, the Salafiyya in Nigeria is related to Sheikh Abubakar Gumi, and his tafsir sessions and "dogmatic" contest with Sufi leaders. Sheikh Gumi was inspired by writings of Salafiyya forefathers like Muhammed 'Abdūh, Rashīd Rị̣ā, Sayyid Quṭb, amongst others (Loimeier 1997a: 177). His interpretation of the Qur'ān is to be understood within that same tradition and goes beyond the tradition of the four Islamic schools of law (Mālikiyya, Hanbaliyya, Hanafiyya, Shāfī iyya). Gumi's terminology is strongly influenced by the language used by Salafiyya leaders themselves (Loimeier 1997a: 181).

There are many Islamic groups in Nigeria which follow Salafī ideology. They have different names such as Abl al-Sunna - among many others. They are currently modeled on Islamic centres like Egypt, Saudi Arabia, or Sudan. It is difficult to speak of one organized group or movement called Salafiyya. It is a "trend," or an Islamic orientation within the Muslim community. According to Bala and Umar, this tendency is espe-

\footnotetext{
${ }^{143}$ For an overview on the Salafiyya generally as well for a biography of its leaders see Murtaza 2005. See also the chapter "Izala movement and Wahhābism" for a summary on Salafiyya.

144 Interview in Kano, 2 January 2007.
} 
cially observed among youth (both men and women) and became a kind of "way of life," particularly in places like university campuses (Bala and Umar 2001: 143).

The establishment of the Izala as an organization in Jos in 1978 was an answer and a concretization of many anti-Sufi oriented Muslims. With the foundation of the Izala movement, the conflict with the Sufis turned out to be more equally weighted. The new organization undertook the duty of criticizing Sufism and purifying Islam in Nigeria from all "non-Islamic additions." How was the Izala movement established? Who were its leaders/actors? What was the agenda introduced by the organization? To what extent has Izala movement succeeded in achieving its objective(s)? How did the conflict with the Sufis change over the years? What is the difference between the Izala movement of the late 1970s and the Izala movement of today? All these questions as well as the Izala understanding of bid'a, the relationship between Izala movement and Wahhābism, and division of the organization will be the focus of the next chapter. 


\section{The Izala movement between success and failure}

After dealing with the keyword "reform" itself, the discussion proceeds to some biographical sketches of the life and work of Sheikh Abubakar Gumi, the pioneer of Islamic reform in postcolonial Nigeria, and his student Sheikh Ismaila Idris, who took over from him and established the Izala organization and proceeded with his own "reform" program. Furthermore, the Izala movement is to be described from its establishment until now with a focus on its division, attempts at reconciliation, and its main figures in Nigeria today. Of course, the relationship with Sufis and the doctrinal discourses will not be ignored.

\subsection{Sheikh Ismaila Idris and the Izala question}

The person of Abubakar Gumi overshadowed Sheikh Ismaila Idris, the real founder of the Izala movement in Jos. Even now, some Nigerians (Muslims as well as non-Muslims) still believe that Gumi is the one who set up the Izala movement. This chapter tries to give an overview of the life, influence, and writings of Sheikh Idris, his relationship to Sheikh Gumi and then clarify the Izala question.

Muhammad N. Gurama (2000) described Sheikh Idris as someone who grew up without "games and sport," without "fun and festivity," but who was more inter- 
ested in books since an early age (Gurama 2000: 49). Sheikh Idris was born in 1937 in Gwaskwarom, which is modern-day Bauchi State. His grandfather, belonging to the Jabun tribe (Fulani), came from what is now Kano State with his entire family and their belongings to settle in that area. Sheikh Idris' father, Idris Zakariyya, was an Islamic scholar, an imam, and a preacher in his community. The first education of Sheikh Idris was with his father. Apart from recitation of the Qur'an and the reading of classical books of figh, they looked after their cattle - as is the case for many Fulani (Muhammed 2001: 4). ${ }^{145}$

Muhammed S. Muhammed tried to give an overview of Sheikh Idris's life. He indicated that Sheikh Idris started learning under several Islamic scholars. He was taught Islamic theology, jurisprudence, and Arabic. Mallam Mahmud in Bauchi especially drew the attention of Sheikh Idris to the notion of tawhid. With him, Sheikh Idris read Mukhtasar, among many other Islamic books of the Mäliki School of Law (Muhammed 2001: 6-7). Sheikh Idris then attended the School of Arabic in Kano, where he studied Arabic under Gumi and Sheikh Hassan Khalil who were known for their "anti-țariqa ideas" - as mentioned by Loimeier (Loimeier 1997a: 211). After his graduation, Sheikh Idris was appointed as a teacher in Bauchi State. "He was not satisfied with that because his aim in life was to preach and teach about Islam" (Muhammed 2001: 8). As a result, he left Bauchi to go to Kaduna where he was appointed as a teacher in the Sultan Bello Primary School, which was under the control of the newly founded organization, J.N.I.

His dream of preaching to people was realized in Kaduna, where Sheikh Idris started talking to people after Friday prayers in different mosques (Kawo Mosque, Doka Mosque), particularly in the Sultan Bello Mosque and occasionally in the barracks of the Army. Annoyed by a report of the J.N.I. about how some soldiers turned the Kakuri mosque into a "beer parlour", Sheikh Idris decided to join the Nigerian Army as an imam, and his application was successful (Muhammed 2001: 9-11). ${ }^{146}$ Sheikh Idris was employed in fact as a Chief Imam Grade I civilian in $1^{\text {st }}$ Division in Kaduna. He soon became known by his superiors for his "harsh" preaching, and they tried to send him subsequently to the primary schools to teach soldiers' children, a duty with which Sheikh Idris was not comfortable. At the same time, the Sheikh was also preaching to people in town, outside the barracks. Consequently, he was punished and transferred to Ibadan, where Muslims are few in number. Apart from leading prayers, Sheikh Idris had the duty of solving problems between Muslim soldiers. In Ibadan, Sheikh Idris observed that soldiers had to pay zakatt (in Arabic: alms) from their own salaries to the officers, so he issued a fatwa (in Arabic: legal opinion) condemning that act. ${ }^{147}$ The issuance of this fatwa influenced the relationship between Sheikh Idris and his superiors in Ibadan. Since his first day in Ibadan, and due to his open criticism of the Imam for

\footnotetext{
${ }_{145}$ Loimeier (1997a: 211) indicates that, in addition to Fulani, Sheikh Idris spoke Hausa, Arabic and English.

${ }^{146}$ See also Aliyu (n.d.: 17). Aliyu confirmed the event leading Sheikh Idris to join the Nigerian Army.

${ }^{147}$ See The JIBWIS Journal (2005: 8 and 12). See also Loimeier (1997a: 211).
} 
performing additional practices and recitations after the $z u b r$ obligatory prayer (after midday prayer), Sheikh Idris appeared to many people as a "trouble-maker." Sheikh Idris called the attention of the imam and the congregation that there is no proof of their practice neither in the Qur'ann nor in the sunna of the Prophet. Furthermore, he invited them to read the book of Usman Dan Fodio $i b y \bar{a}$ al-sunna (in Arabic: revivalism of the sunna) (Muhammed 2001: 13-14). After only three months, he was transferred to Kontagora, which is in present-day Niger State.

Sheikh Idris continued his preaching to soldiers in Kontagora, and even people from town came to listen to him and record his sermons/lessons. He then examined the need for establishing a Friday mosque in the barracks and obtained permission from his Captain for it. The mosque attracted many people from inside and outside the barracks and caused problems with the local authorities (Muhammed 2001: 1617). A dispute between Sheikh Idris and an imām from the town - a Sufi - occurred. The situation escalated and finally Sheikh Idris was demoted to Warrant Officer I. Later, Sheikh Gumi intervened as mediator and organized a meeting between his former student and other local scholars in Kontagora. After the meeting, the same imām, who was also the Emir of Kontagora, left his Sufi order ${ }^{148}$ Loimeier regards this event as a political and religious success of Sheikh Idris in Kontagora.

The next important step in Sheikh Idris' life was his transfer to Jos, the capital of Plateau State. Jos is especially meaningful because of its ethnic and religious diversity. The city still holds symbolic relevance for many Izala members today. Not only was the Izala movement as an organization born in Jos, but it also succeeded in a milieu where Christianity has had a long tradition. ${ }^{149}$ Sheikh Idris was sent to the $3^{\text {rd }}$ armored division in Jos, where he was under the supervision of Major Alhassan who was warned about the activities and troubles created by the "new-comer" in the last stations he passed through. First of all, a commitment was made that the Sheikh should not preach in places where a mosque does not exist. Sheikh Idris was in the Rukuda barracks when he started preaching in his residence. After that, he extended his activities to other areas in Jos, especially in the private houses of those who were attracted by the preaching of Sheikh Idris (the house of Alhaji Lawal Mai Suga, and the house of Alhaji Garba Pasali) (Muhammed 2001: 18-19). The preaching activities were also extended to other areas of the town - Dogon Dutse for example-. He attracted more people especially among the Tijānīs, the dominant Sufi brotherhood in Jos. As in other places, there was an attempt to transfer Sheikh Idris to Borno State, but it failed (Loimeier 1997a: 213). The Sheikh was successful in establishing a network of followers. The fact that Sheikh Idris' preaching attracted many followers was the basis for establishing an organized body. It is not clear if Sheikh Idris resigned from the

\footnotetext{
148 See Loimeier (1997a). Loimeier himself relies here on Umar (1983: 51).

149 I spoke to many Izala movement people in Jos who stressed the success of Sheikh Idris in Jos, where many tariq a-people, Christians and Pagans were and are present.
} 
Nigerian Army or if he was dismissed, ${ }^{150}$ but it is a fact that he left his job to form the Izala-organization in 1978. Before dealing with the Izala movement, the crucial events in the life of Sheikh Idris will be summarized, and a reconstruction of his character and personality will be attempted.

Loimeier observed that "recurrent manifestations of protest and rebellion ... seem to have a constant feature in the life and career" of Sheikh Idris (Loimeier 1997a: 212). This is confirmed by the fact that he had several confrontations wherever he worked and lived. He was opposed to many wabala (in Hausa: problems) in and outside of the army barracks. He was under the supervision of the Nigerian Security Service. He was not only interrogated on many occasions, but also jailed in Kano in 1978 (Loimeier 1997a: 214). Sheikh Idris was outspoken and more open to criticizing Sufis and Sufism - unlike his master and teacher Sheikh A. Gumi. In an interview with a former member of Izala movement and actual murshid of the JNI in Jos, Mallam A. Lawal Adam phrased it in the following:

With the coming of Sheikh Ismaila Idris things changed. Sheikh Idris was a student of Sheikh Abubakar Gumi, but he [I. Idris] was more inclined to say: "this is haram (in Arabic: forbidden) and this is against the sunna, anyone who does that is a kaffir (in Arabic: unbeliever). This is the way in which Sheikh Ismaila Idris came across, not like Sheikh Abubakar Gumi who was indirect. ${ }^{151}$

The former Qur'ān reciter under Sheikh Idris, Sheikh Alhassan Said al-Hafiz (in the Kanuri language ala ramma is a title for a person who memorizes the Qur'ān) who accompanied him for several years, also stressed that he (Sheikh Idris) was a strong and severe person. He indicated that Sheikh Idris's character led some Izala-followers at a later stage to doubt his leadership and way of directing the organization. ${ }^{152}$

When we compare both Sheikh Gumi and Sheikh Idris, it can be stated that the latter was more present at the local level. His preaching and confrontations with locally established religious authorities and his superiors in the Nigerian Army made him famous. Followers recorded his preaching and circulated it to other interested people. For Gumi, he was more present in a wider context. His preaching was transmitted in the media and his closeness to the political authority (Ahmadu Bello) as well as his position as a Grand Kadi helped him to expand his doctrine. One common thing between the two was that they preached in the same Ahmadu Bello Mosque in Kaduna, a mosque that holds symbolic meaning for many Muslims in northern Nigeria. Both had the same attitude towards Sufis but they are distinguishable in their methods of criticism.

\footnotetext{
150 Loimeier (1997a: 214), mentioned that Sheikh Idris was dismissed from the Nigerian Army on 7 April 1978. According to Muhammed (2001: 22-23), Sheikh Idris decided to resign voluntarily in order to found the JIBWIS and to concentrate on preaching.

${ }^{151}$ Interview with Mallam A. Lawal Adam in Jos, 27 December 2006.

${ }^{152}$ Interview with Sheikh Alhassan Said in Jos, 12 December 2006.
} 
There is no doubt, that Gumi's influence inspired Sheikh Idris to continue with his preaching against Sufism and Sufi practices. It also assisted him in attracting more followers and escaping direct confrontation with both well-established Sufi brotherhoods and the state. Many Muslims and even non-Muslims today identify the Izala movement with Sheikh Gumi and vice versa. One cannot deny Gumi's impact on the formation, assistance, and support of the organization. The role of Sheikh Idris, the architect of the Izala movement, was crucial. The organization started with Gumi's support and established itself independently from him. In the following section, I will describe the circumstances of the establishment and clarify the role of Sheikh Gumi.

\subsection{JIBWIS: The formation of the Izala movement in 1978}

When Sani Umar interviewed Sheikh Idris, the later told him that the idea of establishing the organization goes back to the time when the Sheikh was preaching to soldiers in the Dogon Dutse neighbourhood of Jos. Civilians were attracted by his preaching through recorded cassettes, and they also came to attend his lectures. At the next stage, Sheikh Idris was invited to preach outside the barracks in "private residences". Many of these people distanced themselves from their brotherhoods to join Sheikh Idris (Umar 1983: 33). At that time, one could observe that the Muslim community in Jos was divided into three major groups: those who joined or were attracted by the teachings of Sheikh Idris; those who were tariqa members; and, finally, the group of neutral people who did not belong to any of these religious groups. ${ }^{153}$

Many observers argue that the establishment of the organization was a way to protect Sheikh Gumi. The fact that he opposed the Sufi brotherhoods as a single person - the same was true for Sheikh Idris - made the establishment of an organization that was an anti-pole to the turuq more than a necessity. In a wider framework, "many politically interested Muslims sought alternative ways to express their political energies and thus engaged themselves in religious organizations" (Loimeier 1997a: 214).

Although Sheikh Gumi described the establishment of the Izala movement as a "quite historic event" - as people reported to him - he couldn't hide his awareness of the new movement and its inexperienced leaders and members:

I was somewhat worried that most members of the new association were young men and women, who combined their learning with a lot of vigor and enthusiasm. My fear was that they might not be very patient in their preaching, especially with older scholars in the society, many of whom had been brought up in a centuries-old țarīqa tradition. (Gumi and Tsiga 1992: 155)

\footnotetext{
153 Interview conducted on 28 February 2007 with Mallam Sani Modibbo, who was an Izala movement follower and held several posts between 1979 and 1987 before he resigned. He also was a $\mathrm{PhD}$ candidate and lecturer in Islamic Studies at the University of Jos.
} 
The organization was launched in Jos on 8 February 1978. Sheikh Gumi was invited but could not attend. He selected two people to attend on his behalf: Muhammad Awwal Abubakar and Ibrahim Arab. ${ }^{154}$ As part of the preparations for the establishment, a committee of seven people was set up. Among others, the committee included Sheikh Ismaila Idris, Alhaji Ibrahim Musalla, Alhaji Musa Muhammad, Alhaji Husseini, Alhaji Sabo, and Mallam Tanimu Aliu. The first concern of the committee was to give a name to the organization. Alhaji Musalla suggested "Jamāât al-Birr wa'l-Taqwā" (in Arabic: Society for Welfare and Fear of God), butthe name was rejected. Sheikh Musa Muhammed suggested "Jamā'at Izālat al-Bid'a" (in Arabic: Society for the Removal of Innovation). ${ }^{155} \mathrm{~A}$ comment came from Sheikh Gumi who was informed of the suggestions concerning the name. According to him, if the organization wanted to fight bid'a, what should be established? Sheikh Gumi proposed "Jamā'at Izālat al-Bid'a wa-Iqāmat al-Sunna" (in Arabic: Society for Removal of Un-Islamic Innovation and Re-establishment of the Sunna of the Prophet). ${ }^{156}$

The inauguration of the Izala movement happened on 12 March 1978. However, the official registration took place much later in 1985. It was on 1 December 1985 that the Nigerian ministry of Internal Affairs signed the certificate of incorporation allowing the Izala movement to be officially registered as an organization. According to my interviewee Mallam Sani Modibbo, every organization must have a formal approval from the Ministry of Internal Affairs. Every organization should also advertise its establishment (in a newspaper). The Ministry gave some time for reactions if there were any objections against the organization. As could be expected, "not hundreds but thousands of objections from all over the country" 157 were sent to the ministry to stop the registration. This "mass-protest" was the reason why the approval of the Izala movement happened in the mid-1980s and it had to do with the fact that Saidu Badawa, then a permanent secretary in the Ministry of Internal Affairs, was an Izala patron and supporter, a factor that facilitated the official accreditation of the organization. ${ }^{158}$ Before being registered, the Izala movement operated under the umbrella of the JNI and had several names like Jamiyyar Yada Addinin Musulanci (Hausa: Society for the

${ }^{154}$ Interview on 5 December 2006 with Ustaz Nasir Abdelmuhyi, Director of High Islamic School, Sarkin Mangu, Jos. Headquarter of the Izala movement A group which is more attached to the founder Sheikh I. Idris.

155 Interview with Alhaji Ibrahim Musalla on 24 December 2006, at his house in the Angwan Rogo area, Jos.

156 Interview on 8 January 2007 with Alhaji Mustafa Imām, National Director of the Izala movement Kaduna First Aid Group, at his house in Zaria. This information was confirmed by Mallam Sani Modibbo during the Interview with him on 28 February 2007 in his office in Jos.

157 Mallam Sani Modibbo Interview, on 28 February 2007 in Jos.

158 Ibid.; Gurama (2000) provides a copy of the "Public Notice" of $11^{\text {th }} / 12 / 1985$ : "This is to notify the general public that the association Jama'atul Izala movementtzul Bid'a Wa Ikamatis Sunnab has applied to the Ministry of Internal Affairs for Registration and the Lan (Perpetual Succession), Act, Cap 98, Law as of Nigeria." It is also mentioned "Any objection of the registration should be forwarded in writing to the Permanent Secretary of the Land (Perpetual Succession) Division, Federal Ministry of Internal Affairs, Ikoyi, Lagos within 21 days of this publication (See Gurama 2000: 157). 
Propagation of Islam) in Kaduna, and Kungiyar Raya Addin Musulanci (in Hausa: Association for the Promotion of Islamic Religion) in Gusau. ${ }^{159}$

The launching of the Izala movement was the result of the efforts of Sheikh Ismaila Idris and several other people around him. Loimeier identifies a crucial role of Sheikh Gumi in "building the organizational structure" of the Izala movement. Furthermore, he argues that many Izala leaders "were former students and followers of Gumi" and they benefited from the "existing JNI networks" in several areas of the north (Loimeier 1997a: 214-215). Furthermore, Loimeier explains the Izala Foundation as a kind of break with the existing traditional networks that dominated not only the JNI, but also the "political establishment" (Loimeier 1997a: 208). ${ }^{160}$ In addition, Loimeier illustrates how the continuation of the struggle between Sheikh Gumi (and his supporters) and the Sufi in Kaduna inspired the "establishment of an organization ... for any effective opposition to the Sufi brotherhoods" (Loimeier 1997a: 210).

Yandaki elucidates the emergence of the Izala movement as a protest against "socio-cultural and economic milieu" on the one hand, and against "ignorant followers of Izala movement" and the jubhal (in Arabic: ignorants) of Hausa society," on the other (Yandaki 1990: 136). Yandaki - as a historian - recognizes three different phases of the development of the Izala movement: the formative period (1978-1982), a period of consolidation (1983-1988), and "Izala as a reality." He adds a fourth and final phase that he calls a "critical phase" (for more details see Yandaki 1990: 116-193). Yandaki tries to understand the Izala movement in the context of its time and relates it to several social, religious, and political events of the late 1970s. He stresses the presence of laborers and students in the movement as crucial elements in the emergence of the movement in both towns and villages. According to him, students are to be found everywhere and at different levels, while laborers are "all over." The Izala protest was against three major social groups: the 'ulamä' who abandoned Islam and followed "mystification and innovations," the majority of the Muslims who followed their sheikhs blindly (Arabic: taqlìd asmāa), and the group of traditional rulers (like Emirs) who kept practices that were non-Islamic (Yandaki 1990: 146-148).

Yandaki considers the first years of the Izala establishment to be the years of "struggle for survival” and of establishing adherents and followers among Muslims. The movement succeeded in recruiting preachers and followers who joined Sheikh Idris in his da'wa. In 1978, the Sheikh wrote a polemical treatise in Hausa entitled Gane bambanci gaskiya da karya (in Hausa: Towards the difference between truth and lies) in which he criticizes Sufism and shirk (Loimeier 1997a: 214 and Umar 1983: 47). Such booklets - especially those written in Hausa, the dominant vernacular in northern Nigeria - are not only read by intellectuals but also by ordinary Muslims.

\footnotetext{
159 Yandaki (1990: 48) lists more names of the Izala movement in different places in Nigeria: Association for Extinguishing Excesses and Establishing the Sunna or Movement of Extinguishing Innovations and Establishing the Sunna (Anka district, Zamfara State), The Association of the Upholding of Islam (Katsina). Umar (1983: 31) uses the name "The Movement of Orthodoxy against Heterodoxy". 160 Loimeier relies here on Umar (1988: 191) in explaining the fact that the JNI "was no longer an adequate platform for his (Gumi's) own efforts of tajdīd".
} 
At the initial stage, when the Izala movement operated under the umbrella of JNI and not as an organized organization or as an independent body, their scholars used Sheikh Idris as an example and followed his path to preach in different places. Gradually, they recognized the necessity of an independent organization that supports the ideology of its founders and protects him and their followers. This is how the idea of the establishment started. ${ }^{161}$ In fact, it is not possible to speak of the Izala movement as an established body in the first years after its establishment. Concerning its program, it was restricted to leading people to the Qur'ān and sunna as basic elements of Islam and to rejecting affiliations with Sufi brotherhoods. Loimeier summarizes the programme of the Izala movement in three points: (a) one can join the Izala movement only if s/he abandons his/her tariqa; (b) the Izala movement is not sectarian; and (c) it recognizes the Nigerian constitution (Loimeier 1997a: 229).

Since Islam in Nigeria was spread on the basis of a long Sufi tradition, especially of the Qàdiriyya and the Tijāniyya, it was necessary for the Izala movement to look for a strategy to deal with the Sufi dominance. Preaching in Jos and other towns and villages was not enough for the Izala movement. Loimeier points out that one of the basic strategies of the movement was to "bring as many mosques as possible under their control" (Loimeier 1997a: 216). This strategy succeeded to a considerable extent; many Sufis were sometimes inclined not to attend ceremonies or festivities because of the "fear" of the Izala movement (Loimeier 1997a: 218). The Izala movement simply "invaded" mosques, took them under its control, and started preaching to people.

The situation escalated violently during the late 1970s between the Izala movement and its opponents. Loimeier sees this development as "symptomatic" of that period, since it was characterized by social and political turmoil. ${ }^{162}$ When the Izala movement gained the attention of many Muslims in the north and received huge support from youth, intellectuals, businessmen, and, of course, the assistance of Sheikh Gumi, the movement started to organize itself internally. In 1980, the so-called Maitatsine riots (see Isichei 1987: 194-208). took place in Kano and influenced the first organizational stage of the Izala movement. The Sufis used the opportunity to blame the Izala movement for violence and cooperation with the Maitatsine (Loimeier 1997a: 218). Many Izala were arrested and imprisoned. This was a turning point for the movement. As a result, they were obliged to change their strategy to a more peaceful program -especially since the Maitatsine riots strongly influenced the development of the Izala movement.

Concerning the Izala formation, Brigaglia speaks of an organization established by Gumi as the first organization of the masses "di tipo modern," with a statute and constitution and concentration on "learning" (Brigaglia 2004: 226). This type of organization, which adapted modern structures, was a new phenomenon among Nigerian

\footnotetext{
${ }^{161}$ Interview with Mallam Sani Modibbo, 28 February 2007.

162 See the chronology of the clashes between Izala movement and Sufis given by Loimeier (1997a: 347-9). Loimeier suggests approaching the history of these events with caution and understanding them in their general social and political context.
} 
Muslims familiar with the traditional way of religious organizations. Sheikh Gumi played a central role regarding the establishment of the Izala organization. This is due to his religious and political influence on Nigerian Muslims from the 1960s. He was not only the Grand Kadi of the north, but he was also present through his writings against Sufis, and his name became familiar to people through the media because of his close relationship to the Sardauna Ahmadu Bello. Sheikh Idris and his supporters eventually took the initiative to establish an official organization. They were divided into preachers and wealthy men who supported the organization with money. Sani Umar differentiates here by calling Sheikh Idris the "principal architect" of the Izala movement and Sheikh Gumi one of the "influential supporters." 163

Through interviews that I conducted with different Izala members, it is difficult to give a precise list of those who attended the founding meetings. It always depends on the perspective of the interviewee. Alhaji Ibrahim Musalla, who is now associated with the Kaduna faction of the Izala movement and whom I interviewed in Jos in December 2006, mentioned that the need to establish an organization was more than necessary, especially to gain more recognition by the state. It also gives the people joining the Izala movement a kind of "identity" when the organization has a name and an address.

\subsubsection{One constitution and two factions}

The Izala movement struggled for many years to gain authenticity and legitimacy among its followers and from the state. It has acquired a constitution detailing its organization, leadership, and structure. After the division of the movement into two branches in Jos and Kaduna, each group considered itself to be the genuine movement. One of the major issues was the constitution of the Izala movement as a registered organization. If a faction decides to draft a new constitution, and declares its independence from the other group, then it should also change its name. Neither group was ready to do so. Changing the name indicates loss of power and damages the image among Muslims. Furthermore, it confirms superiority of one group or the other among the followers. This was the situation at an early stage of the division. After that, a new orientation emerged and there were attempts to amend the constitution according to the new needs of each group. For my analysis, I will be using the following documents: the constitution of the Izala movement as a united organization, ${ }^{164}$ and the amendment ratified by the faction in Jos in 2004 and the Kaduna faction in 1995. This new devel-

\footnotetext{
163 Umar mentions among others that Muhammad Abba Aji Maiduguri (Borno State), Mallam Sidi Attahiru (Sokoto State), Malam Tudu Shikaji and Malam Muhammad Ba'are (Kaduna State) were in the category of those who were close to Sheikh Idris and served as preachers. Others like Sheikh Gumi, Alhaji Musa Mai Gandu, Alhaji Shehu Tabacco were among the "influential supporters". There were also other government functionaries and politicians who also supported Izala movement at its initial stage (see Umar 1983: 48).

${ }^{164}$ A copy of the constitution from the headquarters (1981) which is also to be found in Loimeier (1997a: appendix 4, 351-366); translated from Hausa by Jibril H. Yola.
} 
opment shows that the "two" Izala groups redefined their objectives and continued to be a modern organization by fixing these goals in the constitution. Interestingly, both amendments cite Jos as the permanent headquarters of the movement.

The constitution of the Izala movement (Kaduna faction) is written in Arabic and is dated $3^{\text {rd }} / 08 / 1995$. It bears the signatures of Sheikh Yusuf Sambo, leader of the High Council of Da'wa wa'l-Irshād (in Arabic: propagation and guidance); Alhaji Musa Mai Gandu, the General Chairman of the organization; Ustaz Umar Hassan Imam, Secretary of the High Council of Da'wa wa'l-Irshäd; and, lastly, Muhammad Inua, General Secretary of the Izala movement. The document has fourteen pages with a cover containing the full name of the organization, its headquarters (Jos), and its physical address. The title is Nizamm al-Da'wa al-Salafiyya (in Arabic: Code of the Salaf $\bar{i}$ mission) of the JIBWIS in Nigeria. The slogan of the organization is also indicated: al-Tasfiya wa'l-Tarbiya (in Arabic: clearance and education). Apart from an introduction and a conclusion, the document is organized in four sections, including eight paragraphs. In the introduction, the condition of Muslims in Nigeria is described in the following way:

... some Muslims today are under polytheism, following their passion, under Sufi Brotherhoods, and several myths, some are totally devoted to colonial rule and to plots of communists and others have contributed to the weakness and separation of Muslims today ... ${ }^{165}$

Based on these circumstances, the Izala movement was established in order to invite Muslims to come back to their religion on the path of "al--salaf al-salih". The organization invites Muslims to al-aqìda al-sahiba (rightful faith) and considers the Qur'ān and the sunna to be principal sources for unifying Muslims. What is not included in these two sources is a view on whether the concept of ijtibad (in Arabic: effort, individual reasoning) can be considered "true" or "false" (Izala movement Kaduna Draft of Constitution, 1995: 2).

The first part of the document is comprised of five paragraphs dealing with the establishment of the organization, its name, headquarters, slogan, and a general overview of the organization. In the first paragraph the formation of the Izala movement is described. Interestingly, only Sheikh Gumi and his famous book al-aqida as-sabiha are mentioned. The Sheikh started in Kaduna before a group of 'ulam $\vec{a}$ ' continued to establish the Izala movement in Jos in the year 1978. There is not a single indication to the role of Sheikh Idris and his efforts to establish the Izala movement. This was an attempt to discredit him as the founding father of the organization and eliminate his name from the history of the movement. Even in the next two paragraphs (name, headquarters), only the contribution to the name of the Izala movement by Sheikh

165 Izala movement Kaduna Draft of Constitution, 1995: 1 (my translation). I am thankful to Sheikh Ali Mustapha, leader of the Ulama Council, Maiduguri, Borno State (Izala movement Kaduna) for providing me with a copy of this constitution. 
Gumi (he added/suggested "wa Iqāmat al-sunna") is indicated. In addition, the capital of Plateau State, Jos, is named as the headquarters of the Izala movement.

Paragraph four defines the slogan of the Izala movement as "al-tașfiya wa-l-tarbiya" without giving details. The last paragraph $(\$ 5)$ consists of four points and gives an overview of the organization: first, the situation of Muslims is described. The Izala movement was established to bring Muslims back to the sunna and free them from jahl al-aqida al-islämiyya (in Arabic: ignorance of Islamic faith). Second, the text stresses that the Izala movement is not a political organization acting secretly. It is rather described as an organization of da'wa along the lines of Abl al-Sunna wa'l-Jamäa. When it comes to Islamic sharīa (Arabic: siyāsat al-sharī'a al-islämiyya), the Izala movement is regarded to be part of it. Third, the Izala movement is characterized as a movement that tries to avoid any ethnic, sectarian, or provincial differences. It works for the oneness of God (tawhid) both in- and outside of Nigeria. Fourth, the Izala movement is characterized as a movement that does not rely on a particular madhhab (in Arabic: school of Law), group of people, or person. The difference is based on taqwā (in Arabic: Fear of God) (Izala movement Kaduna Draft of Constitution, 1995: 2-5). The second part of the constitution $(\$ 6)$ deals with the objectives of the organization. These objectives are summarized in ten points:

1. To return to the Qur'ān and the sunna following al-salaf al-șalih in faith, worshipping, human transactions, and in all fields of life.

2. To show Muslims their religion and inviting them to follow its rules.

3. To warn Muslims against polytheism, innovation, (and) new ideas of atheists and communists.

4. To unify Muslims under the same faith and same path in order to establish an umma organized under one flag and one Imam.

5. To purify the Islamic society from polytheism, innovations, myths, etc. in order to create a comfortable atmosphere in which to educate generations of Muslims.

6. To establish "the good Muslim" who is far from polytheism, fundamentalism, and belief in myths.

7. To free the Muslim world from its enemies who destroyed the unity of Muslims.

8. To warn Muslims against sectarianism.

9. Al-tasfiya wal-tarbiya (literally: "cleansing and education").

10. To attempt to set up an Islamic society and practice the rule of God on earth (Izala movement, Kaduna Draft of Constitution, 1995: 6-7). 
This is the path of the Izala movement in Nigeria. The organization invites people in and outside the country to assist in propagating the message of Islam. In order to achieve these goals, the following means are proposed in the third part of the document (\$6). These means are, among others: establishing Qur'ānic schools, establishing an institute for preachers, creating an Islamic cultural center, organizing educational workshops in the entire country, founding a school for Muslim women, assisting orphans and weak people, assisting newly converted, and giving scholarships to needy people (Izala movement Kaduna Draft of Constitution, 1995: 8).

The fourth and last part $(\S 8)$ of the Constitution elucidates the administrative structure of the organization:

- The organization has a General President and two deputies. He is responsible for leading and organizing meetings and for representing the Izala movement.

- The General Committee of Organization is comprised of seventy members representing local governments. The committee elects members of the advisory committee and executive committee of the organization. This committee is headed by the leader of the organization or by one of his deputies.

- The Department of Da'wa or Advisory Committee had twenty-five members and is headed by the leader of al-Majlis al-alà li-Shu'un al-Da'wa wa-Irshäd wa-Talim (in Arabic: High Council of Da'wa Affairs, Orientation, and Education), a secretary, and his deputy. This department deals with da'wa, schools and mosques, fatwās, and teaching. The committees of Education, of fatwās, of Mosques are headed by Administrative leaders within this department.

- The Executive Committee consists of fifteen members, and its meetings are headed by the General Leader of the Izala movement or his deputy (head of the al-Majlis al-alà li-Shu'ün al-Da'wa wa-Irshäd wa-Talìm). In this part, qualifications of $d \bar{a}^{c} \bar{\imath}$ (in Arabic: a person practicing da'wa) are fixed. Every member of the Izala movement is considered to be dáciya. He should be well-versed in the teachings of Islam. His work should be to please Allah and not because of mașlaba (in Arabic: personal benefit). He should be far from any political practice. Any political activity should take place outside of the organization and not in the name of the Izala movement. Everybody should strive to follow sunna personally and in his family, and should be an example for others. He should protect the organization from any defamation.

- The "First Aid Groups" train members who assist sick and injured people. They also organize places of gathering and meetings. They have a uniform similar to the armed forces. 
- The Secretariat is responsible for letters, prints, and everything needed by the organization. This body is headed by a General Secretary who has a deputy.

- The Information Section presents the activities of the organization through publications, loudspeaker, records, and cassettes.

- The Communication Section is responsible for communication within local governments and Islamic organizations in- and outside the country. It represents the organization in any location within the Islamic world.

- The Organization Section organizes meetings and workshops of Izala movement. It fixes the date of meetings. It collects $d a^{c} w a$ requirements and directs preachers to their places of $d a w a$. This body is made of eleven Members (the president and his deputy, the secretary and his deputy, three from the Council of 'ulama', the leader of Information Section, two representatives from the First Aid groups and a representative from the Finances Committee.

- The Finances Section collects money and plans the budget of the organization and organizes the management of resources. It cannot act without the treasurer of the organization, the leader of the Izala movement, and the leader of the Council of 'ulamä'. A seal is necessary for all documents and no transaction can be achieved orally. This section can also initiate projects for the organization to fulfill its objectives (Izala movement Kaduna Draft of Constitution, 1995: 9-13).

The second document is entitled "The Constitution of the Jamatu Izalatil Bid'ah Wa'Ikamatis Sunna." 166 It has twelve pages (the first and last ones are stamped indicating name and headquarters in Jos) and is divided into two major parts. The first part deals with the name, objectives, and membership in Izala movement. The second part concerns sponsorship and structure of the organization. The first few pages give the name of the Izala movement and its meaning: Sheikh Ismaila Idris (written in capital letters) is introduced as the founder, Chairman of the Preachers Council and the "Grand Mufti." Again, this is a marker of the Izala movement in Jos to identify the organization with Sheikh Idris and Sheikh Idris with the Izala movement. Also in this first part of the text, the headquarters is indicated to be in Jos, with offices in the entire country. Concerning membership, it is open to every Sunni Muslim who "protects the dignity of the Organization and Sovereignty of the Nation." The aims and objectives of the Izala movement are specified in the following words: "The organization is purely Islamic and relies only on the Qur'ān and sunna. It is neither political nor

166 I am thankful to Kadi Muhammad Adam Farinkasa for providing me with a copy of this constitution; he ensured that the copy dates from the year 2004. The document itself has no indication of day or year of the amendment. 
tribal. It works to unify Muslims and teach them about the true teachings of Islam” (The Constitution of the Jama'tu Izalatil Bid'ah Wa'Ikamatis Sunna [2004]: 1-3). It alerts Muslims regarding "confusing books" written on Islam and it confirms that the message of the Prophet Muhammad is the last one and opposes any new prophecy. The organization makes efforts to set up education and health in Nigeria in respect of law. It organizes teachings and preaching and makes use of media. It assists the state to keep peace. These objectives are to be achieved in accordance with the Qur'ān and the sunna.

The second part of the constitution begins with an indication of the monetary sources of the Izala movement. The organization relies - as mentioned - on voluntary donations, publishing (books, journals, etc), and farming ( $\$ 4)$. Also, a bank account and a regulation about important documents of the organization are indicated (\$5). The Izala movement holds different meetings at different levels. They can be quarterly or organized when it is necessary. All meetings of the Council of 'ulamä, the Administration or First Aid Groups can only be held in Jos, the headquarters. Any meetings of one of these councils take place when the Chairman, secretaries, and nine members are present (The Constitution of the Jama'tu Izalatil Bid'ah Wa'Ikamatis Sunna [2004]: $4-5)$.

The constitution fixes the structure of the organization (three councils/basic bodies), the composition and function of each council ( $\$ 7$ to 11 ):

The "National Council of Preachers" consists of a Chairman and his Deputy, a Secretary, an Assistant Secretary, a Chairman of the State Council of Preachers, the secretaries to the State Council of Preachers as well as ten preachers and reciters of the Qur'ān. This council is considered to be the highest authority and policy maker for the organization. It organizes policy with administration, appoints or removes trustees, solves problems within the organization, and trains preachers. It has the highest authority as indicated in the following: "The common SEAL of the organization shall only be used or affixed on the authority of a special resolution duly passed by the $\mathrm{Na}$ tional Council of Preachers."

The "National Administrative Council" is considered to be the executive council. It is comprised of a Chairman (and he is also the Chairman of the National Council of Preachers), a Deputy Chairman, a National Secretary, all registered Trustees, the National Director of the "First Aid Groups", all State Chairmen of Administration and Preachers' Councils, all National Officers of the Organization; Secretaries of the Administration Council and Preachers' Council as well as ten representatives appointed by the Chairman of the Council of Preachers and the Deputy Chairman of Administration. The function of this body is to execute decisions of the organization, approve proposals and reports of Committees, approve the budget of the organization, and secure the organization's assets. It can only act under supervision of the National Council of preachers.

The "National Directorate of First Aid Groups" is the third important body fixed in the Izala constitution. It consists of a National Director, a National Advisor, all 
National Officers of First Aid Groups, all State Directors of First Aid Groups, all State Secretaries of Aid Groups, all State Organizing Secretaries of First Aid Groups and all State Discipline Officers of First Aid Groups. This body of the Izala movement also under the Council of Preachers in matters of rules or regulations. First-Aiders have a brown uniform and badge with two cross-swords and a palm tree in the center. They wear blue berets and white belts. This body is allowed to establish new units (The Constitution of the Jama'tu Izalatil Bid'ah Wa'Ikamatis Sunna [2004]: 5-8).

Apart from the three mentioned councils, the Izala movement has Committees that can be set up when necessary, namely, the "education committee," the "committee for finances and general purpose," the committee for health, the committee for personnel and discipline as well as the committee of elders. Depending on the field of action, these committees assist with improving the policy of the Izala movement. Concerning the committee of elders, it serves an advisory function for the purpose of directing the organization properly (The Constitution of the Jama'tu Izalatil Bid'ah Wa'Ikamatis Sunna [2004]: 8-10). The constitution states that the organization should have trustees (between five and seven) who hold this position for the rest of their life. They are under the "Council of Preachers" and are members of the "Council of Administration” ( $\$ 14)$.

The authoritarian character of the organization becomes clear under "General Matters" $(\$ 17)$. This paragraph gives more influence to 'ulama $\bar{a}$ ' in the organization. It can be interpreted as both an answer to the split group and a protection of the Izala leader. These appear in paragraph 17 (b): "The Chairman of the National Council of Preachers shall NOT be suspended or otherwise be removed except if he commits any indecent or criminal offences...” Also, paragraph 17 (d) allows the National Headquarters of the Organization to appoint or remove the Deputy Chairman of Administration and the Chairman of the State Council of Preachers (The Constitution of the Jama'tu Izalatil Bid'ah Wa'Ikamatis Sunna [2004]: 10-12).

The two versions provided by the headquarters (1981) and the translation of the constitution from Hausa are different in some respects from the amendments of Jos and the Kaduna faction. While the constitution of 1995 proposed by Kaduna recognizes Sheikh Gumi as the founder and initiator of the organization and completely ignores Sheikh Ismaila Idris, the Izala Jos version of 2004 dignifies Sheikh Idris as the founder, leader of the Council of 'ulamä', and the Grand Mufti of the Izala movement. This is not surprising even to non-Izala, since the division movement happened at the level of leadership. The objectives and aims of the organization seem to be similar in all versions. This is a confirmation that the split in the Izala movement did not occur at the level of doctrine and objective. The new amendment of the constitution is more about prestige and protection of personalities of the movement. This is visible when it comes to the institutional structure. For both factions, Jos was and is the headquarters of the movement. For the Jos faction, the important change in the new version is the position of the leader and the Council of 'ulama $\vec{a}$. Both are given more power and action in the organization and have the right to appoint or remove any person in the 
organization. The Council of Preachers supervises the other two councils in all directions and has the highest authority when it comes to decisions and policy-making.

For the Kaduna faction of Izala, the new version of the constitution recognizes a general president of the organization. This person represents the organization and chairs meetings. The most important body for this group is the so-called al-lajna al-amma li-tanzim (in Arabic: the General Committee of the Organization). This Committee has the exclusive right to change the other two: the advisory and executive ones. It designs the major structures of the organization and elects the members of the other two committees. This is a hint from the Kaduna faction that the 'ulamä' are part of the organization, but not the most important one. It is an answer to Sheikh Idris that the Administration played and still plays a crucial role in the organization. This council has seventy members, which is larger than the two others (twenty-five for the Preachers Council and fifteen for the Executive Council). Maybe it is a message that the organization should be more "democratic," rather than being under the authority of a single person or a small group of people. Until April 2008, I was not able to get confirmation as to which version was officially approved. From the point of view of the state, recognizing one faction's constitution amendment means denying the existence of the other one. This risky decision can influence the stability not only within the Izala movement, but also the entire Muslim community.

\subsubsection{The structure of the organization ${ }^{167}$}

The Izala organization developed a threefold structure since the early years of its establishment. Even after the division into two major branches, the organization kept its three-dimensional setting. The three bodies of the Izala movement are called councils: The first is the council of 'ulamä'; the second is the council of administration, and the third is the "First Aid Group" (FAG). The three councils are related to each other and are in place to satisfy the needs of the organization. Preachers and other servants of the organization needed an administrative setting that facilitated the work of the Izala movement (authorization to preach; registration of events, official letters, salary management, etc.). These two bodies are complemented by the "First Aid Groups" work.

\footnotetext{
167 This chapter is based on material collected from the Izala movement branch in Jos. I am grateful to Sheikh Sani Yahya Jingir for providing me with some of the organization's publications as well as some of his writings; the publications of the headquarters in Jos JIBWIS (n.d.): al-Jama'a fi Sutūr (the Organization in a few lines), National Headquarters, Jos, Nigeria, Abdulazeez Printing Press Ltd. This booklet is written in three languages (Arabic, Hausa and English, and provides important information on the structure of Izala movement and the duty of the different councils and committees of the Organization. The document also provides a statistical overview of the different instituions under Izala movement.
} 


\section{The Council of 'ulamä}

The 'ulama' constitute one of the most important categories in the hierarchy of the organization. The Izala movement needs well-educated Islamic scholars who are familiar with Islamic tradition and law, on the one hand, and are experienced in preaching, on the other. The 'ulam $\bar{a}$ ' can be considered the "elementary capital" of the Izala movement. They organize preaching and seminars, give lectures, fix the guidelines of the organization, and provide adherents with written material. Being an 'álim (in Arabic: singular of 'ulama $\vec{a}$ ) requires deep knowledge of Islam, the different schools of thought among Muslims, the Quranic text, and the tradition of the Prophet. Apart from traditional Islamic education and mastery of the Arabic language, many contemporary 'ulam $\bar{a}$ ' of the Izala movement attended (and still attend) universities and acquire official diplomas in various fields.

\section{The Administration Council}

The task of this council is defined by the Izala Jos branch in the following way: the Council implements decisions undertaken by the Council of 'ulamä. It reports suggestions of the different committees. It supervised the achievement of projects or programs and it clarifies questions with respect to the organization's belongings and protects them (JIBWIS n.d.: 5). One of the crucial problems leading to the division of the Izala movement was the discussion about whether the Council of Administration headed by Alhaji Musa Mai Gandu is higher-ranking than the 'ulamä' Council, or vice versa. The Kaduna faction still supports and considers Mai Gandu to be the Izala leader. The Jos branch considers the council of 'ulama' to be the highest authority in the organization. The entourage of Mai Gandu tried to impeach Sheikh Idris at the beginning of 1991. During the same period, Sheikh Idris, as well as some of his followers, excluded Alhaji Mai Gandu from the Izala movement. These events within the Izala movement are qualified by Loimeier as a "crisis of orientation" in mid-1991. This crisis took on another turn a few months later after the death of Sheikh Gumi, who was considered to be the "spiritual father of the Izala movement" (Loimeier 1997b: 8).

\section{The First Aid Group (FAG)}

The First Aid Group was formed in 1978 to assist in the logistics of the organization and give practical assistance to the two other Izala councils. The First Aid Group is organized hierarchically from the local level, then the state, and finally the national director. Members of the First Aid Group are trained in first aid basics. They practice sport in order to be ready for intervention. They wear uniforms and are easily identifiable. During Izala gatherings, the First Aid Group is responsible for organizing the meetings and to uphold the order. They control the traffic in front of mosques during times of prayer and collect alms after the prayers. Due to their training in first aid, they 


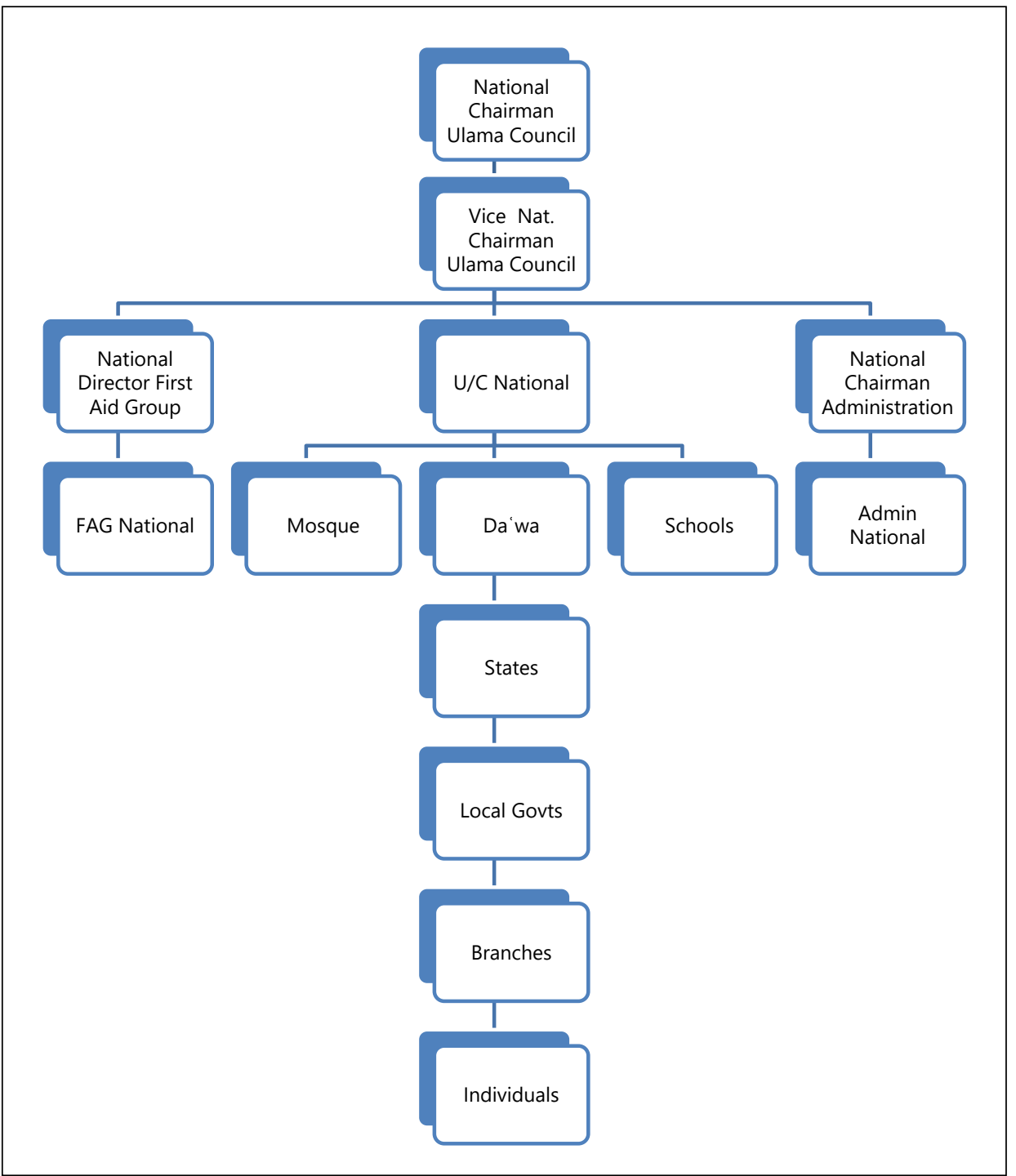

The administrative set up of the Izala organization (according to JIBWIS n.d.: 58)

assist weak, injured, or sick people before bringing them to a medical doctor or to the hospital. The First Aid Group is active in Islamic charity projects. They even plant trees and repair roads. Besides such basic tasks - like maintaining religious facilities the First Aid Group manages more complex duties like assisting pilgrims at airports (JIBWIS n.d.: 22-24). 
At the top of the organization is a national director who controls the organization at a national level. A state director of the First Aid Group has the same duty at the state level. On the local government level, a division leader is responsible. At the district level there is a detachment leader. Concerning the ward level there is a unit leader. This structure mirrors the Nigerian state. All these directors are supervised by a committee. The First Aid Group has its own regulations that assign duty, dress and grades at all levels (JIBWIS n.d.: 24-25 and 72). The First Aid Group opposed the participation of women with the argument that such a participation lead to ikbtilat t (in Arabic: mixing of men and women in public). First aid groups of other Islamic organizations encouraged the participation of women with the argument that "a woman should assist her sister when it is necessary" (Lawal Adam 1992: 43).

\section{Other Committees ${ }^{168}$}

The three councils mentioned above are complemented by different committees that are established according to the needs of the organization and are specialized in particular matters. The Jos branch counts five different committees for education, finances, health and welfare, personal and discipline as well as the committees of elders.

a) The education committee is responsible for the educational system of the organization and is under the supervision of the 'ulam $\vec{a}$. This committee is responsible for preparing curricula and providing materials for schools. The organization also made efforts to obtain recognition from the state. The Director of the Diploma Section, Sarkin Mangu, Ustaz Nasir Abdelmuhyi ensured that the examinations of the Izala movement are recognized by the Ahmadu Bello University (ABU). ${ }^{169}$ Students who have completed their threeyear diploma from the Izala High School for Islamic Studies can join ABU in their second year. The educational system of the Izala movement consists of schools from nursery to the diploma level. There are also certificates that are issued by the Izala movement, State ministry of Education, ABU Zaria, or by the Institute of Education in Bauchi after an accomplished period of studies. Nursery school for example lasts three years and is under the supervision of the State Ministry of Education, while the primary school, called Majlis asSunnah, is under the supervision of the Directorate of education of JIBWIS. The Izala movement defines thirteen types of schools with different names, levels, and orientations. These schools are set up in a bottom-up hierarchy;

\footnotetext{
168 Also based on information from the JIBWIS publication; for a comparison with the five committees (finance, guidance, discipline, communication, and central committees) of Izala movement are introduced in the first constitution of the Organization (8 February 1978) see also Loimeier (1997a: 360-366.).

${ }^{169}$ Interview in Jos, 5 December 2006.
} 
the top being the Diploma Section. ${ }^{170}$ Concerning the number of schools, the Jos Branch specifies that, in any local government in Nigeria where members of the Izala movement reside, there should be two primary schools: one Arabic/Muslim-style and one Western-style education school. At the state level, a tahafìz (in Arabic: Qur'ān recitation school), secondary and Higher Islamic Studies schools are found (JIBWIS n.d.: 64). In 2000, the Jos branch counted one Diploma Section school and eighteen Higher Islamic Studies Schools in eight different Nigerian States. The organization has four preparatory and secondary English schools in three different states. Among the concerns of the organization is the establishment of schools for elderly people. The Izala movement lists ninety Saturday/Sunday schools in eight different states. Quranic schools are also an important part of the educational system. There are fifty-two Quranic schools in ten states and the so-called Martau Awlad (Quranic School for children) with one in Jos and one in the Republic of Niger (JIBWIS n.d.: 15-17).

b) The committee of finance has the duty to supervise the economic aspects of the organization. It also proposes budgets as well as expense reports to the Administration. The committee of health is concerned with building hospitals, centers for orphans and widows, and introducing programs for disease prevention.

c) The committee for personal matters and discipline is under the supervision of the administration council. It organizes employment, promotion and suspension of staff. The elders committee has an advisory task to direct the organization to conform to the Qur'ān and the sunna (JIBWIS n.d.: 6-7).

There are also other mosque committees. These committees are set up for every mosque and consist of seven members (head, secretary, the imam, the muezzin, and three other people). They are controlled by the council of 'ulamä. Mosques are built through collecting alms or through donations from individuals, the state, or Islamic associations. A committee for sulh (in Arabic: reconciliation) comprised of 'ulamä' is charged with resolving disputes between Muslims according to the Qur'ān and the sunna. Another important committee is that of preaching, which is organized according to the different levels mentioned above (local, state, national, and international). This committee is concerned with dawa activities. It organizes meetings for imams and propagates Islamic knowledge through mass media, publications, cassettes, and videos (JIBWIS n.d.: 8-10). The Qur'ān recitation competitions belong to the most

\footnotetext{
170 Asas Nursery ( 3 years), Asas Primary ( 6 years), Maljaus Sunnah Primary School ( 5 years), Sat/Sun Mutawassit School (3 or 4 years), Upliftment School (3 years), Tahafīz School ( 5 years), Junior Islamic Studies (3 years), Mu'assasa School (6 years), Senior Islamic Studies (3 years), Junior Sec School (3 years), Senior Sec School (3 years), and finally Diploma in Arabic and Islamic Studies; For more details see JIBWIS (n.d.: 63-64).
} 
prestigious activities of Izala movement. They were established in Nigeria in 1986 and Izala movement members have participated in it since 1987. These competitions follow the example of Saudi Arabia, which started these contests in 1979. These activities encourage young people to study the Qur'ān. The Izala movement introduced such activites at all levels and there is a committee that organizes these events as well as a jury of fifteen members under the direction of the leader of the council of 'ulama' (JIBWIS n.d.: $18-20)$.

\subsubsection{The current leadership of the Izala movement ${ }^{171}$}

The split of the organization led to a division at the level of leadership as well as between the two highest councils of the Izala movement. The 'ulamä' are in the leading positions of the organization for the Jos branch. This is confirmed in the new draft of the organization (see section "one constitution and two factions...”). These events led to a struggle for identity and authenticity within the movement. Neither of the two branches was ready to give up the name or the constitution. Both still refer to Jos as the origin of the movement. Both groups still refer to the initial objectives of the organization and ensure that the division has nothing to do with faith-based issues, but rather with ideological and organizational matters.

\section{The Jos branch of the Izala movement}

The founder of the organization and leader of the 'ulama' was the late Sheikh Ismaila Idris (d. 2000). His deputy was Sheikh Uthman Muhammad until his death in Zaria in 1991. Sheikh Sani Yahya Jingir took over as Idris' deputy and became the head of the organization and its council of 'ulam $\vec{a}$ ' from 2000 until today. His deputy is Sheikh Alhassan Said Jingir. Most, if not all, Izala institutions (schools, hospitals, shops, etc.) related to Jos have the marker "Jamāat Izalatul bid'a Wa Iqamatis Sunnah allati assasahā Sheikh Ismaila Idris" (JIBWIS founded by Sheikh Idris). It is always indicated on the first page of Izala publications that Jos is the national headquarters. Again, this is a sign of authenticity from this branch of the movement.

The current Izala movement leader, Sheikh Sani Yahya Jingir is regarded as a distinguished scholar in northern Nigeria. He was born in 1950, and originates from the Bassa local government in the Plateau State. He is fluent in Arabic and has studied the Qur'ān since his childhood. He worked as primary school teacher. He joined the Islamic Institute of Teachers in Jos and later moved to Maiduguri, where he completed secondary school. In 1984, he went to Kano where he later received a Diploma in Arabic and Islamic studies. In 1997, he went back to the University of Jos where he com-

\footnotetext{
${ }^{171}$ Most of the written material (pamphlets, booklets, copies of ceremony) collected is largely from the Jos branch of the Izala movement. This is not due to a personal choice but rather to the availability of the material. The Jos branch of the Izala movement seems to be more productive when it comes to publications.
} 
pleted his studies in 2001 with a B.A. in literature and education. In Jos, Sheikh Jingir served as the director of the School of Higher Islamic Education for ten years and contributed to the spread of the Arabic language as well as to the da'wa of the Izala movement in some areas of Nigeria. ${ }^{172}$ Sheikh Jingir is the head of the council of the 'ulam $\vec{a}$ for the Jos branch of the Izala movement. After the death of the founder, he became the highest religious authority of the movement. He is still very active in preaching, present in the mass media, and the first speaker of the Izala movement in Jos.

Fatwäs expressed in his preaching, seminars, meetings and lectures are either recorded or printed and circulated among the Izala Jos followers. The leader also has several publications edited by the headquarters that deal with different subjects. To reach a large readership, these publications are published in Hausa, Arabic and English. The main topics of these publications are focused on specific religious matters, such as sacrifice, leadership, and tawhid, which is a central concept in the doctrine of Izala movement.

Sheikh Jingir introduces his view on this concept in a publication in Arabic. ${ }^{173}$ Tawhìd is related to the number "one" (in Arabic) and al-Wähid (in Arabic: the Unique, the only One) is one of the ninety-nine names of Allah. There are two different types of tawhid:

a) Oneness of God (Arabic: tawhìd al-rubübiyya) with respect to names (Arabic: tawhìd al-asmā) and attributes (Arabic: tawhìd al-sifät).

b) Oneness of God with respect to actions (Arabic: tawhid al-talab) and intentions (Arabic: tawhìd al-qașd).

The oneness of God is a central doctrine for every Muslim. All the prophets invited humanity to believe in the oneness of God and the term is mentioned in the Qur'ann several times. The Prophet Muhammad also spent several years calling people to tawhid (Jingir 2006: 4-5). ${ }^{174}$ The advantages of tawbid are summarized by the Izala movement leader in three major points: through tawhid one achieves the guidance of Allah, spiritual tranquility and peace (Arabic: sakina) as well as the unity of the umma (in Arabic: Islamic community) (Jingir 2006: 7-10).

After elaborating on the concept and its different categories, Sheikh Jingir emphasizes how polytheists are in a status of anxiety and skepticism and contrasts them with believers [monotheists] and their status of peace (Jingir 2006: 19-29). Speaking of tawhid led Sheikh Jingir to reject Sufism and the Sufi way of worshipping God. For

\footnotetext{
${ }^{172}$ For his biography in the Arabic language, see Jamila Adam Abdallah (2005: 54-55). For a more detailed biography in the Hausa language see Muhammad, Salihu Idris (n.d.): Gwagwarmayar. Sheikh Sani Yahaya Jingir (the Struggle of Sheikh Sani Yahaya Jingir).

173 See Jingir, Muhammadu Sani Yahya (2006): tawjīh al-tạlib ilā 'ibādat Allāh 'ibadatan wa-mưāmala (Guidance of the Student to the Oneness of God in the context of worshipping and religious transactions), Jos: JIBWIS-Headquarters.

${ }^{174}$ For this differentiation, the author relies on the categorization by Ibn al-Qayyim al-Jawziyya (d. $1350)$.
} 
the author, worshipping Allah is based on three basic elements, namely, mababba (in Arabic: love), rajāc (in Arabic: supplication) and khawf (in Arabic: fear). In the case of Sufism, the relationship between God and his worshippers is based on 'ajab (in Arabic: wondering) and loving the Prophet in a way different from Allah's guidance (Jingir 2006: 29-32).

Leadership is one of the most controversial issues in the Izala movement. The organization's split took place because of a struggle for leadership. Sheikh Sani Yahya Jingir points out that leadership starts at home until it reaches the global level. He confirms that leadership needs obedience and that the "absence of leadership led to anarchy and insecurity" (Jingir 2006: 3). Leadership is as old as Islam and goes back to the time of the Prophet. All successors followed his leadership in the context of religion (Arabic: din) and state (Arabic: dawla). Sheikh Jingir insists on the concept of bay'a (in Arabic: oath of allegiance to a leader), which means the obedience to the leader and his leadership (Jingir 2006: 7-16). Jingir insists that leadership requires piety, i.e., fearing Allah and following His Prophet, trustfulness, and just deeds. ${ }^{175} \mathrm{His}$ arguments are complemented by references from the Qur'ān confirming his point of view. Finally, Sheikh Jingir stresses the importance of $s h \bar{u} r \bar{a}$ (in Arabic: consultation) within the context of Islam and leadership, and considers it to be compulsory for any leader in order to avoid "dictatorship and anarchy" (Jingir 2006: 25). This publication reflects Sheikh Jingir's views on leadership and can be considered a general overview of the concept. It can be considered by Muslims in general, and by Izala members in particular, as a guide for following their leader and not deviating from him. In my opinion, this booklet is an implicit message to all those who split from the Izala founder and deviated from his path. If Sheikh Idris requires adherence to all the features described by Sheikh Jingir, then the division from him was not based on comprehensible reasons.

In addition to the 'ulama' of the Jos faction, who lead the organization, the other two councils play a crucial rule in facilitating the achievement of the leaders' ideology. The Council of Administration has been headed by Alhaji Ibrahim Na Alhaji Azare since the death of the former leader Alhaji Habibu Gado Damasu. His Deputy is Alhaji Marafan Tambuar, and the Secretary of Administration is Alhaji Abdurrahman. Concerning the FAG, the national Director is Alhaji Captain Issa Waziri and his deputy is Alhaji Ibrahem Shuayb. The secretary of FAG is Alhaji Muhammad Abubakar. ${ }^{176}$

\footnotetext{
${ }_{175}$ As part of the qualifications of the leader, Jingir lists twelve points of a successful leadership in Islam: purity of intent, humility and modesty, patience and perseverance, being calm and gentle, being subtle and forgiving, being kind hearted, leading by example, being honest and sincere, has the ability to reward good words and punish bad ones, considers specialization when attending to the division of labour, accepting criticisms, and being moderate, see Jingir (2006: 22-23).

176 Interview in Gombe, 20 February 2008, with Captain Alhaji Issa Waziri, the National Director of the First Aid Group of the Izala movement, Jos branch.
} 


\section{The Kaduna branch of the Izala movement}

The Kaduna faction of the Izala movement does not accept the leader of the Izala movement in Jos. In Kaduna, Alhaji Musa Muhammad Mai Gandu is regarded as the head of the Izala movement as a whole. It is interesting to note that he was not among the religious scholars, but only headed the Administration Council during the lifetime of Sheikh Idris, the founder. The leader of the Izala movement in Zaria insists that the current leader of the Izala movement and even during the lifetime of Sheikh Idris was and is Alhaji Mussa Mai Gandu:

The people of Jos are hardliners in the context of this conflict. They want to keep the conflict to prove that they were the initiators of the organization. This is not true because the first leader of the movement was Mussa Muhammad Mai Gandu - he is still alive - and the people of Kaduna are to this day on his side. Mai Gandu was the first leader and even Sheikh Ismaila Idris was under his authority. ${ }^{177}$

Most names given to the government for official registration of the Izala movement were from the Kaduna faction - five altogether. Two of them already passed away, but three are still alive. From the three alive, two of them are with the Kaduna branch and only one with Jos. ${ }^{178}$

Alhaji Musa Mai Gandu was born in 1930. He is a businessman who was active in the politics of northern Nigeria. He used to be a member of the Northern People's Congress (First Republic) and later was a member of the National Party of Nigeria (Second Republic) (Kane 1994: 498). He supported the Izala movement financially even before it became recognized as an official organization,. He served as the chairman of the Elders Committee. The actual national chairman of the Council of 'ulama' of the Izala movement, Kaduna faction, Sheikh Yusuf Muhammad Sambo Rigachikum insists that Alhaji Mai Gandu was and still is the leader of the entire organization: "Alhaji Musa Muhammad Mai Gandu is the leader of the organization. The leader even before the name was given to the organization. He was the first leader, and still is the leader, and has never been impeached by any person." 179

Sheikh Yusuf Sambo insists that during the founding stage of the Izala movement and during an early meeting in Kaduna, Sheikh Rabiu Daura, who is actually the chairman of the council of 'ulama' of Kaduna State (with the Kaduna faction of the Izala movement), was nominated to become the head of the council of 'ulamáa of the

\footnotetext{
177 Interview in Zaria with Ali Abdallah Telex, 7 January 2007. He is an Imām, advisor and member of the Council of Ulama. He is affiliated with the Kaduna faction of the Izala movement.

${ }^{178}$ Interview in Zaria with Ali Abdallah Telex, 7 January 2007. My interview partner mentioned the name of Sheikh Cikaji, Sheikh Yakubu Musa (Izala Kaduna), Sheikh Alhassan Said (Izala movement Kaduna), and Captain Isa Waziri (Izala Jos). He could not remember the fifth name.

${ }^{179}$ Interview in Arabic with Sheikh Yusuf Sambo in Kaduna; 15 January 2007 (my translation).
} 
organization. Since Sheikh Idris was the founder of the Izala movement, the decision was to appoint him as the head of the council of 'ulamä..$^{180}$ Alhaji Mai Gandu's nomination as leader of the Izala movement initiated a controversial debate. The entourage of Sheikh Idris refused to accept a person who is not an Islamic scholar, álim, as head of the directing committee of an Islamic organization like the Izala movement. The leader of the council of 'ulamä' in Katsina (Kaduna branch), Sheikh Yakubu Musa Hassan (Kafancan) clarifies:

(...) the followers of Sheikh Idris claimed that Alhaji Mai Gandu was not an 'âlim [Islamic Scholar]. We answered that we were aware of that and we elected him as a leader of the organization. How can we remove him from his position when the organization became stronger and more successful among people under his leadership? ${ }^{181}$

The organizational structure of the Kaduna faction of the Izala movement is comparable to that of Jos. In every state, there are three levels of leadership of the organization, namely the level of local government, the level of the federal state and finally at the national level. The Kaduna Izala faction is active through preaching. Topic(s) like zakāt, țalāq, or nikāh at any religious gathering are announced in advance on the radio, and people travel to the mentioned preaching-place. Preachers normally travel Saturday for da'wa activities and come back home on Sunday. The so-called wa'z (in Arabic: preaching, moralizing) usually takes places once a month in the federation. At the state level, this activity happens semi-monthly. The Izala movement faction in Kaduna is financially assisted by wealthy people and through the contributions of its members. The organization has its own schools, mosques, hospitals, and pharmacies. There is a chairman who is responsible for mosques and schools. There is also a leader appointed to manage $d a^{c} w a$ activities. The current chairman of $d a^{c} w a$ is Sheikh Yakubu Musa Kafancan. ${ }^{182}$

Speaking of the contribution of the Izala movement to Islam, Sheikh Rabiu Daura refers to the several Qur'ānic schools that attract many people. The activities of Izala movement vary from calling people to teaching about the oneness of God, the Qur'ān (recitation, exegesis), and Islamic law. As a result of the organization's work, Sheikh Daura mentions that more women are wearing bijäb (in Arabic: veil) and more young people (between 15 and 16 years) are studying and memorizing the Qur'ān. In the beginning of the Izala movement, there were only two mosques in Kaduna, where Sheikh Daura is based. Now there are seventy-five Friday-mosques and many Islamic

\footnotetext{
180 Interview in Arabic with Sheikh Yusuf Sambo in Kaduna; 15 January 2007 (my translation).

181 Interview with Sheikh Yakubu Musa Hassan (Kafancan) in Katsina, 12 March 2008.

182 Ibid.; Sheikh Y. Sambo could not give any official statistics about schools or other institutions of the organization.
} 
schools. His organization is also active in other countries like Togo, the Republic of Niger, Cameroon, and Chad. ${ }^{183}$

In 2005 the Kaduna branch counted thirty-three sheikhs and mallams who were active in preaching and propagating the message of the organization. These scholars are active in different parts of northern Nigeria (like Sheikh Yusuf Sambo in Kaduna, Sheikh Usman Isah Taliyawa in Gombe, and Sheikh Alhassan Said in Jos. Sheikh Abdullahi Sale Pakistan in Kano, and Dr. Ibrahim Jallo in Jalingo - to mention a few), but also in the south of the country (like Sheikh Buhari Yakubo in Lagos) or in the east (Sheikh Abdullahi Bala Lau in Yola, Adamawa state.). The organization also has thirteen Qur'ān reciters or alaramomi (sing. alarama, in Kanuri language) - as they are known locally. ${ }^{184}$ Like the Jos faction, the Kaduna faction has its own First Aid Group. The tasks and duties of both First Aid Groups - Jos and Kaduna - are the same. In fact, First Aid Groups are a crucial part in many Nigerian Islamic organizations, not only in the Izala movement. Their role is indispensable in logistics and organization as well as in assistance work. The First Aid Group of the Kaduna faction is headed by the Zaria-based leader and National Director, Mustapha Imam. The two First Aid Groups of the Izala movement are under the national supervision of the organization. Apart from that, there are leaders at the state, division, and detachment level. In Nigeria, Izala Kaduna has one General Director, thirty-one state directors, and every state director has thirty-two officers. There is also a divisional leader under which there are twenty-four officers (division refers to local government). Concerning the detachment leader of the First Aid Group, there are twelve officers under his supervision. The lowest level is that of unit leaders (small area). First Aid Groups assists in fire and water disasters, and they also take care of hajj and pilgrim matters. They give assistance to hospitals and cooperate with the government. Most First Aid Group members rely on donations from wealthy people or they get assistance from the government. ${ }^{185}$

Apart from the 'ulama' and the First Aid Group, the Izala branch of Kaduna also has a council responsible for administrative matters. ${ }^{186}$ In addition, there are several committees established to facilitate the activities of the organization. Amongst others, there is a committee responsible for education and the educational programs of the organization. There is also a committee for fatwās concerned with legal aspects as well as facilitating the work of the Islamic scholars. Another important committee is responsible for da'wa activities. Izala Kaduna also has a committee responsible for the printing, publication, and translation of material used by the organization in both education and preaching. The committee of finances is responsible for the monetary

\footnotetext{
183 Interview with Sheikh Rabiu Daura in his House in Kaduna, 15 January 2007.

${ }^{184}$ See more details in Rigachikun (2005), a text written in Hausa explaining the system of the Izala movement as well the way of preaching of the organization). The Qur'ān recitors are in Katsina, Kaduna, Kano, Gwando, Gusau, Argungu, Shendam, and Gashuwa.

${ }^{185}$ Interview in Zaria with the General Director of FAG, Kaduna Branch, Ustaz Mustapha Imām, his House, 8 January 2007.

186 The material I collected on the Kaduna faction does not include information on that council of the organization.
} 
aspect. Finally, there is a committee of revision, which revises the work of imāms and preachers, and controls the processes of education. ${ }^{187}$

\subsection{The Izala movement and innovation}

Since its establishment, the Izala movement has considered fighting bid' $a$ a crucial element on which the entire organization is based. This concept is not only to be found in the official name of the organization: "Jamāat Izalatul Bidá..." (Society for the Removal of Innovation...), but also reflects its doctrine and understanding of Islam. In the coming paragraphs, the concept of bid' $a$ is introduced and analyzed from different angles. Dealing with the concept itself is by no means an attempt to reach a final definition or to legitimate its use(s) or mis-/understanding; rather, it is instead an attempt to show the complexity of a notion like bid'a. The discourse surrounding bid' $a$ among the Izala themselves as well as between the Izala movement and tariqas seems to be more fruitful to look at. The discussion on the concept and the way in which the Izala movement uses it makes it more interesting than any other concept used by the movement.

\subsubsection{Definition(s) of bid'a}

In the Arabic dictionary al-Munjid fi-l-lugha w-al-Aläm of 1986, we find five different forms of the root (b, d, 'ayn) from which the word bid' $a$ is derived:

a) "badac'a" means to invent something and create it without following a model; concerning the concept bid'a (pl. bida') it means "what was established without being there before"; one of the names of Allah is "al-Badī" - which is mentioned in the Qur'ān - it means the Creator (of Heaven and Earth); "alMubtadi'" is the one who creates something new.

b) "badda'c" means someone related to bid'a; "ibtada'c" means somebody comes out with a bid'a; (bida' in plural) is a doctrine (Arabic: 'aqìda) different from faith (Arabic: $i m \bar{a} n$ ); "Mubtadi' ūn" are those who come up with bid'́.

c) “abda'a” means somebody does his work perfectly.

d) "istabda'a" signifies being astonished by something.

e) “abdaca (bihi)" means to ignore something and abandon it (al-Munjid 1986: 29). ${ }^{188}$

\footnotetext{
187 See more details on these committees in Rigachikun (2005: 42-46).

188 This is only a sample from the mentioned dictionary. There are several other meanings and categorizations of the term.
} 
In his article on bid'a for the first edition of The Encyclopedia of Islam, D. B. MacDonald defines bid' $a$ as the opposite of the sunna. The concept can be understood as "innovation or novelty". The word bid'a developed into a "theological keyword" connoting "new ideas and usages ... not in accordance with the traditional sources (usiul) of the Faith" (i.e. the fundamentals of Islamic jurisprudence, RbA). The expressions "individual specific point of view", "legal entity" and even "heresy" are also related to the concept of bid'a as they are linked with the concept of kufr (non-belief). MacDonald adds that in dealing with bid'a, two main points of view have developed over time: One is conservative, and the other is liberal. The first one - basically the Hanbali School of Law and the Wahhābī Doctrine - follows the sunna and rejects bid'a, while the second (liberal) deals with the development of the concept and categorizes bid'a under several categories (necessary, good, bad, rejected, possible - to mention some) (MacDonald 1913: 742; translation RbA).

In the second edition of The Encyclopaedia of Islam, J. Robson points out that bid'a is understood by some Muslims as "something that must be wrong". In fact, there is a distinction between a good or praiseworthy (Arabic: bid'a hasana or mabmüda) and a bad or blameworthy innovation (Arabic: sayyi'a or madhmüma). This differentiation is a "necessary principle." The author indicates that, according the Shāfi i $\overline{\text { School }}$ of Law, any bid'a contradicting the Qur'ann, sunna, consensus, and the tradition of the Companions can be considered to be "erring innovation," but any bid'a not contradicting these sources can be seen as praiseworthy. Robson identifies the following categories of bid' $a$ in the Islamic tradition: prohibited (Arabic: mubarrama), recommended (Arabic: mandība), disapproved (Arabic: makrūha), and permitted (Arabic: mubaha). He adds that bid'a is distinguishable from heresy. An innovator is defined as "one who introduces something on an arbitrary principle without having any basis in the recognized foundations of Islam" (Robson 1960: 1199).

Bid'a is explained by Robson as "innovation, a belief and practice for which there is no precedent in the time of the Prophet" (ibid.). Also in the second edition of the Encyclopaedia, İnalc1k gives an example of how bid'a was understood by the Ottoman administration; bid' $a$ was seen as a contradiction to the shari' $a$ and the "Ottoman principles." The Ottomans differentiated between two types of bid'a, namely, "bid'at marfu'e" which means, pre-conquest taxes and dues that were "abolished by the sultan's specific order", and "bid'at ma'runfe" which are pre-conquest taxes and dues that were "customarily recognized" (İnalc1k 1995: 486).

The well-known program in Arabic countries "al-sharīa wa'l-hayāt"189, aired on 24 January 2008 by al-Jazeera, was devoted to discussing the issue of bid'a: "al-bid'a wa-majālātubà al-mu'assira" (in Arabic: innovation and its contemporary fields). The

\footnotetext{
189 This is a weekly platform to discuss religious, social and political issues of the Islamic Society. Every week a prominent Islamic scholar is invited to talk on a particular topic. People from all over the world can call and raise questions to the expert. The entire show is then recorded live; all speeches are transcribed and archived online, where they are accessible to the general public (see https://www.aljazeera.

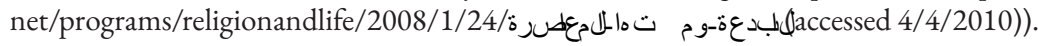


Syrian Islamic scholar and law expert Wahba Zuhayli was invited to speak. Zuhayli began by mentioning the famous hadìth "kullu bid'a dhalāla wa kullu dhalāla fi-lnär" (in Arabic: every innovation is an errancy, and every errancy leads to hell) and raised a number of questions dealing with the essence of bid'a, as well as theological discussion(s) on the concept and the contemporary fields of bid'a. Wahba Zuhayli begins his statement by illustrating the difference between bid'a and sunna. According to him, "sunna is what was transmitted from the Prophet (PBUH) and everything contradicting and deviating from it is considered bid'a." The prominent scholar adds that something can be considered bid'a if it is associated with issues of 'aqida or 'ibādāt (in Arabic: worship). This led the Sheikh to differentiate between bid'a, which contradicts basic elements of faith or worshipping, and $i j t i b \bar{a} d$, which exists within the Islamic shari' $a$. The fundamental difference that he points out is that bid'a - in contradiction to ijtib $\bar{a} d$ - lacks proof. Concerning the question of the relationship between innovation in religion (Arabic: ibtidä́f fil-din) and non-belief (kufr), the Sheikh mentions that an innovation can lead to non-belief if it falls in the context of 'ibādāt or muamalāt (in Arabic: worship or human transactions). He mentions the example from the history of Islam when the group of "al-Mushabbaha" who identified the dimensions of the Creator (God) or the group of "al-Mujassama" who described the Creator as having a body. These examples can be considered kufr. Sheikh Zuhayli confesses that the understanding and interpretation of the concept is in many cases exaggerated and returning to the basic sources (Qur'ān and sunna) of Islam solves this problem. When it comes to a contemporary issue such as visiting the tomb of the Prophet during pilgrimage, celebrating the Prophet's birthday, or even 'Isā’s (Jesus) birthday, the Sheikh considers such practices to be bid'a except if the reason behind them is seeking thawāb (in Arabic: reward) and by no way imitating others or expressing regards or exaltation to a particular person. He concludes that personal intention (niyya) is crucial in deciding whether it is a case of bid'a or not. ${ }^{190}$

Historian Bernard Lewis deals with the complex concept of heresy in Islamic history and shows the existence of more than seventy-two terms connoting heresy (see Lewis 1953: 43-63). These words have different meanings and reflect in no way the exact expression of "heresy" as understood in the Christian sense. The term bid'a is one of these meanings of heresy. B. Lewis understands bid' $a$ as "innovation, and more specifically any doctrine and practice not attested to in the time of the Prophet. The term is thus the opposite of sunna" (Lewis 1953: 52). Lewis sees the "extreme" form of bid' $a$ as everything not identified during the time of the Prophet or the time of his companions. In his later analysis, Lewis differentiates between a "good" and a "bad" innovation. This distinction is based on the so-called ijma $\bar{a}$ or consensus of the Muslim community, and because of that, the author claims that "the bid'a of today may

\footnotetext{
190 https://www.aljazeera.net/programs/religionandlife/2008/1/24/accessed $4 / 4 / 2010$ ); the printable version of the discussion is comprised of eight pages. In reflecting the point of view of Sheikh Zuhayli, a summary of his views is given rather than quoting his statements and indicating the number of the page(s).
} 
become the sunna of tomorrow ... since bid'a may thus vary with place as well as time" (Lewis 1953: 53). The author concludes that, although in some contexts bid'a is translated as heresy, both are "far from being exact equivalents" (Lewis 1953: 53). ${ }^{191}$

Mohammed Talbi, an Islamologist, considers the discussion on bida' (he uses the plural of the term) as "rich and promising" when dealing with the development of fiqh and generally with the Islamic civilization (Talbi 1960: 43). Talbi thinks that, because of the historical context of the mid-first century bijri (622 CE), anything "nouveau" (new) became a synonym for "condemnable" (condemnable, rejectionable) (Talbi 1960: 46). Talbi considers the first three generations after the Prophet as a period during which the big theories of fiqh were largely developed. During that period, two concepts were common to people: bid'a and mubdath (new). In the next two centuries, intensive engagement with $b i d a^{c}$ as a notion took place. It was during the first century of Islam that the concept was developed, but the author sees the second century in which the important books of fiqh were written as a more significant period. In the context of defending dār al-Isläm (house of Islam) from novelty/innovation, the issue of bid'a and the entire discussion behind it represented an "aspect of defence" (Talbi 1960: 48-49). Talbi draws attention to the idea that bid'a is related to the concept of sunna. Both are interrelated and represent two sides of the same coin, butone is positive and the other is negative: "bid'a and sunna were inseparable and correlative. They constituted the two aspects of the same ideal order that we tried to follow on immutable basis - two faces of the same reality. If one (of the two) taught what should be avoided, the other proposes the model to be followed" (Talbi 1960: 52, translation RbA). Talbi also mentions that the notion bid'a hasana is a result of the "bid'a controversy." Especially in the Shäfi'i School of Law, the notion of muḅdathät (Arabic: novelties; sg. mubdatha) was introduced and differentiated from bid'a (Talbi 1960: 61-64). ${ }^{192}$ Talbi also mentions the well-known division of the concept of bid'a into five categories: obligatory, recommended, illicit, blameable, and licit. ${ }^{193}$ This classification is a model among others. In other cases, bid'a exists only when there is a contradiction to Islamic law. ${ }^{194}$ Far from the meaning of bid'a, Talbi considers it a "phenomenon" and a "tool of social conservatism" (facteur de conservatisme social). In the context of the discussion surrounding bid'a and sunna, reformers have used the former concept to protect the religion of Islam (the Wahhābis' opposition to visiting saints and marabouts, for

${ }^{191}$ In the same context, Lewis discusses other terms like ghuluw, zandaqa, hartaqa, kufr, ilhād, and all of them seem to be complex - as it is the case of bid'a.

192 Talbi mentions that this differentiation (bid'a and mubadatha) or Shāfi ì „solution" - as he calls it - led to the understanding of bid'a as contradiction to usül al-fiqh. The differentiation did not survive may be because it was rejected or ignored - as the author explains.

${ }_{193}$ According to Talbi, this differentiation seems to have been developed during the $13^{\text {th }}$ century especially with Ibn 'Abd al-Salām; for more details see Talbi (1960: 64-66).

${ }^{194}$ In this context, Talbi quotes the Islamic scholar al-Shatebi (d. 1388) who opposed the categorization of bid'a as well the socalled bid'a hasana. According to al-Shatebi can only be understood in relationship to law. Furthermore, al-Shatebi understands bid'a in the context of "cult" ('ibādāt). See Talbi (1960: 66-69). 
example) (Talbi 1960: 71). ${ }^{195}$ As for whether bid'a can be considered innovation in and of itself, Talbi answers: "elle ne l'est pas toujours!" (It is not always the case). It can be something that existed previously, but recently considered to be strange to Islam. By giving this answer, Talbi is aware of the absence of a high authority defining "la veritable orthoxie" (the ideal orthodoxy). The concept of bid'a thus remains dynamic and changeable (Talbi 1960: 75). As a conclusion, Talbi assumes that bid'a cannot be defined through the "domaine assez complexe" (quite complex field) that it covers. It can be more easily defined through the attitude of the authority that condemns it. Talbi sees bid' $a$ as a deviation from the path of sunna - a deviation through ideas considered as "nouvelles" or "extra-islamique" (Talbi 1960: 75).

In his book Muhammedanische Studien, Ignác Goldziher deals with the issue of bid'a. In his approach, Goldziher spoke of the use of "politische bid'a" (political bid'a) during the early stages of Islam. The concept was generally understood as "following law" long before it was specified as "following religious law." The author then referred to the so-called "ritualistische bid'a" (ritualistic bid'a). He situated sunna as an opposite of bid'a. Interestingly, Goldziher related the two concepts to a particular place - Medina. Medina - that he called "house of the sunna" - is considered to be the origin of the Prophetic tradition (Goldziher 1890/1971: 15). The sunna is as old as Islam and developed at an early stage into a "normative principle in the life of $\mathrm{Mu}$ hammedaner" (Goldziher 1890/1971: 19). During the $2^{\text {nd }}$ century of Islam (722 CE), sunna - like the Qur'ān - reached a level of standardization (Goldziher 1890/1971: 20). Later on, the concept of $i b y \bar{a}$ ' al-sunna (revival of the sunna) appeared as in opposition to imātat al-bid'a" (killing of innovation) (Goldziher 1890/1971: 22). According to Goldziher, "Muhammadan theologians" understand two different types of bid'a: practical (every practice that was not exercised during the time of the Prophet) and dogmatic (heresy). Goldziher proposed a simple definition of bid'a as an "arbitrary individual insight whose admissibility to religious sources is not documented" (Goldziher 1890/1971: 23).

Maribel Fierro, a historian of Islam, offers an overview of writings on bid'a from the history of Islam and focuses on two of the oldest treatises, namely, that of Ibn Waddah (d. 900) and that of al-Turtushi (d. 1126) dealing with the issue of bid'a. First of all, the author indicates that the term bid'a has a negative connotation in an Islamic context. The meaning of bid' $a$ in the Islamic legal tradition deals with innovation in rituals and practices and also with dogma (Fierro 1992: 204). ${ }^{196}$ Fierro stresses that accusations of bid'a can happen within an Islamic School (institution against individual) or between two different institutions (institution against institution). Accusations can also occur between Sunni and non-Sunni Muslims (Fierro 1992: 206), The author sketches a list of "kutub al-bida" (books of innovations) dealing with specific inno-

\footnotetext{
${ }^{195}$ As part of the Wahhabiyya use of the concept of bid'a, Talbi mentions Muhammed Abdu and Rashid Ridha who criticized the situation of the Islamic umma. Both Abdu and Ridha gave the spread of bid'a as an explanation for the stagnation of Islam.

196 Fierro relies on the publications of Goldziher, MacDonald, Talbi, and Lewis summarized above.
} 
vations. ${ }^{197}$ Within the Māliki School of law, the issue of innovation goes back to the end of the eight century (CE). The topic was also presented and discussed by Islamic scholars during the ninth, tenth and eleventh centuries (CE) in North Africa (Fierro 1992: 210). ${ }^{198}$ Although a number of scholars handled bid'a, Maribel Fierro considers Ibn Waddah to be the first who directly wrote a treatise on the subject. Concerning al-Turtushi, he is also seen by the author as an authority that influenced literature on bid'a. Both are Mālikī scholars of Andalusian origin.

Maribel Fierro thematizes the issues considered to be bid' $a$ as discussed by the two writers (see Fierro 1992: 213-240). The first point concerns the recitation and writing of the Qur'ān. Both Ibn Waddah and al-Turtushi criticized the so-called qiräa bi'l-alhạn (Arabic: musical recitation) stressing that it influences the meaning of and comprehension of the Qur'anic text - apart from the fact that it is un-Islamic. Also, qiräa bil-idāra was also criticized. In this case the recitation is performed simultaneously and there is no possibility to both listen and understand the text. Another innovation identified by al-Turtushi in the context of the Qur'ann is reciting the text for money, or reciting the Qur'ān quickly without understanding its meanings. He also criticized dividing the written Qur'ān into small parts, numbering the verses of each sürah or punctuating the text.

The second field of innovation is the mosque. According to Fiero, al-Turtushi sees the mibrab (Arabic: niche in the wall of the mosque indicating the direction of Mecca) as an innovation. An imām should not stand in it, and it should not even be decorated by Qur'ānic text. Decoration of mosques was rejected by al-Turtushi since it "corrupts" people. Ibn Waddah criticized the practice of ittibā' āthār al-Nabi (Arabic: following the steps of the Prophet), in particular praying in places where the Prophet prayed. There is a risk that they will be transformed into sanctuaries. Al-Turtushi also criticized putting boxes in mosques for the collection of alms, eating and drinking in mosques, making noise, writing copies of the Qur'ān in the mosque, etc. When it comes to the mosque of Mecca, al-Turtushi criticizes "raising the hand in front of the Ka 'ba" since it is a Jewish practice. Concerning the Mosque in Medina, he rejected the practice of touching the tomb of the Prophet.

The third field of criticism concerns the month of Ramadan. Al-Turtushi considers the taräwi h̆-Prayer in Ramadan to be recommendable, but criticizes some practices associated with it, such as the mixing of men and women. Both Ibn Waddah and alTurtushi denied celebrating the night of mid Sha'ban or fasting the whole month of Rajab, celebrating the day of Arafa ( $9^{\text {th }}$ of the month Dbu'l-Hijja) when people go

\footnotetext{
197 This list consists of twelve books and their authors. Among them six are from the Mālikī School of Law; interestingly the famous book of Usman Dan Fodio on bid'a is also among them (see Fierro 1992: 207-209). Fierro also mentions that kutub al-bida was a widespread genre especially among the Mālikī writers (Fierro 1992: 210).

${ }^{198}$ Fierro mentions a few Mālikī Scholars from North Africa like Muhammad b. Sahnūn (d. 870), Ibn Abi Zayd al-Qayrawānī (d. 996), al-Qābisī (d. 1012), and al-Bàjīi (d. 1081) who wrote about the issue of "bid'a."
} 
to local mosques to celebrate it, festivals on the night of the $10^{\text {th }}$ of Muharram, and celebrating non-Islamic festivals. ${ }^{199}$

Prayers are the fourth field where innovation(s) occurs. Ibn Waddah criticized the practice of calling people to morning prayer through the sentence "prayers are better than sleeping" ${ }^{200}$ that follows the adhän (in Arabic: call for prayers). He and alTurtushi refused the raising of hands during $d u^{\prime} \bar{a}$ (in Arabic: invocation) since it is practiced by the Jews. Ibn Waddah also considers the use of a rosary to be bid'a.

The fifth point concerns the issue of funerals. Al-Turtushi advises that funerals should be short. He heavily rejected funeral ceremonies as - bid'a -, as well as reciting the Qur'ān at tombs or practicing tasbih. Other innovations condemned by alTurtushi and Ibn Waddah are related to food and clothes, the qusass (in Arabic: people telling their stories in mosques), and performing pilgrimage on behalf of someone else. On the basis of the works of these Muslim scholars Fierro concludes that the concept of bid'a is a dynamic concept in the history of Islam. Although many practices were defined as innovation and excluded from the Islamic canon, they persisted in being part of the Islamic history.

The concept of bid'a was also studied by Sheikh Usman dan Fodio (d. 1817) who is an Islamic authority for contemporary Nigerian Muslims regardless of their different affiliations (Sufis, Salafī, etc.). In his book ihyä' al-sunna wa-ikbmād al-bid'a (The revival of the sunna and the Extinguishing of Innovation), dan Fodio deals with innovation and its manifestations. As a definition, he agrees with the point of view of $A b \bar{u}$ al-Hasan al-Saghīr that bid'a is "what is outside the Book (Qur'ān), the sunna, and the consensus” (Dan Fodio, n.d.: 10). Dan Fodio, like many previous scholars, positioned innovation in opposition to the sunna. When it comes to the categories of innovation, dan Fodio spoke of the above five already-mentioned categories. He distinguishes a bid'a that can be denied and an innovation that cannot be denied: "... it is not allowed to you to deny (somebody's bid'a) until you know that it is among the forbidden ones (through consensus)" (Dan Fodio, n.d.: 15; translation RbA). In Usman dan Fodio's book, a dual argumentation can be observed from the beginning to the end of the text. Only in the first three chapters (out of 33 chapters) does he define what he understands as sunna and bid'a, while all the other chapters are constructed according to the following schema: first, a spediific theme is introduced and explained how it is understood in the context of sunna. Subsequently, innovation(s) related to that issue are listed and studied. For example, imann (faith) is evaluated in the context of sunna and then innovation(s) related to it are analyzed.

Thematically, the book can be divided into the following categories: issues on the relationship between God and human beings (imān: faith, invocation, etc.); issues related to 'ibādāt (worship) (prayer, ablution, pilgrimage, times of calls for prayer, etc.);

\footnotetext{
199 The practices considered here as innovations are not explained in details as the author did this article; Shabān is the eigth month in the Muslim calendar, Rajab is the seventh, Dhö-l-Hijja is the twelfth, and Mubarram is the first.

200 This practice has spread to many Islamic countries today.
} 
issues dealing with human transactions (selling of property, inheritance, etc); issues of human behavior (ways of eating or dressing, etc.); and, lastly, issues associated with specific knowledge (healing, vision, Sufism). All these themes are studied according to their position in the sunna and in relation to bid'a. ${ }^{201}$ The relationship between God and human beings as well as imān (faith) are addressed early in the book. Imann means for dan Fodio that "every believer should take his faith from the Qur'ān. All regulations of faith are to be found in the Qur'ān" (n.d.: 24). He further elaborates on this point, indicating that somebody's shahada (confession of faith) allows somebody to get married, lead people in prayers; have his slaughtered animals eaten by people, inherit and bestow inheritance, and be burried in Islamic cemeteries (Dan Fodio, n.d.: 28). Concerning the issue of bid'a in the same context, al-ta'assub fi-l-din (fanaticism in religion), corrupting a Muslim's faith, bringing common people to struggle, and "dark" philosophy are considered to be aspects forbidden as bid'a (Dan Fodio n.d.: 29). ${ }^{202}$ In the same category, a believer should only swear by Allah - as the Prophet did. The act of swearing implies that the believer should restrict him- or herself to that. Swearing by the Prophet or by the Ka'ba can be considered bid'a. Also, the practice of fasting for three days is taken into consideration. When somebody cannot remember what he has sworn, he should consequently free somebody, clothe ten poor people or feed them. According to Dan Fodio, this can also be considered a bid'a. Also fasting on Fridays or praying during the entire night of Friday falls under the category of bid'a (Dan Fodio n.d.: 119-121).

The second category is that of ibādāt (in Arabic: worship). Two examples - prayers and pilgrimage - will be discussed below. Performing prayers should follow the example of the Prophet. The famous hadith collectors al-Bukhārī (d. 870) and Abū Hurayra (d. 681) described the way the Prophet performed prayers as an ideal way to practice this religious duty. As for the issue of bid' $a$ in the context of prayers, the "adjustment of lines" (Arabic: taswiyat al-sufüf) 203 before prayers is considered a "disapproved innovation" (Arabic: bid'a makrüba). In addition, using sajjāda (in Arabic: a carpet for prayers) is considered bid'a. Dan Fodio's argument is that the pious predecessors preferred praying on the ground without any carpet or any other similar item whatsoever. It was known that some people used the so-called khumra (in Arabic: a small palm leaf used to place face and hands on during prayers) and this practice was rejected. It is preferred to pray on the ground, and if this is not possible,

\footnotetext{
201 The thematic categorization of the chapters allows us to give few examples of Dan Fodio's analysis of "bid'a." As there is no space to introduce and to discuss here the whole content of Dan Fodio's book, a few samples from each subject will be quoted.

${ }^{202}$ Dan Fodio did not explain what he maens by "dark" philosophy.

203 This is a duty of any Imām leading șalāt. He should look for taswiyat al-șufüf. The fact that Usman dan Fodio characterizes the practice of "adjustment of lines," which is in fact a widespread and undisputed practice in Muslim societies today, as a bid'a makrūha is due to the fact that Usman dan Fodio was not sure whether this practice was indeed introduced by the Prophet. This example shows that Usman dan Fodio really sticks to the Qur'ān and the Sunna of the Prophet and that he regards everything that is not covered by Qur'ān and Sunna as a bid'a.
} 
then on a thick mat (Arabic: hasìr ghaliz), on a thick linen (Arabic: kittān ghaliz), or on cotton (Arabic: qutn) (dan Fodio, n.d.: 58-70). ${ }^{204}$

As for the issue of pilgrimage, Dan Fodio emphasizes that everybody should perform hajj (in Arabic: pilgrimage) following the way the Prophet performed it. This way is described in the hadith tradition. What is considered bid'a shaytaninyy (in Arabic: Satanic innovation) is the practice of kissing al-hajar al-aswad (in Arabic: the Black Stone in the Ka'ba, in Mecca) or putting one's cheek and forehead on the stone. Touching the Ka'ba's wall or that of the Grand Mosque in Mecca is also considered innovation. In addition, having a special $d u^{\prime} a{ }^{\prime}$ (in Arabic: supplication) for a particular place during hajj (like $d u^{\prime} \bar{a} '$ in the Mosque in Mecca, another one for the mosque in Medina, particularly at the Black Stone) is also considered a bid'a. Furthermore, Dan Fodio rejects surrounding the tomb of the Prophet and touching it, condemning this practice as bid'a (dan Fodio n.d.: 107-110).

Among the categories of issues dealing with human transactions, only the issue of bay' (in Arabic: selling) is discussed. Dan Fodio indicates that facility (Arabic: subüla) and generosity (Arabic: samaha) but also not cheating are required for any transaction (buying, selling, or borrowing). Concerning bid' $a$ in the context of buying and selling, a person who is jabil (here: ignorant of the buying and selling rules, $\mathrm{RbA}$ ) is not allowed to practice this activity and respective activities would be considered an innovation. Also, the fact that men stay at home and women go to the market and compete with other men is also regarded as a bid'a. It is also bid'a when a woman goes out to buy something from a seller, or if she is alone with a seller in his shop. Dan Fodio adds that if a woman is obliged to go shopping in the market, it is allowed since there is no possibility of being alone with a man (dan Fodio n.d.: 125-130).

The next issue is human behavior. Dan Fodio describes regulations concerning clothing and eating. In the sunna of the Prophet, it is preferred that clothes are white, and not very long. Clothes made of silk are not allowed for men. Bid'a is when clothes are too large and long (which is recommended only for women). Also imitating nonMuslims in clothing is bid'a, but also when men imitate women. In addition to that, pride in one's clothes (Arabic: mubāhāt) is a form of bid'a. Sleeping without clothes is also bid'a. When a woman wears her best clothes and jewellery when going out in public, this is bid'a muharrama (in Arabic: forbidden innovation) (Dan Fodio, n.d.: 142-153). Concerning the issue of eating, only a few examples are mentioned. Sitting - and not leaning - when eating is sunna. Also giving food to people sitting on one's right side is sunna. However, making food for a particular person is bid'a, since food is to be shared. Eating with a spoon is bid'a and joking while eating is also bid'a (Dan Fodio, n.d.: 153-159). ${ }^{205}$

The last category of innovations is special knowledge like healing, visions, or Sufism. A few examples of bid'a related to healing and to Sufism are given here. In the sunna and among the methods of healing is the use of the Qur'ān. Honey is one rec-

204 The examples given here are only a sample from many issues related to prayers raised by dan Fodio.

${ }^{205}$ Only some examples are listed here and not all points reflected by Dan Fodio. 
ommended method. The use of kay (in Arabic: cautery by fire) as a remedy is rejected. What is considered bid'a is, for example, the use of trash or alcohol in the healing process. Also in the Mālikī School of Law, the use of foreign or incomprehensible languages or statements is forbidden. Moreover, any practice resembling magic is bid'a (dan Fodio, n.d.: 164-166). Sufism is covered in the last chapter of Usman dan Fodio's book. Any practice (binding oneself, cautery, etc.) leading to damage of oneself (Arabic: idbrār al-nafs) is under bid'a muharrama or forbidden innovation. Also, listening to singers is bid'a. Additionally, the so-called karāmāt al-awliyā (in Arabic: marvels of the saints) is a bid'a for those who claim it without proof or without going back to the Qur'ān, the sunna, and the tradition of al-salaf al-sălih (dan Fodio, n.d.: 170-175).

From this non-exhaustive discussion of the concept of innovation in Islamic history, it is clear that bid'a is a complex and multifaceted notion. From the definition of the term $b^{\prime}{ }^{\prime}$ ' $a$, the meaning varies between innovation in a positive and negative sense. The meaning of bid'a can change drastically from innovation and novelty to creativity and heresy. In many cases, bid'a is presented as an antithesis of the sunna. Some researchers think that bid'a does not mean kufr (see MacDonald 1913). For other scholars (see Robson 1960), the concept is misunderstood and has negative connotations for Muslims. In some contexts, bid'a is related to state administration - often related to taxes during the Ottoman administration (see İnalcak 1995). In other cases, it is related to heresy without being synonymous to it (see Lewis 1953). Innovation can be "good" or "bad." It can be considered an aspect of non-belief if it concerns faith and worship. 206

The expression bid'a thus has different forms and occurs differently. For these reasons, maybe it is better to use it in the plural: bida'. Historically, the concept goes back to the first century of Islam and was debated along with other terminology like mubdath (in Arabic: new). The famous categorization of bida classifies it into obligatory, recommended, illicit, blameable and licit, as we have seen above. This categorization is not the only one, however. Islamic authorities play a crucial role in defining innovation (see Talbi 1960). Bid'a can be political or ritualistic. By the time a sunna is revived, bid'a is uprooted (see Goldziher 1890/1971). Innovation can occur among individuals, between an individual and an institution, or between two institutions. Innovation can also be in a particular place (mosque) or time (Ramadan). It can touch on orthopraxy (prayers, funerals, recitation of the Qur'ān) or behavior (ways of dressing, eating, etc.) (see Fierro 1992). Innovation is dynamic and can be found in many fields of Islamic tradition. There are various examples of innovation(s) - as shown by dan Fodio. Bid'a is dynamic and changes from time to time depending on understanding(s), definition(s), and interpretation(s) provided Islamic scholars of a particular period. Lewis' statement can be used as a sort of conclusion since "a bid'a of today may become a sunna of tomorrow" (Lewis 1953: 52).

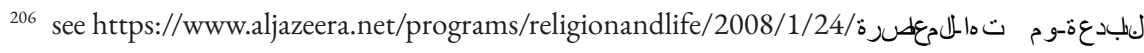


In the next section, I will study bid'a and its different meanings and connotations in the Nigerian context. I will introduce the approach of the Izala movement to bid'a and analyze the discourse between Izala movement and Sufis. The book of Usman dan Fodio was, thus, a good introduction to the next section since he is considered by the Izala movement to be a fighter and opponent of both bid'a and Sufism.

\subsubsection{The Izala discourse on bid'a}

When asked about the history of the Izala movement in Nigeria, the current Izala leader in Jos, Sheikh Sani Yahya Jingir, responded: "Sheikh Ismaila Idris tried to show people how some enemies of Islam practice some things in the name of religion and by doing that, (he showed how) they deviate from the path of the Prophet." ${ }^{207}$ The founder of the movement directed his criticism towards the Sufi brotherhoods. He belongs to the tradition of Sheikh Gumi, the initiator of anti-Sufi tendencies in Nigeria. The Izala movement sees itself as protector of the sunna of the Prophet and the fighter against innovations in the religion of Islam. The so-called salät al-fätib ${ }^{208}$ (a Tijāniyya prayer practice) was heavily criticized by Izala movement. The claim that reciting this prayer is 6,000 times better than the recitation of the Qur'àn raised a huge debate and heavy criticism from the Izala movement. This debate concerns a crucial element of the Izala movement worldview: the Qur'àn. The Holy book of Islam is the central source and the basis of the Islamic faith; it is also the basis for the tradition of the Prophet. The Izala movement doubts the credibility of this prayer, salāt al-fätỉh, and its origin. If this prayer was revealed only to Sufis, why is it mentioned neither in the Qur'ann nor in the sunna? This is the main argument of the Izala movement. And why do only members of the Tijāniyya (among all Muslims) know about it? Is it possible for certain Muslims to have something better or more valuable than the Qur'ān? Something that is 6,000 times better? These kinds of questions have been raised by the Izala movement concerning the "extra-prayers" recommended to the Tijāniyya and only to them. In a letter entitled "risāla ilā'l-ikhwān al-muslimīn fi'l-radd 'alā qawl alsheikh al-munharif 'an al-kitāb wa'l-sunna" (Letter to Muslim Brothers as an answer to the sheikh's deviations from the Qur'ān and sunna) written by Sheikh Ali Mustafa Abubakar Alburnawi, an Izala movement leader from Maiduguri, who was linked to the Kaduna faction of the Izala movement, the Sufis are criticized of pretending to have a hidden and unrevealed source in the Islamic tradition:

Allah - glorious and exalted is $\mathrm{He}$ - did not order us to follow what has not been introduced through the Prophet Muhammad - peace be upon Him. Sufi Brotherhoods: Tijāniyya, Qādiriyya, Shādhiliyya, Rifāciyya, Hurūriyya, Ahmadiyya, and others - you can't find a concrete indication (amran dha-

\footnotetext{
207 Interview with Sheikh Sani Yahya Jingir, Izala Jos leader, Jos, 28 January 2007.

${ }^{208}$ Abun-Nasr (1965: 51) mentions that this prayer "came from heaven to the Sufi Sheikh Muhammad al-Bakri (1492-1545) and Sheikh Tijānī was told about it through the Prophet.”
} 
biran) related to them in the Qur'ān, in the hadith of His Prophet - PBUH -, or in the sources of the sabāba (campanions). These turuq (Brotherhoods) are a sum of interpretations of some Qur'ānic verses and weak hadìth. So don't cheat yourself so that you lose your knowledge through total following of saints and Sheiks in erratum (khatac) and correctness (sawab), in what is admissible (haläl) and what is forbidden (barām), in guidance (buda) and aberration (dhaläl), and in non-belief (kufr) and conviction (imän) (Alburnawi 1990: 5-6). ${ }^{209}$

The author doubts that Sufism has its origin in Islamic tradition and criticises the misguidance of Sufi sheikhs vis-à-vis their followers. His argument in the entire booklet is that there is no mention of saints (Sheikh al-Tijānī or Sheikh 'Abd al-Qādir alJìlānī) in the Qur'ān. Also in the hadìth, neither Sufi leader is mentioned. The leader of the Izala movement condemns Sufi practices as such litanies, and indicates that no one among the șậăba and the four Imams (Mālik, Abū Hanīfa, Ibn Hanbal, and alShāfíi) have heard about it (Alburnawi 1990: 7-8). He adds that it is a bid'a to claim "prophecy" through receiving something more valuable than the Qur'ān (Alburnawi 1990: 10). Alburnawi opposes the claim that Sheikh al-Tijāni belonged to the family of the Prophet or that any silsila (in Arabic: chain) - confirming that - ever existed in Islamic history (Alburnawi 1990: 14-15). ${ }^{210}$

If there is something that has been criticized even more by the Izala movement, it was the celebration of the mawlid (in Arabic: birthday of the Prophet). The Izala movement draws attention to the fact that neither the Prophet himself nor his companions celebrated this event. That is why this celebration feeds into the category of bid'a. Ustaz Nuhu Tahir Tajudden at the Centre for Islamic Development in Zaria and linked to Izala movement Jos, indicates that mawlid was rejected by the Izala movement and categorizes it as a small bid'a within the larger system of Sufism: "Mawlid was among the things they do and that we criticize, but we consider it a small bid'a (innovation), smaller than Sufism itself, (it is) the smallest bid'a." 211

The Izala movement does not recognize any statement or practice which is not mentioned in the Qur'ān, the sunna, or the tradition of the pious predecessors. The Izala movement presents itself as the "guardian" of the sunna. Anything that is seen to be outside this claim is categorized as an innovation. The Izala movement's understanding of bid' $a$ in fact conceives bid' $a$ to form the opposite of the sunna - as presented by MacDonald (1913). Beyond that, Sufism is considered an aspect of non-

\footnotetext{
209 Alburnawi indicates in this letter that it is an answer to Gonimi "who deviated from the "path of truth" (...) and who wrote strange things that nobody in Maiduguri understood the content and he distributed it among the 'ulamā' and the zawāya" (corners; usually areas surrounding Sufi tombs) (Alburnawi 1990: 4).

${ }^{210}$ Alburnawi raises the question here as to how Sheikh Tijānī can be related to the Prophet? He criticizes the "salasil" (chains) made by Sufis to reach the Prophet or his family. ${ }^{211}$ Interview with Ustaz Nuhu Tahir Tajudden, Centre of Islamic Development, Zaria, 10 January 2007.
} 
belief - as presented in the context of heresy by Lewis (1953). The Kaduna-faction of Izala avoids declaration of non-belief (takfir) towards other Muslims. ${ }^{212}$

The late Sheikh Ja far Mahmud Adam of Kano summarized the following points of criticism from the Izala movement towards Sufis and Sufism: unity of universe, incarnation, practicing dhikr or amulets. According to him, Sufism has ways of thinking that are common to most Sufi brotherhoods as expressed in the concepts of 'wahdat al-wujūd' (the unity of universe) and 'aqīdat al-hulūl' (infusion of substance, incarnation), which means the incarnation of human beings in God and God in the human being. These ideas have been massively opposed by the Izala movement. Also, the issues of 'dhikr jamā' î' (collective remembering of God) and the reciting of 'adhkār' (pl. of dhikr, $\mathrm{RbA}$ ) in congregation have been rejected by the Izala movement according to Sheikh Jaffar Mahmud Adam. The same is true for 'tamāim' (amulets) and 'ta 'widh' (exorcism) with the motive of protection from 'al-ayn' (the evil eye) and from alshayțān (Satan). Also, some formula of praising the Prophet Muhammad that are not covered by the sunna are condemned by the Izala movement. ${ }^{213}$

The ex-Izala member and JNI-murshid (in Arabic: advisor) in Jos, Abdurrahman Lawal Adam, listed eight points on the issue of bid' $a$ that have been condemned by the Izala movement and especially by Sheikh Idris during his lifetime. First, the mawlid is considered something "new" which was not celebrated during the time of the Prophet or by his disciples after the Prophet's death. Second, the book of jawāhir al-máāin and the prayer șalāt al-fätiḩ were rejected by Sheikh Idris. Third, Sheikh Idris also criticized the practice of jawharat al-Kamäl by Tijānis and also the use of the word saqam (in Arabic: seek) to qualify the Prophet. Fourth, practicing dhikr, waziffa (Friday, after afternoon prayers) during which the Prophet appears, were rejected by the Izala movement founder and his followers. Fifth, the giving of șadaqa (in Arabic: voluntary alms) after someone's death and that people come after the $3^{\text {rd }}, 7^{\text {th }}$ or $40^{\text {th }}$ day after someone died in order to supplicate Allah is also considered to be a bid'a. Sixth, the tradition of läzim (in Arabic: binding; obligatory custom) that is especially practiced by the Tijāniyya brotherhood and that consists of reciting verses in praise of the Prophet or tasbih (in Arabic: glorification of God) every day for 100 or 1000 times is a bid'a. Seventh, the awräd (in Arabic: special prayers in the Sufi ritual) that were supposedly recommended by the Prophet for the followers of the Tijāniyya) are a bid'a. Finally, the so-called tradition of al-qubüriyya (from Arabic: qabr: tomb; visiting tombs). ${ }^{214}$

\footnotetext{
${ }^{212}$ During an interview with Sheikh Alhassan Said in Jos, he mentioned that the Kaduna faction of the Izala movement do not go so far as to declare Sufis "kuffar" (non-believers) - as the Izala movement Jos faction does (Interview 12 December 2006). This information was confirmed by Sheikh Abubakar Mujahid, leader of the Tajdid-group on 5 January 2007 in Zaria.

${ }^{213}$ Interview, 2 January 2007. The late Sheikh Ja'far can be considered part of the Salafiyya movement in northern Nigeria.

${ }^{214}$ Interview 27 December 2006; for more details on the issue of "bid'a" see also Lawal Adam (1992: 132-155).
} 
Again, we see that most issues criticized by the Izala movement and considered bid' $a$ belong to the category of orthopraxy, and only a few examples relate to 'aqida. The Izala movement condemns issues related to 'ibādāt and demands that their origin be proven. The organization raises the point as to why Tijānīs practice certain litanies and prayers that are not known to the rest of the Muslim community. The Izala movement doubts the source of these prayers and could not find any evidence of these practices in the sunna. Yandaki mentions that Izala movement condemned Sufi concepts as "blameworthy innovations" (Yandaki 1990: 133). These concepts are related to sainthood, intuitive knowledge, mediumship to spirits or to God, control of jinn, etc. Also, practices like dhikr, the use of drums in mosques, is condemned. Yandaki proposes another category of innovations criticized by the Izala movement: those related to the Hausa culture and seen as un-Islamic; and those related to marriage, birth, and naming ceremonies or death (burial ceremonies) (Yandaki 1990: 133-134).

The national secretary of the Izala movement, Bashiru Makama, from the Kaduna faction of the Izala movement, raises a basic point of criticism against Sufism. He explains that recognizing tariqa and its practices as something revealed by God means opposing what occurred in the Qur'ann- that the Prophet Muhammad is the seal of all Prophets and his message is the last one addressed to mankind:

All these turuq or Sufi Schools are not organized in a proper way. Why? This Islamic religion was revealed to Muhammad - șallā Allabu alaybi wa sallam and Allah - subbanabu wa ta'äla - it is stated in the holy Qur'ān that Muhammad is the final messenger of Allah and after him (the messenger) there is no more revelation to anybody. ${ }^{215}$

This movement denies any type of "divine" character of Sufi practices with the argument that it was not mentioned in the basic sources of Islam (Qur'ān and sunna). Interestingly, Sufi brotherhoods counter with the same argument. They also accuse the Izala movement of practicing bid'a. Sheikh Tijani Ibrahim from Kano points out that the expression Abl al-Sunna (in Arabic: people of the sunna) does not occur in the Qur'ān and it was not mentioned by the Prophet himself. He questions, astonished: "Is that not bid'a?" 216 His position demonstrates again the problem of definition of the concept and the issue of authority. Who has the right to define the concept? How can it be rightfully understood? How can it be used correctly?

Sheikh Ibrahim Saleh al-Husseini, the Tijāniyya leader from Maiduguri, dedicates a chapter (chapter 33) of his book al-Mughir (1986) ${ }^{217}$ to the issue of bid'a introduced according to him - by Izala movement. The Sufi sheikh criticizes the fact that the new "sect" (Izala movement) declared other Muslims "non-believers" and abandoned the mosques to establish their own. According to him, this is a deviation from the path of

215 Interview in Zaria, 9 January 2007.

${ }^{216}$ Interview with Sheikh Tijani Ibrahim in Kano, 3 January 2007.

${ }^{217}$ Here, I am using the second edition (2003) of Almaktaba Al-Ibrahimiyya publications. 
Abl al-Sunna and the Mālikī School of Law. Sheikh Ibrahim Saleh provides evidence that establishing a new Friday-mosque has particular regulations. The 'ulamä' defined certain extenuating circumstances under which two Sunni groups can establish a new mosque. If the conflict is between a Sunni group and what he calls $A b l$ al-Abwa (people of the passion; Izala movement in this case), then they should be banned from performing the Friday prayer: "If there is a struggle between Ahl al-Ahwà and Ahl alSunna, then it shouldn't be taken into consideration. The judgment for Ahl al-Ahwā is that they should be banned from performing the "jumu'a prayer" - they should even be banned from anything allowing them to spread their innovations (bidac) and aberration (dhaläl) (al-Husseini 2003: 395). ${ }^{218}$

Sheikh Ibrahim Saleh indicates that a meeting was held by a committee of Islamic scholars to discuss the issue and came to the result that the Mālikī School of law does not allow a new mosque if there is no need for it. There are cases, however, when the mosque may be too small and cannot be extended or where two Sunni groups are at odds. Other possibilities to sove this dilemma are given, when one group bans the other from praying in the mosque and fights them when they come for prayer, or if there is a ruler banning both groups from fighting, or, finally, if there is a distance of three miles between the two communities (al-Husseini 2003: 398). The Sufi sheikh concludes that none of these requirements are given and adds that the committee agreed that such a step led to the division of the Islamic umma. Furthermore, he sees the call to build a new mosque as bid' $a$ and deviation from Abl al-Sunna since the "innovator" (Arabic: mubtadic) is someone who believes in something different from the (path of) Abl al-Sunna (al-Husseini 2003: 400-401). ${ }^{219}$

Even before the establishment of Izala movement as an organized institution, Sheikh Idris, the founder, criticized Sufis and Sufism. He distinguished between a small bid'a that deal with practices (naming ceremonies, marriage, etc) and "major" or "serious" ones that corrupt faith (imann). This second type is more dangerous: "He [Sheikh Idris] started discussing issues of bid'a like the practicing of the naming ceremony, regarding the institution of marriage and social activities of Muslims in general. Let's put it that way. This is one sight of the bid'a. Then the second sight of the bid'a comes to a major bid'a that can corrupt faith (imān). He called it a major and a serious one."220

Sheikh Idris went beyond bid'a by classifying Sufi practices as "non-Islamic" and as a "polytheistic performance". He concluded that praying behind Sufis during group prayers or getting married to their daughters "is not accepted, not correct, and not

\footnotetext{
${ }^{218}$ Sheikh Ibrahim Saleh al-Husseini indicates that in May 1984 the Izala sent a letter to the High Council of Islamic Affairs in Borno asking for a permit to establish his own Friday-mosque in Potiskum as well as his own abattoir.

${ }^{219}$ Chapter 34 of the book also discusses bukm (regulation) of establishing two Jumu'a mosques in the same town. Islamic Scholars of the Committee agreed that Izala movement should not be allowed to establish its own mosque.

${ }^{220}$ Interview in Jos with Mallam Sani Modibbo, 28 February 2007.
} 
valid.”221 The Izala movement founder regards such innovations as leading to hell. His interpretation of the famous hadìth kullu bid'a dhaläla wa kullu dhaläla fín-när (all innovation goes astray, which leads to hell) is that "kullu" means in Arabic "all" (grammatically it is known as "kullu al-kulliyya") without exception. Based on this understanding, Sufism is categorized under kufr and all innovations will lead believers to hell. Some followers of the movement looked for a confirmation of such an approach regarding the concept of innovation. Renowned scholars from outside the Izala movement were asked for more clarification on bid'a and on the meaning of the mentioned hadith. ${ }^{222}$ Interestingly, a new category of bid'a was added:

Then there is Sheikh Abū Bakar al-Jazāinī who was also delivering lectures at the mosque, on Medina premises, and between Maghreb and Ishä. We went and asked him a question on bid'a to explain what the meaning of kullu kulliyyin is? Kullu bid'a dhaläla. Sheikh Idris then cited that there are certain bid'a, which are unwanted but are compulsory. He gave one example: circumambulation on the top of the Kaba. When we go there, there are stairs leading to a walkway for circumambulation above the Ka $\mathrm{b}$. The Prophet did not perform circumambulation in this way ... he performed it only on the ground floor. There are those who refused to perform it this way...; this is one of the controversies we raised there. We went to him to ask a question: Are there those who say: "whoever performs the circumambulation at the top is not accepted because it is a bid'a? So we raised such questions. ${ }^{223}$

This example shows how the issue of innovation is debated not only among Izala and Sufis/non-Izala, but inside the Izala movement itself, especially during the initial stages of its development. The issue of bid'a not only drove a wedge between the 'ulam $\bar{a}$ ', but also among the followers who started questioning the correctness and basis of such a concept. During and after the division of the Izala movement, the issue turned out to be a matter of trust between those who trusted Sheikh Idris and followed him in all directions and those who doubted his fatwās and deviated from his path.

In conclusion, the matter of bid' $a$ is a central concept used by the Izala movement. The meaning of the word has been widely debated among the Islamic 'ulamä. Having the concept as part of the name of the organization summarizes its aim: "fighting

${ }^{221}$ Interview in Jos with Mallam Sani Modibbo, 28 February 2007.

222 Izala movement members used the opportunity of the Hajj in Mecca to clarify the meaning of "bid'a" as given by Sheikh Idris and inquired with Islamic scholars for more clarification. Sani Modibbo (and few Izala movement followers), (interview 28 February 2007) also used the example of the hajj to ask scholars like Sheikh Umar al-Fulati (Imām in Mecca) and Abdelqadir al-Jazairi (Imām al-Medina). ${ }^{223}$ Interview 28 February 2007. Another example raised by the Izala followers here is the issue of paying taxes to the Saudi state through hujjaji (pilgrims) and if it is bid'a or not. They received the answer that there are some innovations that are necessary and others that are forbidden. Concerning the meaning of kullu in the mentioned badith: "So there are certain bid'a which are not kullu kulli, but kullu Jozi. "Kollu Jozi". The Prophet said "kullu" but not all. It is not general. 
bid'a'. In the absence of a clear definition and the limitations of the concept, Izala followers have nothing but to rely on their leaders' views. Bid'a as defined by Islamic scholars of the Izala movement is basically directed at the practices of Sufis (dancing, prayers, celebrating mawlid, burial ceremonies, etc.) and asks for the relevance of their sources. The Izala movement sees itself as having access to relevant sources and at the same time controlling any deviation from the Qur'ān and the sunna. Bid'a is an open system of meaning. Sometimes, it is used in a negative way; and sometimes, it has positive connotation(s), as shown above. The categorization of the concept depends on the perspective from which it is understood. In most cases, dealing with the concept is subjective and if a Sufi is an innovator from the perspective of a follower of the Izala movement, then a follower of Izala movement can also be considered an innovator from the perspective of a Sufi. Within the Izala movement itself, views on innovation are different - especially for those who left the movement to study abroad or who joined another movement, or those who simply left. After the division of the Izala movement, it became evident that meanings are more related to personalities than to any other thing. The Josawa (Jos faction) are more fixed on the views of Sheikh Idris while the Kadunawa (Kaduna faction) invoke different interpretations. The limits of using the concept are also limitless. Every Muslim can interpret a particular practice as bid' $a$ and can blame another Muslim for deviating from the "right path" of Islam. During a discussion in Kano, I once heard a Sufi saying, astonished: "Did Muslims have loudspeakers during the time of the Prophet? If Izala movement now uses them, can't we also speak of a bid'a?"

There is no doubt that the issue of innovation is still central for the Izala movement, but during and after the split of the movement into two major groups, the concept was more related to leaders in particular. Innovation was used in the inner-Izala conflict to develop a new definition of bid'a - among other concepts. ${ }^{224}$ From a politico-psychological point of view, Jerrold M. Post's analysis - although in dealing with a different context of follower-leader relationships- reflects on this point (Post 1986: 675-688). The author speaks of a "mirror-hungry" personality and "ideal-hungry" followers. In the first category, the charismatic personalities "convey a sense of conviction and certainty to those who are consumed by doubt and uncertainty" (Post 1986: 680):

Ideal-hungry people can experience themselves as worthwhile only so long as they can relate to individuals whom they can admire for their prestige, power, beauty, intelligence, or moral stature. They forever search for such idealized figures (Post 1986: 679).

\footnotetext{
${ }^{224}$ See chapter 4.5. on the division and the debate between Izala movement Jos and Kaduna. Many concepts here are newly defined and directed towards the political dispute in the movement. The whole conflict was between those following Sheikh Idris and those who were against him.
} 
The issue on bid'a can be understood through this approach. In other words, Izala followers obtained their understanding of the concept from the guidance of their leaders. Even after the death of Sheikh Idris, the debate continued amongst those defending the founder and those who separated. The leader is the source of orientation in most religious organizations. He has the access to the Islamic sources and has the potential to guide followers in a "right way." The issue of innovation became a personal issue and overshadowed a theological debate. The whole discussion became an approval and disapproval of Sheikh Idris' views on the concept. This development is common especially when it comes to successions in religious organizations. The identification with the founder and with Jos as reference is still symbolic today.

\subsection{The Izala movement and Wahhābism}

Often, the Izala movement is seen as being part of or connected to the Wahhābiyya, not only amongst Nigerian Muslims (esp. Sufis) but also by observers outside West Africa. There are different connotations of the Izala movement. The movement is considered by some to be among the Abl al-Sunna wa'l-Jamāa (in Arabic: people of the sunna and the Community). Some people labelled it as Wabhäbiyya and link it to the Wahhābi movement that originated in Saudi Arabia, and others consider it to be a Salafiyya movement. This section serves as a clarification of Abl al-Sunna, Salafiyya, and Wahhābism and especially where to place the Izala movement.

The prominent Nigerian Tijānī scholar, Sheikh Ibrahim Saleh al-Husseini, warns in another book (2005) about a group of innovators (in Arabic: mubtadi'a) who sometimes claim to be Abl al-Sunna wa'l-Jamāa and sometimes on the path of al-salaf alsălih, although they are neither in reality. In fact, this category of people belongs to madhbab al-mushabaha and can be considered neither among Abl al-Sunna nor alsalaf al-sălih. Sheikh Ibrahim Saleh clarifies the existence of three different directions when it comes to understanding the concept of madhbab (in Arabic: school of law or jurisprudence). He calls the first category madbhab abl al-ta'till, or those scholars who use their reasoning and, by doing so, deviate in their interpretation from the scripture (Qur'ān) - for example, the so-called Jabmiyya and Mu'tazila, among others. ${ }^{225}$ The second group of scholars is known under the term of al-mushäbaba due to the fact that they used - in their discussion of the attributes of Allah - comparisons with His creatures, and thus fell prey to an anthropomorphic representation of God. When it came to the explanation of their faith, they showed confusion, however. The third and last category is abl al-sunna wa'l-jamā'a. This madhbab believes that anything related to the Prophet (Qur'ān and sunna) is "absolute" (Arabic: qat $\bar{\imath}$ ) or "rightful" (Arabic: sabịh). This should be confirmed by trustworthy scholars. Any issue categorized as

${ }^{225}$ Al-Jahmiyya was named after Jahm Ibn Ṣafwān (d. 745); al-Mu'tazila is an Islamic school of thought which emerged between the $8^{\text {th }}$ and $10^{\text {th }}$ centuries $(\mathrm{CE})$; both orientations were controversial among Muslims and were known for using reasoning to define the nature of God. 
mutashäbih (in Arabic: ambiguous) is only known by Allah. Scholars interpret it only in case of necessity, unlike the appearance of "innovators" who can influence people's faith (al-Husseini 2005: 18-19).226

The scholar and $d \bar{a} i$ (in Arabic: the one who practices da'wa; preacher, "missionary") Ahmad Bello Dogarawa does not see much difference between abl al-salaf, abl al-sunna, or abl al-hadith. According to him, after the death of the fourth "Rightfully Guided” Caliph 'Uthmān Ibn 'Affān (d. 656), the Islamic umma witnessed the appearance of different Islamic groups like the "Qadariyya" and the "Mu'tazila" as a result of the Kharijites. Some Muslims saw this as innovation in din (in Arabic: religion). He elaborates his argument by dividing the Islamic umma into two major groups: the Shī' ites and abl al-sunna (Sunni Muslims). He categorizes abl al-sunna in al-Marjicyya, Kharijites, al-Mu'tazila, and the abl al-hadith wal-Athar.

The debate was raised concerning belief in the Qur'ān and the sunna of the Prophet. Especially during the time of Ahmad Ibn Hanbal (d. 855, CE), the community was "divided" between those who followed Ablal-Sunna and those who did not. The Salafiyyün believe in the Qur'ān, the sunna, al-șahāba (the Companions), al-Tabi ün (the followers), and Tabi ${ }^{i}$ al-Tabi in (the followers of the followers) - in general the first three generations of the Muslim community. Concerning Abl al-Sunna, there is no substantial difference. Both Salafiyyūn and Abl al-Sunna agree on matters of tawhìd (oneness of God) and 'ibädat of al-salaf al-sālih. ${ }^{227}$

Ustaz Umar Adamu Muhammad (al-Hafiz), an imām and scholar of Arabic, constructs a link between Izala movement and Wahhābiyya as a movement. According to him, Muhammad Ibn 'Abd al-Wahhāb denied anything outside of Islam - a point of view which is similar to Izala movement. In addition, Izala movement uses the book of Ibn 'Abd al-Wahhāb, although they (the Izala movement) do not call themselves Wahhābbis. Interestingly, he points out that Sufis call anything coming from Saudi Arabia "Wahhābī." Since Sheikh Gumi, the spiritual father of Izala movement, was linked to Saudi Arabia, the Izala movement is thus "connected" to Wahhābism in many cases. ${ }^{228}$

The Islamic scholar and student of Sheikh Gumi, Sheikh Muhammad Sanusi Gombe categorizes Nigerian Muslims as Mālikīs following al-áqìda al-ash'ariyya. Apart from the Sokoto Caliphate and the call of Usman dan Fodio to the sunna, Sheikh Sanusi Gombe considers the call of Sheikh Abubakar Gumi to be awwalu da'wa 'alā tariqa abl al-sunna wa'l-jamāa (the first call to people following the path of $\mathrm{Abl}$ alSunna) in modern Nigeria. According to him, Sheikh Gumi preached to people following the path of Salafiyya - al-aqida al-Salafiyya.

\footnotetext{
226 I have tried to summarize the explanation given by the author in his Arabic text. The author elaborates more on the third category and narrates several sources agreeing that Abl al-Sunna is basically comprised of the four Schools of Law (Mālikī, Shāfi īi, Hanbalī and Hanafī).

227 Interview with Ustaz Ahmad Bello Dogarawa in Zaria, 8 January 2007.

228 Interview with Dr. Umar Adamu Muhammad, 18 January 2007, Kaduna.
} 
When it comes to the Izala movement in Nigeria, Sheikh Sanusi Gombe mentions that the organization was established on the basis of al-salaf al-săliḥ. Furthermore, Sheikh Sanusi Gombe finds a connection between the Izala movement and the Wahhäbiyyamovement, especially in their methods. He argues that both the Izala movement and the Wahhābiyya are against visiting tombs and istighätha (in Arabic: supplication; relying on an intermediary between creator and creature). He adds that the Izala movement teaches the books by Muhammad b. 'Abd al-Wahhāb. The interviewee differentiates between the Izala movement and the Wahhäbiyya-movement in the following: "The Wahhābis have nothing to do with this life, but Izala do. The Wahhābī consider leadership [the Sheikh is the leader], but in Izala everyone considers himself a leader."229

Sheikh Sanusi Gombe further elaborates in his argument that the Tijāniyya and the Qàdiriyya brotherhoods in Nigeria are also among Abl al-Sunna, following the Qur'ān and the sunna of the Prophet. Although the two are older than the Wahhābiyya, they were attacked by the Wahhābiyya-movement. He gives an example from Sudan where the Mahdī Muhammad Ahmad opposed the Tijāniyya and the Qādiriyya. At the same time, the Tijāniyya opposed the Qãdiriyya and al-Mahdī, etc. He concludes that the Wahhābiyya "cleansed" (Arabic: masahat) any type of Sufi-Brotherhood. ${ }^{230}$

According to the Izala leader in Lagos (linked to the Jos faction), Dalha Abubakar Abdallah, every contemporary Salafiyya-follower was associated with the Izala movement before. He cannot see a big difference between the Izala movement and the Salafiyya movement. He is surprised to identify a Salafiyya outside of the Izala movement:

As you know and as I told you, the people of Nigeria like leadership. Everybody who belongs to Salafiyya now was an Izala before. He wants to have a specific name different from the Izala movement and he calls his followers to recognize him as a leader. I don't know how we can differentiate between the Izala movement and the Salafiyya. There is only a Salafiyya muassira (modern Salafiyya) that deviates from renowned 'ulam $\bar{a}$ ' and denied the Salafí- 'ulama'. This is what they do, and it is a mistake. They take from a famous 'alim and leave all that comes from Salafī- 'ulamä. People who call for Salafiyya doctrines don't like to belong to any of the four schools of law. They think that they are able do deal with law without the opinion of old and new 'ulamä. These people call for the Salafiyya-doctrines. ${ }^{231}$

One can understand from this statement that the Izala leader regards the Salafiyyamovement in Nigeria to be a kind of deviation from the Izala movement. He criticizes the fact that the current Salafiyya establishes itself in a tradition outside of the four Schools of Law. He mentions the examples of late Sheikh Jaafar Mahmud Adam, the

\footnotetext{
${ }^{229}$ Interview with Sheikh Sanusi Gombe, 17 January 2007, Kaduna.

${ }^{230}$ Interview with Sheikh Sanusi Gombe, 17 January 2007, Kaduna.

${ }^{231}$ Interview with the Leader of Izala, Dalha Abubakar Abdallah in Lagos, 18 February 2007.
} 
Kano Salafiyya scholar, who was with the Izala movement - according to the Izala leader in Lagos - and then travelled to Medina (Saudi Arabia) to study; and when he came back, he established the Salafiyya movement.

When asked about the doctrine of the Salafiyya in Nigeria and whether they are following the path of al-salaf al-sălih, Mallam Dalha Abubakar Abdallah mentioned that the movement [Salafiyya] follows only what is in conformity with its own standpoints and rejects all that is not. He adds that they claim to belong to the tradition of Sheikh al-Albānī (d. 1999), a controversial Islamic Scholar from Albania who taught hadith at the Islamic University in Medina and who belonged to the Salafiyya movement. He gives the example that al-Albānī accepted three types of taslìma (in Arabic: closing prayers), but the Salafiyya denied them. He also mentions the example of jinnPossession and the communication with jinn, which was rejected by al-Albānī, but not by the Salafiyya. ${ }^{232}$

Concerning the issue of Wahhābism and whether the Izala movement was influenced by the movement, Mallam Dalha confirms that the Izala movement reads and teaches the books of Muhammad Ibn 'Abd al-Wahhāb especially when it comes to the issue of tawhid. He mentions the title of the book fath al-majid written by Ibn 'Abd al-Wahhāb that is used by Izala movement in the context of the oneness of God. For this reason, Sufis call Izala movement "Wahhābiyya". He adds that Izala movement uses books by Ibn al-Qayyim (d. 1350) and Ibn Taymiyya (d. 1328), but he makes it clear that, "we agree with every book that attests to the oneness of Allah."233

The caliph of the Qàdiriyya-Nasiriyya in Kano, Sheikh Qaribullah Nasiru Kabara, avoids using the word "Izala" at all. He compares the relationship between the Sufi brotherhoods themselves and between Sufis and Wahhābiyya as "totally different." The Sheikh confirms that Sufism is older than Wahhābiyya. He observed what he called "alțāifa al-Wahhābiyya” (the Wahhābī-Sect) in Nigeria develop during the post-colonial time after it garnered support from politicians. Without mentioning the name of the leader of the Wahhābiyya [i.e. Sheikh A. Gumi], he describes how he was close to the Sardauna and Prime Minister Ahmadu Bello. Declaring the existence of Wahhābism implicitly or explicitly was not easy at that time since Dan Fodio was a Qãdirī and the Sardauna himself. After the assassination of the Premier of the northern Region of Nigeria in 1966, a big change happened since the leader of the "Wahhābis" declared that Sufis are practicing shirk. Since then, a kind of struggle between the Sufis and the Wahhabbis has taken place. Sheikh Qaribullah is convinced that the Sufi brotherhoods resisted and succeeded in stopping Wahhābism. This is confirmed - according to him - by the fact that Sufis today represent the majority of Muslims in the West African country. ${ }^{234}$

\footnotetext{
${ }^{232}$ Interview with the Leader of Izala, Dalha Abubakar Abdallah in Lagos, 18 February 2007.

${ }^{233}$ Interview with the Leader of Izala, Dalha Abubakar Abdallah in Lagos, 18 February 2007.

${ }^{234}$ Interview in the House of the Qādiriyya in Kano with Sheikh Qaribullah Nasiru Kabara, 2 January 2007.
} 
Although Sheikh Qaribullah relates the issue of shirk and takfir (in Arabic: declaring non-belief) to the rise of the "Wahhābī sect" in Nigeria, he shows in a chapter of his "al-Mir'āt al-șāfiya fi bayāni hạqīqat al-tașawwuf wa-ba'di rijālihi dhawi al-maqāmāt al-aliya" (in Arabic: The Clean Mirror in the Truth of Sufism and some of his highlyranked Representatives) that Ibn 'Abd al-Wahhāb stood against takfìr of Muslims. Sheikh Qaribullah warned that declaring Muslims as "non-believers" is associated with incorrect interpretations of the Qur'ān and the sunna. After listing a number of Islamic scholars like Ibn Hanbal and Imām al-Ghazālī - to mention a few - who rejected takfïr, Sheikh Qaribullah quotes the book "al-taḥdir min al-mujāzafa bi'ltakfīr" (in Arabic: Warning of the Risk of "Takfīr”) by Muhammad Ibn 'Alāwī alMālikī al-Husnī who explains his point of view of Ibn 'Abd al-Wahhāb: "Ibn 'Abd al-Wahhāb - God bless him - has a negative attitude towards takfïr, especially when it is related to him in declaring kufr by those who opposed him and his ideas. This is Ibn 'Abd al-Wahhāb denying all that was related to him among these lies and claims (...). ${ }^{2} 235$

On the first page of the journal al-Burbān (the Proof) edited by the Izala movement headquarters in Jos, we read the sentence "al-aqiida al-salafiyya khayr min alshahāda al-'ilmiyya" (in Arabic: "the Salafiyya path is better than any academic certificate"). The Izala movement itself insists on its original name and it neither accepts nor denies other connotations like "Salafiyya" or "Wahhābiyya". The Sokoto-based historian Yandaki interprets the relationship of the Izala movement and Salafiyya and the relationship of the Izala movement and Wahhābism as follows: Salafism goes back to the first three generations of Islam. Salafism in general is opposed to Sufism. The Hanbali School of Law is especially clear on this issue. The famous Islamic scholar Ibn Taymiyya (1263-1328 CE), a Hanbalī himself, rejected Sufism and regarded it as "corrupting the teachings of al-salaf al-șalih."” Ibn Taymiyya rejected the visiting of tombs in order to obtain baraka (in Arabic: blessing). He refuses the idea of tawassul (in Arabic: continuity, intercession) in Sufism and understands it as a form of shirk. Yandaki observes similarities between this attitude and the attitude of Izala movement in rejecting Sufism and their practices (Yandaki 1990: 86-90). When it comes to Wahhābism, Yandaki sees it as an external factor in the rise of the movement. He traced the roots of the Izala movement back to the Saudi-dominated Muslim World League (Räbitat al-älam al-Islämì): "The Izalatul Bid'ah movement is directly influenced by the Saudi based Rābița. In short, Izala is the result of the outreach of the Rābita”" (Yandaki 1990: 101).

Yandaki explains that Wahhābism is behind the Muslim World League and concludes that Izala movement is indirectly influenced by the movement. Yandaki explains that Ibn 'Abd al-Wahhāb after whom the Wahhābiyya is named, led a "puritanical" movement that opposed Sufism and all other innovations in Islam. Yandaki adds that the books of Ibn 'Abd al-Wahhāb touch on problems of 'aqìda and concentrate on the

\footnotetext{
235 See Qaribullah Nasiru Kabara (n.d.): al-Mir'ät al-șāfiya fi-bayāni haqīqat al-tașawwuf wa ba'di rijālibi dhawi al-maqāmāt al-áliya.
} 
issue of tawhìd. The historian sees Wahhābism as a common phenomenon in Africa from east to west and in the north of the continent. Especially in West Africa, he relies on the PhD-Thesis of Lansiné Kaba to explain the spread of Wahhābism. According to Kaba, the spread of Wahhābism can be explained by four factors: pilgrimage to Mecca, trade, nationalism and the rise of revivalism (Yandaki 1990: 106-107). ${ }^{236}$ During the 1930s in particular, Wahhābism took root in the Ivory Coast before it reached Mali, Niger, and some other countries in the region. The coming of Wahhābī ideas to Nigeria is similar to their spread in other West African countries. Students who studied abroad in Egypt, Sudan and Saudi Arabia contributed to the coming of Wahhābism. A comparable situation was created by teachers and lecturers originating from these countries. They heavily influenced the religious landscape of West Africa. Yandaki mentions Sheikh Gumi as a prominent example (Yandaki 1990: 106-107).

The late Sheikh Ja'far Mahmud Adam of Kano, who underwent a transformation from a member of the Izala movement to a Salafì scholar after he studied in Medina, remarks that both factions of the Izala movement in Jos and Kaduna as well those who left the movement are similar in the way they act and in their religious outlook and goals. According to him, they all practice da'wa for the Qur'ann and the sunna of the Prophet. He called all of them Abl al-Sunna wa'l-Jamāa. When I asked him about the Salafiyya in Kano, he responded: "Salafi orientation (Ittijä" al-Da'wa al-Salafiyya) is unstable because Kano is more a center of Sufism. Salafiyya is to be found more in Jos or Kaduna." ${ }^{237}$

From the different points of view shown above, the Izala movement can be classified as a Salafiyya movement since its primary focus is to fight innovation in Islam and to establish the sunna on the basis of al-salaf al-săli ih. Although most Islamic scholars tend to define al-salaf al-salith as the third generation after the death of the Prophet, it is difficult to trace the origin and exact time of this generation. The Encyclopaedia of Islam divides the three generations into: the golden age, a second period of "relaxation of standards and deviation," and a period of division. It was the generation of the

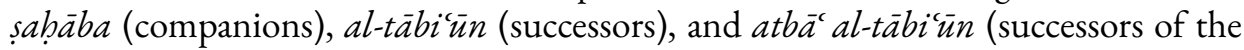
successors) that are considered the "norm" and the "model" for all Muslims, called alsalaf al-sălih. When this period ends is debatable. It should be noted that some scholars consider only the period of the companions as the age of al-salaf al-șalih. In addition, there is a differentiation between traditional and modern Salafiyya (Chaumont 1995: 900). The Izala movement, with both its branches, sees itself in that tradition of Salafiyya. Of course, it is difficult for the movement to build its silsila - if we can use a Sufi terminus - in the tradition of Salafism.

When it comes to Wahhābism, it seems to be more incomprehensible. The claim that the Izala movement is a manifestation of the Wahhäbi movement is due to the same reasons. First of all, the Izala movement's "spiritual father", Sheikh Gumi, was linked to Saudi Arabia and to Wahhābism. Secondly, the Izala movement itself uses

236 Yandaki relies here on Kaba (1972).

237 Interview with late Sheikh Jáfar Mahmud Adam in Kano, 2 January 2007. 
the books of Sheikh Ibn 'Abd al-Wahhāb, especially those which deal with tawhìd, the oneness of God. Ibn 'Abd al-Wahhāb (d. 1792) himself was influenced by the two Hanbalī scholars Ibn Taymiyya (d. 1328) and Ibn al-Qayyim al-Jawziyya (d. 1350), and he depended on them in many issues. The historian Michael Cook concludes that this "dependence provides the target for some of the earliest attacks on the doctrines of the Sheikh" (Cook 1992: 199-200). Concerning the prevalence of shirk, Ibn 'Abd al-Wahhāb was influenced by the Islamic scholar Ibn al-Amīr (b. 1688) (Cook 1992: 201).

It is known that the name "Wahhābr̄" was given to sympathizers of Ibn 'Abd alWahhāb's teachings. Wahhābis distinguished themselves as al-Muwaḥhidūn (the puritans) or abl al-tawhid (people of the oneness of God) (Algar 2002: 1). Algar, specialist of Persian studies, warns that there is no connection between the Wahhābiyya movements that we know in different parts of the world today and the initial stage instigated by Ibn 'Abd al-Wahhāb. The author rejects the idea of identifying Wahhābism as a reform movement that mushroomed to the rest of the Muslim world (Algar 2002: 4-5). He points out the connection between Ibn 'Abd al-Wahhāb and Ibn Taymiyya mentioning that the latter used to be a member of a Sufi order unlike the former (Algar 2002: 10). The misinterpretation of Wahhābism started - according to Algar - with the formation of the first Saudi state during the mid- $18^{\text {th }}$ century. The founders of that state proclaimed jihād against all who opposed their understanding of tawhìd. Those who opposed their doctrines were declared mushrikün (in Arabic: polytheists) and apostates (Algar 2002: 20). Returning to the doctrine of Ibn 'Abd al-Wahhāb, Algar stresses that the Sheikh concentrated on tawhid and especially on one particular type of it: tawhìd al-ibada (in Arabic: oneness in worshipping context). Algar consider this fact important when it comes to shirk (Algar 2002: 31). ${ }^{238}$

There is a similarity between that doctrine of the Wahhäbiyya and the formation period of the Izala movement. The Izala movement developed its own arguments, attacked Sufis in the past and declared their practices as an act of shirk. Additional prayers and Sufi-beliefs are irrelevant for the Izala movement and cannot be found in the tradition of al-salaf. One common thing between the Izala movement and Wahhābism is that both use the concept bid'a in a negative way. Algar clarifies it in the following: "This concept has been defined as "an innovated matter not followed by the Companions or the Followers and not part of that which a legal proof (dalil shar î) necessitates" (Algar 2002: 35). According to Algar this rejection of Sufism, the attachment to the tradition of al-salaf al-salih and the abandonment of affiliation with a particular Islamic school of law seems to be a common feature of Wahhābiyya and Salafiyya (Algar 2002: 47). Algar makes the distinction between both on the basis of two elements:

\footnotetext{
${ }^{238}$ Algar lists three types of tawhìd; tawhìd al-rubübiyya, al-asmä' wa'l-sifiät, and al-ibäda (Oneness of God; of his attributes; worshipping).
} 
Two important and interrelated features have usually served, however, to distinguish the Salafis from the Wahhabis: a reliance on attempts at persuasion rather than coercion in order to rally other Muslims to their cause; and an informal awareness of the political and socio-economic crises confronting the Muslim world (Algar 2002: 47).

The Izala movement can be placed in the Salafiyya tradition with Wahhābiyya influences. It is also part of Abl al-Sunna wal-Jama $\bar{a}^{c} a$ as are most Sunni Muslims and movements. The Izala movement defines itself as "fighters" against innovation and as establishers of the sunna of the Prophet. Tawhid plays a crucial role in the movement's doctrine. The Izala movement relies on the teachings of Ibn 'Abd al-Wahhāb, but also on other Islamic scholars like Ibn Taymiyya, Imām Mālik, al-Albānī, and many others. The Izala movement thus can be more closely identified with the Mālikī and the Hanbali School of law, although as mentioned above, it does not restrict itself to a particular school of law.

\subsection{The Izala divided ${ }^{239}$}

In most northern Nigerian states (and the whole country), institutions (schools, mosques, hospitals, etc.) of the Izala movement are divided into followers of two centres: Jos and Kaduna. The Jos faction and its current headquarters in the Sarkin Mangu neighbourhood of Jos tries to keep the flag flying for the tradition of the founder, Sheikh Idris, and his doctrine. The Kaduna faction is made of those who opposed him and chose to deviate from his path. Even if they decided to give their organization a new direction, they stick to the same name. Kaduna as the former capital of the northern Region is also symbolic for Muslims of the north. Of course, there are those who witnessed the development of Izala movement and never belonged to one of the two factions; and those who were members of the movement and left it at different stages. The division commenced in the mid-1980s. It was related to ideological differences in the movement. As a result, a separation at the level of institutions took place. Both major factions kept the initial constitution of the organization.

I summarize the reasons of the division in four major elements: ${ }^{240}$

\footnotetext{
239 Dealing with the division of the Izala movement here is more focused on the discourse going on in the society and by no way a trial to side with one or the other faction.

240 On 7 February 2007, I presented a paper at the Department of Religious Studies, University of Jos, Nigeria, summarizing the reasons for the division of the Izala movement into two major groups (Jos and Kaduna factions). Many Izala Jos followers (mostly students) attended the seminar and questioned the reasons for division, especially those of money-issues and the person of Sheikh Idris. This presentation opened the door for me to meet the actual leader of the Izala movement and other personalities of the movement in northern Nigeria.
} 
a) Questions of leadership, especially the position of 'ulama's' in the organization. Members of the Jos faction consider the late Sheikh Idris, the head of the Council of ' $u l a m \bar{a}$, to be the highest authority of the organization. Izala Kaduna regarded Musa Muhammed Mai Gandu, the head of the Council Administration, as the true leader of the Izala movement at that time.

b) The issue of finances of the organization: there was a discussion as to whether donations were directed to the Izala movement as an organization or to the person of Sheikh Idris.

c) Doctrinal divisions, especially when it comes to takfir (declaring for nonbeliever) and the relationship with other Muslims.

d) The person of Sheikh Idris and his way of managing the Izala movement: one crucial question was raised as to whether he is an ordinary preacher or the highest religious authority of the movement. These issues will be discussed in the coming paragraphs.

\subsubsection{The time of the division}

The division of the Izala movement took place after the celebration of the thirteenyear existence of the organization. All the Izala movement leaders, members, and sympathizers were invited to join the celebration in Jos. This date was symbolic for the movement and meant its attachment to the sunna of the Prophet. It was not by chance that the event coincided with the hijra of the Prophet from Mecca to Medina (which also occurred after 13 years): "The Prophet also spent the time [of the hijra] inviting people to Islam and introducing his message before he migrated to Medina." ${ }^{241}$ In the end, this event that was thought to be a celebration turned into an event of accusation.

Ousmane Kane spoke of a "process of domestication that led to the break-up of the society (i.e. the Izala movement, RbA)" (Kane 2003: 207). ${ }^{242}$ He believes that efforts by political institutions to limit the influence of the Izala movement and to restrict its emergence at the end of the 1970s and into the mid-1980s created problems in the organization. Kane regards measures taken by Maj. Gen. Muhammadu Buhari (Head of State from 1983 to 1985) as "backlash" to the Izala doctrine (cite). As the head of state, Buhari grasped the nettle in order to restrict religious preaching and the building of new Friday mosques without permission (Kane 2003: 208-209). Also, the relationship between Buhari and Sheikh Gumi seems to have affected the movement as a whole. Izala preaching in Kano from the beginning of the movement until the

\footnotetext{
${ }^{241}$ Interview with Dalha Abubakar Abdallah, 18 February 2007, Lagos.

${ }^{242}$ Preaching and establishing new mosques/bringing many mosques under their control were two of the most successful strategies followed by the Izala movement at an early stage of the establishment; see also Loimeier 1997a: 216.
} 
mid-1980s was not permitted. The situation changed after the bloodless coup d'état of General Ibrahim Badamasi Babangida (1985-1993), whose administration, according to Kane, supported more reforms (2003: 210-211).

Taking Kano State as an example, a trial to "turn the preachers to an institutional channel for negotiation with the state" (Kane 2003: 217) - in this case A.K. Daiyyubu, former Izala movement leader in Kano - is one of the many explanations for the split. According to Kane, Daiyyubu organized the Izala movement in Kano and succeeded in becoming a representative of the movement by the end of the 1980s. Daiyyabu used his role in the Izala movement to clarify his position vis-à-vis the state and its policy. ${ }^{243}$ Kane expected the "ulamä" of the Izala movement to be "frustrated" over being "relegated to the background" (2003: 220). This is, of course, a good example that shows the kind of problems the movement had to face. Apart from the internal dogmatic controversies between leaders of Izala movement, the organization was used as a forum for propagating individual ideas and points of view. This is what Kane called an attempt to use the Izala movement as a "channel of negotiation with the state" (Kane 2003: 222). Another reason leading to the break of the Izala movement can to be explained by the fact that "patrons of the movement" who were also part of the state apparatus tried to exercise power over the Izala movement. As examples of this strategy Kane mentions the cases of Daiyyabu in Kano and an Izala leader in Borno who were both dismissed in 1990. The issue of the split mentioned above was in the context of Kano state. Concerning the Izala movement as a whole, the conflict between Sheikh Idris and Musa Mai Gandu escalated. It was a kind of struggle for power within the movement. The monetary aspect also seemed to play a critical role in the division. In 1991, the two parties of the Izala movement started "discrediting each other" (Kane 2003: 222).

The crisis of the Izala movement started in the mid-1980s and intensified at the beginning of the 1990s. The Gulf war between 1990 and 1991 can be considered an external factor influencing the Izala movement. The leaders of the organization were divided between those who supported Saddam Hussein in his invasion of Kuwait and those who opposed it. Interestingly, two groups within the movement emerged: Saddamawa (supporters of S. Hussein) and Bushawa (named after G.H. Bush; supporters of the Saudis). The entire discussion developed from the question of whether Saddam Hussein was permitted to invade a Muslim country (Kuwait). In addition, a heated debate arose among the Izala movement as to whether it was permitted to station American troops in Saudi Arabia. The events are described by Sani Modibbo as follows:

\footnotetext{
${ }^{243}$ Kane mentions how A. K. Daiyyabu criticized the new government population policy. During an Izala movement meeting in Kano, 1989, Daiyyabu turned the event into a "one-man-show"- as described by Kane- to heavily denounce the implementation of a so-called structural adjustment policy (SAP) through the government (see Kane 2003: 218-219).
} 
When Saddam invaded Kuwait, Mallam Ismail was not in favor of supporting the invasion and then condemned the act and he also supported the Saudis for giving Americans military bases in the Holy Land. We were not active in the Izala movement when this controversy emerged. It was around 1990, isn't it? Around 1991 was the Iraqi invasion. So politically the 'ulamä', those 'ulama' who said: 'let us fight, said let us support Mallam (Idris).' They were also divided. Those who said: 'no' although they were not supporting Saddam $100 \%$, they disagreed; they condemned the Saudi Government for providing these Americans with military bases in the Holy Land because they will bring 'fassad' (decline). And Mallam came out and said that they are right, they were right and have right. ${ }^{244}$

There are several speculations about the event and the Izala movement's reactions to the Gulf War. Some views took the opportunity to confirm that Sheikh Idris was sponsored by Kuwait, ${ }^{245}$ and that was why he opposed Saddam Hussein. In absence of any evidence, such a claim can be neither verified nor falsified. The Izala movement is known to Nigerian Muslims as a self-reliant organization in matters of finances. It is possible that during a very early stage, the Izala movement was financially assisted by networks associated with Sheikh Gumi outside of Nigeria, but it is very difficult to find any proof. When asked about possible financial support to the organization originating from Kuwait and the fact that Sheikh Idris opposed the invasion of Kuwait, the Izala leader in Lagos (Jos faction), Dalha Abubakar Abdallah, gave the following answer:

From the Sheikh's standpoint, we are not allowed to rely on any Arabic country, and what Arabs give as financial support is only for the improvement of Islam and also for the purpose of reaching paradise. And when he asked us if we don't like al-Janna (paradise), we said that we do like it, and he continued: 'we should rely only on ourselves and on what we have. I don't know if Kuwait supported the organization but I don't agree with it. It is not true 246

Interestingly, when leaders make decisions in the Izala movement, they try to link followers to their views and interpretations. This has social implications in the movement, like warning followers about getting married to a member of the group of opponents within the movement: "And even when I heard, that even your daughter is married to a Saddamawa, that marriage is annulled and thus void. So we have a controversy now." ${ }^{247}$

\footnotetext{
${ }^{244}$ Interview with Sani Modibbo, 28 February 2007, Jos.

${ }^{245}$ Loimeier mentions that Yan Izala movement and Sheikh Gumi were supported by the Saudis and

Kuwaitis (see Loimeier 1997a: 287).

${ }^{246}$ Interview on 18 February 2007, Lagos.

${ }^{247}$ Interview with Sani Modibbo, 28 February 2007, Jos.
} 
Besides the concern at the social level, followers within the Izala movement are warned against opponents, but it also often becomes an identity issue of being Izala movement or not: "If you are Saddam's supporter for any cause, if you support Saddam, if you support the course of Saddam, you are not an Izala." ${ }^{48}$ This is quite a widespread phenomenon in the Izala movement. Even today the question of authenticity is crucial within the movement. Being Izala movement requires for example identifying with the founder Sheikh Idris and his fatāwa for the Jos faction. Furthermore, it also requires protecting him in all directions (see chapter "The War of Word"). For the Kaduna faction, guidance by other 'ulama' in the organization is more important.

To conclude, the major problem causing the division of the Izala movement started in the mid-1980s. This was a period marked by political instability. In 1986, and during the presidency of Babangida, the OIC-controversy was highly debated. ${ }^{249} \mathrm{In}$ addition, the Muslim community in Nigeria witnessed events like the Maitatsine riots in 1980. Finally, the long lasting Sufi-Izala conflict over doctrines turned into a violent struggle several times. Furthermore, after being officially registered in 1985, the Izala movement entered into a phase of "consolidation" and at the same time tried to "cleanse itself" (from the Maitatsine riots and all accusations against the Izala movement) - as Yandaki emphasizes. Yandaki identifies in fact the period between 1982 and 1988 in the history of the Izala movement as a "phase of consolidation". During that time the Izala movement started growing and became "more tolerated in the society" (Yandaki 1990: 159-164); the Izala movement also tried between 1982 and 1984 to polish its image and distance itself from the Maitatsine events of the 1980s (Yandaki 1990: 163).

The period of division of the Izala movement was unstable both within and outside the movement. The pressure on leadership was strong. A new and fast-growing movement like the Izala movement faced challenges and ended up dividing into two major groups. In several parts of northern Nigeria, signs of division became more visible and influenced the movement. In Sokoto state, for example, Sidi Attahiru, one of the major figures of the movement, broke with the Izala movement in the mid-1980s and publicly disassociated himself from the Izala movement before joining a Sufi brotherhood. The case of Usman Dangungu is also well-known. He was very influential among the youth. In 1983, he criticized the governor of Kano in an audiocassette recording. Afterwards he was "excommunicated" from the Izala movement. In Kano, and during the same period, the Islamic scholar Aminud Deen Abubakar left the Izala movement and established his own movement. Sheikh M. Sanusi Gumbi (based in Kaduna today) struggled with the leadership of the Izala movement and left the organization (Yandaki 1990: 163). ${ }^{250}$ The coming paragraphs will deal with the reasons

\footnotetext{
248 Interview with Sani Modibbo, 28 February 2007, Jos.

249 See Hock (1996) for more details on this issue.

250 Yandaki gives different examples showing that the division of the Izala movement was a question of time in the mid-1980s a question of time; for more details from different regions of the north (see Yandaki 1990: 176-180).
} 
for the division. It is in no way an attempt to make any group or person in the Izala movement responsible for the division; rather, it is only an analysis of discourse and arguments from different angles.

\subsubsection{Reasons for the division}

In his study on different Islamic institutions in Nigeria, A. Lawal Adam summarizes four reasons for the division of Islamic groups: political (Arabic: siyāsa), faith (Arabic: 'aqìda), behavior (Arabic: sulük) and fanaticism (Arabic: 'asabiyya) (Lawal Adam 1992: 45-46). In fact, a division of any religious movement is often due to internal and external reasons. The Izala movement is not an exception in this respect. In the movement itself, as well as in the entire country, the split damaged the image of the movement in many ways. Nevertheless, following the crisis within the Izala movement, the same constitution and structures were kept.

The majority of people inside and outside the Izala movement confess that the issue of division was not at the level of 'aqida or about the goals of the organization. The type of leadership of the founder and his relationship to other 'ulama' of the movement as well as to other leaders of the organization created a fissure within the Izala movement. Of course, one cannot deny the general situation during the time of division on many levels: economically, politically, and religiously. There are many reasons that led to the division of the Izala movement into two major groups. The 1970s was a time of economic instability and political turmoil in Nigeria. Apart from the discussion on the new constitution of 1979, a series of ethno-religious clashes took place in the West African country. Additionally, events in the Islamic world affected the Izala movement one way or another.

Gurama stresses that the media played a significant role in escalating the situation during the 1980s between the Izala movement and the Sufis. ${ }^{251}$ Furthermore, Gurama related the crisis of the Izala movement to other crises in the Muslim world: He mentions, among others, the Gulf-War, the case of Algeria during the 1990s, the shari'a debate in Nigeria, the Palestinian-Israeli conflict and the war in Bosnia during the 1990s (Gurama 2000: 70). Concerning the division of Izala movement, Gurama lists several reasons. Among others, some scholars left the Izala movement since they refused Sheikh Idris' leadership. In addition, there were some tribalistic issues; some scholars were still affiliated with Sufism and Sufi practices; there was the involvement of Shî 'ites in the movement; the use of the organization to achieve leaders' personal goals; the call to separate a women's wing of the Izala movement; and the so-called academic terrorism i.e. deviating from the Mālikī School of Law (Gurama 2000: 72-74). Gurama speaks of secret meetings to impeach Sheikh Idris and compares what happened in the

\footnotetext{
${ }^{251}$ See Gurama (2000: 62-65). Most of the events described by the author are articles related to the Maitatsine riots of the 1980 written by Sufis and Izala movement leaders. The Izala movement was accused of acting irresponsible in this period of time. The Izala movement defended itself and distanced itself from the Maitatsine riots.
} 
Izala movement to what happened to Sheikh Gumi when he left the JNI. Furthermore, Gurama speaks of propaganda against the founder of the Izala movement. According to him, Sufis also got involved and used the situation to circulate "baseless stories" on the Izala movement (2000: 77). Gurama also mentions an important meeting held in Hadeja, Jigawa State, for the purpose of impeaching Sheikh Idris. The result of the meeting was the decision that the founder of the Izala movement should be expelled because of using law for his own purpose, calling people "non-believers," preferring things that contradict Islam as well as considering tariqa people to be mushrikin (in Arabic: polytheists) (Gurama 2000: 78).252

In 1991, after the struggle within the Izala movement, a declaration over the Radio in Kaduna was made that Sheikh Idris was not leading the Izala movement council of 'ulama' anymore and was replaced by Sheikh Rabiu Daura. In addition, the head of the First Aid Groups, Alhaji Issa Waziri, was removed from his position. Many other changes at the level of leadership were made by the Kaduna faction of the Izala movement. All these decisions were explained by the fact that Sheikh Idris handled matters individually, refused advice, used the organization's money for his own purposes (donations in matters of books or cars), and announced the thirteen-year anniversary celebration of Izala movement without the consultation of other 'ulamä (Gurama 2000: 81-82). The answer of Sheikh Idris himself reflects his point of view: "Even if a non-Muslim is asked who founded Izala movement, he will tell you that Isma' ila Idris founded it" (Gurama 2000: 86). As an explanation of the crisis within the Izala movement given by the founder of the movement, Sheikh Idris spoke of the selfish interest of many people involved in the Izala movement, Shī'a involvement in the Nigerian society, revival of innovation through some preachers, and opposition to a women's wing of the Izala movement (Gurama 2000: 86). As Kane shows, the issue of leadership of Sheikh Idris is mentioned as a reason for the division. Apart from that, money seems to play a role in the split.

In the following, the reasons for division are analyzed from different perspectives: from the perspectives of leaders in Jos and Kaduna; from the point of view of some former Izala followers; from the perspective of ordinary members of the movement and of those who never joined Izala movement. For the current leader of the Izala movement in Jos, Sheikh Jingir, the division of the movement is due to three major reasons. According to him, one of the reasons is the Shī'a influence of some preachers of the movement:

... the influence on some preachers by Shī ite ideas, which came to Nigeria and spread out. The da'wa started by telling people not to go to schools belonging to the state and so on. Some students left their schools since these institutions were under a taghut (Satanic, tyrannic) rule. This is one reason. ${ }^{253}$

${ }^{252}$ Gurama also quotes a pamphlet in Hausa written by Sheikh Muhammad Umar Nasarawa, Adamawa state leader of the council of 'Ulamä' and affiliated with the Kaduna faction of the Izala movement. ${ }^{253}$ Interview, 28 February 2007 (my translation from Arabic). 
Sheikh Jingir adds that some preachers who belonged to political institutions of the state influenced the movement. In addition, some people blamed Sheikh Idris for using the money of the Izala movement for his own purposes. Furthermore, they complained about his inability to obtain financial support from Arabic countries. ${ }^{254}$

Sheikh Yusuf Sambo, the leader of the Izala movement (Kaduna faction) saw a structural misunderstanding behind the whole issue of the Izala movement. In his opinion, since the establishment of the organization, Alhaji Musa Mai Gandu was and is the leader of the Izala movement. He mentions that since the Izala movement is a religious organization, a Council of 'ulam $\vec{a}$ 'was established during a meeting held in Kaduna. Leaders of the movement elected Sheikh Rabiu Daura, but since Sheikh Idris was the founder of the Izala movement, he was given the position. He agrees that the conflict was in no way a matter of faith. He points out: "As we removed Sheikh Idris from his position, they refused. They said: "this is not possible! Nobody can say this or that."'25s And he adds: "They blame us for being Shī'a and Saddamawa (followers of Saddam). They blame us for many things, but we don't answer them." ${ }^{256}$ This view was confirmed by Sheikh Ali Abdallah Telex, the Izala leader in Zaria (Kaduna branch). He confirmed that Alhaji Mai Gandu was and is still the leader of the Izala movement as a whole:

Money; I think it was monetary issues. They insulted each other. I would also say that the problems are also political because when the conflict matured, they started insulting each other's in some cases - as I said. The political conflict reached the leader of the Council of 'ulama' of the Izala movement: Sheikh Ismaila Idris. The organization was founded on three basic elements: 1) the Administrative Council, which is the strongest; 2) Aid groups; 3 ) and knowledge and education. The problem took place at the third level among the 'ulam $\vec{a}$. The monetary and political problems among the 'ulam $\vec{a}$ ' affected the entire movement until the "Jossawa" (people of Jos) and "Kadunawa" (people of Kaduna) were established. They are known by this name even today. I really know that the ones who belong to Izala movement in Kaduna try as much as possible to reconcile, but until now without success. People of Jos are hardliners in the context of this conflict. They want to continue the conflict to prove that they were the initiators of the organization. This is not true because the first leader of the organization was Musa Muhammad Mai Gandu - he is still alive - and the people of Kaduna are today on his side. Mai Gandu was the first leader and even Sheikh Ismaila Idris was under his authority. Most of the names given to the government for registration of the organization were from the Kaduna fac-

\footnotetext{
${ }^{254}$ Interview, 28 February 2007 (my translation from Arabic, RbA).

255 Interview with Yusuf Sambo, 15 January 2007, in Kaduna (my translation from Arabic, RbA).

256 Interview with Yusuf Sambo, 15 January 2007, in Kaduna (my translation from Arabic, RbA).
} 
tion. There were five: two of them died and three are still alive. From the three alive, there are two in Kaduna and one in Jos. ${ }^{257}$

For the Kaduna branch of the Izala movement, Sheikh Idris - although he was the founder of the organization, is considered to be an 'alim by many Izala members. According to them, he was neither the leader nor was he registered as such. They criticized his lack of transparency in guiding the Izala movement in financial matters. The question was often raised as to whether money (also other donations like cars, etc.) was donated to Sheikh Idris as a person or to his organization as an institutional body. Accusations and counter-accusations regarding the financial management of the Izala movement played an important role in the division. The discussion about the structure of the organization also took place. The main question concerned the structure of the movement: what is its paramount body? Is it the Council of 'ulama' - since the organization is a religious one? Or is it the Council of Administration? Who was leading the Izala movement? Is it Sheikh Idris, who is an Islamic scholar, or Alhaji Mai Gandu, who was not a scholar?

The struggle within the Izala movement was directed against Sheikh Idris, accusing him of selfishness in guiding the organization, but also for violating the constitution. Sheikh Idris blamed his opponent's deviation and rebellion against him. The actual leader of the Izala movement in Lagos (linked to Jos faction), Dalha Abubakar Abdallah, describes the situation as follows:

In the center of accusations was Sheikh Ismaila Idris. Those who split from him accuse him of being selfish in guiding the movement. They blame him of deviating from the initial goals outlined in the beginning. Sheikh Idris was charged with dominating the Izala movement and "breaking" its constitution. He was accused of going beyond his position as an "ordinary scholar" among many others and deviating far from the leadership of Musa Muhammad Mai Gandu. The latter is not an Islamic scholar but an administrator and official leader of the organization. From this turn, Sheikh Idris accused the group that deviated from his path of "rebellion" when they split from him - as the leader and architect of the organization. ${ }^{258}$

For Alhaji Ibrahim Musalla (Kaduna branch of the Izala movement, served as state treasurer of the organization at a very initial stage), the issue of division started in 1981 in Saudi Arabia when Sheikh Idris contacted the Muslim World League and introduced himself as the leader of the Izala movement. He was confronted by the fact that

\footnotetext{
${ }^{257}$ Interview with Sheikh Ali Abdallah Telex, 07 January 2007, in Zaria (my translation from Arabic, $\mathrm{RbA})$.

${ }^{258}$ Interview in Lagos, 18 February 2007 (my translation from Arabic, RbA). At another occasion, the interviewee compared the split of the group in Kaduna to the Kharijites, the first Islamic group who split from Caliph 'Alī during the seventh century (see Gurama 2000: 110).
} 
they recorded the name of Alhaji Mai Gandu as leader. Annoyed by this experience, Sheikh Idris started a struggle for power within the organization:

He went to Rabita and introduced himself as the leader of the organization. After sending the message, the officer asked him: "is he the one called Alhaji Musa Mai Gandu?"'He said: "no, he is Sheikh Ismaila Idris.” They told him that the man in their record is Sheikh Musa Muhammed Mai Gandu. He is the leader of the organization in Nigeria. "Did the organization have two leaders?" He said: "yes, he is the leader of the Imam committee, as Imam among preachers and Musa Muhammed Mai Gandu is the head of the entire organization's administration." That is according to him. They said "that they are very sorry and they can only attend to Musa Muhammad Mai Gandu as the leader in their record which they received from the embassy.” Then he was annoyed, and was very very angry. He was complaining about why he was suffering and that somebody else is taking all the credit. There is the beginning of the problem in the organization. The moment he came back, he started bulldozing his way around, looking for a way to turn against Alhaji Musa Mai Gandu and place the fault with him. ${ }^{259}$

The informant adds that according to the constitution of the Izala movement, the executive chairman of the entire organization is Alhaji Mai Gandu, who was elected by unanimous vote. When it comes to the council of 'ulamä' and the First Aid Groups, both are under the chairmanship of the administration council. This was rejected by Sheikh Idris who considered the 'ulamä' to be at the top of the organization. Furthermore, in the mid-1980s Sheikh Idris started excluding members from the organization. ${ }^{260}$

If some leaders of the Izala movement did not accept the way Sheikh Idris headed Izala movement, there were others who were also frustrated and left him because of a negative personal experience. An example of this is evident in the Jos-based Sheikh Alhassan Said Alhafiz, the former Qur'ān reciter under Sheikh Idris. He is now linked to the Kaduna faction of the Izala movement. Sheikh Alhassan Said points out that, from the beginning, he was on the side of the founder of the Izala movement and never thought of deviating from him:

I swear by Allah that I did not belong to any other group when I was with Ismaila Idris. I was with him until they removed him from his position. They organized a meeting at Hadija - the name of the town as I told you - and some brothers asked us to go there to that meeting so if they say something wrong, we can answer. Sheikh Idris agreed and appointed me as the leader of a committee that should go to Hadija and put a car under my disposition. We were on the

${ }^{259}$ Interview in Jos on 24 December 2006.
260 Interview in Jos on 24 December 2006. 
way to leave and he stopped us and said: "No!" He didn't want us to go there. Since we didn't go, they decided to remove him from his position. If we were there, this would not have happened. This is the will of Allah. ${ }^{261}$

Sheikh Alhassan Said adds that other reasons led him to join the Kaduna branch of the Izala movement. His relationship became worse with Sheikh Idris because of misunderstandings and wrong stories transmitted to the founder of the Izala. After leaving Nigeria to study at the Islamic University in Medina, Sheikh Alhassan Said came back for a visit in 1992/1993 and preached against the riya (in Arabic: hypocrisy) of some people. He was misunderstood and accused of bringing a "new religion" to the country. Furthermore, Sheikh Idris was angry with him and advised him to abstain from that type of preaching, which is not allowed among Abl al-Sunna. The situation escalated when Sheikh Said was accused of being a $\operatorname{shi}^{i} a$ follower:

He [Sheikh Idris] said: 'Where are you and your Shī'ite teachers?!' I said: 'me' and he added: 'yes! In the Islamic University there are a lot of Shí'ites.'No, no, no! By Allah, in the Islamic University there were no Shī' ites and I don't know any teachers who are Shī ite. Even if students, find out that another student is among the Shi' ites, they might kick him out of the University.' And he swears by God that the majority of teacher in the Islamic University are Shî' ites. I said: 'No! It is not like that'. (...). I said: 'No, look; Sheikh, the books of the sunna are different from those of Shī ites.' He mentioned some saying and I answered him: 'Sheikh! These are the statements of Mu'tazila.' Suddenly I had the Tafsiir of Dhahabi and I opened it and said to him: 'Look! These are the sayings of Mu'tazila and not of Abl al-Sunna. You are our leader, father, teacher and we will follow you according to the al-aqida al-sabih ha (in Arabic: the right faith), but if you come with the teachings of $M u^{\prime}$ tazila then we will not agree with you.' So he was angry and left. He also mentioned that if someone kills another person intentionally, he is a käfìr (non-believer) even if he repents. I said: 'No! This is the sayings of Charijites' and I opened the same book and showed him the proof. When a person kills a human being intentionally and if he repents then Allah will forgive him because Allah is the Forgiver and the Merciful. It is mentioned in the Qur'ān: 'I am the forgiver for those who repent...' And I showed him the places (where it was mentioned) as well as the hadith. This is what brought the Sheikh to say: 'You never come to me again!' I said: 'no, I will come and greet you. I consider you to be my teacher and Sheikh if you are mistaken, then I forgive you and I don't blame you for anything since you are a human being. This is the crisis that started between them and me. ${ }^{262}$

\footnotetext{
${ }^{261}$ Interview in Arabic with Sheikh Alhassan Said in Jos on 12 December 2006 (my translation, RbA).

${ }^{262}$ Interview in Arabic with Sheikh Alhassan Said in Jos on 12 December 2006 (my translation, RbA).
} 
Sheikh Alhassan Said adds that he joined the Izala movement in Kaduna when he was asked to do so by that faction. He was given the opportunity to be with al-haqq (in Arabic: truth) on the basis of the Qur'ān and sunna. From that time, he could not remember any blame or big issues within the Kaduna group of the Izala movement that led him to regret his choice.

This is an example at the top level of the organization of the factors that led to the division because of the founder of the Izala movement. At the grassroots level, people were more or less guided by emotions. In the Izala movement, there is no particular ritual or initiation into any faction of the organization. Given that followers are more directed by their own observations and interpretations of problems, they can easily stop their affiliation to one group or the other. If issues occur at the top level, interpretations of leaders circulate promptly and become well-known to members of the group. To identify with one faction means to be on the side of Sheikh Idris for the Jossawa group and against him in the Kadunawa faction. People who were in Jos and witnessed the Izala movement from its initial stage are mostly on the site of Sheikh Idris and follow his path. They also protect him against any accusation, be it concerning his leadership or concerning money.

Alhaji Khamis Zakariyya from Jos, who affirmed his attraction to the Izala movement and the preaching of Sheikh Idris since the early stages of the foundation, explains that the split of the movement is basically due to al-hasad (in Arabic: envy). He explains that there was a time when Sheikh Idris was given a new car by Mallam Hamza Abdallah. Sheikh Idris spent six months without using that car and then called the 'ulama' and asked them what to do with it. They suggested that he use it as a public car to generate some money. However, there were some people who were not happy with that decision:

Mai Gandu and other Izala leaders betrayed Sheikh Idris in order to get money from the organization and, in the process, excluded him. Even today they blame Sheikh Idris for taking the money of the Izala movement. In defense of the Izala movement founder, Alhaji Zakariyya mentions that Yusuf Sambo (leader of the Izala movement Kaduna) also collected money to build his house in Kaduna. That money, however, belonged to the organization. Also, Sheikh Alhassan Said received money (one million Naira) from the ex-governor of Bauchi, Muazu, and collected donations in Port Harcourt and Abuja. He used the money to build a house. Then Alhaji Zakariyya asked, astonished, whether Sheikh Idris collected money or not. After his death, they realized that he left behind only a house that was built by the organization for him. He confirms that he was present after the death of Sheikh Idris when his property was distributed among his children. Only a house was found. He says: "I swear that all the people present cried!" Each daughter of the Sheikh got 5,000 Naira and every son received 10,000 Naira. He concludes: "I know Sheikh Idris person- 
ally! I swear! He will preach from morning to evening without having a single Naira in his pocket! $!^{263}$

Of course, such a statement cannot be confirmed or denied because of the absence of any evidence. It only shows how complicated the money issue in the Izala movement is. The organization is based on donations - even today. Money is collected in mosques after prayers and at any big events organized by the organization. Money is accounted for and directed to headquarters (local, state or nationwide). Trust plays a crucial role at all levels. The definition of donations is also important: are they directed either to a person or to the organization? There are always those who blamed, and still blame Sheikh Idris for using the organization's money for his own purposes. The absence of clear evidence makes any accusation or counter-accusation void.

The growth of Izala movement particularly in northern Nigeria made control over it complicated. It is no wonder that money became an issue since the increase of the organization's resources. A struggle for power between the 'ulamä' and executive members of the Izala movement internally affected credibility and transparency in the organization. Many questions were raised within the Izala movement: are 'ulamáa only preachers or can they also act as treasurers of the Izala movement? Can money go to individual accounts of 'ulamä' or only into the account of the organization? If it goes to the "ulamä"s account then how can the organization know about that? Is that money a private one or does it belong to the Izala movement as a whole?

Ustaz Sani Modibbo, who held several positions ${ }^{264}$ in the Izala movement since its establishment and was familiar with its internal affairs, illustrates how the issue of money developed into one of reasons for division in the Izala movement. To some extent he considers money to be one of the major sources of the split:

Money is one of the major factors because when the 'ulamä' decided to have their own accounts, we said: "no!" at that time; because the account was for the organization. Nothing was wrong if one of the 'ulama', if Ismaila himself was the signatory to the account, but they should not have a separate account. Anything belonging to the Izala movement should go into the main account. Later on we heard that they had their own accounts in case there is a donation from an individual. So if you are donating to account $A$, the executive will not have any idea; if the donation goes to the account of the executive account, then everybody will know. And then there are audits; and we have audit unit and an

\footnotetext{
${ }^{263}$ Interview with Alhaji Khamis Zakariyya in his shop in Jos, 14 February 2008 (interview conducted in Hausa with simultaneous translation into Arabic by Mallam Sani Abdurrazzaq).

${ }^{264}$ Ustaz Sani Modibbo served as Secretary General of the Nasarawa-Gwon-Branch (Jos) between 1979 and 1985; State Secretary General in Plateau State from 1985 to 1986; Administrative Secretary 1985/86; National Executive Secretary 1985/1986 to 1987; National Escort Member of the organization.
} 
auditor who will come and audit the account. (...) the monetary issue; one cannot deny that. Really! ${ }^{265}$

The structure of the Izala movement as a modern religious movement organized along regulations similar to state institutions (well-established structure, documentation, constitution, etc.) does not guarantee equality or transparency. The religious leaders and 'ulamá' of the organization enjoyed, and still enjoy a special status and are in positions of power. It is difficult to control them and adapt them to the law or to the constitution of the organization. They feel that they are the law-makers and controllers of the organization; and when it comes to money, they see themselves in a position of trustees. They are the ones who bring in money and they are the ones who control it, save it or distribute it in the name of the Izala movement. They are the policy-makers and the "religious capital" of the organization. So how can they mollify any regulation or law?

Many interview subjects attested that the division of the movement was not because of the doctrine or concerning faith. This is also explained by the fact that both kept the same name even after the division:

Indeed! Both kept the same name because their problem was not a basic one that concerned ideology. There was no need for changing the name. They did not split because of crucial, basic, or principal issues, but because of new economic problems; maybe you can say mashäkil dunyawiyya (in Arabic: problems of this world). ${ }^{266}$

As an outsider of the Izala movement, the late Sheikh Ja'far Mahmud from Kano, related the division in the Izala movement to fitna ${ }^{267}$ (in Arabic: secession, upheaval) within the movement. He added that the financial aspect cannot be ignored as a reason for the division of the organization. According to him, the property of the jamác $a$ (community; Izala movement) especially seems to be a source of debate. In addition, the intervention of politicians and ethnicity played an important role in splitting the movement:

Despite that the jamác $a$ was founded by loyal people, their knowledge is very limited. Of course, if the number of followers increases and the leaders don't have the proper knowledge, experience, or study of old experiences of the da'wa-work, this leads to division among people. The second issue is the attempt of some politicians to divide the jamāeca into two. This happened with

\footnotetext{
265 Interview in Jos with Ustaz Sani Modibbo, 28 February 2007.

${ }^{266}$ Interview in Jos with Ustaz Muhammad Khamis Idris, 11 December 2007; former Izala member.

267 This concept is mentioned in the Qur'an. Its meaning is related to division, chaos and the situation of war. In Islamic History, the first civil war is known as al-fitna al-kubra. It took place after the death of the third "rightfully guided Caliph" Uthman (d. 656).
} 
the first founder of the Izala movement, Ismaila Idris, when they tried to seek revenge on him by separating people from him and inventing issues within the movement. They (politicians) used some members to harm to Sheikh Idris and blame him for things that only Allah knows whether they were true or not. Well, these things were mostly right. They (politicians) fear that the Jama'a spread out in a short amount of time and see in it a danger in the future. They tried to destroy it in this way. They opposed it by arresting people and by involving their own agents in it. Well, maybe these are the main reasons. People also say that al-taasșub al-qabalī (ethnicity) played an important role. You find ethnic differences everywhere and that can lead to an attempt to dominate the whole organization. This could also play an important role in the division. ${ }^{268}$

When asked about the role of Sheikh Idris as a founder and leader of the Izala movement in dividing the movement and increasing opposition within leadership, Sheikh Jaafar added:

Indeed, he was a very strong person towards others. He expects more from people than they are capable of. He has very strong and rigid ideas without any flexibility. If he would deal with issues with some of deliberation; maybe it would be better. But he was tough on the ones who agreed with him as well as on the ones who opposed him. He took things seriously. This exacerbated some sensitivity between him and others who wanted to eliminate him from power. Through that, maybe the Jama'a can be rescued from his "religious dictatorship." ${ }^{69}$

In the same town, representatives of the Izala movement have the choice between Jos and Kaduna and to decide about the authenticity of each group. Certainly, there are Izala adherents who do not belong to any faction and who see themselves as members of the Izala movement as a whole. Alhaji Abba Damburno, for example, introduced himself as one of the founding fathers of both groups. Not only did he witness the establishment of the Izala movement, but also its development at many stages during the last 30 years. As reasons for division he mentions is the "love of leadership and material things." ${ }^{270}$ Also the above-mentioned Ustaz Sani Modibbo, who resigned from his office and left the Izala movement in the mid-1980s, clarifies that he in fact distanced himself from the Izala movement as an organization, but still entertains a good relationship with all the leaders. Is it possible to speak of a third group of the Izala movement? Maybe an Izala movement "C," or a third faction?

\footnotetext{
${ }^{268}$ Interview with late Sheikh Jaafar Mahmud Adam in Kano, 2 January 2007. The Sheikh assured me that he was outside of the country studying during the time of division and his point of view was based on news that he received from Nigeria but also through his own observation of the whole situation.

${ }^{269}$ Interview with late Sheikh Jaafar Mahmud Adam in Kano, 2 January 2007.

${ }^{270}$ Interview with Alhaji Abba Damburno (also known as Abba Eldanna) in Jos, 24 December 2006.
} 
Gurama speaks of a "third group C” in Izala movement and categorizes Medina students who broke with the Izala movement when they came back to Nigeria as part of this third faction. They are called "Yan Medina" (in Hausa: people of Medina; literally, those who studied in Medina). Under this category, he classified Sheikh Jaafar Mahmud Adam. ${ }^{271}$ Of course, this third "group" of the Izala movement is more heterogeneous than the two other factions, and it is neither organized under one name nor does it have visible or well-known leaders and representatives in the north. During my field research in Nigeria, I heard the following statement several times: "Those who studied abroad left Izala movement when they came back!”

\subsubsection{The Izala "war of words" between Kaduna and Jos ${ }^{272}$}

This chapter will examine the struggle between the two Izala factions, demonstrated by their publications: the first is entitled risalātān maftubatāni ilā zacim al-jamāa al-ismäiliyya, al-Sheikh Sani Yabya Jingir (in Arabic: "two open letters to the leader of the jamā'a al-ismā'iliyya" [named after Sheikh Ismaila Idris, the founder], Sheikh Sani Yahya Jingir). This document ${ }^{273}$ was written by Dr. Ibrahim Jallo Muhammad, the second deputy of the leader of the Council of 'ulamä, Izala Kaduna. Jallo is also the leader of the Izala movement in Taraba State. The reply to this publication was kalimāt wajīza li-qam'sharr al-ḩasūd (in Arabic: "short words to overwhelm envious people's evil") written by Saleh Idris Muhammad. ${ }^{274}$ The current leader of the Izala movement in Lagos (linked the Jos faction), Dalha Abubakar, also wrote a booklet with the title al-radd wa'l-nașina (in Arabic: "the answer and advice") responding to the statements of Dr. Jallo's document. The aim of this section is to illustrate the doctrinal debate through the analysis of these books.

The publications mentioned above are written in Arabic and show the high level of discourse achieved by the leaders of the two different Izala movement groups. Arabic is the language of the Qur'ān and the sunna. This language is not accessible to every Nigerian Muslim. Only scholars who have attained a particular level of intellectuality

\footnotetext{
${ }^{271}$ Gurama speaks of Izala movement A, B, and C. He sees the first one as extreme in "interpretation and application of Islam" and uncompromising, the second one called Yan Tawaye (the seceders) as liberal and moderate, and the third one as trying to maintain "spirit of neutrality" (see Gurama 2000: 114-116). During my own interview with late Sheikh Jaafar he did not confess any affiliation to the Izala movement before he left to study in Medina. Concerning the third group, he observed its existence adding that they are not organized and act individually. Interview 2 January 2007.

${ }^{272}$ I am using the word "war" neutrally and as a metaphor. It is to be understood as debate, dispute or disagreement. This term is used in Falola (1998): Violence in Nigeria.

273 The choice to put the word "book" between quotation marks indicates the uncertainty about the publication and the year.

274 Thanks to Saleh Idris Muhammad for providing me with copies of these two publications. It is indicated that the booklet was printed in Jos on 13 January 2006. There is no mention about the publisher. It looks like the many Izala movement-Jos material printed by the headquarters and circulated among members and institutions.
} 
can understand and speak it. The ability to write well in Arabic is an advanced stage of mastering the "sacred" language of Islam. Interestingly, this type of polemic writing is reminiscent of the polemical writings of Sheikh Gumi about Sufism and the answer from the Sufi brotherhoods. ${ }^{275}$ Writing in Arabic seems to be a common practice among Muslim intellectuals in Nigeria. The "religious capital" is not only based on reciting the Qur'ān and having knowledge of the Islamic tradition, but also on achieving a high level of proficiency or even fluency in Arabic. Most of the leaders of the Izala movement have mastered Arabic and prefer to write and publish in Arabic.

The goal in the following paragraphs is purely analytical and by no way a search for the theological legitimacy of any statement. In Islamic theology - like in any other theology - the door of $i j t i b \bar{a} d$ is open. Many issues are still debated among the 'ulam $\vec{a}$. The purpose of the next part is to depict the argumentation of both parties. The internal debate is known by many Izala insiders. Non-Izala Muslims are often aware of the split within the organization, but without knowing its reasons. I was accidentally drawn to these books through interviews conducted in Jos. The language of these texts often changes from the objective argumentation (showing sources, quoting classical theologians, etc) to subjective criticism (mentioning of names, blaming ignorance/lies/rumors, defending the leaders, etc). In these publications, the issue of bid' $a$ is surprisingly discussed at length among Izala themselves. This controversy is usually only found between Izala and Sufis. Bid'a is a concept that exists not only in the official name of the Izala organization, but it is also a basic element of its doctrine: fighting bid'a. This development concerning disagreement over bid'a was new to the Izala movement. The intra-Izala struggle on bid'a has an effect on its image as an anti-innovation movement. ${ }^{276}$ In the following, two out of the three internal Izalapublications are summarized. The focus is on the discourse of debate between the different factions.

\section{"Risalātān maftuhatāni ilā za ìm al-jamāa al-ismā ilìya..."}

This document was mentioned to me during an interview in Jos. The argument of my interviewee who is linked to the Kaduna group of the Izala movement was that only a few leaders among the two factions of the Izala movement write polemically. According to him, the 'ulama' of the Izala movement keep quiet on this issue. Most of these writings (debates) are composed by young scholars and other active members of both factions. ${ }^{277}$ The document is addressed to the actual Izala-leader in Jos - as the title explicitly shows. There is no indication about the publisher or the year of publication. In any case, the document is a collection of two letters which were not published. The first one was written on December 4, 2005, and the second one dates from 17 June

\footnotetext{
${ }^{275}$ Loimeier (1997a, 1997c) shows how the leaders of both Qādiriyya and Tijānīyya answered Gumi's polemical Arabic publication al-aqièda al-sabiha.

276 See the chapter "Izala and Innovation".

277 Interview in Jos with Sheikh Alhassan Said on 12 December 2006.
} 
2006. The document is 335 pages in length. It reflects the author's (linked with Izala Kaduna) message addressed to the actual leader of the Izala movement in Jos. The text of the two letters is documented. The author also comments on the reactions of two Izala-Jos-writers who are mentioned in the work. The whole work is structured as follows: the two letters addressed to the leader of the Jos-faction (Sheikh Jingir), a short overview on the history of the Izala movement and comments on the answer to the two letters. These two introductory chapters are followed by arguments and counterarguments. Issues like al-tahajjud (in Arabic: night prayers), amulets, etc. are introduced, and the matters are discussed according to classical scholars, then the answer of the Jos-faction of the Izala movement is elucidated; and finally, the counter-arguments are stated. The author relies on the two main publications of the Jos faction: that of Saleh Idris Muhammad (n.d.) and the other from Dalha Abubakar Abdallah (n.d). This strategy (issue, argument, and counter-argument) is linear until the end of the book.

The document starts by giving an overview of the issue of bid'a that has occurred among Muslims especially since the death of the Prophet. The author gives examples from history in order to document how rulers fought innovation in Islam in the past. He listed the first and second "Rightly-Guided-Caliphs" (Abū Bakr and 'Umar) and their struggle to maintain the guidelines of Islam as established by the Prophet. The struggle of the 'Ulamä' against new religious groups - like the Mu'tazilites (eighthtenth centuries, CE) - is mentioned by Dr. Jallo. Ibn Taymiyya, Ibn al-Qayyim, and al-Shatebi are among the scholars - according to the author - who fought and responded to innovations in Islam. Muhammad Ibn 'Abd al-Wahhāb, Usman Dan Fodio, and Abubakar Gumi also belong to this category. All of them contributed to the revival and purification of the sunna of the Prophet (Jallo n.d.: 1-7). From this historical overview, the author shifts to the Nigerian context, mentioning the appearance of haraka mudilla (in Arabic: delusive movement) under Ismaila Idris. This movement scarcely relies on the views of the founder and denies any advice or corrections (Jallo n.d.: 9). After the death of Sheikh Idris, he was succeeded by his murid (in Arabic: committed one) Sheikh Sani Yahya Jingir. Again, the use of a Sufi term to qualify the Izala movement leader shows the deepness of the intra-Izala movement conflict. The author concludes his introduction with the fact that he wrote the first letter to the leader of Jos in order to advise him and his followers. The reaction and denial of the first letter pushed him to write a second one, which was more detailed and explanatory than the first (Jallo n.d.: 9-12).

\section{The first letter, written on December 4, 2005}

Jallo addressed his statement to the rais al jamā'a al-ismátiliyya (leader of the group of Ismaila Idris), urging him to return to the sunna of the Prophet and to abstain from any form of deviation from Islam. This letter relies on a study of Sheikh Idris' cassettes and fatāwā which conform neither to the sunna nor to the Màlikī School of law 
- as Jallo claims. There are five points mentioned in the letter criticizing the founder's fatāw $\bar{a}$. The first and third points are on al-tahajjud, the second on qabdh, the fourth on circumcision, and the last point on jinn-possession.

The author blames the founder of Izala movement for lies and deviation from the Māliki School of law in many ways. According to him, Sheikh Idris rejects the claim that his followers pray with qabdh or hold amulets. Sheikh Idris denies the existence of $A b l a l-K i t a \bar{b}$ and refuses to eat their slaughtered animals or to get married to their daughters. He advises his followers to circumcise their children after they reach seven years of age. He rejects the claim that anybody can exorcise a possessed person from jinn. Jalo demonstrates that these fatāwa are not in conformity with the Mālikiyya and quoted several hadith indicating the opposite (Jallo n.d.: 14-27). Jallo closes his letter by warning the current leader of Izala movement and urging him to avoid bid'a, repent to Allah, and return to the sunna on the path of the pious predecessors. Furthermore, he declares his disposition for any religious debates: "I am ready - by the will of Allah - to meet you for any debate in order to clarify truth, revive the sunna of the Prophet, and eradicate satanic innovations. This meeting can happen in any place and at any time here in Jalango or any other suitable town" (Jallo n.d.: 27, translation $\mathrm{RbA})$.

\section{The second letter, written on June 17, 2006}

While the first letter is only a few pages in length, the second one is much longer and includes more details. The issues discussed are the same mentioned in the first letter. Jallo tries to legitimate the night prayers denied by Sheikh Idris. The author relies on different sources that mention this practice of the Prophet. Jallo did not restrict himself to argumentation and proof from the source (Qur'ān and sunna), but he goes a step further and attacks Sheikh Idris by locating him at the same level of Sufis and their practices:

You! Leader of the Ismā'iliyya sect! [the group around Sheikh Idris] You are on the same path as the Sufis because you invite people (in your fatwās and cassettes) to undertake bid' $a$ and other rubbish. Sufis in many cases disregard what is written in the Qur'ān and the sunna of the Prophet - PBUH - and follow their passion (al-bawā). This is exactly your case. You urged your muridin to advance the decision of what you call "Headquarters in Jos" instead of what is fixed in the sunna. By doing that, you led your murìdin to be like Abl al-Kitäb and Sufis in making their 'ulam $\vec{a}$ like their deity. You do that through denying what Allah allowed and by allowing what Allah denies. (Jallo n.d.: 47)

Jallo's strategy in his statement is to question the fatāwa or legal opinions of Sheikh Idris, then to compare Idris with Sufis and Abl al-Kitäb in falsifying their holy books. He quotes the classical work of the Tijāniyya, jawābir al-máāni, where it is required 
that the leader be followed and obeyed without any opposition, and he then compares this obedience to Sheikh Idris and his followers from the Jos faction (Jallo n.d.: 51).

Jallo uses the opportunity to remind the Jos leader of the history of the Izala movement. In a long (two pages in length) footnote on page fifty-three, he refers to the establishment of the Izala movement by enthusiastic people wanting to re-establish the sunna of the Prophet. He denies Sheikh Idris' taking of any leadership position apart from being the head of the 'ulama' Council. According to him, Sheikh Idris deviated from that path until he - as a person - became the norm and not the sunna (Jallo n.d.: 53-55). Jallo accuses Sheikh Idris of allowing aid group members to look after his personal security instead of performing prayers (Jallo n.d.: 61) and of banning his followers to listen to no other recorded preaching apart from his cassettes (Jallo n.d.: 63). The author criticizes the fact that Sheikh Idris' followers would not pray behind somebody who is not Izala. They will not even greet a non-Izala or go to his funeral. This behavior is different from the tradition of the al-salaf al-sălih since many ulama $\bar{a}^{\prime}$ accept differences and criticism (Jallo.65). Similar to the first letter, the author points out to the actual Izala leader that Sheikh Idris took people back on the path of Sufism and not on the path of Ablal-Sunna wa'l-Jamäa:

There is no doubt that what I mentioned to you is enough to confirm that Sheikh Ismaila Idris, the founder of the al-Jamäa al-Ismäciiliyya was the one who brought people to the pathway of Sufism by encouraging them to follow their passion and deviate from the Qur'ān and the sunna. (Jallo n.d.: 74-75)

The author reiterates in the very last footnote of this letter that he is preparing a new book entitled Ismaila Idris fi Mizann al-Shar' (Ismaila Idris at the Level of Legacy) in which he indicates the numerous mistakes and bid $a^{c}$ of the Izala movement founder.

The next part of the document consists of discussing the answers from the Jos group (Saleh Idris Muhammad and Dalha Abubakar). Jallo considers these responses to be not only full of mistakes (print, language, knowledge), but also as assertions to keep bid'a alive and to deviate from the Islamic sharía (Jallo n.d.: 77).

\section{Kalimät wajìza li-qam'sharr al-hasūd}

This booklet was published in 2006. On the front page is a picture of the Grand Mosque in Medina and the last page has the logo of the Izala movement: a palm tree and two crossing swords in the middle. This picture is overlayed by the full name of the organization at the top. Below that it reads "founded by Sheikh Ismaila Idris." Finally, it is indicated that the national headquarters of Izala movement are in Jos. A first interpretation of the cover of this booklet is that the author locates - as expected the Izala movement between the tradition of the Prophet that has its origin in Saudi Arabia, Mecca, and the tradition of Sheikh Idris who founded Izala movement in Jos. Identifying the Jos faction with its founder is a "marker" of its originality and loyalty 
to him. The sentence li-mu'așihīa al-Sheikh Ismaila Idris (established by Sheikh Idris) is visible at all Izala schools and institutions. The name of the founder is a sign of authenticity of the Jos faction. This faction of the Izala movement insists that the movement represents the tradition of the founder. It gives the organization not only a historical originality but also legitimacy among other groups. Even when it comes to official documents issued by the Izala movement in Jos, the name of the founder is always connected with Sheikh Idris' name.

The thirty-six-page booklet is subdivided into twenty chapters introduced by the author. After the first sentence, reserved for the praise Allah, Saleh Idris Muhammad quotes a verse from the Qur'ān (4:112) and a badith of the Prophet: [4:112] "anyone who commits an offence or a sin, and then throws the blame on to some innocent person, has burdened himself with deceit as well as flagrant sin" (Abdel Haleem translation of 2005). The hadith quoted by Sunan Abu Dawood (book 24, 14) states: "Allah sends the one who tells lies about a believer (Muslim) to hell, until he repents from what he said." From the beginning, the author shows that any Muslim risks committing a sin if he mistakenly blames an innocent of any fault. Also, anyone who slanders a believer (a Muslim) risks going to hell until he repents. This is a sign that the "defense" project of Sheikh Idris started with two major sources: The Qur'ān and sunna. He continued by defending the founder of Izala movement and proving that what has been written by Dr. Jallo is nothing but a rumor.

In the introduction, the author mentions that he had the letters addressed to the current leader of Izala movement in Jos. Saleh Idris Muhammad expected a kind of warning about the mistakes, but he was surprised by the level of subjectivity of Dr. Jallo's text. He says: "I observed through what I read in the "fire of jealousy," that there is antagonism and abhorrence in your heart. In fact, what you have written cannot in any sense damage the two Sheikhs. [Sheikh Idris and Sheikh Jingir]" (Saleh 2006: 2 , translation $\mathrm{RbA}$ ). To make the argument more plausible, the author makes use of Arabic poetry by emphasizing the issue of jealousy and illustrating the sentiments of envy and jealousy towards those who are in a higher position - the Izala founder and his successor in this case.

The first chapter of Saleh Idris bears the title "Sheikh Idris is on the side of truth": Here, the author explains how the founder of Izala movement relies only on the Qur'àn and the sunna of the Prophet and the path of al-salaf al-sălih including the four Imāms (four schools of law). He stresses that nobody can deny the importance of Imām Malik. He also defends Malik (d. 795) in front of al-Albānī (d. 1999) preferred by Jallo. "What divides us is that we invite people to learn about the Oneness of Allah and to avoid polytheism without restricting ourselves to the sayings of this or that person. And you work to destroy what we build; for instance, your invitation to people to keep amulets and prayers like every polytheist worshipping al-Tijānī or 'Abd al-Qādir” (Saleh 2006: 6).

The next nine chapters deal with the issue of bid'a. The main subject is the night prayers during Ramadan and its evidence in the sunna. The argument of the author is 
that the Prophet practiced it, but because he feared that people would make it into a sunna [norm, canon], he stopped doing it. The discussion deals with the controversy over the șalāt at-tarāwīh (in Arabic: a prayer after night prayers during Ramadan) considered to be sunna (optional but a recommended practice). Interestingly, it is in this context that Saleh Idris Muhammad accuses his opponent of practicing bid'a. First of all, he criticizes the call for prayers (Arabic: $a d h \bar{a} n$ ), inviting people enthusiastically to perform it, and to practice it only during a few days of Ramadan: "You start practicing this bid'a at midnight, five hours after finishing at-taräwīh (we don't deny its existence). Before you start, somebody can hear the voice of the muezzin with a new type of adhān: Prayers! Prayers! Prayers! And so on ... continuously. You! Jallo! Keep Allah in mind! You and those who are on your side! Where did you get this [prayer]?” (Saleh 2006: 6).

Saleh Idris Muhammad relies on the statements of the Prophet, especially regarding his practices in insisting that he [the Prophet] preferred prayers during Ramadan and advised people to perform them at home. Consider the sentence practicing bid'a is more difficult than practicing sunna (Saleh 2006: 12). The argument is to show that the Prophet considered the different categories of people (weak, sick, needy) before establishing any rules. The author adds that the practicing of this bid'a led to the fact that many Muslims cannot perform fajr-prayer (in Arabic: first Muslim obligatory prayer). If Muslims - according to Saleh - would restrict themselves to the tarāwi h̆prayers during Ramadan, which is recommended by the "pious predecessors", that would be much better for them. The so-called qiyäm (synonym for taräwi h prayers) as known by the al-salaf al-salith is practiced during the entire month of Ramadan. The new bid'a [night prayers] is only practiced during the last ten days of Ramadan - which is not in conformity with the practice of al-șabāba (the Prophet's Companions). One of the practices that is harshly criticized by the author is what he called al-adhān al-mukbtara' (the invented call for prayers).

In chapter eleven, a new topic is introduced and discussed, namely the qabd-sadlcontroversy. The author mentions that the Izala movement in Jos prefers praying sadl (in Arabic: hands alongside the body during the prayer) instead of qabd (in Arabic: right hand crossed over the left hand at the navel). He adds that followers of the Jos faction pray in both ways and that Sheikh Idris never forbade it. The argument of Saleh is that the Izala movement relies on strong sources confirming its preference for sadl over qabọd (Ibn al-Mundhir, al-Ḥasan and Ibrāhīm al-Nakh'î̀, Ibn al-'Arabī, al-Tabari are some sources mentioned by the author in order to give legitimacy to his argument).

The next subject, which is discussed in chapter twelve, concerns taslima, or the conclusion of prayers. The Izala Jos has a preference to perfrom one taslima instead of two. This practice is criticized by the Kaduna group. To show the strength of his argument, Saleh quotes three different ahädith ${ }^{278}$ (Arabic: pl. of hadith) showing that the

\footnotetext{
${ }^{278}$ The first hadith here is documented in the at-Tirmidhi hadith collection and corrected by al-Hakim (here Aisha narrated that the Prophet practiced only one taslima); the second one is to be found in Ibn
} 
Prophet completed his prayers with one taslima. Many 'ulamä' have not considered them ahādith weak or authentic but instead that the four "rightfully guided Caliphs" (the first four caliphs after the death of the Prophet) practiced only one taslima, which shows that it was a widespread practice. The argument of the author here is to prove that the issue of "closing" prayers is debated among Islamic scholars. He assumes that opponents of Sheikh Idris would never agree with him.

The next subject touched by Saleh concerns al-tamä'im (amulets). From the title, his position is clear: holding amulets is an act of polytheism. He addresses Jallo directly by saying: "You defend amulets although it is related to shirk" (Saleh 2006: 21). The fact that Imam Mālik allowed this practice (of holding amulets) does not mean that Mālik's statement is unquestionable. Saleh claims that his duty is to defend Sheikh Idris "who erased the state of polytheism in our country" (Saleh 2006: 23). Interestingly, the issue of following the Sufi path is raised again. Saleh accuses his opponents of being followers of Sufi brotherhoods. He adds that by criticizing Sheikh Idris, he [Jallo] is in fact praising his own deeds (fighting of polytheism and establishing tawhìd).

Can Izala members marry women who are abl al-kitäb, and can we eat their slaughtered animals? This is the focus of the next few chapters. The author confesses that the Qur'ān allows such a marriage. He mentions although this is a fact in the Islamic tradition, most of the schools of law (Mālikī, Shāfíīi, Hanbalī, Hanafī advised marrying a Muslim woman instead. In addition, Saleh brings up that contemporary abl alkitāb cannot be considered the same as the abl al-kitāb mentioned in the Qur'ān. To make this statement stronger, Saleh lists situations of conflict between Muslims and Christians from Nigeria (in Plateau, Kaduna, Taraba, and Adamawa) and raises the question: how can Muslims marry non-Muslims? (Saleh 2006: 28). He concludes this part of the booklet by warning Jallo against attacking Sheikh Idris and achieving fame by attacking the Izala founder and defender of the sunna. (Saleh 2006: 29).

The last two chapters deal with circumcision and communication with jinn. Concerning the first issue, Saleh defends the attitude of Sheikh Idris in delaying the circumcision of children until after seven years of age. He relies on two hadith confirming this practice and clarifies that Sheikh Idris spoke of karāha (in Arabic: abhorrence) and not tabrim (in Arabic: ban). He clarifies that many Islamic scholars reject circumcision on the eighth day after birth because this is a Jewish practice (Saleh 2006: 30). Concerning communication with jinn, only Prophets can communicate with them. Saleh opposes any person that claims the ability to see or speak to a spirit. He goes further by saying: "We will never believe in that [communication with a jinn] and we cannot pray behind you until you repent. We can only consider you as diviner and conjurer" (Saleh 2006: 31). The fact that the Prophet exorcised jinn from a human body belongs to his status as Prophet and nobody can perform the rite besides him. Saleh adds that the majority of diviners left their practices [communication with jinn], apart from Jallo and those who are on his side (Saleh 2006: 32).

Majah and narrated by Sahl Ibn Sa'd (one taslima is also documented here); finally the third source is a hadīth of Salma Ibn al-Akwa'; for more details see Saleh (2006: 16). 
The conclusion of the booklet takes the form of advice and warning. The author invites his opponents not to look for fame through criticizing Sheikh Idris and his successor. In an imperative tone, he warns them to leave jealousy and to stop attacking the two Izala movement founders. Like Jallo in his book, Saleh also declares himself ready for any debate at any place or time.

Through the comparison of both texts, one can find many similarities. The main sources of both authors are the Qur'ann, the sunna, and the tradition of Islamic scholars of Sunni Islam. The use of Arabic poetry (which has a long tradition even in pre-Islamic times, especially when it comes to defending or criticizing a person) is common amongst them. The issues of ignorance and knowledge of Islamic sources occur often. When it comes to the strategy used by both writers, they surprisingly use the concept of bid'a, which is controversial and dynamic. Almost the same vocabulary used to attack Sufism is now used by the two Izala writers themselves. The readiness for meeting - as a kind of test of knowledge or defense of arguments - is also a common element shared by both.

\subsubsection{Attempts at reconciliation}

When the conflict within the Izala movement occurred and the organization faced division at an early stage, there were attempts to reconcile leadership, undertaken by both insiders and outsiders. To many, the division of the Izala movement meant the failure of its reform programme and doctrine. Sheikh Abubakar Gumi thus attempted to reunify the two Izala factions as did the Governor of the Central Bank during the Babangida era. A delegation from Saudi Arabia came to Nigeria and invited the conflicting parties in the Izala movement to engage in dialogue. Even the Jamáat $A b l$ al-Sunna fi Gharb Ifriqiyya (the Society of Ahl al-Sunna of West Africa) based in Ghana sent delegates to Jos and invited the Izala representatives of Jos and Kaduna to engage in discussion. Dr. Ahmad Gumi (Sheikh Abubakar Gumi's son), who is based in Saudi Arabia and who comes to Nigeria every year for tafsir sessions during Ramadan, made an effort to re-unite the Izala movement. These attempts all failed. The reasons for these failures are interpreted by Izala members differently. The differences seem to be more complicated than expected and each faction maintains its own position. In absence of a compromise, especially concerning the role of leadership in the movement and the exact reasons for the conflict, reconciliation could not be achieved. Although the Izala movement today is still divided, there are voices arguing that reaching an agreement is only a matter of time. For others, the two Izala groups underwent different experiences since the split. This view is reflected by an informant saying: "I don't see reunification of the Izala movement in our life time! Not now! Maybe in the future!"279

${ }^{279}$ Name of the interviewee is confidential. 
Sheikh Abubakar Gumi tried during his lifetime to solve the problems in Izala movement. Being the father and the most respected authority in Izala movement, he invited the struggling leaders and attempted to help them reconcile. The fact that Sheikh Idris insisted on being the Izala movement leader and also the case of Alhaji Mai Gandu made the reunification impossible. There was also a delegation sent from Saudi Arabia with the aim (came to elect students from Nigeria) of unifying Izala movement but they failed as well, just as Dr. Ahmad Gumi did. He never came to me! He did it individually and failed. If he had come to me, I would be able to manage it and put things under control. ${ }^{280}$

Intensified attempts at unity within the Izala movement took place in 1991. The Governor of the Central Bank undertook two initiatives. It was recommended that Sheikh Idris and Alhaji Mai Gandu keep their positions under the same constitution. Differences between both made agreement impossible. During the same year, a delegation from Saudi Arabia tried to assist with reconciliation. Here an issue was raised by Sheikh Yusuf Sambo who heavily criticized Sheikh Idris. The founder of the Izala movement countered the issue by criticizing the involvement of politicians in the Izala movement and the enrichment of some members like Yakubu Musa Kafancan (Kaduna-faction) (Gurama 2000: 127-128). Again, the problems were not solved during this time even when Sheikh Idris intervened later that same year and invited all parties to a meeting in his house. The suggestion to impeach Sheikh Idris is the reason why this effort was unsuccessful (Gurama 2000: 134).

In 2006, the "Jamāât Ahl al-Sunna fi Gharb Ifrīqiyya" made an attempt to facilitate the reunification of the two Izala factions. The organization invited the actual leader Sheikh Jingir to Ghana to give a lecture. The leader of the Izala movement could not attend but sent a representative: Dalha Abubakar Abdallah. The Kaduna faction sent Sheikh Alhassan Said. These representatives discussed issues and another meeting at the headquarters in Jos was convened. Finally, representatives from Ghana came to Jos and engaged in discussions with the two Izala factions. This effort was not successful. ${ }^{281}$

Concerning the attempt made by Dr. Ahmad Gumi, it was no different from the others and failed at an early stage. On the first page of the JIBWIS Journal of Izala Jos, the title "Like father like son? Dr. Gumi's misconception" is meaningful (Gurum and Bello 2005: 21f). In 2004, he called on the two Izala groups to attempt reunification. The criticism of Dr. Gumi came from Jos. The Jos group blamed him of being politicized. According to them, he started talking to media even before talking to the Izala leaders. They accused him of not being an Izala member and of not being involved in any activity of the movement in or outside Nigeria. His plea was seen as "an intimidation and a provocation" (Gurum and Bello 2005: 21f). He was urged by the

\footnotetext{
${ }^{280}$ Interview on 6 and 9 March 2008 with Sheikh Abbas Hamid Abbas, the former leader of the Council of 'Ulamā' in Kano, Izala Jos branch.

${ }^{281}$ Interview in Lagos with Dalha Abubakar Abdallah, 18 February 2007.
} 
Jos group of Izala to curb his political ambitions: "Our request to him is to jettison the misconception of his sponsors and their political ambitions and to join us in the task of keeping alive the message of Allah and hadith of his last Prophet Muhammad (PBUH). The Izala National Headquarters is in Jos by the will of Allah. It has come to stay" (Gurum and Bello 2005: 22).

Sharp disagreement came especially from the Jos faction. They accused Dr. Gumi of being biased and of favoring the Kaduna faction over the Jossawa people. It was expected of Dr. Gumi to act like his father in his efforts to unify the two Izala groups. At an early stage people were interested in the new reconciliation project before they became disappointed and judged his attempt as a failure. The expectations were high at first, but the Izala people were soon disappointed. The reasons for the failure are given in the following statement:

Yes, he wanted to unify the organization and reconcile between the two groups. Well as you know, if someone wants to reconcile between two parties, then he should not prefer one and leave the other. He should invite all people, meet them and engage in discussion in order to know the truth ... isn't it like this? But when Sheikh Dr. Gumi came back to Nigeria; you know that relying on the Mālikì Law is one thing that divides us and the Kaduna faction. We say that the majority of people are ignorant and if we introduce this and that, people will not know how to worship Allah. So let us have only one standpoint. In the first year Sheikh Dr. Gumi said: "If a person abuses the madbbab, then is it proof that he is ignorant? Every person who abuses the Màlikī School is an ignorant person. This is what he said (Dr. Gumi). In that first year we supported him (Dr. Gumi) because we thought that he was following the way of his father Sheikh Abubakar Gumi in teaching people. Sheikh Abubakar Gumi was Mālikī and worked according the Mālikī School of Law. We saw that Dr. Gumi only followed the path of his father and he was closed to us. ${ }^{282}$

Dr. Gumi addressed the media regarding the problem of money, and provoked both groups by expressing the notion of takfir. Furthermore, he suggested removing the current leadership and replacing it with a new one:

In the second year he (Dr. Gumi) said that the Jamāat Izala movementt al-Bid'a Wa Iqamat as-Sunna should be one group under one leadership, but we should remove the current leaders in Jos and Kaduna and elect new ones. He said this on the radio. It was better to invite the leaders and discuss the issue with them instead of saying it openly on the radio. He came as a sultan accusing both groups of kufr and tried to unify us. But when the Izala movement was established, he was studying the modern sciences in the English language. He also said that they (faction of Izala movement in Jos) should bring him our

${ }^{282}$ Name of Interviewee, place and date are confidential. 
cars, close mosques and schools and we answered: "you were not the one who built these mosques or schools from your own money. The cars were purchased when you were in Mecca and you cannot have them now.”... So reconciliation cannot be like this. ${ }^{283}$

Dr. Gumi's comparison of the division of the Izala movement to abl ridda (in Arabic: people of apostasy) that should be fought according to the Qur'àn made reconciliation unachievable:

He also told people one day that it is allowed to kill us according to the Qur'ann... We are allowed to be killed since we are abl ridda - as he said. He relied on one Qur'ānic verse saying, "if two sects among believers are fighting, then reconcile between them and if one of the two refuses then fight the one that refuses (the reconciliation)" this is a proof for people to kill us. We said that this Qur'ānic verse was there when your father was alive, but (the father; Sheikh Gumi) never relied on it to kill the Kaduna-faction who refused reconciliation at that time. Your father left both parties do what they want because Allah is on the side of those who are in the right. That's it. If you want to kill us and do this and that, then we say: "we are ready to fight. This is the reason why he failed to bring reconciliation between us. He was inflexible in the end. He invited people to Kaduna and even the leader there didn't go: Abubakar Ikara didn't go; Yusuf Sambo didn't go; Mai Gandu didn't go. These are the leaders; the leader of the 'ulamá, administration and the deputy to the leader. They didn't attend the meeting. ${ }^{284}$

This is one version of why the attempt at the reconciliation of the Izala movement undertaken by Dr. Gumi failed. These attempts took place in 2004 and 2005 and both Izala factions boycotted it. During my field research in Nigeria it was not possible to meet Dr. Gumi or to listen to his point of view on the reconciliation project of the Izala movement that he suggested. The leader of the Council of 'ulam $\vec{a}$ in Katsina (Kaduna faction), Sheikh Yakubu Musa Kafancan, assures that although several reconciliation attempts failed to bring the Izala groups together, there are efforts still on the way. He argues that the intervention of the government in Izala affairs hindered its reunion. This was due to the Izala's boycott of a president who was not a Muslim. The Sheikh mentioned that the Izala's intervention was the reason why Obasanjo left his position as head of state. As a result of the work of the Izala movement, the late Umaru Yar'Adua then became president of Nigeria. ${ }^{285}$

${ }^{283}$ Name of Interviewee, place and date are confidential.

${ }^{284}$ Name of Interviewee, place and date are confidential.

${ }^{285}$ Interview with Sheikh Yakubu Musa Kafancan in Katsina, 12 March 2008. 



\section{The $\operatorname{shari}^{-} a$ debate of 1999}

The military rule of Sani Abacha in 1990 was one of the worst periods in Nigeria's modern history. The West African country suffered from repression, economic and political instability, ethnic conflicts, corruption, and human rights abuses. Abacha broke away from established democratic structures and turned Nigeria into an authoritarian state with no room for opposition or political activism (Ogbondah 2000: $231-242) .{ }^{286}$

After the unexpected death of Abacha on 8 June 1998, under unclear circumstances (see Maier 2000), General Abdulsalami became the head of state and promised to initiate the transition of Nigeria to a civilian government. In February 1999, presidential elections resulted in Olesegun Obasanjo becoming president. This was the starting point of the Fourth Republic - another attempt to democratize the federation. This transition was accompanied by a lot of expectations in and outside of Nigeria. Nigerians wished for a better life with higher living standards, for political and economic stability, and for the development of democratic structures and a more peaceful coexistence. Internationally, there was interest in reintegrating Nigeria into the world community after years of political isolation.

\footnotetext{
286 Apart of dissolving political parties and general assemblies, the Abacha's regime persecuted political opponents and activists (see Falola 1999: 196).
} 


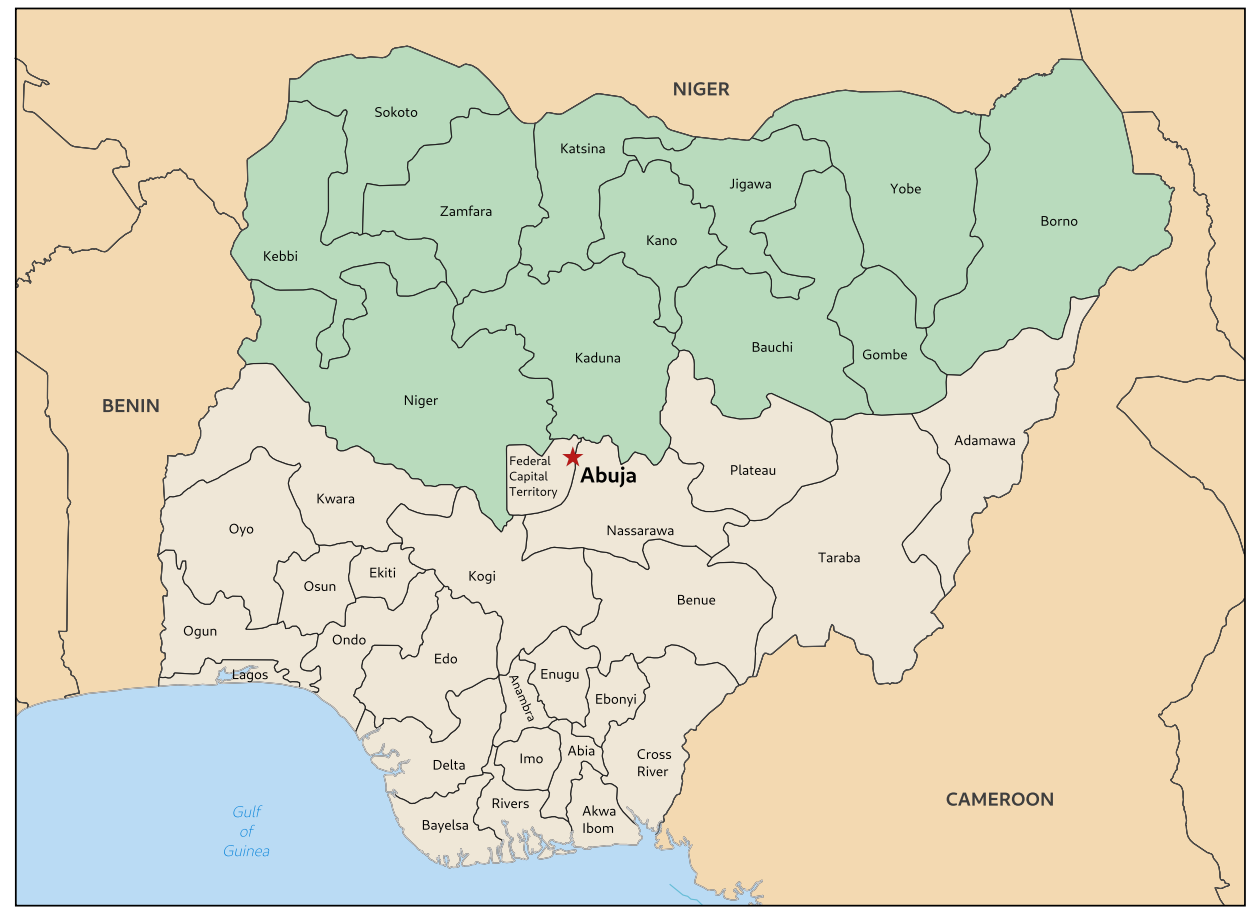

Map 2: States in Nigeria under Sharia law (green colored). ${ }^{287}$

The Fourth Republic faced big challenges at an early stage of its institutionalization. Nigeria is a rich country in terms of minerals. It is the largest exporter of petroleum in Africa and sixth worldwide. Nevertheless, the country suffers from mismanagement, poverty, corruption, ethnic and religious disturbances, and increasing criminality ( $\mathrm{Fa}$ tunde 2000: 74-76). Before all these issues can be solved, the constitution had to be revised and confirmed. This was part of the democratization process and a chance for political parties and Nigerian citizens to participate in the political debates of the federation.

The discussions over the 1999-constitution and the future of Nigeria were overshadowed by another debate: namely, the so-called shari' $a$-controversy. The decision of Ahmad Sani Yariman Bakura, Zamfara's democratically elected governor, to implement Islamic Criminal Law in his state in November of 1999 was reminiscent of sentiments in the 1970s and the political crises related to it. Zamfara's governor announced that Islamic law, $\operatorname{shari~}^{-} a$, would be fundamental in his state and that Muslims could rely on it in all aspects of their lives. This decision was later followed by another eleven states of the north that also announced $\operatorname{shari}^{-} a$ re-implementation.

${ }^{287}$ Drawn after http://constitutionnet.org/news/sharia-and-nigerian-constitution-strange-bedfellows (accessed 3/12/2019). 
This chapter analyzes the shari ${ }^{-} a$-issue and the way in which it was initiated. The following questions are central: What type of socio-political setting facilitated the re-implementation? Who were the major actors? Who contributed to the so-called shari ${ }^{-}$project and who opposed it? Which Islamic groups stood for shari $a$ and which resisted it? What was the position of the Izala movement in the controversy and what was its role in the re-implementation?

\subsection{Who implemented sharīa?}

The Houses of Representatives of the twelve northern states of Nigeria voted for the introduction of shari'a within a very short period of time. These states are Zamfara, Bauchi, Borno, Gombe, Jigawa, Kaduna, Kano, Katsina, Sokoto, Kebbi, Yobe, and Niger (see map 2). The Federal Republic of Nigeria consists of thirty-six states plus the Federal Territory of Abuja. The introduction of shari ${ }^{-} a$ took place legally according to the laws of the states. Philip Ostien summarizes the re-introduction of Islamic law and its implications for the north in the following five points:

1. The establishment of State Sharīa Courts and the implementation of sharīa in criminal and personal matters of Muslims. Appeal of judgement can be directed to the State Sharīa Court of Appeal.

2. The introduction of a new Sharīa Penal Code and Code Procedure for Muslims within the Sharīa Courts of Appeal.

3. Laws related to "social vices" and "un-Islamic behavior" (as Ostien calls them) including alcohol consumption, gambling, prostitution, and separation between the sexes.

4. Zamfara State and Kano State also introduced Public Complaints and AntiCorruption Commissions to fight corruption.

5. New institutions emerged from the shari' $a$ re-implementation, such as the State sharía commissions, Council of 'ulamä', zakät-board and hisba-board among others.

These measures were not consistent and differed from one state to another. They were applied only to Muslims in the shari'a states. These states still recognized the Nigerian constitution (see Ostien 2007: VIII).

Before the introduction of Islamic law, governors of the northern state constituted the so-called Shari'a Implementation Committees. These committees defined the needs and wishes of the people, consulted Islamic experts, and made suggestions for the future implementation of shari' $a$ (Ostien 2007: 3). ${ }^{288}$ These efforts implied that northern politicians were conscious about the importance of Islamic law for Nigerian

${ }^{288}$ Ostien indicates that the governors of the twelve northern Sharî́a states were concerned about not 
Muslims. From a historical perspective, $\operatorname{sharit}^{-} a$ was a problem both during colonial rule and after independence. It was (and still is) an important part of the Islamic identity of Nigerian Muslims. The governor of Zamfara State as well as all the other northern states insisted that such a step should be in conformity with the Nigerian federal constitution and in no way a deviation from it. The re-implementation of shari $a$ and particularly criminal law meant that these laws should be codified as it is mentioned in chapter 36(12) of the 1999-constitution:

Subject as otherwise provided by this constitution, a person shall not be convicted of a criminal offence unless that offence is defined and the penalty therefore prescribed in a written law; and in this subsection, a written law refers to an Act of the National Assembly or a law of a State, any subsidiary legislation or instrument under the provisions of a law. ${ }^{289}$

The shari'a re-implementation was part of the political campaign of Ahmed Sani before he was elected governor in January 1999. He promised to introduce Islamic law in his state and to promote Islam and Islamic values. In a speech at Ali Akilu Square in Gusau, the capital of Zamfara State, the governor declared, "it has become pertinent that we wake up from this sorry state of slumber and live up to our responsibility to the Almighty in order to avoid His curse" (Oduyoye 2000: 1). This decision was announced on October 27, 1999. The Sharia Penal Code came into operation on January $27,2000$.

Ahmed Sani appointed a committee of eighteen members to review existing laws and prepare the implementation. This procedure was still according to the Nigerian constitution. The Zamfara State commissioner of Justice, Hon. Attorney-General Ahmad Bello Mahmud, presented thirteen points of sharía re-instatement from the time it was merely an idea until its legalization. This procedure was equally a pattern among other northern states that were involved in the process of shari ${ }^{-} a$ re-implementation at that time. In a paper which Zamfara's Attorney-General presented in a seminar on shari'a in Jigawa in 2000, he clarified the basic steps followed in Zamfara State. The elected Sharia Committee identified Sec. 6 of the 1999-constitution as a legal framework for the implementation of shari' $a$. He defined the reasons behind the establishment of the law (curb social vices, moral decadence). Islamic law was codified (Sharia Penal Code, Penal Code Procedure, Sharīa Court of Appeal). The author also describes the policy of Zamfara State to fight corruption, organize zakät-collection, make dress code compulsory (bijäb for women), and regulate marriage and trade sectors, among others. The Commissioner insisted that such a process needs a transition phase during which people can be informed about shari ${ }^{-} a$. He also mentions obstacles that the re-

violating the constitution of the federation. "In most states it [Sharīa implementation] was done only after wide consultation".

289 Constitution of the Federal Republic of Nigeria (1999: 22). 
implementation could face, especially human rights laws, Christian opposition, and discussion regarding the general outline of the state (secular or not). ${ }^{290}$

The re-implementation of shari' $a$ in Zamfara State was part of the political campaign of a single governor. This decision was appreciated by the majority of Nigerian Muslims. They expected this change of laws as a solution to many of their problems. Ahmad Sani's campaign was successful twice and the shari' $a$-topic seems to have been a winning card during the elections in more than one state. ${ }^{291}$ The other northern states did nothing but answer the demands of the masses. Weimann observes that the example of re-implementation in Zamfara State which was followed by the other states led to a dilemma for some states' governors in the north. On the one hand, they (as Muslims governing states of predominantly Muslim inhabitants) were put under pressure to implement Islamic law; on the other hand, they had to compromise with the federal government and especially with the newly elected president's party, the PDP, that had commitments towards all Nigerians and the international community (Weimann 2010: 16)..$^{292}$

Most of the legal procedures of the re-implementation of $\operatorname{shari}^{-} a$ in the northern states took place during the years 2000 in Zamfara, Kano, Niger State, Kebbi, and Jigawa, and 2001 in Sokoto and Yobe (Peters 2003: 14). Although the northern states are predominantly Muslim, they are different in matters of laws, ethnic groups, political settings, and presence of non-Muslims. If the re-implementation in Zamfara State occurred quickly because the majority of the population are Muslims, then the situation in other states was much more complicated. In Kaduna, for instance, there is a large Christian population in that state and they felt threatened by the shari' $a$-reimplementation. Here we should mention that there are no reliable statistics about affiliation to any religion. This question was (and still is) a "taboo" even as recently as the 2006 population census. ${ }^{293}$ The state of Kaduna witnessed one of the first shari ${ }^{-} a$ -

\footnotetext{
${ }^{290}$ For Details see Ostien (2007: 171-176). The entire paper of Alh. Ahmed Bello Mahmud titled "On the adoption and Implementation of Sharīa Legal System in Zamfara State," presented at the JNI-sponsored seminar on Sharīa in Jigawa State, 6 July 2000, has been acquired. After mentioning the thirteen steps that took place in Zamfara throughout the re-implementation of Sharīa, the author insists on the necessity of dialogue between the proponents and opponents of Sharīa. He emphasizes that Sharī'a was introduced by law and that all Nigerian states should respect the wish of Muslims.

291 According to Weimann (2010: 17), the governor of Zamfara played the Sharīa-card in both 1999 and 2003 during the elections. Also, Governor I. Shekarau succeeded with a similar strategy in Kano state during the 2003 elections. For an overview on the "Shari'a-factor" in the 2003 elections in the federation see Kogelmann 2006: 256-274).

292 The governors of the People's Democratic Party (PDP) acting in the northern states were Umaru Musa Yar'Adua (Katsina State), Rabi'u Musa Kwankwaso (Kano State), Abdulkadir Kure (Niger State), Ahmed Makarfi (Kaduna State), and Ahmadu Adamu Mu'azu (Bauchi State).

${ }^{293}$ Statistics about religious affiliation is a political question in the country and can be misinterpreted. During the last census of 2006 this question was not raised. The last time the "question about religion" was part of the census dates back to 1952. Personally, I prefer not to give statistics about religion. For an attempt to give the percentage of Muslims in the twelve shari' $a$-states see Ostien (2007: xix).
} 
related riots between Muslims and Christians with casualties on both sides. ${ }^{294}$ The riots in Kaduna required the intervention of the then President of Nigeria Obasanjo, who condemned the occurrences and called for the reconciliation of the conflicting parties. After he travelled to the region, he appealed to the nation on March 2000 to deal with shari'a democratically and peacefully. ${ }^{295}$ Shari $a$ law became effective in Kaduna state in May 2001 (Peters 2003: 55).

The late Umaru Yar'adua, former Katsina State governor and the second president of the Forth Republic, implemented Islamic law in his state in August 2000. During the same year, this law was officially applied. ${ }^{296}$ Yar'adua addressed the people of his state indicating that shari'a needed the contribution of all and called on them to take responsibility: "all Muslims now bear a heavy responsibility for the need to contribute to the successful implementation of the legal code" (Oduyoye 2000: 95). In addition, he ensured that non-Muslims would not be affected by the new laws: "I assure adherents of other faiths that the government will guarantee the security of their lives and property. I assure them that none of their rights will be trampled on."297

In Kano, the center of Sufism in Nigeria and the commercial metropolis of the north, thousands of people celebrated the decision of the governor to implement shari'a in June 2000. ${ }^{298}$ A few months later (in November), Islamic law was legally approved. In December of the same year, consumption of alcohol in police stations, which is a federal institution, was banned. The institution of bisba was set up. ${ }^{299}$ Among other responsibilities, the hisba groups are charged with reminding Muslims to fulfill their religious obligations and impose sanctions on those people who ignore them (Peters 2003: 30). In order to fulfill the requirements of the shari ${ }^{-} a$ Project, Kano State established the so-called Sharīa Commission, zakät and Hubusi Commission (in Hausa: Islamic endowment) (Yusufari 2004).

Since June 2000, Islamic law has been in practice in Sokoto State. The first stoning case and three hand-amputation cases according to shari ${ }^{-} a$ law took place in 2001 (Peters 2003: 58-59). The case of Safiya Hussaini, a Muslim woman of the north, attracted the attention of the entire world. She was accused of adultery and sentenced to death by stoning by a Sharia Court in Sokoto. This case was extensively discussed nationally and even internationally. ${ }^{300}$ Although Hussaini was acquitted, a bitter contro-

\footnotetext{
${ }^{294}$ For a detailed description of the riots in Kaduna, see Danfulani, Ludwig and Ostien (2002: 74). The riots seem to have an ethnic aspect between the Muslims (Hausa) and Christians (Kajes and Katafs, for instance).

295 See Obasanjo's speech "President Olusegun Obasanjo's address to the nation on Sharia Crisis", 1 March 2000, https://nigeriaworld.com/feature/speech/obasanjo_sharia_address.html (2 May 2011).

296 Peters (2003: 57) registered cases of application of Islamic law in Katsina in November 2000 (lashes for consuming alcohol and unlawful sexual intercourse).

${ }^{297}$ See 'Nigeria's Katsina state adopts Sharīa' http://news.bbc.co.uk/1/hi/world/africa/860660.stm, Tuesday, 1 August 2000 (7 October 2004).

${ }^{298}$ See http://news.bbc.co.uk/1/hi/world/africa/798630.stm (7 October 2004).

${ }^{299}$ For details on hisba see Fwatshak (2003: 1-23).

300 For an extensive legal analysis of this case see Ostien 2007: Volume V "The Two Famous Cases"
} 
versy over the compatibility of human rights and $\operatorname{shari}^{-} a$, and equality between men and women under shari'a law arose.

The Governor of Niger State Abdul-Kadir Kure announced the implementation of a modified form of Islamic law in his state. He announced the re-implementation of Islamic law as a remedy for a corrupted political system. As was the case in Katsina, he guaranteed Christians that shari' $a$ would not affect them (Oduyoye 2000: 7). Niger State represents an exception among the other states of the north since it kept the $P e$ nal Code of 1960 and added Section $68 \mathrm{~A}$ for Islamic law and so called budüd-penalties (Peters 2003: 14).

In Jigawa State, $\operatorname{shari~}^{-} a$ was announced in August 2000, and many people travelled to Dutse, the state capital, in order to show their support of the re-implementation of Islamic law. Other inhabitants were sceptical about shari' $a$, preferred to stay indoors, and kept shops, hotels, and bars closed. ${ }^{301}$ Nevertheless, cases of burning down churches as well as violent acts between Muslims and Christians were documented in the territory of Jigawa State. ${ }^{302}$

In the north-east of the country, where Borno State is situated, $\operatorname{shari}^{-} a$ was implemented in 2000 and celebrated by the predominantly Muslim population. Christians are a minority in that region. The governor addressed the Christians in his state insisting that $\operatorname{shari}^{-} a$ is for the Muslims only. This statement was not considered by Christian authorities as a guarantee of their freedom to worship and of their safety. They reacted by performing prayers and fasting in protest of the planned law. ${ }^{303} \operatorname{Shari}^{-} a$ was officially introduced on June 1, 2001, although the Christians remained suspicious about the project (Peters 2003: 54). In the neighboring Yobe State, Islamic law was introduced in August 2000 and legally implemented two months later. The Sharia Penal Code became effective in April 2001 (Peters 2003: 58).

Bauchi state was the tenth state that implemented shari'a law on February 27, 2001. The protest from human rights organizations and Christians in the state failed to discourage shari' a law in that territory. As shari'a became legal in June 2001, approximately sixty-three judges were appointed to act as Sharia Court Judges. The $\operatorname{shari}^{-} a$ re-implementation caused a wave of riots in Bauchi State. Apart from burning places of worship, several people lost their lives, property was destroyed, and thousands were displaced (Peters 2003: 54).

Protests with slogans like "no shari $a$ " related to the shari ${ }^{-c}$ re-implementation in Gombe State led to violent acts at the end of May 2001 between Muslims and Christians in that region (Peters 2003: 54-55). Riots were registered in different towns of the state and caused rivalry between the two religious communities. The Anglican

[Safiya Hussaini and Amina Lawal]. Ostien provides excellent material on these cases including a translation of all proceedings of the process as well a statement of the lawyer who defended Hussaini. In addition, see Kalu (2003: 389-408).

$301 \mathrm{http}: / /$ news.bbc.co.uk/1/hi/world/africa/862662.stm (12 October 2004).

302 Peters (2003: 55) reports cases of burning of churches in the town of Gwaram related to tension between Christians and Muslims.

${ }^{303}$ http://news.bbc.co.uk/1/hi/world/africa/887355.stm (12 October 2004). 
archbishop of Gombe, Henry Ndukuba, described the shari' $a$ re-implementation as "a lie, a ploy and the greatest deceit" (Peters 2003: 54-55). He doubted that shari'a would be able to guarantee equality among people in his state.

In Kebbi State, shari' $a$ was introduced in July 2000 and was implemented by 1 December 2000. In January 2001, Muslim women in that state were asked to dress according to shari ${ }^{-} a$ law. In July of the same year, a young boy was accused of stealing money and was punished by amputating his hand. In September of that year, a man was sentenced to death by stoning over the sexual abuse of a seven-year-old child (Peters 2003: 54-55).

The re-implementation process of Islamic law differed from state to state. In most cases, it happened under the pressure of the Muslim population. Thus, most of the governors of the northern states re-implemented shari ${ }^{-} a$ as an answer to mass protest. Zamfara State was a pioneer in implementing sharía and its Penal Code was adapted by some states, while others used it as a template to develop their own codes. Seven states introduced Sharia Penal Codes (Bauchi, Kebbi, Jigawa, Kano, Zamfara, Yobe, and Sokoto) and Niger State preferred to keep the 1960 Penal Code with a particular section related to shari'a.

The northern Muslim states of Nigeria were not ready to re-implement Islamic law: They were truly surprised by the events that followed. The Penal Code varied from one state to the other. Islamic judges were not prepared to handle cases according to these recently implemented laws. There were no support institutions in place to facilitate the re-implementation process. Even the drafting of the Penal Code needed revision. In Zamfara State for instance, Peters speaks of a "hasty drafting" with "incorrect cross-references, incorrect and defective wording, omissions and contradictions" (Peters 2003: 45).

The shari ${ }^{-} a$ re-implementation raises several questions about its constitutionality and conformity with the laws of the federation. Laws in Nigeria like in any federal system are complex. The constitution is the most authoritative document defining regulations within the territory of the federation. In Nigeria, Islamic law was controversial during and after the colonial era. Islamic law was reduced to personal and family matters. The reintroduction of criminal law implicates its codification and integration of the law of the federal state in a written form as fixed in the 1999-constitution (see above).

According to Rudolph Peters the notion of "codification" in an Islamic context goes back to the early nineteenth century. He understands it as a measure of fixing that "... only the state determines what law is and that the state law is the highest form of law" (Peters 2002: 88). Nadjma Yassari, a jurist, observes that Islamic law was uncodified for more than a thousand years, although it was based on a collection of textbooks, annotations, and fatāwa (legal opinions). The process of codification took place through contact between Muslim societies and colonial powers. It was a sort of adaptation to the exigency of that period (Yassari 2004: 112). Codification of Islamic law first took place in the Ottoman Empire before it moved to other North African 
countries. The codification process varied from one contry to another. It changed the legal framework of shari'a from being "jurist law" to become "statuary law" - as Aharon Layish formulates it (see Layish 2004: 85-113). ${ }^{304}$

Apart from the codification of Islamic law, several questions were raised, especially as to whether this law violates the constitution of Nigeria. One of the controversies has to do with Section 10 of the 1999-constitution stating that "[t]he government of the Federation or of a State shall not adopt any religion as state religion.” This section was interpreted by many opponents of shari ${ }^{-} a$ in Nigeria as a confirmation that the form of the state is "secular." This means that none of the 36 Nigerian states can adopt a religiously inspired law (like shari' $a$ ) as a state law. On the contrary, supporters of the shari'a-project argue that the term "secular" was not mentioned in the constitution and the re-implementation was by no means a violation of it. Furthermore, Muslims mention that the constitution guarantees the right of religion and reinstituting Islamic law was part of that right defined in Section 38 (1):

Every Person shall be entitled to freedom of thought, conscience and religion, including freedom to change his religion or belief, and freedom (either alone or in community with others, and in public or private) to manifest and propagate his religion or belief in worship, teaching, practice and observance. ${ }^{305}$

There was an attempt to unify the Shari'a Penal Code initiated by the Centre of Islamic Legal Studies (CILS) at Ahmadu Bello University, Zaria. This was a project of "harmonization" of all Codes. ${ }^{306}$ Furthermore, its aim was to develop a judicial backdrop for the re-implementation in all Muslim states. At the same time, the project was meant to "enhance legal certainty and facilitate the training of judicial staff and police personnel" (Peters 2003: 45).

One of the biggest issues of the re-implementation was the legislative power between the states and the federation. According to Section 4 of the 1999 constitution, this legislative power was divided between both the state and the federation. Peters clarifies that "matters mentioned in the Exclusive Legislative List ... are exclusively federal matters, while matters mentioned in the Concurrent Legislative List can come under both the legislative power of the Federation and the legislative power of the states" (Peters 2003: 34). Other matters not mentioned in both lists are part of the state's legislation. This was exactly what happened with the introduction of Islamic

\footnotetext{
${ }^{304}$ Layish provides a good historical overview on Sharīa codification and how it took place and what kind of methods were applied. Furthermore, he gives an overview of the perception of codification by the 'ulamä'.

305 Constitution of the Federal Republic of Nigeria (1999).

306 Ostien (2007: 20-21) provides a good comparison of the "harmonized" Codes projects and the Penal Code of 1960. In fact, views on the CILS suggested Penal Codes are divided between "sceptics" (as Ostien calls them) who asked for reasons for such a project that may restrict shari' $a$ to what is written and those who perceive it as a chance to redraft and correct the introduced Penal Codes. The same volume provides a copy of this "harmonized Sharīa Penal Code" with annotations (Ostien 2007: 33-139).
} 
Criminal Law. Peters indicates that the Penal Code itself is unproblematic, but introducing shari ${ }^{-} a$ as a religiously inspired law was challenging (Peters 2003: 34).

\subsection{Proponents and opponents of the shari'a-project}

One may get the impression that all Muslims advocated the re-implementation of shari $a$ and that all Christians opposed it. This is, however, not the case. There were also Muslims who did not agree with the re-implementation, but who could not oppose it. This was the case among Muslim politicians, intellectuals, scholars, and even ordinary people.

Allen Christelow observes a loophole in the constitution of 1999 that led the twelve northern states to implement Islamic criminal law in addition to the existing personal and family law (Christelow 2002: 16). Christelow speaks of several other secondary factors that generated the Nigerian shari ${ }^{-}$-crisis. According to him, the feeling of insecurity within the population, social inequality, violence, and the absence of a well-structured state system are other factors behind the call for $\operatorname{shari}^{-} a$ (Christelow 2002: 18).

Muhammed Tabiu summarizes views of the opponents of shari $a$ and their argument for a possible violation of the constitution of 1999 in the following points: shari'a opponents thus questioned the legislative power of Zamfara as well as of the other northern states to reimplement Islamic criminal law. For these opponents, shari $^{-} a$ is reduced to personal matters and its use in criminal law is nothing but a violation of the constitution. Finally, they consider Nigeria to be a secular state according to Section 10 of the constitution (see Tabiu 2001: 6-7).

The jurist Bashir Yusuf Ibrahim analyzes the conformity of shari $a$ with the constitution. He mentions the establishment of the National Assembly and the State Houses of Assembly. Both have different fields of legislation fixed in the Exclusive Concurrent Legislative Lists mentioned above. The fact that Islamic Criminal Law was not mentioned in one of these lists became a matter for the states. This means that any state in the federation can introduce its own legislation or its own criminal law independently, regardless to whether this law is inspired by a particular religion or not (B. Y. Ibrahim 2003: 133). When it comes to the question of shari $a$ and human rights, Ibrahim understands penalties like death by stoning or the amputation of limbs and legs as a way to fight and reduce criminality in society and keep secure the life, property, and dignity of people. In addition, he reminds us that there is no paragraph in the constitution forbidding the death penalty (B. Y. Ibrahim 2003: 135).

Frieder Ludwig, a scholar of religion and an expert on Christian-Muslim relations in Nigeria, clarifies that the majority of Muslims (proponents) understand the shari'a re-implementation as "restitution of their rights" while, on the contrary, many Christians (opponents) consider Islamic law as "a step to Islamize Nigeria" (Ludwig 2008: 603). This opposition within the two camps is motivated by events like the two famous 
stoning cases of Amina Lawal and Safiya Hussaini as well as by discussions about the presidency of 2007, and whether the president should be a Muslim or a Christian. Ludwig quotes the reaction of the Anglican Archbishop Peter Akinalo when President Umaru Yar'Ardua, a Muslim and PDP (People's Democratic Party) candidate was elected as successor of Obasanjo as head of the state: "Oh! My God, a sharīa governor" (Ludwig 2008: 604). In the same vein, the reaction of the governor of Kano State, Ibrahim Shekarau, who showed his disappointment in 1999 when shari' $a$ was not introduced sooner (Ludwig 2008: 607). These two examples illustrate stereotypes of divided views on shari $^{-} a$ re-implementation.

\subsubsection{Proponents of $\operatorname{shari}^{-} a$}

In his article (2002) Danladi A. Mohammed from the Centre of Journalism Studies in Wales, seems to be among those who defended $\operatorname{shari}^{-} a$. His article is an answer to the prominent Islamic scholar and sharía critic, Sanusi Lamido Sanusi (whose views are discussed in the next chapter). Mohammed considers Sanusi to be one of those modernist scholars who was influenced by "orientalists." For him, Sanusi is a Marxist who developed personal views on sharīa that are far from reality. In addition, Mohammed goes further in reproaching Sanusi for being attracted to the views of the controversial Sudanese founder of the Republican Brothers, Mahmūd Muhammad Ṭha. ${ }^{307}$ As part of his defence of $\operatorname{shariv}^{-} a$, Mohammed goes even further when he categorizes Sanusi to be one among those secularist scholars (in the same category with Abdullahi Ahmad An-Na'im, a prominent Sudanese law expert living in the USA) who oppose 'ulama' and blame them of corruption and incompetence. According to Mohammed, Sanusi and the modernists want to reform Islam and change its rules. This step could be a danger to Islam since it leads to total secularization and abolition of the religion, which was the case in much of Christianity: "The problem is that Sanusi and other modernists before him wanted to change the rules so that Islam would be totally reformed like Christianity, leading to complete secularisation and the abolishing of Islam just as Christianity was abolished. This is clear from the writings of Mahmud Taha and his followers" (see Mohammed 2002). Mohammed concludes by attacking Sanusi Lamidu Sanusi and reproaches him for practicing propaganda, manipulating Islam, and even for selecting particular chapters from the Qur'ān and the sunna in order to confirm his point of view on the rejection of shari' a laws. Mohammed judges most secular reforms in the Islamic world as failed reforms. He cites the example of Turkey and the program of laicism imposed by Atatürk that failed to replace the long-lasting hegemony of the

\footnotetext{
307 Mahmūd Muhammad Ṭaha was executed in 1985 during the time of President Numeiri because of his controversial views on Islamic Qur'ān revelation. He made a differentiation between two types of revelations: one that happened before the hijra of the Prophet to Medina in 622 and one after that event. Taha believes that the Medinian-revealed Qur'ānic text should be understood in its historical context. This point of views was heavily criticized by Muslim scholars of that time. Danladi A. Mohammed reproaches Sanusi for being influenced by such views.
} 
Ottoman Empire. This attempt, like many others, led to a Westernization of Islamic societies and the adaptation of Western norms (Mohammed 2002).

Along the same lines of defending shari' $a$ re-implementation, the prominent Kaduna-based Islamic scholar, Muhammed Sanusi Gombe, argued that, compared to other religious communities in Nigeria, Muslims have been disadvantaged for many years. The Islamic scholar raises the points that for a long time Muslims tolerated nonMuslim norms like accepting Saturday as a public holiday instead of Friday. He even advocates extending shari' $a$ to the entire federation, not only in the north. The Islamic scholar Ali A. Mazrui also legitimizes the re-implementation of Islamic law in Nigeria. According to him, this law questions Western model(s) of law. Mazrui considers Nigeria a unique African state which offers an alternative to Western law traditions. $\mathrm{He}$ adds that $\operatorname{shari}^{-} a$ was a result of a critical reflection on existing Western norms. Furthermore, shari' $a$ led, according to Mazrui, to a pluralistic society and in no way to a repressed one (Danfulani, Ludwig and Ostien 2002: 89).

The current Izala leader in Jos, Sheikh Sani Yahya Jingir, fully supports the $\operatorname{shari}^{-} a$ project of 1999 and considers it an "embryo" in the process of growth. He expects this "embryo" to fully mature one day. He formulates it in the following:

Yes indeed! We also support that. We wanted $\operatorname{shari}^{-} a$ and consider it a janin (in Arabic: embryo) that will not be old in only one day, but will mature gradually. As Westerners [the British] came to us and criticized the shari' $a$ and reduced it until we couldn't do anything. Now we want to react to them. We have to react gradually and when shari'a becomes strong enough, then we will correct what we failed to correct before ..... ${ }^{308}$

This statement reflected the views of many Muslims in northern Nigeria who viewed Islamic law as a chance to unite Muslims. This unity was deeply affected by the colonial policy of reducing Islamic law to personal and family matters. The journalist Suleiman Shehu, who covered the $\operatorname{shari}^{-} a$-related event for Radio Kaduna in 1999, speaks about the feelings of Muslims at the gathering of Gusau, in the capital of Zamfara State when the announcement to reinstate Islamic law was made. During the re-implementation ceremonies, Shehu, who was deeply moved, confessed that he has never seen a comparable crowd of people before. For him, the project unified Islamic groups despite doctrinal differences:

... the implementation of $\operatorname{shar}^{-}$' $a$ involves the religion of Islam, you have all the groups, I mean the sects, the groups under Islamic organisations coming together to give their input. They were called by the state government to come and give their input because you have the 'ulama' of the Sufis, you have 'ulama' in the Izala movement, you have 'ulama' in the other groups. So they called for unity. For the implementation of $\operatorname{shari}^{-} a$ is basically teaching of the Prophet

${ }^{308}$ Interview with the Izala movement-leader in Jos in his office, 28 February 2007. 
Muhammad - peace be upon him. That was, I think, the basis under which the groups were unified. ${ }^{309}$

The acceptance and support of shari' $a$ happened at the level of the 'ulama's as well as the grassroots level where expectations were enormous. Ordinary Muslims were enthusiastic and interpreted shari' $a$ as a solution to their problems in the country. Suleiman Shehu added that in most cases, people at the grassroots level are "guided by the "ulama" and consider them their "mentors." Although many Muslims at the grassroots level are ignorant about what shari'a really means and what kinds of challenges and changes can occur because of it, they trusted their religious leaders who supported shari ${ }^{-} a$. A part from this support, ordinary Muslims also expected $\operatorname{shari}^{-} a$ to improve their economic and social conditions:

Yes, $\operatorname{shari}^{-} a$ is the way. It will work for us... maybe it is the cradle of the years: years of campaign, years of call, years of... you know; people, you know, aspiration towards having a shari'a government. So whatever that will entail, they will say rudely, "oh yes, we are ok." 310

\subsubsection{Opponents of the re-implementation of Islamic law}

It seems that most Muslim groups, except the Shī'ites under the leadership of Ibraheem Zakzaky (see Suleiman 2005), welcomed the shari ${ }^{-} a$ reimplementation without reservation. Zakzaky and his group - known as the Muslim Brothers and labelled as Shi' ites by the majority of Muslims - opposed the reimplementation. In a lecture given at Bayero University in Kano in December 1999, Zakzaky tried to clarify his position towards shari ${ }^{-} a$. After defining the word shari ${ }^{-} a$, he classified Islamic countries practicing shari'a into three major categories: first, "traditional" ones that have applied the shari' $a$ for a long time and that were hardly colonized by Western colonialists; second, countries that applied shari ${ }^{-} a$ only partially: these countries have been colonized and after independence, they started practicing a "post colonial system of democracy"; and finally, countries where the shari' $a$ is absolute and where an Islamic revolution may have taken place (al-Zakzaky 1999: 8).

After discussing the examples of Pakistan, Sudan, and Iran, Zakzaky came to the conclusion that shari' $a$ was successful only in Iran because it is part and parcel of an Islamic state. He concludes that the success of a full shari' $a$ implementation is only guaranteed within a system of government which is "purely Islamic." Concerning Ni-

\footnotetext{
309 Interview with Suleiman Shehu in Arewa House, Kaduna, 16 January 2007.

${ }^{310}$ Interview with Suleiman Shehu in Arewa House, Kaduna, 16 January 2007. Suleiman Shehu mentions that these expectations were demonstrated by the masses that came to Gussau to support Ahmad Sani Yariman Bakura in his undertaking of instituting of Islamic law. While many people estimate the number of people would reach one million, the journalist speaks of approximately 800,000.
} 
geria, Zakzaky predicted two conflicts that would coincide with implementation of the shari ${ }^{-} a$ : One conflict would be with the constitution which would claim superiority over the shari $a$ and would, therefore, place the shari' $a$ under its control and regulations (al-Zakzaky 1999: 13). The other conflict would be with shari' $a$ itself which, as the Law of Almighty God, claims superiority over all laws and therefore cannot accept the supremacy of the Nigerian constitution (al-Zakzaky 1999: 13). Al-Zakzaky concludes by saying that the application of shari' $a$ under a government system which is not Islamic will subject it (shari'a) to "restrictions, manipulations and possible abuses” (al-Zakzaky 1999: 15).

One of the most prominent independent Islamic scholars in northern Nigeria is Sanusi Lamidu Sanusi. He is an economist by profession and, since 2009, the Governor of the Central Bank of Nigeria. He is also an expert on Islam in northern Nigeria and has published extensively in that field. ${ }^{311}$ Sanusi criticizes aspects of the application of budīd in general and aspects of particular questions related to the law as it is practiced in Nigeria. In the case of Amina Lawal, a woman accused of unlawful sexual intercourse (Arabic: $z i n \bar{a}$ ) and sentenced to death by a Sharīa Court in Katsina, Sanusi questioned the background of Islamic law in Nigeria, its relevance in the sources (Mukbtasssar Sidi Khalill), and how Islamic judges dealt with the adultery case of Amina Lawal (Sanusi 2002: 4-7). Sanusi emphasizes that the rights given to Safiya Hussaini - another prominent zina case in Nigeria - to revoke her confession of committing $z i n \bar{a}$ - she was initially sentenced to death in Sokoto State and then released were not given to Amina Lawal by the Upper Sharia Court in Futuna, Katsina (2002: 4). According to the Sanusi, the standard book of Islamic Mãlikī law used in Nigeria, Mukhtasssar Sìdī Khalīl, considers personal confession evidence for a hadd-penalty "unless it was withdrawn in any manner whatsoever" (Sanusi 2002: 4). This means that the accused has the right to annul his or her statement. ${ }^{312}$ Amina's lawyers appealed her penalty since her rights were not considered by the judges who sentenced her to death. Amina's lawyers presented in fact twelve points against the judgement. Among others, the court did not explain to Amina what ziñ $\bar{a}$ is and which implications she faced in the case of adultery (see more details in Babaji and Dankofa 2003: 123).

\footnotetext{
${ }^{311}$ Most of Sanusi Lamido Sanusi's articles and views were published on the Internet platform http:// www.gamji.com/sanusi/sanusi.htm. According to personal observation he published extensively until the year 2005 on that platform. After that period he seems to have been more engaged in Economics as Risk Manager at the United Bank of Africa before he was appointed as governor of the Central Bank of Nigeria in June 2009. See also Taschner 2006). Taschner makes that same observation that Sanusi published a lot in the field of Islam in Nigeria until 2005. She counted eighty publications of his accessible on http://www.gamji.com as well as on http://www.nigerdeltacongress.com (deactivated, but accessible via archive.org).

312 In some Islamic schools of law it is required that the accused person confess/repent committing adultery in front of four different judges. In the Maliki and Shafi Schools, a single confession is required; for more details see El Baradie (1983: 105).
} 
Sanusi goes further by explaining the issue of pregnancy if the woman is divorced or widowed and how the different Islamic schools of law deal with such a situation. In Mukbtasssar Sìdi Khalìl the waiting period, called 'idda, of a widow or a divorced woman lasts from two to five years, although in the different schools of law, it is debatable how long it should last (see Bossaller 2004). If a woman gives birth to a child outside that period of time, then it is a case of zin $\bar{a}$ (adultery) confirmed through pregnancy. According to Sanusi, the situation under the Mâlikiyya is much more complicated. A woman risks a hạdd-penalty under the Mālikī School of Law when she falls pregnant in the fifth month of the fifth year after the death of her husband or the divorce (in case she did not marry again). ${ }^{313}$ Many Islamic scholars deal with this regulation sceptically since neither Allah nor his Prophet fixed a waiting period of five years, as Sanusi points out. Even Imam Mālik did not release a clear statement on the waiting period. ${ }^{314}$ In the case of Amina Lawal, she gave birth two years after her divorce. Sanusi reminds us that she should not be condemned to death because of pregnancy or giving birth as long as there is no consensus on the waiting period or on pregnancy as evidence for $z i n \bar{a}$ (Sanusi 2002: 7). Sanusi formulates it clearly that "Adultery is committed every day, but only those against whom admissible proof is established are punished by law" (Sanusi 2004: 216).

This viewpoint claims that shari ${ }^{-} a$ is an ideal project for equality and justice among Muslims. In fact, such promises in a country like Nigeria in which political and ethnic tensions are high are far from becoming reality. Sanusi looks at the $\operatorname{shari}^{-} a$ reimplementation from a social perspective rather than strictly within a religious and legal discourse. Sanusi perceives the shari ${ }^{-} a$-debate in his country to be a political issue in which religion is ideologically misused. He speaks of "political violence" leading to a split in society (Sanusi 2004: 218). The recently implemented law cannot guarantee justice among Muslims. Women especially are disadvantaged in the project:

... at the level of ideology it holds that the discourse exhibits tendencies of political violence toward the weaker segments of society. Slicing through the opacy or religious jargon and propaganda, social critics highlight the reality that the poor and the women seem to be on the receiving end of harsh punishments, and that the intensification of the process of religious revival is accompanied by a deepening of contradictions in the social formation. (Sanusi 2004: 218)

In most cases, Islamic law has been applied only to the poor. Politicians and the wealthy enjoy the possibility of escaping such a law. The ideal of social justice under shari ${ }^{-} a$ was thus far from being realized. Sanusi observes that implementation of Islamic law provokes a clash of law, i.e. a clash between Islamic traditional norms and Western laws.

\footnotetext{
313 All Islamic Schools of Law fixed the period "six lunar months" for the birth of a baby within the institution of wedlock. In the case of a divorced or widowed woman falling pregnant before these six months, then it can be interpreted as a case of zinā; for more details see Sanusi (2002: 5).

${ }^{314}$ Imam Mālik spoke of 4, 5, 6 and even 7 years, see Sanusi (2002: 6).
} 
Many Muslims do not agree with Western concepts of equality in the society if they do not conform to Islamic norms.

A slave is not the equal of a free born, a woman is not equal to a man and a nonMuslim is not equal to a Muslim, even though clear guidelines are given for compassionate treatment of women and slaves, and the protection of certain non-Muslims (who pay the special poll-tax, the jizya). (Sanusi 2004: 220)

Sanusi argues that shari'a understood as a way of life is unproblematic for Nigerian Muslims. The situation became more critical when it came to the application of certain aspects of Islamic law. Shari'a was criticized because religious discourse was used to achieve ideological and political goals (among others) through the state in order to legitimize an existing economical, political, and social system of inequality (Sanusi 2004: 224).

Sanusi considers the issue of justice to be a central aspect of shari $a$. He asks how amputation can be applied to those who steal a goat and not for corrupt civil servants of the state. He questions how justice can be proven in the case of adultery, especially when "different standards" are applied to men and women? Is that religion or ideology? Sanusi sees more ideology behind shari' $a$ than religion (Sanusi 2004: 226). Furthermore, he draws attention to other Islamic countries that have implemented reforms in their law tradition and accommodated legislation to the needs of people without deviating from the tradition. He insists that such a step in Nigeria is more than needed - especially a critical approach towards religion. There is a need to differentiate between those who consciously manipulate religion for ideological objectives and those who tend to establish the law of God (Sanusi 2004: 227-230).

In a paper on the relationship between politics and Islam, Sanusi warns those politicians who use Islam in northern Nigeria to achieve political goals. He argues that the duty of all Muslims is to oppose such "spoiled" politics (Sanusi n.d.). For such politicians, shari' $a$ should not only be a sign of harsh sentences and sanctions, but also a way to establish social justice and improve the economic situation of Nigerians. Politicians should not use shari ${ }^{-} a$ to conceal their own corruption, abuse of office, and nepotism (Sanusi 1999: 8).

Lamidu Sanusi was not the only Nigerian scholar who maintained a critical view of shari $\bar{i}^{-} a$. These critical scholars stress that there is no enforcement in Islamic faith ( $l \bar{a}$ ikrāha fíd-dinn, Qur'ān 2:256) and that the newly implemented Islamic criminal law cannot favor Muslims or protect them: "... shari' $a$ rule leaves Muslims helpless before it” (Sanneh 2003: 240). A Muslim lawyer from Kano, Suleman Kumo, observes that Islamic judges of shari'a courts are incompetent and corrupt, and abuse of office is common in such courts. These judges, argues Kumo, would even "fail a simple character test" (Sanneh 2003: 240, quoted in Maier 2000: 178).

Lamin Sanneh mentions a Muslim from the north named Mohammed Sani who, in front of other Muslims in August 2000, openly criticized Zamfara's Governor and 
his campaign to re-implement sharīa law. These critiques were based on the argument that the implementation had more to do with politics than with religion. According to Mohammed Sani, shari' $a$ comes from Allah and not from the governor. ${ }^{315}$ On February21, 2000, anti-sharía demonstrations took place in protest against the introduction of shari ${ }^{-} a$. Several other riots between Muslims and Christians resulting in loss of properties and lives on both sides happened in the following days. Several mosques and churches were destroyed. Shari ${ }^{-} a$ appears to be a violent dispute between Christians and Muslims in the federation, to say the least. ${ }^{316}$ Christians and human rights organizations in Nigeria interpret shari' $a$ as a violation of the constitution and of human rights and see in it a danger for the peaceful coexistence in a multiethnic and multi-religious state like Nigeria. Frieder Ludwig speaks of a sort of "fundamentalismthesis" developed and introduced to the debates by shari'a opponents. As an example, Ludwig mentions the chairman of the Christian Association of Nigeria (CAN) in Edo State, Archbishop Patrick Ekpu, who points to the OIC controversy and warns against Islamic Fundamentalism in northern Nigeria sponsored by Arabic countries (Ludwig 2001: 266). There are some other opponents of sharía who consider it a "second jihād," comparing it to the successful movements of Usman Dan Fodio and the Islamization of northern Nigeria during the nineteenth century (Ludwig 2001: 267).

In an International Religious Freedom Report, the US Department of State judges the re-implementation of Islamic Criminal Law in Nigeria as an abuse of religious freedom and a cause for interreligious violence. The report states that Christians in the north were not affected by shari' $a$, especially in Zamfara State, where Christian minorities were only minimally influenced. Segregation of both sexes in public transport, ban of alcohol, dress codes, closing shops on Fridays, and banning cinemas can be considered aspects of such an impact of shari' $a$ on Christians. The US Department of State report points out that the law of the federation does not allow any religious discrimination, but the Nothern States of Nigeria violated that law and discriminated against religious minorities. ${ }^{317}$

\subsubsection{The Federal Government, the federal states, the 'ulamä' and grassroots' positions on $\operatorname{shari}^{-} a$ re-implementation}

For the Federal Government of $1999^{318}$ under president Obasanjo the shari' $a$ re-implementation was a precarious matter. The democratic process of Nigeria and the transition to democracy was appreciated on the national as well as on the international level.

\footnotetext{
315 Sanneh (2003: 240) based on his statement and criticism towards the Governor of Zamfara, Mohammed Sani was arrested and jailed for four months. He was accused of violating the loyalty of Zamfara State.

316 For more details on the Sharī'a related riots, see J. Ibrahim (2002) and Danfulani (2005: 13-38).

${ }^{317}$ See US Department of State (2001): International Religious Freedom Report, Nigeria. Released by the Bureau of Democracy, Human Rights, and Labor.

318 For an overview on the transition to democracy in Nigeria see Fatunde (2000: 74-91).
} 
The debates related to Islamic law seemed to divide the country on a religious basis. The president, a born again Yoruba Christian from the south, had no choice but to reduce the tension in the country. At a very early stage of the re-implementation there was no official statement from the government for supporting or opposing shari ${ }^{-} a$. This is understandable since religion in Nigeria is a complicated issue. The intervention of President Obasanjo was related to the riots of Kaduna in 2000 and the heavy tension between Muslims and Christians in that state. Travelling in person to that area, President Obasanjo was shocked by the consequences arising from clashes related to the shari'a controversy. He expressed his deep disappointment and wondered during his visit on February 27, 2000, if it was really the same Kaduna that he knew from earlier times: "Are you people sure this is Kaduna? Can this be Nigeria? Are we still in Nigeria at all? I don't think people who did this could have done it for any religion. I don't think they did this for any religion" (quoted in Danfulani 2005: 24).

He indicated that such acts cannot be grounded in religion. In an official address to the nation on 1 March 2000, he described the Kaduna events as "barbarism." Obasanjo spoke of "the worst incident of blood-letting" since the Civil War in Nigeria. He called on all parties involved in the conflicts to engage in dialogue and reconciliation, and to respect the federal constitution that guarantees freedom of religion. Furthermore, he added that the National Council of States would hold a meeting to discuss the security situation as well as the re-implementation of shari $a$ in the northern states and its constitutionality:

The Council also reviewed the remote and immediate causes of the disturbances, and noted that the Penal Code currently in force in the northern States is substantially based on Sharia Law, with the modifications that imprisonment is substituted in place of amputation of limbs, as punishment for stealing, and also as punishment for adultery, instead of stoning to death. The Council noted that these modifications are consistent with the human rights principles enshrined in our Constitution, and considered the punishments adequate in the circumstances. The Council unanimously agreed that all States that have recently adopted Sharia Law should in the meantime revert to the status quo ante. That is, Sharia, as practiced in Penal Code, continues to be practiced by all States concerned. The Council urges all Nigerians to remain calm and lawabiding. Provocative and inciting utterances will not be tolerated. This position by the Council is a triumph of love of fatherland, triumph of maturity and sustenance of security of the nation and preservation of our corporate existence. There can be no winners in the destructions, all Nigerians are losers. And in peace and cessation of destructions of life and property, all Nigerians are winners. But to respect the feeling of one another and to hasten the process of reconciliation, there is no victory to be celebrated and no loss to be mourned. ${ }^{319}$

319 President Olusegun Obasanjo's address to the nation on Sharīa crisis, March 1, 2000; see the entire speech at http://nigeriaworld.com/feature/speech/obasanjo_sharia_address.html (29 May 2011). 
The official position of the then president and his government was moderate in order not to divide the country into pro- and anti-shari'a people - unlike Obasanjo's opinion on shari ${ }^{-} a$ few months ago before the Kaduna riot. ${ }^{320}$ The Nigerian Inter-Religious Council (NIREC), ${ }^{321}$ established in September 1999, received the support of the president to work for more peaceful coexistence between Muslims and Christians in the country. NIREC recommended that leaders from both religions should take on the duty of quelling tensions, and members of the two different religious communities should converge.

The federal government in Nigeria has no choice but to reconcile conflicting parties over shari' $a$. At the state level, the situation was different. In the southern part of Nigeria shari ${ }^{-} a$ was present in the media but was not problematic since Muslims are in the minority there. Nevertheless, Muslims among the Yoruba for instance find other ways to practice shari' $a$ and have established Independent shari' $a$ panels as shown by Abdulfattah Makinde (2007). In the northern part of the country, the governors were influenced by the masses; public pressure seemed to be higher than they realized. Ahmad Sani Yariman Bakura was elected in 1999 and re-elected in 2003 because he implemented Islamic law. The shari'a factor was also used in Kano by the former governor Ibrahim Shekarau who achieved two mandates (2003 and 2007) before he became one of the leading candidates for the Nigerian presidential elections of 2011.

In Kaduna, the situation was more complicated and the House of Assembly was divided among Christians who opposed the re-implementation and Muslims who favored it. Governor Makarfi (PDP) seemed to have won the elections of 2003 because of his moderate view on shari $a$ re-implementation, unlike his rival candidate (ANPP) who played the shari $a$ card and advocated full implementation (Ludwig 2008: 626). Ludwig also shows how Gombe State chose the way of dialogue between Muslims and Christians in order to reduce tensions and religious clashes (like the riots of 2000 and 2001). This was achieved by establishing a legal system made of Sharia Courts, Customary Courts, and a Magistrate Court (Ludwig 2008: 627). Even though Ahmadu Mu'azu, governor of Bauchi State (1999-2007), was among the first governors who started to implement shari $a$ in the north, he insisted on patience especially in stoning cases and admonished shari $a$ judges in adultery cases who sentenced pregnant divorced women to death by stoning (Ludwig 2008: 629). ${ }^{322}$ Concerning the home state of the late President of Nigeria (2007-2010) and former governor of the state (1999-2007) Umaru Yar' Adua, Katsina, Christians seem to have ongoing problems

\footnotetext{
${ }^{320}$ During a visit to the USA, when he was asked about the issue of shari ' $a$, President Obasanjo answered; "The government simply wished the Sharīa cancer would disappear into thin air."; quoted in Danfulani (2005: 23). When the Zamfara governor called for the inauguration of Sharía, Obasanjo called on the Vice-president, ministers, governors and emirs to boycott the event, see Danfulani (2005: 52).

${ }^{321}$ For history and information on this institution see https://web.archive.org/web/20120624221240/ http://www.nirecng.org/history.html.

322 This event happened in 2002 and was quoted by Ludwig from Vanguard of 19 December 2002

"Mu’azu Cautions Sharīa judges."
} 
with education within the state, and their children face difficulties at the secondary school level in finding a school. In addition, Christian TV-programs and the building of churches seemed to be among the difficulties expressed by representatives of the Christian Association of Nigeria in that state. The re-implementation in Katsina happened under pressure and the governor practiced a moderate policy that in part assisted with pilgrimages of Muslims and Christians to Mecca and Jerusalem, respectively. Also, the dialogue between both religious communities was supported by the state. ${ }^{323}$

The 'ulamä' are important actors in the shari' $a$-project. In northern Nigeria, Islamic scholars are well established and highly respected in society. They have the duty of guiding the umma (Muslim community) when it comes to religious matters. 'ulama are those who have access to the "sources." The Nigerian historian Haruna Wakili considers the role of 'ulama $\vec{a}$ during the period immediately before the re-implementation of the shari'a in 1999 as "neutral" (Wakili 2009: 3). After the re-implementation of the shari' $a$, they became more involved in politics. They insisted on more "sanitization" of society and politics in the north in order to achieve the goals of shari $a$ re-implementation (Wakili 2009: 7).

During the elections of 2007, Islamic scholars were fully involved in calling Muslims to register in the elections and vote for leaders who were "credible, honest and God-fearing." Although shari' $a$ did not play an important role during the elections of 2007 (as it was the case during the elections of 2003) (see Kogelmann 2006: 256-274), Wakili states that "anyone who campaigned against the shari'a in the states surely would not be voted for" (Wakili 2009: 8). He confirms that the 'ulamä' are not a homogeneous group in the north and their political orientation was not uniform. Wakili cites the example of Kano, where 'ulam $\vec{a}$ ' were divided between those who supported governor Shekarau and campaigned for him and those who opposed him. Many Islamic scholars used mosques, seminars, and public lectures to mobilize Muslims to vote for him. Other 'ulamä), like the Qādiriyya and Tijāniyya leaders (Sheikh Qaribullah Kabara and Sheikh Kalifa Rabi'u, respectively) as well as Salafiyya leaders, campaigned against Shekarau (Wakili 2009: 9).

Ordinary Muslims consider 'ulamā' to be their spiritual guides. For many Muslims, Shari' $a$ was a chance for changes in many aspects of life. Most ordinary Muslims do not really know much about the implication of $\operatorname{shari}^{-} a$ and what it really means. If you ask about shari' $a$ and how people understand it, in many cases you may get answers like:

Wonderful! Great achievement and we love it!... the implementation was a great achievement for a country like Nigeria. We never dreamed of having sharía so soon, so even if it is not fully implemented, it has made a great impact in our

\footnotetext{
${ }^{323}$ Ludwig mentions the establishment of a "Christian Pilgrims Welfare Board" in the State as well a Muslim-Christian Forum in order to promote peace and dialogue among Muslims and Christians (Ludwig 2008: 630-1).
} 
hearts and those of our children. For the younger ones to know about the presence of $\operatorname{shari}^{-} a$ is a great thing. ${ }^{324}$

Or statements such as:

I so much loved it. It is a great achievement, though there are certain restrictions, but I am happy about it and I hope that in the future we will be able to have a caliphate that rules according to Islamic law. ${ }^{325}$

The shari'a application appealed to the feelings of Muslims. Shari'a was introduced as a solution to their problems and was expected to bring change in many directions, especially economically and socially. Many see in $\operatorname{shari}^{-} a$ an answer to corruption, political mismanagement, and social injustice. The re-implementation of Islamic law was valued as an alternative and an option for a better life. This may or may not be true, but Muslims generally follow their 'ulama's' in matters of the re-implementation of Islamic law:

The grassroots! You know, the grassroots normally have been guided by these: the 'ulamä' and others, because the basis of the followers is the grassroots. And some of them see the 'ulamä' as their mentors who tell them what is supposed to be even when they don't have knowledge. There is a lot of ignorance, of course in the grassroots, but then when something appeals (sic) their social condition, their economical (sic) condition, they welcome it. For instance, they welcome a situation by which you will say: "Ok!" There is no more selling alcohol in the entire society; because it is their children, it is their people and brothers and sisters that ... or you say that have a situation where you can abolish prostitution, I mean brothels and other places where you find this, or gambling; all these social vices. Of course the grassroots will proudly welcome that because most of the crimes are related to these people. So this is the base for that, there was a massive support for $\operatorname{shari}^{-} a$ implementation. ${ }^{326}$

This statement is confirmed by several ordinary (male) Nigerian Muslims interviewed throughout my fieldwork in 2007 and 2008. According to them, neither their social status nor their sex played a substantial role in their opinions and the re-implementation of the shari' $a$ was positively perceived at the grassroots level. Thus, the question has to be asked whether the re-implementation of the shari' $a$ was really a challenge for Nigerian Muslims? I wonder whether we can confirm or disconfirm the statements of

\footnotetext{
${ }^{324}$ Interview with J. M. on 15 March 2008 in Jos; J.M. is one among six women interviewed in Jos by R.M., by a female research assistant. For the reason of protecting the interviewees as well as the name of the assistant, I prefer not to write the full names.

325 Interview in Jos with H.H. on 5 March 2008.

326 Interview with Suleiman Shehu, Journalist, 16 January 2007, Kaduna.
} 
these Muslims. Did alcohol outlets, brothels and places of gambling really disappear completely from northern Nigeria? Or did they only disappear from the public sphere? To what extent was the success of shari ${ }^{-} a$ so clear that even Islamic organizations claim to have been behind the re-implementation project? In the following chapter, the Izala movement's contribution to and perception of shari' $a$ are introduced.

\subsection{Izala's contribution to the re-implementation of Islamic law}

The re-implementation of shari ${ }^{-} a$ turned out to be a very successful initiative at least in the beginning. Thus, many different groups claimed to be the initiator of the reimplementation of Islamic law in northern Nigeria. But there are different voices and opinions on this issue. One main and highly powerful opponent seemed to be the Federal Government as the statement of Sheikh Jingir, leader of the Izala movement's council of 'ulama' in Jos shows:

As Ahmad Sani Bakura introduced his project to implement shari ${ }^{-} a$, he asked all people to come to Gusau. We accepted his invitation because at that time it was a problem between him and the government. Some Islamic organizations refused to go because they feared the government. We went there and so did the other faction of our organization [Kaduna branch] as well as the Sufis. All supported the programme. We saw what the issue was: who accepted what is called Islam and who refused it. We came together because of politics. In the matter of politics we came together, but concerning fatwās and theological questions we are like before: different. ${ }^{327}$

According to Sheikh Jingir, only the two Izala branches and the Sufi brotherhoods answered the call of the Governor of Zamfara State. But this shows that the most powerful Islamic groups and organizations of northern Nigeria supported the shari ${ }^{-} a$ project from the very beginning. The doctrinal and ideological differences became less important; politics dominated the support of Ahmad Sani's project. Sheikh Jingir did not talk about the initiator of the re-implementation. One gets the impression that it was Ahmad Sani himself who started the project of re-introducing shari' $a$, but according to Ustadh Nasir Abdulmuhy, a prominent representative of the Izala movement Jos-faction, maintained that it was his organization which initiated the entire project: "The Izala movement was among the first who called for the implementation of shari' $a$ and thank God, the Governor of Zamfara, was the first who listened to the call of the Izala movement and practiced shari ${ }^{-} a$. This is one of the good things done by the jamäa." 328

\footnotetext{
327 Interview with the Izala-leader in Jos in his office, 28 February 2007.

${ }^{328}$ Interview with Ustaz Nasir Abdulmuhyi, Jos, 5 December 2006, in his office.
} 
This statement gives the impression that the main actor of the shari'a project was the Jos faction of the Izala movement. The future governor of Zamfara State only reacted "to the call of Izala movement." The leader of the Izala movement in Lagos, Dalha Abubakar Abdallah, affiliated with the Jos branch, went even further:

As we launched into our preaching, he [Ahmad Sani] came to the lecture and spoke of his wish to become a governor: "I promise you - my organization; our organization - that if you elect me as governor, then I will implement the Islamic shari ${ }^{-} a$. I will do it because this organization [Izala movement] taught and linked us to what is useful for us and through it we understood that the religion is Islam, and shari'a is the best thing in life that a human being can reach. Shari'a is the way of satisfaction of Allah. If you elect me now as Zamfara's Governor, I will apply shari a' !" ... After that he became governor of Zamfara. The late Sheikh Idris sent him a letter saying: "I thank Allah for you, but I want to remind you that you promised Allah to apply his shari' $a$ and since you have the opportunity to do it, then hurry up. It is a treasure that should not be delayed." 329

According to Dalha Abubakar Abdallah, Ahmed Sani looked actively for the support of the Izala movement during his political campaign. He promised the Izala movement to re-implement Islamic law if he was successful and became governor. That means it was a political deal between the politician Ahmed Sani and the religious organization Izala. Implicitly, the Izala movement supported him during the election campaign. This becomes clear when the leader of the Izala movement Jos reminded him to fulfill his promise after he was elected governor of Zamfara State. Finally, Ahmed Sani delivered and implemented full sharía. Some leading personalities of the Izala movement even claim him as a member of the movement. Nuhu Tahiru Tajuddeen, head of the administrative council in Kaduna State (Jos branch), said that Ahmed Sani "confessed in front of the Izala movement, but before that we didn't know him. As he confessed then we considered him an Izala man. He confessed himself." ${ }^{330}$ This view is also shared by Abdurrahman Lawal Adoro, a former Izala movement leader from Katsina. When questioned whether the Izala movement was the first organization to call for shari'a the scholar attested that Ahmad Sani Yariman Bakura was an "Izala man." 331

These statements show that a number of leaders in the Jos-faction claim that their organization was the initiator of the shari'a project. It is impossible to prove such statements because many Muslims in Nigeria identified themselves with shari ${ }^{-} a$, not just the Izala movement. The leader of Jamāat Tajdìd al-Islām (in Arabic: Society of Re-

\footnotetext{
329 Interview with Dalha Abubakar Abdallah, Lagos, 18 February 2007.

${ }^{330}$ Interview with Nuhu Tahiru Tajuddeen, January 10, 2007 in his office, the centre of Islamic Development, Imam Road, Tudun Wada, Zaria.

331 Interview in Katsina with Abdurrahman Lawal Adoro, 12 March 2008, his Office at the University of Katsina, dept of Arabic Studies.
} 
vival of Islam - JTI), Sheikh Abubakar Mujahid, pointed out that the re-implementation of shari' $a$ in Nigeria was achieved through the contributions of many groups: the Izala movement, Sufis, JTI and others: "the tariqa and Izala movement played the role of sensitizing people. (The) people of the umma took care of the legal aspect, and JTI tried to find answers to issues like corruption; the zakāt (issue) of course was our (task) and we looked how to collect zakāt." 332

Sani Modibbo, former Izala national secretary, confirms that implementing shari ${ }^{-} a$ or transforming Nigeria into an Islamic state was not the initial agenda of the Izala movement. Instead, the movement was determined to fight bid' $a$ and Sufism more than anything else. ${ }^{333}$ This point of view is backed up by Sue O'Brien in her article on shari' $a$ in Nigeria. She writes that the Izala movement was neither the first group that called people to apply Islamic law nor the one that monopolized its application: "Les réformistes d'inspiration Wahhābite connu sous le nom d'Izala movement et leurs nombreuses branches, dont certaines reçoivent des financements Saoudien, n'ont pas été les premiers à réclamer la charia, pas plus qu'ils n'ont monopolisé son application, au profit des principales confréries soufis, la Qādiriyya et la Tijāniyya” (O’Brien 2007 : 48).

The leader of the Qãdiriyya brotherhood in Kano, Sheikh Qaribullah Kabara, confirms that the shari ${ }^{-} a$ project was the product of many different initiatives:

Nobody can come out and say that he is going to apply Islamic shari'a and could not find help. When they came with that, the Qaadiriyya was one among many Islamic groups that promoted the project and helped in its establishment. We had a meeting at that time. I think the government started calling for shari'a only after we called for it here, in this house. ${ }^{334}$

The Maiduguri-based scholar and member of Borno's council of 'ulamä', Sheikh Muhammad Ali Gabshiya, observes that if Izala movement was the leading organization behind the sharía re-implementation then Sufis would not have compromised. The scholar points to a statement of Sheikh Tahiru Bauchi, the prominent Tijāniyya leader, who once said that voting for a Christian is better than voting for an Izala man. That is why Sheikh Muhammad Ali Gobshiya cannot imagine that the Izala movement was the initiator of shari'a in the north. ${ }^{335}$

From the Tijāniyya point of view, it is also unimaginable that the Izala movement was the driving force responsible for the re-implementation. Alhaji Abubakar Imam, a Tijāni and registrar of the sharía Court of Appeal in Maiduguri, points out that Sheikh Ibrahim Saleh and Tijāniyya leaders started very early on to write about the

\footnotetext{
332 Interview with Sheikh Abubakar Mujahid, Zaria, 5 January 2007.

333 Interview in Jos, 28 February 2007.

${ }^{334}$ Interview with the leader of the Qādiriyya Sufi brotherhood in Kano, House of the Qādiriyya,

2 January 2007.

${ }^{335}$ Interview with Sheikh Muhammad Ali Gabshiya, 5 March 2008.
} 
necessity to re-implement Islamic law. Apart from the several lectures he gave on that matter Sheikh Ibrahim Saleh published a book on the budüd-punishments. Alhaji Imam confirms that the Tijāniyya were the first ones who called for shari'a. He confesses that this call may have been misunderstood and confused with criminal law. He clarifies that shari ${ }^{-} a$ cannot be limited to corporal punishment for certain offences. It is more than that and has to do with education, economy, and civil service. Shari ${ }^{-} a$, according to him, is to be found everywhere. ${ }^{336}$

The re-implementation of shari $a$ appears to be a concretization of Izala's worldview of an Islamic society based on the Qur'ān and the tradition of the Prophet. The dawa of the Izala movement consists of educating people about their religion and guiding them to follow the right way to become good Muslims. The Izala movement insists on education at every stage of life and establishes schools and mosques to provide its adherents with education. The Izala movement calls on women to wear bijäab. It stands for separation of the sexes in all aspects of life. The Izala movement propagates an ideal society without alcohol, gambling, or prostitution. It encourages knowledge about Islam and the Arabic language. It gives an important status to religious scholars. The organization demands the application of Islamic law in all its aspects and according to the elementary sources of the Islamic religion. The Izala movement regards itself as protector of Islam and Muslims. The organization makes efforts to defend Islamic interests. In Plateau State, which is not a shari'a state, the Izala movement, for instance, succeeded in changing the times of public administration and schools on Fridays in order to allow Muslims to go perform their prayers. Since colonial times, only Sunday is a work-free day in Nigeria. ${ }^{337}$ At the beginning of 2007, the design of Nigerian currency was changed. The Jos-faction of the Izala movement realized that the new Naira bills were without Arabic scripture, so they sent letter to the President of the Federation, Obasanjo, on February 27, 2007, expressing their "displeasure and total rejection of the removal of Arabic inscription.” The Izala movement indicates that removing Arabic as an identity marker of Muslims may be against human rights and "endangers the interest of some Nigerians on the basis of their religion." "338

After Islamic law was introduced, the Izala movement was adamant that all aspects of it should be applied in the northern states. Weimann mentions the example of Bauchi State and its governor Mu'azu who was visited by a delegation from the

\footnotetext{
336 Interview with Alhaji Abubakar Imām on 5 March 2008 in his office, Sharīa Court of Appeal, Maiduguri.

337 In an informal discussion on December 13, 2006 with Professor Muslih T. Yahya in Jos, from the department of Arabic and Islamic Studies, the scholar mentions that Izala movement in Jos makes efforts that Muslims can stop working by 12.30 in order to go for Friday prayers and come back by 2.30 p.m. 338 This open letter entitled "Memo to Mr. President Chief Olesegun Obasanjo G.C.F.R. on the recent removal of Arabic inscription from the Nigerian currency notes," published in the Daily Trust of 27 February 2007. A copy of this letter was send to the Senate President, The Speaker of the House of Representatives, the Deputy Senate President, The Central Bank Governor, The Sultan of Sokoto, the Emirs (Kano, Borno, Zazzau, Katsina, and Ilorin), the Etsu Nupe, and the AARE Musulmi of Yorubaland.
} 
Izala movement urging him to rush in applying Islamic criminal judgements. Aware of the implications of the law in a mixed state like Bauchi, the governor responded that it is the shari'a commission's duty to deal with that (Weimann 2010: 49-50). Also in Jigawa State the Izala movement warned Ibrahim Turaki, governor of the state from 1999 until 2007, that he should not stop the "divine" law of shari'a from being enforced in a stoning case from 2002 (Weimann 2010: 57). Weimann's explanation of the enthusiasm of the Izala movement in the shari'a project sounds very plausible: "The Yan Izala movement ... was quick to espouse the project on the basis of common interests" (Weimann 2010: 57). Weimann emphasizes that this interest does not mean an effort for an Islamic state, but rather a kind of establishment of a particular vision of an Islamic "way of life" according to sharīa (Weimann 2010: 57). ${ }^{339}$

Historically, the Izala movement was founded to fight un-Islamic innovations (bida) in Nigeria. There were social, political, and economic changes that occurred in the federation during the last years that brought Muslims to reflect on their relationship and doctrinal differences in the entire country. Events like ethno-religious clashes in several parts of the north, debates related to the constitution, and the elections in the federation (the leader should be a Christian or a Muslim) are just a few examples. In times of clashes the borders between religious groups within the same community all but disappear. For Christians in Nigeria, all Muslims re-implemented shari $a$ law and there is no difference between the Izala movement, Sufis or Shī'a groups. The sharī'a project was an opportunity for Muslims to think about common objectives and leave internal debates aside. The re-implementation of Islamic law was an opportunity for the Izala movement to "conquer" more space in a religious field dominated by the Sufi brotherhoods. The shari ${ }^{-} a$ project was also a chance for the Izala movement to gain recognition of its ideology based on the Qur'ān and the sunna. The Izala movement and shari' $a$ can be placed side by side since both are calling for the "sanitization" of Islam and offer a solution to Muslims in all aspects of life. If the Izala movement perceived shari'a positively and of its many leaders claim that the organization was directly and indirectly behind the re-implementation, then what about the Izala-Sufi brotherhood relationship? Did sharía law put an end to the long struggle between the Izala movement and the two major Sufi brotherhoods in northern Nigeria? Did sharí'a re-implementation really bring change with it? Did it unify the Muslim umma?

\footnotetext{
${ }^{339}$ In a discussion on sharī $a$-debates in Jos on 18 December 2006 with Professor Musa Gaiya, a church historian and religion expert in Nigeria, the scholar spoke of "Islamization of the society" rather than an Islamic state.
} 


\subsection{The Izala movement, Sufis and $\operatorname{sbar}^{-} a$ law: A chance for reconciliation?}

After the long-lasting conflict between Sheikh Gumi and the Nigerian Sufi brotherhoods which eventually developed into clashes between Sufis and the Izala movement, internal issues had been increasingly weakening the organization since the beginning of the 1990s. The division of the organization between Jos and Kaduna affected the image of the movement and its credibility amongst Muslims in matters of leadership. Most (if not all) Izala movement leaders confess that the division of the movement has nothing to do with 'aqida but rather with orientation within the organization: are 'ulam $\vec{a}$ 'at the top of the Izala movement or not?

In dealing with internal problems, the Izala movement was concerned with education, preaching, and convincing Muslims in northern Nigeria of being the authentic "Izala" founded by Sheikh I. Idris. This new orientation in the Izala movement allowed Muslims to speak of different groups within the Izala movement: that of Jos connected with the founder and known for its strictness compared to other Islamic groups; and that of Kaduna, which is more compromising when it comes to Sufis and other Muslims; and even another group of the Izala movement members who did not belong to either of these two branches. ${ }^{340}$ The concentration on their own problems led to a reduction of the tension between the Izala movement and the Sufis. Violent clashes that were the case in the 1970s and 1980s decreased. Clashes over religious space in mosques and in the public sphere changed into verbal struggles. Nevertheless, differences still existed, and borders became more visible (different schools, mosques, activities, interests).

The re-implementation of $\operatorname{shari}^{-} a$ was neither planned nor prepared. It was motivated by politics and part of an electoral campaign of one single governor with the intention "to gain popular support and to secure his own political survival developed into a chain reaction throughout the predominantly Muslim-inhabited northern states of Nigeria" (Kogelmann 2006: 257-258). Sufis, the Izala movement, and many other Islamic groups had no choice but to cooperate. The northern governors called all Muslims to contribute to the shari'a project and asked the 'ulam $\vec{a}^{-}$to set up the outlines of such an undertaking. No religious leader should be excluded except if he is against shari ${ }^{-} a$. Opposing shari $a$ means opposing Islam and that can be related to social isolation. shari ${ }^{-} a$ - as shown above - is an identity marker for Muslims in northern Nigeria. It was seen as a chance for Islamic law after years of oppression. Sharīa

\footnotetext{
340 Professor Musa Gaiya speaks of an Izala movement A, B, and even C. Under the third group he categorizes those Izala movement members who studied abroad and adapted a modern model for society, $18^{\text {th }}$ December 2006. Under this third wing of the Izala movement, I consider those members who are still related to both groups without taking part in one group or the other. Among them is Alhaji Abba Damburno, from Jos, who considered himself a father to both the Jos and Kaduna factions (interview on 24 December 2006).
} 
was related to change and reform of society. $\operatorname{Shari}^{-} a$ became a unifying issue despite the heterogeneity of the Nigerian society and existence of other religious groups in the shari'a states.

The re-implementation processes of $\operatorname{shari}^{-} a$ was initiated by establishing $\operatorname{shari}^{-} a$ Implementation committees in each state with the duty to advise and prepare a report with the recommendation of the best way to implement Islamic law and how to codify it in conformity with the federal constitution. In these committees, we find Sufis (Qādiriyya, Tijāniyya, etc.), Emirs, Salafis, Izala, independent scholars, JTI, Islamic judges, professors, and other experts. ${ }^{341}$ At a later stage the different institutions that emerged from shari' $a$ re-implementation like the zakat-board, the council of 'ulam $\bar{a}$, or bisba boards were comprised of representatives from different religious groups.

For some scholars the re-implementation was more of a political than a religious project. Sheikh Khaled Aliyu, an independent scholar based in Jos observes that the re-implementation was politically colored. He speaks of a "marriage" (Arabic: zawāj) between Izala movement and politicians. The Izala movement was looking for higher influence and politicians for more voters. That is why the Izala movement was ready to compromise. ${ }^{342}$ This is almost congruent with Sheikh Muhammad Haris, an established Tijāniyya leader in Jos, who saw a lot of fitna behind the sharía re-implementation. The leader confirms that verbal attacks between Sufis and the Izala movement still happen. ${ }^{343}$ Some other scholars are more optimistic, like Sheikh Alhassan Said, who sees an advantage in the re-implementation; mainly, the possibility of a dialogue among the different Islamic groups: "Those who implemented shari'a brought all of us together. We meet, speak and negotiate." ${ }^{44}$

A few scholars have indicated mixed feelings towards $\operatorname{shari}^{-} a$ and reunification of Muslims including the Izala movement and Sufis. Ustaz Ibrahim Ahmad Makari, a Tijānī scholar based in Zaria, indicates that there was great hope linked to the $\operatorname{shari}^{-}$'a project. According to him, hundreds of gatherings (Arabic: majälis) were set up as a result of the re-implementation of the $\operatorname{shari}^{-} a$. He expected that the project could result in reforms within the Muslim society in the north, but there was a lot of politics behind sharìa: "Intafā al-ḩamās" (in Arabic: enthusiasm is over) - this is how he phrased it. He mentioned that self-interest hindered the project from achieving its goals. In Kano, for example, he views those who implemented Islamic law as selective and did it for their own advantage. In addition, in the Council of 'ulamà' in Nigeria, although Tijāniyya, Qādiriyya, and Salafiyya are represented, the representatives of these groups were far from solving the problems of ordinary people - as Ustaz Makari points out. In Zamfara State, identity was defined through a long beard and a particu-

\footnotetext{
${ }^{341}$ For more details on the structures of these committees and their reports in Bauchi, Zamfara, and Kebbi states as well for all memoranda related to the reimplementation-process see Ostien (2007, Vol. II).

${ }^{342}$ Interview in Jos on 14 December 2006.

${ }^{343}$ Interview Jos, 3 December 2006.

${ }^{344}$ Interview in with the Izala movement Sheikh who is affiliated to the Kaduna branch, 12 December 2006.
} 
lar type of dress. Makari concludes that maybe five percent of shari'a was realistically achieved because politicians mainly appealed to the emotions of the people. Makari ensured that the future would be more promising since there is an agenda to unify all Muslims in northern Nigeria.

Regardless of whether the Izala movement initiated the shari'a project or another Islamic group was responsible for the most dramatic change in the judicial system of Nigeria since independence, in the aftermath of the re-implementation, the conflict between the Izala movement and the Sufi brotherhoods seemed to have been relegated to the background. Whether this challenge can be understood as reconciliation between the Izala movement and Sufi remains an open question. 



\section{Conclusion}

The major objective of this study was to look at the development of the Izala movement since its foundation in the late 1970s, to consider the crisis of the movement in the 1980s and 1990s as well as efforts at reconciliation in the 2000s. Of particular interest was the re-implementation of the shari' $a$ in Nigeria in the early 2000s due to the fact that the application of Islamic law was an integral part of the movement's ideology. This aspect of the development of the Izala movement has not been studied before, since the re-implementation of Islamic law is a very recent development in the history of northern Nigeria.

The Izala-Sufi controversy has also taken on another dimension. The violent clashes between the Izala movement and the Sufis that occurred during the 1970s and 1980s were scaled down since the early 1990s. This development can be explained by the fact that the Izala movement was concentrated on its own internal problems (division, struggle for leadership, financial issues) on the one hand, and it underwent a process of institutionalization and became a well-established and recognized Islamic organization in northern Nigeria, on the other. However, it is debatable as to whether the series of violent clashes between Christians and Muslims since the re-implementation of Islamic law in 1999 led to a reduction of tensions within the Muslim community or not; that is, whether intra-religious conflicts were replaced by inter-religious ones. 
In order to understand the current religious situation, it is necessary to go back to the history of Islam and Christianity in Nigeria. A historical overview on Islam serves as a background for what is going on today: Nigeria with its current borders did not exist until the coming of the British. In the $19^{\text {th }}$ century, the Sokoto Caliphate dominated the Muslim north with its emirates. In the southern region, African Traditional Religions as well as Christianity dominated the religious landscape. For many Muslims of the north, the colonial domination, despite indirect rule, was a period of massive intervention in Islamic affairs. The fact that the highly developed and, in Muslim eyes, holy Islamic law enjoyed only the same status as other "native laws and customs" was regarded as a devaluation of shari ${ }^{-} a$. In addition, the reform of certain aspects of the Islamic legal tradition according to Western norms and values was also an important event. This led to a conflict of laws that continued until the re-implementation of shari'a in 1999. The Izala movement emerged from an intra-Islamic conflict between Sheikh Gumi and the Sufis. The organization became the major actor amongst reformoriented Nigerian Muslims since it attacked the well-established tradition of Sufis in the country. Sufism in the Nigerian context also means that certain religious traditions were affiliated with political and economic power. The Qàdiriyya Sufi brotherhood was traditionally linked to the house of Usman dan Fodio whereas the Tijāniyya Sufibrotherhood challenged this position for a long time.

The ostensible reason for the establishment of Izala movement was to purify Islam from all innovations. For several years, the Izala movement attacked Sufism on this matter, but it was also a struggle over interpretative authority in Islamic issues and as such directly linked to questions of power. After the division of the movement the discourse on bid'a became part of the internal struggle of the movement. One interesting finding of this study is that the organization that was established to fight innovations found itself within the same discourse fighting an "internal bid'a".

The re-implementation of shari'a was a project for all Muslims and all Islamic groups were invited to take part in it. The Izala movement has had to cooperate with other Muslim organizations despite their religious orientation - even with Sufis. Shari'a re-implementation was positively perceived by the Izala movement; furthermore; many Izala leaders claim to have been the driving force behind the project. This could be interpreted as a new orientation of the organization from attacking Sufis to cooperating with them as part of the whole shari' $a$-project. This was necessary for the movement in order to overcome its own problems and regain more space and prestige among Muslims.

The field of shari'a generally and that of the Izala movement specifically is complex and multifaceted. In fact, the religious field cannot be separated from the political. The motivation of Nigerian politicians to re-implement Islamic law was manifold: it could have been part of a political campaign to collect as many votes as possible; it might even have been out of religious zeal or simply because the masses demanded it. However, politicians needed religious actors to achieve their goals. Islamic scholars are thus the major actors in this study. The Muslim community of Nigeria holds Islamic 
scholars in very high esteem. They enjoy high social prestige and have influence over society. To become an Islamic scholar is a great deal of work, and necessitates particular skills and intensive knowledge. Apart from memorizing the Qur'ann, studying the tradition of the Prophet, knowing Arabic (as a holy language), and mastering the most important sources of the Islamic tradition, Islamic scholars must also attend a university, obtain an academic degree, and travel abroad to seek knowledge. Along the way, they generally build useful personal networks. Preaching, writing books, participating in ongoing discourses and providing access to the sources are the ways to achieve social recognition.

The struggle for "symbolic power" among Islamic scholars in Nigerian religious and political fields is stronger now than it has ever been. The Izala movement did not "miss the boat" because they were able to read the writing on the wall and learned to understand the "rules of the game." Consequently, the Izala movement changed their former strategy of direct confrontation. The new "religious field" in which the Izala movement was operating necessitates adjustment to the new dynamics of the field(s). This adjustment was prescribed by an intensive competition with other groups. The Izala movement accommodated itself to the necessity of the time: it became a protector of the sunna at the local level and for those who followed its doctrine. At the same time, the movement was part of the Muslim umma and the shari'a project. By being part of these, the Izala movement moved within the religious field but was also able to negotiate the political field in the north, which was characterized by an ongoing struggle for space, power, and acknowledgement. Through "invading" the religious and political field, the Izala movement had to make an offer in the "religious market" of Nigeria.

In discussing the history of the Izala movement, most of its leaders narrate a victorious event that depicts the triumph of the founder, Sheikh Ismaila Idris (1937-2000) over the Sufis and even over the Nigerian state. Being an individual aware of the situation of Muslims in his country, Sheikh Idris started his da'wa by preaching the oneness of God. Before he restricted his activities to preaching, he was an imām in the Nigerian army. The growth of a movement around Sheikh Idris at its initial stage influenced him to think of an official organization that protects him and his followers from Sufi attacks and state confrontation. The registration of the Izala movement in 1978 was not possible due to vigorous opposition. Therefore, it took place only in 1985. Until that time, the Izala movement acted under the umbrella of a different Islamic organization, namely the Jamāeat Naṣr al-Islām (in Arabic: Society for the Victory of Islam; JNI).

The Izala movement is autonomous when it comes to financial resources. The leader(s) of the movement developed a three-tiered structure for the organization: the local, the state, and the national levels. At every stage, there is a council of 'ulamä', an administrative unit, and First Aid Groups. To sponsor its projects, the Izala movement relies mainly on donations from its members and supporters at all levels. This is a strategy initiated by the founder. To show the effectiveness of the Izala movement 
in collecting donations, the Jos branch of the Izala movement collected 10,924,296 Naira (approximately 50,000 Euro) and 665 bags of grain in 2009 through the newly established zakatt-board. ${ }^{345}$ The philosophy of the Izala movement is to take the initiative itself before waiting for any other assistance.

When it comes to education, the Izala leadership is proud to mention its achievements in that sector. The organization realized that educating people is an effective way to propogate its doctrine. The Izala movement initiated nursery, primary, and secondary schools. The Izala movement also maintains Saturday and Sunday schools. According to their own sources, the number of schools is 5,191 with more than 3.4 million students. They also have a diploma section with three branches in Jos, Bauchi, and Gombe. ${ }^{346}$ Most (if not all) schools are registered, and programs and examinations are under the supervision of the Ahmadu Bello University, Zaria. The education of women is an important part of the Izala educational project. Members of movement are invited to permit their wives to go to schools. Educated women are asked to teach their relatives and neighbors. This strategy succeeded in such a way that many Izala movement schools today are attended by small girls and married women. One of my interviewees says proudly: "We even pushed traditional Sufis to send their wives to schools."

The last aspect of the "offer" the Izala introduced is the fact that they attracted many Sufi followers who left their tariqa and joined the movement. The Izala movement stands for tawhid, and for combating witchcraft and innovation. Their organization has branches in all thirty-six Nigerian states. They even propagate their doctrines in neighboring countries (Republic of Niger, Chad, Cameroon, and even Sudan). ${ }^{347}$

In the mid-1980s, the Izala movement suffered from an internal crisis on the level of leadership and subsequently split into two factions, Jos and Kaduna. This development can be explained by problems associated with guiding the organization as well as monetary matters. Through this division, the attitude towards Sufism changed. When asked about the reasons for the division, the Jos and Kaduna-factions will give different answers. Sheikh Ali Abdallah, member of the council of 'ulama's' in the Kadunafaction explains that money and struggle for leadership divided the movement.

In sum, the Izala movement succeeded in establishing itself as an organization propagating the oneness of God and inviting people to come back to the religion of Islam on the basis of the Qur'ān, sunna, and the tradition of the pious predecessors. Izala movement leaders themselves claim the failure of the movement to unify all Muslims. It failed because of its style of leadership and harsh attitude towards others. Money issues and theological differences led to the division of the movement. In absence

\footnotetext{
${ }^{345}$ Interview with Sheikh Jingir published at http://www.peoplesdaily-online.com/index.php/news/ education/55-education/ of 3 December 2009 (deactivated, please contact Göttingen University Press for a record).

346 Ibid.

${ }^{347}$ In several Interviews, the leaders of the Jos faction confirmed having branches in all Nigerian states. As part of that, Izala movement is also active in neighboring countries (Republic of Niger, Chad, Cameroon, Ghana, and even Sudan (see Umar 2001: 127-150).
} 
of any reliable statistics on the approximate number of Izala followers, the number of members of the movement is not known. To become a member of the Izala movement or leave the organization is possible at any time. Registration is not required but loyalty plays a crucial rule.

If we come back to the definition of religious organizations offered by Stark and Bainbridge (1980: 114-128), we read: "Religious organisations are social enterprises whose primary purpose is to create, maintain, and exchange supernaturally-based general compensators." In this context, Izala movement as a religious "firm" offers a way of achieving the reward of Allah and as a means of reaching al-janna (paradise). The organization claims to have the best access to Islamic sources and invites adherents to follow its path. The Izala movement is also aware of the "religious market" in Nigeria. As an organization, it struggles not only inside the Muslim community but also outside. Competition against other Islamic organizations is required. What the Izala movement is offering is their brand of Islam identified with authenticity and purity of religion. The organization is exclusive to those who accept its offer. What makes it attractive to people is its efficiency and its obvious credibility in establishing schools, mosques, and hospitals. Also, the strictness of the Izala movement in defining religion played a crucial role in giving it an identity among Muslims. Izala movement (especially in Jos) are known as hardliners and if we apply the model suggested by Introvigne for Turkey, the Izala movement belongs to the category "strict". Of course, this emphasis can be discussed and may be revised in the Izala context. ${ }^{348}$

The strictness of the founder of the Izala movement and the 'ulamä'surrounding him made the organization attractive to people. As proof of success, the actual leader of the Jos faction says: "Our records speak for us" (Shaykh Sani Yahya Jingir, 22 December 2006). But that same strictness and attachment to a particular doctrine led to the division of the movement. Several attempts to unify the different factions failed. As we have seen, the Izala movement is divided into two "firms." The first one is in Jos, related to the founder and his doctrine. To attract more followers this firm developed the strategy claiming that they are more authentic. The second group is established in Kaduna and is convinced that the division was necessary to save the organization's initial and authentic goals.

The level of success of the Izala movement can be measured in accordance with the model suggested by Stark. In this context, he proposed a number of arguments for a religious movement to be successful (see Stark 1996: 133ff): first, the Izala movement seems to be successful in retaining "cultural continuity with the conventional faith." The Izala movement is also a continuation of the project of purification of Islam initiated by Sheikh Gumi and Sheikh Idris. The movement sees itself as the ideal protector

\footnotetext{
348 The model developed for Turkey by Introvigne (2005) includes five different "niches" (ultra-strict, strict, moderate-conservative, liberal and ultra-liberal). This is problematic for the Izala movement context although the organization aligns with his category "strict". Surprisingly in the same category we find Sufis as well as Wahhabis.
} 
of the sunna and it places itself within the tradition of pious predecessors that goes back to the first centuries of Islam.

Second, Stark assumes that new religious movements can be successful to the extent that their doctrines are non-empirical. Stark gave the example of the Jehovah's Witnesses who "suffered very marked decline in missionary activity" after their expectation of the end of the world did not take place. The point here is that a successful religious movement has a non-empirical doctrine. In fact, this can also be proved for the Izala movement case. I showed earlier that bid'a or innovation is an "open system of meanings." Fighting innovation in Islam and establishing the sunna are the two elements of Izala doctrine. The Izala movement offers a unique way to achieve reward in the afterlife. This dogma cannot be proven empirically.

Third, religious movements succeed according to Stark if they maintain a medium level of tension with their surrounding environment- they are strict but not too strict. Indeed, the Izala movement maintained a moderate level of tension with its surrounding environment. The movement opposes, for example, wearing amulets and justifies this by claiming that such a practice does not exist in the fundamental sources of Islam. Yet, Izala do not oppose non-Izala attending their schools at different levels of education. This illustrates the moderate aspect of strictness of the movement as mentioned above.

Fourth, legitimate leaders of religious movements have adequate authority according to Stark. This statement requires clear doctrinal justification and that participants recognize themselves as members of this system of authority. In the case of the Izala movement, this assumption does not apply due to the fact that the movement was divided into two factions. The leadership of Sheikh Idris seems not to have been effective enough so that it could be recognized by all Izala members. In fact, many Izala members questioned the legitimacy of his leadership and formed another group with a new authority and more "legitimate" leaders.

Fifth, religious movements can generate a highly motivated, volunteer religious force willing to proselytize. This statement is absolutely applicable to the Izala movement. Members of the movement are highly motivated. Their activities and contributions within the movement are not paid. Each member considers himself an Izala representative who can transmit its message and propagate its doctrine.

Sixth, the level of fertility that offset the level of mortality required for any religious movement to survive. This point can also be identified in the Izala movement since it produced and still produces leaders and members able to guarantee the continuation of the movement's doctrine.

Seventh, Rodney Stark assumes that religious movements prosper so that they compete against weak, local religious organizations within a relatively unregulated religious market. This can be empirically shown again when looking at the Izala movement. Since its establishment in 1978, the Izala movement has been competing with other Muslim groups in northern Nigeria. This competition has led to the recognition of the Izala movement as part of the religious landscape. The Izala movement rejects 
ignorance about Islam and ask Muslims to intensify their knowledge in this field. The Izala movement invites people to reject any affiliation with Sufism and to join the movement's struggle for a "purified" Islam. By doing that, the Izala movement is in a continuous competition for legitimacy with other Muslim groups.

Eighth, new religious movements will succeed - according to Stark - to the extent that they sustain strong attachments, while remaining an open social network which is able to maintain and form ties with outsiders. This proposition by Stark can also be affirmed in the Izala context. The Izala movement offers a religious and social service to its followers. At the same time, the Izala movement is an open social network. Its goal is to bring newcomers, "converts" non-Muslims, and integrate them into its doctrine. The Izala movement also maintain "bonds" of networks to non-Izala movement. This happens either through education (at schools receiving pupils from different groups and orientations) or through social interaction with other Muslims/non-Muslims. This openness is necessary for the movement to be attractive to outsiders.

Ninth, according to Stark a religious movement continues to grow so that it can maintain sufficient tension with its environment. This is again applicable to the Izala movement, since the movement maintains a certain level of strictness towards other groups. The level of strictness has decreased since the first years of the establishment until today. The movement still defines its own identity and religious orientation, but seems to be more accomodating to others. This can be a seen as a way of adaptation to the necessities of the religious environment in northern Nigeria.

Finally, a religious movement has to socialize with the young sufficiently well as to minimize both defection and the appeal of reduced strictness. In fact, youth are the target of the Izala movement. The movement promotes a particular type of education at Izala movement schools. These schools and institutions are known for high levels of competition. Graduates especially recognize the Izala's strictness of achieving its goal of establishing an Islamic education based on the Qur'ān and sunna and far away for any innovation. The Izala movement is known - even by outsiders of the movement by its strictness in achieving goals.

Rodney Stark developed these arguments for the analysis of any religious movement willing to achieve a certain level of success. At the same time, he expects failure of any religious movement for varying reasons, like division or the appearance of new leadership with new ideas or approaches related to authenticity. Stark argues that most religious movements share one aspect which he called "eventual failure". In fact, the Izala movement faced this failure when it was divided into two major groups during the life time of its founder, Sheikh Idris. For many years, the conflicting Izala parties struggled over legitimacy and authenticity. Both sides kept the same name and the same structure and continued preaching to people in the name of the "authentic" Izala movement that calls Muslims to the right path of Islam. Surprisingly, the Izala movement managed to reunite in $2011 .{ }^{349}$ This event confirms Stark's theory that failure remains "eventual".

349 I did not conduct research on the reunification of the movement in 2011. I accomplished my PhD 
Several aspects of the "modes of religiosity theory" (see introductory chapter) introduced by Whitehouse can be proven in the Izala context. The two basic elements of his theory (remembering and motivation) are part of Izala's doctrine. The Izala movement insists on revivalism of the sunna of the Prophet. This revival should happen via studying this tradition and making it an indispensable part of the daily religious routine. The organization offers easy access to this tradition: it proposes the relevant Qur'ānic verses and hadith quotations. It produces books and preaches to the adherents. The Izala movement has developed its own educational curricula according to its needs. Having this ideology repeated to adherents in schools, mosques, media, writings, CDs, and audio-cassettes, the doctrine can be preserved indefinitely. The motivation of Izala members (like any Muslims) is to achieve the reward of Allah. These elements can also be found in the context of Sufi brotherhoods insisting on the survival of their sheiks and their tariqa. Memorization is part of their doctrine and daily repetition of litanies keeps this doctrine alive. Members of Sufi groups have the same motivation (reward, paradise) as Izala movement, but differ in their methods for reaching such a goal.

Whitehouse gives two types of religious modes: a doctrinal and an imaginistic one. All aspects of the doctrinal mode of religiosity are identifiable in the Izala movement as well as among Sufi-groups (rituals, long-term-episodic memory, religious leaders, hierarchy, and orthodoxy). The initial assumption that Sufism may be categorized under the imagistic mode of religiosity can be disproved. Sufi brotherhoods like any other Islamic groups experienced reform(s). Among the practices in Sufism that were rarely performed, imaginistic modes of religiosity became part of the doctrine itself. The use of drums (bandiri) was introduced by late Sheikh Nasiru Kabara, the Qàdiriyya leader in Kano, and became a crucial element in the Qaddiriyya-doctrine. ${ }^{350}$ Two crucial aspects proposed by Whitehouse when it comes to imagistic modes of religiosity are: low frequency and high emotional arousal. This assumption can be rightfully observed during celebrations like the birthday of the Prophet or that of the tariqa founder Sheikh 'Abd al-Qādir al-Jilānī. These celebrations take place once a year and are widely distinguished with a lot of emotions. Nevertheless, the theory can be contradicted by the fact that the daily and weekly practices of Sufis are performed frequently with high emotional arousal. Tijānīs recite their litanies (Arabic: awräd) twice a day. They participate daily in so-called wazi îfa, or congregational recitation of a Tijānī formula. Also, the followers of the Qàdiriyya organize the so called hadra (in Arabic: congregational ritual) and dbikr either on Thursdays or Fridays. The use of drums and the repetition of religious songs either in the zäwiya or in the mosque go together with a very high level of emotion.

project before that event took place. The reunification after many years of division may be an interesting topic for future research on the Izala movement. On this issue see Loimeier (2016) and Thurston (2016).

${ }^{350}$ For the bandiri performance in mosques by the Qādiriyya see Larkin (2004: 91-112) as well as Buba and Furniss (1999: 27-46). 
Whitehouse identifies "emotional bonds between participants" (Whitehouse 2002: 307) that resulted from the high emotional arousal in the context of the imagistic mode. In fact, these "emotional bonds" can be observed on a daily basis during the congregational meetings of Sufis. Due to the fact that any religious practice can be a place for showing emotions and be used for distanciation from other groups, it is possible to argue that these emotions are related to the doctrinal conflict between Sufis and the Izala movement. During my fieldwork, I observed indeed that Sufis organize from time to time walima (in Arabic: gatherings like marriage or birth). In many cases, this is accompanied with food and celebrations. The Izala movement group also initiated such a walima as an answer to the Sufi brotherhoods. The Izala movement makes a point to only recite the Qur'ann. This is also a way to show high emotions and distance from Sufi practices.

To conclude this text, I would like to stress the fact that the theoretical and conceptual models regarding religious dynamics as represented by Whitehouse, Stark and Bourdieu have not yet been tested so far in an "Islamic" context. In this respect, the present text represents an effort to translate Whitehouse, Stark and Bourdieu into the northern Nigerian context and to see whether their arguments work here as well. It has to be kept in mind, however, that "no condition is permanent," as Nigerians never tire to stress. Thus, the future development of religious reform movements such as the Izala will show whether theoretical models that try to explain religious change have to be adapted accordingly or if they have a degree of analytical power that is sufficient to also explain future development. 



\section{Bibliography}

Abdallah, Dalha Abubakar (n.d.). al-radd wa'l-nașing (The Answer and Advice). Abdulkadir, Muhammed Safiyyu (2006). A Literary Survey of Arabic Sermons of J.I.B.W.I.S. in Bauchi Metropolis. Bauchi State, MA-dissertation in Arabic, University of Jos, Nigeria.

Abun-Nasr, Jamil M. (1965). The Tijaniyyah. Oxford: Oxford University Press. (1993a). Muslime im Nationalstaat Nigeria, in: Abun-Nasr, Jamil M. (ed.). Muslime in Nigeria: Religion und Gesellschaft im politischen Wandel seit den 50er Jahren. Münster, Hamburg: Lit-Verlag, 1-40.

- (1993b). Islamisches Recht im nigerianischen Rechtssystem, in: Abun-Nasr, Jamil (ed.). Muslime in Nigeria: Religion und Gesellschaft im politischen Wandel seit den 50er Jabren. Münster, Hamburg: Lit-Verlag, 201-225.

— (2007). Muslim Communities of Grace: The Sufi Brotherhoods in Islamic Religious Life. London: Hurst \& Company.

Abdallah, Jamila Adam (2005). The Role ofJ.I.B.W.I.S in the Development of Arabic and Islamic Culture in Jos. BA-dissertation in Arabic Studies, University of Jos, Nigeria.

Adesoji, Abimbola (2010). The Boko Haram Uprising and Islamic Revivalism in Nigeria, in: Africa Spectrum 45, 2, 95-108. 
Alburnawi, Ali Mustafa Abubakar (1990). Risāla ilā al-ikhwān al-muslimīn fil-radd 'alā qawl al-sheikh al-munharif' an al-kitāb wa-l-sunna (Letter to Muslim Brothers as an Answer to the Sheikh who Deviated from the Sunna). Maiduguri.

Algar, Hamid (2002). Wabhabism: A Critical Essay. Oneonta, New York: Islamic Publications International.

Alhassan, Idris A. (2003). The Role of School of Higher Islamic Studies Sarkin Mangu Jos in Advancing the Spread of Islamic Culture, and Arabic Language for the Year 1989 to the Year 2001. BA-dissertation in Arabic Studies, University of Jos, Nigeria.

Alidou, Husseina D. (2005). Engaging Modernity. Muslim Women and the Politics of Agency in Postcolonial Niger. Madison: The University of Wisconsin Press.

Aliyu, Tamimu (n.d.). Ignantaccen Taribin Jama'atu Izala til Bid'ab Wa'Ikamatis Sunnah. Jos: Abdulazeez Printing Co.

Anwar, Auwalu (1989). Struggle for Influence and Identity. The 'ulamä' in Kano, 1937-1989. M.A. Thesis (History), University of Maiduguri, Nigeria.

Babaji, B. and Dankofa, Y. (2003). Assessing the Performance of Lower Courts in the Implementation of Shari'a Penal Law and Justice System in Northern Nigeria, in: J. N. Ezeilo, M. T. Ladan and A. A. Afolabi-Akiyode (eds.). Sharia Implementation in Nigeria. Enugu: Women's Aid Collective, 103-127.

Bala, Muhammad G. and Muhammad Sani Umar (2001). Religion and the Pan-African Ideal: The Experience of Salafi Islam in the West African Sub-Region, in: African Journal of International Affairs, 5, 2, 141-160.

Batran, Abd al-Aziz Abd-Allah (1973). A Contribution of the Biography of Sheikh Muhammad ('Umar-Amar) al-Maghīlī al-Tilimsānī, in: Journal of African History, 14, 381-394.

Bello, Ahmad (2008). The Role of Jama'at at-Tajdid al-Islami and Its Role in Spreading the Arabic and Islamic Culture in Bauchi. BA-Dissertation in Arabic Studies, Ahmadu Bello University.

Ben Amara, Ramzi (2005). Die Entwicklung der Šarīa-Frage in Nigeria Ende der 1990 er Jabre. MA-thesis in Religious Studies, University of Bayreuth.

Bossaller, Anke (2004). 'Schlafende Schwangerschaft' in islamischen Gesellschaften. Entstebung und soziale Implikationen einer weiblichen Fiktion. Würzburg: Ergon Verlag.

Bourdieu, Pierre (1977). Outline of a Theory of Practice. Cambridge: Cambridge University Press.

_ (1986). The Forms of Capital, in: Richardson, John (ed.): Handbook of Theory and Research for the Sociology of Education. New York: Greenwood Press, 241-258.

Brigaglia, Andrea (2001). The Fayda Tijāniyya of Ibrahim Nyass: Genesis and Implications of a Sufi Doctrine, in: Islam et Sociétés au Sud du Sabara, 14/15, 41-56. 
- (2004). Testo, tradizione e conflitto esegetico: gli 'ulamä' contemporanei e gli sviluppi dell'esegesi coranica nella società nord-nigeriana (Kano e Kaduna), 1960-2002. Ph.D. dissertation, Università degli Studi di Napoli "L'Orientale".

(2005). Two Published Hausa Translations of the Qur'ān and Their Doctrinal Background, in: Journal of Religion in Africa, 35, 4, 424-449.

- (2007). The Radio Kaduna 'Tafsīr' (1978-1992) and the Construction of Public Images of Muslim Scholars in the Nigerian Media, in: Journal for Islamic Studies, 27, 173-210.

_ (2012a). Ja far Mahmoud Adam, Mohammed Yusuf and Al-Muntada Islamic Trust: Reflections on the Genesis of the Boko Haram Phenomenon in Nigeria, in: Annual Review of Islam in Africa, 11, 35-44.

_ (2012b). A Contribution to the History of the Wahhābī Dáwa in West Africa: The Career and the Murder of Shaykh Ja'far Mahmoud Adam (Daura, ca. 1961/1962-Kano 2007), in: Islamic Africa, 3, 1, 1-23.

Buba, Malami and Graham Furniss (1999). Youth Culture, bandiri, and the Continuing Legitimacy Debate in Sokoto Town, in: Journal of African Cultural Studies, 12, 1, 27-46.

Bunza, Umar Mukhtar (2005). The North African Factor in tajdeed Tradition in Hausaland, Northern Nigeria, in: The Journal of North African Studies 10, 3/4, 325-338.

Charlick, Robert B. (2004). Islamism in West Africa: Niger, in: African Studies Review 47, 2, 97-107.

Chaumont, E. (1995). Al-salaf wa'l-khalaf, in: The Encyclopaedia of Islam, $2^{\text {nd }}$ edition, Leiden: Brill, vol.8, 900.

Christelow, Allen (2002). Persistence and Transformation in the Politics of Sharia, Nigeria, 1958-2002: In Search of an Explanatory Framework. Paper presented at the Conference on Muslim Law in Post-Colonial Africa. Centre for Contemporary Islam, University of Cape Town, 11-14 March 2002.

Clarke, Peter (1988). Islamic Reform in Contemporary Nigeria: Methods and Aims, in: Third World Quarterly 10, 2, 519-538.

Connolly, Peter (ed., 1999). Approaches to the Study of Religion. London and New York: Cassell.

Constitution of the Federal Republic of Nigeria (1999). Lagos: Federal Government Press.

Cook, Michael (1992). On the Origins of Wahhabism, in: Journal of the Royal Asiatic Society, Series 3 (2), 191-202.

Crowder, Michael (1964). Indirect Rule: French and British Style, in: Africa: Journal of the International African Institute, 34, 3, 197-205.

Dan Fodio, Usman (n.d.). Ibyä al-sunna wa-ikbmād al-bid'a (Revival of the Sunna and Upheaval of Innovation). Al-Fikr-Distribution. N.p. 
Danfulani, Umar H. D. (2005). The Sharia Issue and Christian-Muslim Relations in Contemporary Nigeria. Stockholm: Almqvist \& Wiksel International.

—, Ludwig, F. and P. Ostien (2002). The Sharia Controversy and Christian-Muslim Relations in Nigeria, in: Jabrbuch für kontextuelle Theologien, Frankfurt/ London, 70-95.

Echtler, Magnus (2008). Changing Rituals - The New Year's Festival in Makunduchi, Zanzibar, since Colonial Times. PhD thesis, University of Bayreuth.

El Baradie, Adel (1983): Gottes-Recht und Menschenrecht. Grundlagen der islamischen Strafrechtslebre, Baden-Baden: Nomos.

El-Masri, F.H. (1963). The Life of Shehu Usman Dan Fodio before the jibād, in: Journal of The Historical Society of Nigeria, 2, 4, 435-448.

Engler, Steven (2003). Modern Time: Religion, Consecration and the State in Bourdieu, in: Cultural Studies 17, 3/4, 445-467.

Falola, Toyin (1998). Violence in Nigeria: The Crisis of Religious Politics and Secular Ideologies. Rochester NY: University of Rochester Press. (1999). The History of Nigeria. Westport: Greenwood Press.

and M. Heaton (2008). History of Nigeria. Cambridge: Cambridge University Press.

Fatunde, Tunde (2000). Nigerias Rückkehr zur Demokratie. Eine Bewertung, in: KAS-AI/00, 74-76.

Fierro, Maribel (1992). The Treatises against Innovations (kutub al-bida), in: Der Islam 69, 204-246.

Forstner, Martin (1987) Der Islam in der westafrikanischen Sahel-Zone. Erscheinungsbild - Geschichte - Wirkung. In: Zeitschrift für Missionswissenschaft und Religionswissenschaft 71 (1987). 25-84, 97-120.

Fwatshak, Sati U. (2003). Sharia Enforcement in Northern Nigeria: The Hisba and the Publics. Paper Presented at the Conference on "The Sharia Debate and the Shaping of Muslim and Christian Identities in Northern Nigeria”. Bayreuth, 11-12 July 2003, 1-23.

Gerhard, Tobias (2010). Counter-Discourse in Global News Media? How Aljazeera English Covers Sectarian Violence in Nigeria. MA thesis, Central European University, Department of International Relations and European Studies, Budapest.

Ghazali, Abdullahi (n.d.): Maliki Law: The Predominant Muslim Law in Nigeria, http://www.gamji.com/article4000/NEWS4601.htm (21/05/2011).

Goldziher, Ignác (1890/1971). Muhammadanische Studien II. Hildesheim: Georg Olms Verlag.

Grégoire, Emmanuel (1993). Islam and Identity of Merchants in Maradi (Niger), in: Louis Brenner (ed.). Muslim identity and social change in Sub-Sabaran Africa. London: Hurst, 106-115.

Gumi, Abubakar (1972). Al-'aqida al-sabịha bi-muwäfiqah al-sharía (The Right Belief Is Based on the Sharīa a). Ankara: Hilal Yayinlari. 
with I. A. Tsiga (1992). Where I Stand. Ibadan: Spectrum Books.

Gurama, Muhammad Nuhu (2000). Leadership Tussles in an Islamic Organization: A Case Study of the Jamā'at Izala Movement Al-Bid'ah Wa Iqamat Al-Sunnab (J.I.B.W.I.S.). MA-Dissertation in Islamic Studies, University of Jos, Nigeria.

Gurum, H.M. and A.M. Bello (2005). Like Father Like Son? Dr. Gumi's Misconception, in: JIBWIS Journal, 21-22.

Gwarzo, Tahir Haliru (2006). Islamic Civil Society Associations and the State: A Kano State Case Study 1994-2004. PhD in Political Science, Bayero University, Kano, Nigeria.

Gwarzo, Hassan Ibrahim (1972). The Life and Teachings of Al-Maghili with Particular Reference to the Saharan Jewish Community. PhD, SOAS, London.

Hackett, Rosalind (2011). Millennial and Apocalyptic Movements in Africa. From Neo-Traditional to Neo-Pentecostals, in: Wessinger, Catherine (ed.): The Oxford Handbook of Millennialism. New York: Oxford University Press, 616-674.

Harbom, Lotta and Peter Wallensteen (2010). Armed Conflict 1946-2009, in: Journal of Peace Research, 47, 4, 501-509.

Higazi, Adam (2007). Violence Urbaine et Politique à Jos (Nigeria), de la Période Coloniale aux Élections de 2007, in: Politique Africaine 106, 69-91.

Hill, Jonathan N. C. (2010). Sufism in Northern Nigeria: Force for Counter-radicalization? https://archive.org/details/SufismInNorthernNigeriaAForceForCoun ter-radicalization, 1-65.

Hiskett, Mervyn (1980). The Maitatsine Riots in Kano, 1980: An Assessment, in: Journal of Religion in Africa, 17, 3, 209-223.

Hock, Klaus (1996). Der Islam Komplex. Hamburg: Lit Verlag.

Hunwick, John (1974). Al-Maghili's Replies to the Questions of Askia al-Hajj Mubammad, ed. and transl. with an Introduction on the History of Islam in the Niger Bend to 1500. Brit. Thesis Service, Betchworth. London, Univ. Dissertation.

- (2005). Islamic Revival in Africa: Historical and Contemporary Perspectives, in: Kamari Maxine Clarke (ed): Local practices, Global controversies: Islam in Sub-Sabaran African Contexts, The Macmillan Center, Yale, 25-44.

al-Husseini, Ibrahim Saleh (1986/2003). Al-mughìr 'alà shububāti abl al-abwā waakadbīb al-munkir 'alā kitāb al-takfìr. Beirut: Al-Maktaba al-Ibrāhīmiyya.

- (2005). Al-durar al-lammä'a fi-baqiagati ma'na abl al-sunna wa'l-jamä́a (The Shiny Pearls in the Real Meaning of People of the Sunna the Community), unpublished manuscript.

Ibrahim, B. Yusuf (2003). Application of the Sharia Penal Law and Justice System in Northern Nigeria: Constitutional Issues and Implications, in: Ezeilo, J. Ngosi, Ladan, M. Tawfiq and A. Afolabi-Akiyode (eds.): Sharia Implementation in Nigeria: Issues and Challenges on Women's Rights and Access to Justice. Enugu/ 
Port Hartcourt/Abuja: WACOL; Lagos: WARDC, Heinrich Böll Foundation, $128-137$.

Ibrahim, Jibrin (2002). Democracy and Minority Rights in Nigeria: Religion, Shari’a and the 1999 Constitution. Paper for the Conference on „Globalisation, State Capacity and Self-Determination in Muslim Contexts“. Centre for Global, International and Regional Studies, University of California-Santa Cruz, Santa Cruz, 7-10 March 2002, https://web.archive.org/web/20070119020224/ http://www.ucsc.edu/cgirs/conferences/carnegie/papers/ibrahim.pdf

Ikime, Obaro (1970). The Establishment of Indirect Rule in Northern Nigeria, in: Tarikh, 3 (Indirect Rule in British Africa), Historical Society of Nigeria, 1-15.

Inalc1k, Halil (1995). Resm, in: The Encyclopaedia of Islam. $2^{\text {nd }}$ New Edition. Leiden: Brill, vol. 8, 486-487.

Introvigne, Massimo (2005). Niches in the Islamic Religious Market and Fundamentalism: Examples from Turkey and Other Countries, in: Interdisciplinary Journal of Research on Religion, 1, 1, 1-23.

Isichei, Elizabeth (1983). A History of Nigeria. New York: Longman Group Limited. (1987). The Maitatsine Risings in Nigeria 1980-85: A Revolt of the Disinherited, in: Journal of Religion in Africa, 17, 3, 194-208.

Izala Movement Kaduna Draft of Constitution (1995), unpublished document. Jallo, Muhammad Ibrahim (n.d.). Risalātān maftuhatāni ilā zāìm al-jamāáa alismäiliyya, ash-Sheikh Sani Yabya Jingir (Two Open Letters to the Leader of the Jamāáa al-Ismā̄îliyya, Sheikh Sani Yahya Jingir).

JIBWIS (n.d.). al-Jama'a fi Sutür (The Organization in a Few Lines). National Headquarters, Jos: Abdulazeez Printing Press Ltd.

Jingir, Muhammadu Sani Yahya (2006): Tawjīh a-l-Tālib ilà 'Ibādat Allab 'Ibadatan wa Mu'amala (Guidance of the Student to the Oneness of God in the Context of Worshipping and Religious Transactions), Jos: JIBWIS-Headquarters.

Kaba, Lansine (1972). Evolution of Islam in West Africa, the contribution to political Islam 1945-58. PhD-Thesis, Northwestern University, Evanston/Illinois.

Kabara, Qaribullah Nasiru (n.d.). al-Mir'āt al-șāfiya fi-bayāni ḅaqiqqat al-tașawwuf wa-ba'di rijālibi dhawì al-maqāmāt al-'aliya. Kano: Darul Qādiriyya Publications.

Kalu, Ogbu (2003). Safiyya and Adamah: Punishing Adultery with Sharia Stones in Twenty-first-century Nigeria, in: African Affairs, 102, 408, 389-408.

Kane, Ousmane (1993). Les mouvements islamiques et le champ politique au nord du Nigeria: le cas du mouvement Izala movement à Kano. Thèse de doctorat, IEP, Paris.

- (1994). Izala Movement: The Rise of Muslim Reformism in Northern Nigeria, in: Martin E. Marty and R. Scott Appleby (eds.), Accounting for Fundamentalisms: The Dynamic Character of Movements. Chicago: University of Chicago Press, 490-512. 
- (1999). La polémique contre le soufisme et les ordres soufis en Afrique de l'Ouest post-coloniale, in: Frederick de Jong \& Bernd Radtke (eds.), Islamic Mysticism Contested: Thirteen Centuries of Controversies and Polemics, Leiden: Brill, 324-340. (2003). Muslim Modernity in Postcolonial Nigeria: A Study of the Society for Removal of Innovation and Reinstatement of Tradition. Leiden: Brill.

Kogelmann, Franz (2006). The "Sharia Factor" in Nigeria's 2003 Elections, in: Benjamin F. Soares (ed.). Muslim-Christian Encounters in Africa. Leiden: Brill, 256-274.

Kramer, Robert S. (2009). Mahdi, in: Esposito, John (ed.): The Oxford Encyclopedia of the Islamic World, Oxford: Oxford University Press, 448-450.

Lamaison, Pierre (1986). From Rules to Strategies: An Interview with Pierre Bourdieu, in: Cultural Antbropology, 1, 110-120.

Larkin, Brian (2004). Bandiri Music, Globalization, and Urban Experience in Nigeria, in: Social Text, 22, 4, 91-112.

Last, Murray (1967). The Sokoto Caliphate. London: Longman Group Limited.

Lawal Adam, Abdurrahman (1992). The Conflict Between the Jama'atu Izala Movementtil Bid'ah Waiqamatis Sunnah (JIBWIS) and the Sufi Orders in Jos and the Stand of Jama'atu Nasril Islam (J.N.I.). MA-Dissertation, University of Jos, Nigeria.

Layish, Aharon (2004). The Transformation of the Sharīe from Jurists' Law to Statutory Law in the Contemporary Muslim World, in: Die Welt des Islams, $44,1,85-113$.

Lewis, Bernard (1953). Some Observations of the Significance of Heresy in the History of Islam, in: Studia Islamica 1, 43-63.

Loimeier, Roman (1988). Das Nigerian Pilgrimage Scheme, in: Afrika Spectrum, 23, 2, 201-14.

(1992). Die Dynamik religiöser Unruhen in Nord-Nigeria, in: Africa Spectrum, $27,1,59-80$.

(1993). Islamische Erneuerung und politischer Wandel in Nordnigeria - Die Auseinandersetzungen zwischen den Sufi-Bruderschaften und ihren Gegnern seit Ende der 50er Jahre, LIT: Hamburg.

_ (1997a). Islamic Reform and Political Change in Nigeria. Evanston: Northwestern University Press.

- (1997b). Die radikale islamische Opposition in Nordnigeria, in: Afrika Spectrum, 32, 1, 5-23.

- (1997c). Islamic Reform and Political Change: The Example of Abubakar Gumi and the 'Yan Izala Movement in Northern Nigeria, in: David Westerlund (ed.). African Islam and Islam in Africa. Encounters between Sufis and Islamists. London: Hurst, 286-307.

- (2003). Patterns and Peculiarities of Islamic Reform in Africa, in: Journal of Religion in Africa, 33, 3, 237-262. 
- (2005). De la dynamique locale des réformismes musulmans. Études biographiques (Sénégal, Nigeria et Afrique de l'Est), in: M. Gomez-Perez (ed). L'Islam politique au sud du Sabara. Identités, discours et enjeux. Paris: Karthala, 29-48.

— (2007). "Yesu Hakusulubiwa -Jesus wurde nicht gekreuzigt": Möglichkeiten und Grenzen des Vergleichs religiöser Reformbewegungen. Paper presented at the University of Leipzig, 11/10/2007.

- (2012). Boko Haram: The Development of a Militant Religious Movement in Nigeria, in: Africa Spectrum, 47, 2-3, 137-155.

- (2016). Islamic Reform in 20th Century Africa. Edinburgh. Edinburgh University Press.

Lubeck Paul M. (1985). Islamic Protest under Semi-Industrial Capitalism: 'Yan Tatsine Explained, in: Africa: Journal of the International African Institute, 55, 4, 369-389.

Ludwig, Frieder (2001). Religion und Politik im Kontext multireligiöser afrikanischer Staaten am Beispiel Nigerias, In: Walter Beltz und Jürgen Tubach (eds.): Religiöser Text und soziale Struktur, Hallesche Beiträge zur Orientwissenschaft, 31, 249-269.

- (2008). Christian-Muslim Relations in Northern Nigeria since the Introduction of Shari'ah in 1999, in: Journal of the Academy of Religion, 76, 3, 602-637.

Lugard, Lord Frederick D. (1965). The Dual Mandate in British Tropical Africa. London: Frank Cass \& Co. Ltd.

MacDonald, D. B. (1913). „Bid‘““, in: Enzyklopädie des Islam, Leiden: Brill, 742-3. Maier, Karl (2000). This House has fallen. Nigeria in Crisis. London: Penguin Books. Makinde, Abdul-Fatah (2007). The Institution of Shari ${ }^{-}$ah in Oyo and Osun States, Nigeria, 1890-2005. PhD-Thesis in Arabic and Islamic Studies, University of Ibadan, Nigeria, http://www.sharia-in-africa.net/media/publications/theinstitution-of-sharia-in-oyo-and-osun-states-nigeria/makinde-thesis.pdf

Masquelier, Adeline M. (1996). Identity, Alterity and Ambiguity in a Nigerien Community: Competing Definitions of 'True' Islam, in: Richard Werbner and Terence Ranger (eds.), Postcolonial Identities in Africa. London: Zed Books, 222-244.

(1999). Debating Muslims, Disputed Practices: Struggles for the Realization of an Alternative Moral Order in Niger, in: Jean Comaroff and John L. Comaroff (eds.): Civil Society and the Political Imagination in Africa: Critical Perspectives. Chicago: University of Chicago Press, 219-250.

- (2009). Women and Islamic Revival in a West African Town. Bloomington: Indiana University Press.

Meunier, Oliver (1997). Les Routes de L'Islam. Antbropologie politique de l'islamisation de l'Afrique de l'Ouest en général et du pays hawsa en particulier du $8^{\text {ème }}$ au $19^{\text {ime }}$ siècle. Paris: Editions L'Harmattan. 
- (1998a). Marabouts et courants religieux en pays hawsa: dynamique de l'islamisation de la ville de Maradi à la fin du $\mathrm{XIX}^{\circ}$ siècle et durant le $\mathrm{XX}^{\circ}$ siècle, in: Revue Canadienne d'Études Africaines 32, 3, 521-557.

_ (1998b). Les voies de l'islam au Niger dans le Katsina independant du XIX e au $X X^{e}$ siècle. Paris: Publications Scientifiques du Museum.

Mohammed, Danladi A. (2002). Muslim Intellectuals and the Sharia Debate in Nigeria, https://web.archive.org/web/20101120032532/http://www.niger deltacongress.com/marticles/muslim_intellectuals_and_the_sha.htm (1 June 2019).

Muhammad Anka, Bawa D. (2002). Izalah-Tariqah Relationship in Zamfara: A Study in Perspective. MA-Dissertation in Islamic Studies, Usman Dan Fodio University Sokoto, Nigeria.

Muhammed, Sadis Muhammed (2001). Late Sheikh Ismaila Idris Bin Zakariyya His Contribution to the Development of Jama'atu Izala Movementtil Bid'a Wa Iqamatis Sunnah (J.I.B.W.I.S.) in Nigeria. BA-dissertation in Islamic Studies, University of Jos, Nigeria.

al-Munjid fi-l-lugha w-al-A làm (1986). Beyrouth: Dar al-Mashreq.

Murtaza, Muhammad Sameer (2005). Die Salafiya, die Reformer des Islam: eine Darstellung der Biographien und des politischen Denkens von Gamal Al-Din Al-Afgani, Mubammad Abduh, Mubammad Rasid Rida und Hasan AlBanna, sowie der Muslimbruderschaft in ibrer formativen Phase 1928-1932. Nordersted.

O’Brien, Susan M. (2007). La Charia contestée: Démocratie, débat et diversité musulmane dans les 'état Charia' du Nigeria, in: Politique Africaine 106, 46-68.

Oba, A. A. (2002). Islamic Law as customary Law: the Changing Perspective in Nigeria, in: International and Comparative Law Quarterly, 51, 4, 817-850.

Oduyoye, Modupe (2000). The Shariy'ah Debate in Nigeria. October 1999 - October 2000. Ibadan: Sefer.

Ogbondah, Chris W. (2000). Political Repression in Nigeria, 1993-1998: A Critical Examination of One Aspect of the Perils of Military Dictatorship, in: Africa Spectrum 35, 2, 231-242.

Olayiwola, Abdulfattah O. A. (1997). The polytomy of Islam in Nigeria-Emanation, implication, and possible rectification. PhD-thesis at the School of Postgraduate Studies, Islamic Studies, Department of Religious Studies, University of Jos, Nigeria.

Onuoha, Freedom C. (2010). The Islamist challenge: Nigeria's Boko Haram crisis explained, in: African Security Review, 19, 2, 54-67.

Ostien, Philip (2006). An Opportunity missed by Nigeria's Christians: The 1976-78 Sharia Debate revisited, in: Soares, E. Benjamin (ed.): Muslim-Christian Encounters in Africa. Leiden: Brill, 221-255.

_- (ed., 2007). Sharia Implementation in Northern Nigeria 1999-2006: A Sourcebook. Ibadan: Spectrum Books Limited. 
- (2009). Jonah Jang and the Jasawa: Ethno-Religious Conflict in Jos, Nigeria, in: Muslim-Christian Relations in Africa, 1-44.

J. M. Nasir and F. Kogelmann (eds., 2005). Comparative Perspectives on Shariah in Nigeria. Ibadan: Spectrum Books.

— and Albert Dekker (2010). Sharia and National Law in Nigeria, in: Otto, Jan Michiel (ed.): Sharia Incorporated: A Comparative Overview of the Legal Systems of Twelve Muslim Countries in Past and Present. Leiden: Leiden University Press, 553-612.

Paden, John (1986). Abmadu Bello. Sardauna of Sokoto. Zaria: Hudahuda Publishing Company.

- (1973). Religion and Political Culture in Kano. Berkeley: University of California Press.

Peters, R. (2003). Islamic Criminal Law in Nigeria. Ibadan, Nigeria: Spectrum Books.

Post, Jerrold M. (1986): Narcissism and the Charismatic Leader-Follower Relationship, In: Political Psychology, 7, 4, 675-688.

Qadri, Yasir (1981). The Tijanniyyah in Nigeria: A Case Study. Ibadan: University of Ibadan.

Ramadan, Tariq (2009). Radical Reform: Islamic Ethics and Liberation. Oxford: Oxford University Press.

— ([2007] 2016) In the West. First Attempts at Reform. 6 Parts (First published 2007 as On the Concept of Reform at http://www.tariqramadan.com). https:// tariqramadan.com/english/in-the-west-first-attempts-at-reform-16/; ...-26/; ...-36/; ...-46/; ...-56/; ...-66/ (1.11.2019).

Reynolds, Jonathan T. (1999). The Time of Politics (Zamanin Siyasa). Islam and the Politics of Legitimacy in Northern Nigeria 1950-1966. San Francisco: International Scholars Publications.

- (2001). God and bad Muslims. Islam and Indirect Rule in Northern Nigeria, in: The International Journal of African Historical Studies, 3-4, 3, 601-618.

Rigachikun, Yusufu Muhammad Sambo (2005). Ayyukan Majalisar Malamai Da Siffofin Mai Wa'azi Da Manifofin Kungiyar J.I.B.W.I.S Ta Kasa. Kaduna: Al-Amana Printing Press.

Robson, J. (1960). Bid'a, in: The Encyclopaedia of Islam. $2^{\text {nd }}$ New Edition. Leiden: Brill, vol. 1, 1199.

Rosander, Eva Evers and David Westerlund (1997). African Islam and Islam in Africa. Encounters between Sufis and Islamists. Athens: Ohio University Press.

Saleh, Idris Muhammad (2006). kalimāt wajīza li-qam'sharr al-ḥasūd (Short Words to Overwhelm Envious People's Evil), 13 ${ }^{\text {th }}$ January.

Sani, Abul-Mumin (1994). The Image and Legacy of Late Sheikh Abubakar Mahmud Gumi. Unpubl. BA-Dissertation, Islamic Studies, University of Jos, Nigeria. 
Sanneh, Lamin (2003). Shariáah Sanctions as Secular Grace? A Nigerian Islamic Debate and an Intellectual Response, in: Transformation, 20/4, 232-244.

Sanusi L. Sanusi (1999). Issues in Constructing Corporate Nigeria. Paper Presented at the "National Conference on the 1999 Constitution", organized by the Network For Justice and The Vision Trust Foundation, Arewa House, Kaduna, 11-12 September 1999.

— (2002). The Hudood Punishment in the Northern Nigeria: A Muslim Criticism. Unpublished paper, prepared for a publication. ISIM NEWS, the quarterly publication of the Institute for the Study of Islam in Modernity. Leiden.

- (2004). The West and the Rest: Reflections on the Intercultural Dialogue about Shari'ah. Paper presented in the Conference on „Comparative Perspectives on Shari'ah in Nigeria“, Bauchi Road Campus, University of Jos, 15-17 January 2004.

- (n.d.). On the Islamization of Politics and the Politicization of Islam, http:// www.gamji.com/sanusi/sanusi14.htm (22 December 2004).

Schulze, Reinhard (1990). Islamischer Internationalismus im 20. Jabrbundert. Untersuchungen zur Islamischem Weltliga. Leiden: Brill.

Seesemann, Rüdiger (2004). Nach der „Flut“: Ibrābìm Niasse (1900-1975), Sufik und Gesellschaft in Westafrika. Habilitationsschrift, University of Bayreuth.

- (2011). The Divine Flood: Ibrabim Niasse and the Roots of a Twentieth-century Sufi Revival. Oxford: Oxford University Press.

Shehu, Balarabe I. (2001). The Light of Truth. Kano: Gidan Dabiro Publisher.

Sodiq, Yushau (1992). A History of Islamic Law in Nigeria: Past and Present, in: Islamic Studies, 31, 1, 85-108.

Spickard, James V. (1998). Rethinking Religious Social Action: What Is "Rational" about Rational Choice Theory? In: Sociology of Religion, 59, 2, 99-115.

Sounaye, Abdoulaye (2009). Izala movement au Niger: une alternative de communauté religieuse, in: L. Fourchard, O. Goerg and M. Gomez-Perez (ed.): Les lieux de sociabilité urbaine dans la longue durée en Afrique. Paris: L'Harmattan, 481-500.

Stark, Rodney (1996). Why Religious Movements Succeed or Fail: A Revised General Model, in: Journal of Contemporary Religion, 11, 2, 133-146.

— and W. S. Bainbridge (1980). Towards a Theory of Religion: Religious Commitment, in: Journal for the Scientific Study of Religion, 19, 2, 114-128.

- and R. Finke (2000). Acts of Faith: Explaining the Human Side of Religion. Berkeley: University of California Press.

Sulaiman, Muhammad Dahiru (1993). Shiaism and the Islamic Movement in Nigeria 1979-1991, in: Islam et sociétés au Sud du Sabara, 7, 5-16.

Suleiman, G. Ibrahim (2005). Mallam Ibrabim El-Zakzaky and the Question of Shi'ism. B.A.-Dissertation in Islamic Studies, University of Jos, Nigeria.

Swartz, David (1996). Bridging the Study of Culture and Religion: Pierre Bourdieu's Political Economy of Symbolic Power, in: Sociology of Religion, 57, 1, 71-85. 
Tabiu, Muhammed (2001). Sharia, Federalism and Nigerian Constitution. Paper presented at the International Conference "Restoration of Sharia in Nigeria: Challenges and Benefits“, 14 April 2001, organised by the Nigerian Muslim Forum, London.

Tal, Madina L. (1991). Un Islam militant en Afrique de l'Ouest au XIXe siècle: La Tijāniyya de Saiku Umar Futiyu contre les pouvoirs traditionnels et la puissance colonial. Paris: L'Harmattan.

Talbi, Mohammed (1960). Les bid'a, in: Studia Islamica, 12, 43-77.

Taschner, Barbara (2006). Die Scharia in Nigeria anhand der Texte von Sanusi Lamidu Sanusi. BA-Thesis, Religious Studies, University of Bayreuth, Germany.

The Constitution of the Jama'tu Izalatil Bid'ah Wa'Ikamatis Sunna ([2004]). Unpublished document.

The JIBWIS Journal (2005): Jos: Jos Headquarters, Sarkin Mangu, 1, 3.

Thurston, Alexander (2016). Salafism in Nigeria: Islam, Preaching and Politics. Cambridge: Cambridge University Press.

- (2018). Boko Haram: The History of an African Jibadist Movement. Princeton: Princeton University Press.

Triaud, Jean-Louis and David Robinson (eds., 2000). La Tijâniyya: Une confrérie musulmane à la conquête de l'Afrique. Paris: Karthala.

Umar, Muhammad Sani (1983). Islamic Revivalism Today.The Example of Jama'tu Izaltul Bid'ah Wa Iqamitis Sunnah, BA-Thesis, Jos University.

(1988). Sufism and Anti-Sufism in Nigeria. MA-Thesis, University of Kano.

(1993). Changing Muslim Identity in Nigeria from the 1960s to the 1980s:

From Sufism to Anti-Sufism, in Brenner, Louis (ed.). Muslim Identity and

Social Change in Sub-Sabaran Africa, Bloomington: Indiana University Press, $154-178$.

- (2001). Education and Islamic Trends in Northern Nigeria: 1970s-1990s, in: Africa Today, 48 (2), 127-150.

Wakili, Haruna (2009). Islam and the Political Arena in Nigeria: The ulamä' and the 2007 Elections. ISITA Working Paper No. 09-004.

Weimann, Gunnar J. (2010). Islamic Criminal Law in Northern Nigeria. Politics, Religion, Judicial Practice. PhD-thesis, University of Amsterdam.

Whaling, Frank (ed., 1995). Theory and Methods in Religious Studies. Contemporary Approaches to the Study of Religion. Berlin and New York: Mouton de Gruyter.

Whitehouse, Harvey (2002). 'Modes of Religiosity: A Cognitive Explanation of the Sociopolitical Dynamics of Religion', in: Method and Theory in the Study of Religion, 14, 293-315.

- (2004). Modes of Religiosity: A Cognitive Theory of Religious Transmission. Walnut Creek, CA: Alta Mira Press. 
World Bank (1996). Report No. 14733-UNI Nigeria Poverty in the Midst of Plenty. The Challenge of Growth with Inclusion. World Bank Poverty Assessment, May 311996.

Yandaki, A. Isyaku (1990). A History of the Izala Movement in Northern Nigeria up to 1989. MA-Dissertation, University of Sokoto, Nigeria.

Yadudu, Auwalu Hamisu (1988), We Need a New Legal System in: Ibrahim Suleiman and Siraj Abdulkarim (eds.). On the Future of Nigeria, Zaria: Hudahuda Publishing and Co., 2-7.

Yassari, Nadjma (2004). Islamisches Recht oder Recht der Muslime - Gedanken zu Recht und Religion im Islam, in: Zeitschrift für Vergleichende Rechtswissenschaften, 103, 103-121.

Yusufari, Mamman Lawan (2004): Sharia Implementation in Kano State, http:// www.gamji.com/article3000/NEWS3706.htm (7 October 2004).

al-Zakzaky, Ibraheem (1999). Application of Shariah in the Contemporary World: Lessons from some Muslim Countries. Paper presented to the national Conference on the Application of Shariah organised by the Department of Islamic Law. Faculty of law, Bayero University and RAMNAN Law Consult, Kano, Bayero University, 1-3 December 1999. 
O $\mathrm{n}$ the basis on solid fieldwork in northern Nigeria including participant observation, interviews with Izala, Sufis, and religion experts, and collection of unpublished material related to Izala, three aspects of the development of Izala past and present are analysed: its split, its relationship to Sufis, and its perception of sharīa re-implementation. "Field Theory" of Pierre Bourdieu, "Religious Market Theory" of Rodney Start, and "Modes of Religiosity Theory" of Harvey Whitehouse are theoretical tools of understanding the religious landscape of northern Nigeria and the dynamics of Islamic movements and groups.

Since October 2015 Ramzi Ben Amara is assistant professor (maître-assistant) at the Faculté des Lettres et des Sciences Humaines, Sousse, Tunisia. Since 2014 he was coordinator of the DAAD-projects "Tunisia in Transition", "The Maghreb in Transition", and "Inception of an MA in African Studies". Furthermore, he is teaching Anthropology and African Studies at the Centre of Anthropology of the same institution. His research interests include Islam in Africa, Sufism, Reform movements, Religious Activism, and Islamic law. 